\title{
Judicial Treaty Federalism and the Reconciliation of Ontario's Duty to Consult
}

By

Charles M. Garay

A thesis submitted to the Faculty of Graduate and Postdoctoral Affairs

In partial fulfillment of the requirements for the degree of

Doctor of Philosophy in Public Policy

\author{
Carleton University \\ Ottawa, Ontario, Canada
}

(C) 2021

Charles M. Garay 


\section{$\underline{\text { Abstract }}$}

This dissertation examines the role of the Canadian judiciary as a bridge between Indigenous and settler legal traditions, and the ability of common law jurisprudence to frame the recognition of Indigenous sovereignty by settler governments. Focusing particularly on First Nation consultation policies in the province of Ontario, it is asked whether these policies incorporate judicial language on the Crown's "duty to consult and accommodate" on matters affecting recognized or asserted Aboriginal and treaty rights. These legal duties impose limits to the exercise of Crown sovereignty in Indigenous territories, and the manner in which these principles are implemented in the policy process imply different understandings of treaty law and the sources of sovereignty at the root of Canadian federalism.

This research describes the relationship between courts and legislatures as a dialogue, and looks to late $19^{\text {th }}$ and early $20^{\text {th }}$-century decisions of the Judicial Committee of the Privy Council for previous examples where appellate courts have altered the distribution of sovereignty between provincial and federal governments. This logic can then be reapplied in an Indigenous context, where the addition of Section 35 to the Constitution Act, 1982 provided a legal link between treaty law and the Canadian constitution. The failure of subsequent political conferences to further define the content of Section 35 increased the importance of judicial interpretation. The role of judges in interpreting a body of law which both has constitutional status and exists outside the main constitutional document is described as "judicial treaty federalism", incorporating elements of "treaty federalism" in Canadian political science literature and "judicial federalism" in American literature.

Following an examination of key Supreme Court cases relating to the duty to consult and accommodate, and the role of provincial Crowns in its application, this dissertation examines current legislation and consultation policy in Ontario for adherence to these legal principles. Semi-structured interviews with both provincial civil servants and representatives of rightsholding First Nations in Ontario also provide insight into how these principles have been implemented. This research concludes that while a common law framework exists for the recognition of Indigenous legal orders, this recognition has not permeated the policymaking process in Ontario. A decentralized approach to consultation, poor communication and aspecific guidance both within government and with Indigenous communities, and the Crown's continued unilateral rights assessment are all major contributors to this discrepancy between law and policy. Political negotiation and policy change will be necessary to close this gap, but individual public servants can also adopt certain changes to everyday practice which can improve CrownIndigenous relations until policies reflecting shared sovereignty can be implemented. 


\section{$\underline{\text { Acknowledgements }}$}

I am deeply indebted to many people in the completion of this research, and their contributions have only reinforced the notion that a dissertation is anything but an individual project. First and foremost, I would like to thank my supervisor, Professor Frances Abele, for her insight, wisdom, patience, empathy, and steadfastness throughout this process. Her advice and guidance has had a lasting impact on my thinking, and for that I am deeply grateful.

I would also like to thank my committee members, Professors David Newhouse and Heather Dorries. They have introduced me to new and important perspectives within the academy, and their keen perception has challenged me to be more thorough in my arguments.

Additionally, I would like to thank Professor Katherine Graham for her good humour and support throughout my years with the Indigenous Policy and Administration program at Carleton. In working alongside her, I have made connections with incredible leaders in Indigenous Canada, and I've had the pleasure of watching students become community and policy leaders in their own right.

I am deeply grateful as well for the Ontario civil servants and First Nation leaders who took the time to speak with me about their work, and the successes and pitfalls along the way. I had the pleasure of speaking to leaders from the Algonquins of Pikwakanagan First Nation, the Anishinabek Nation, the Windigo First Nations Council, the Mohawk Council of Akwesasne, and the Curve Lake First Nation; as well as from the Ontario Ministries of Indigenous Affairs, Health, Transportation, Energy, and Natural Resources and Forestry. Our conversations were candid, and their insights brought life both to provincial policy and ongoing treaty relationships. I hope that these are only the first of many more conversations to come.

As well, I would like to thank my family - my parents, Andrew Garay and Ruth Rutherford, and my siter, Olivia Garay - and many other friends who have all encouraged, supported, distracted, and teased me in equal measure. Their love and companionship has seen me through many hard days.

Finally, this dissertation is dedicated to the love of my life, my fiancée Justine TrotterSheppard, who introduced herself one night at a house party and has never left my side since. Her love, her laughter, and her belief in me have been constants these last three years; and as I close this chapter in my life, I'm filled with joy in thinking about the new chapters we'll write together. 


\section{Table of Contents}

Abstract

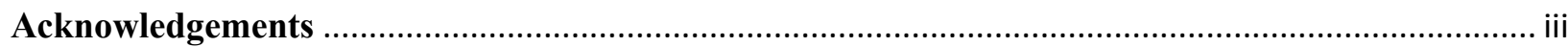

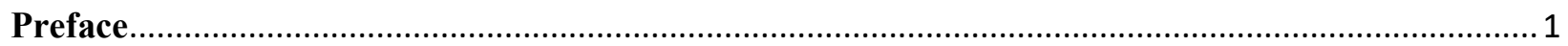

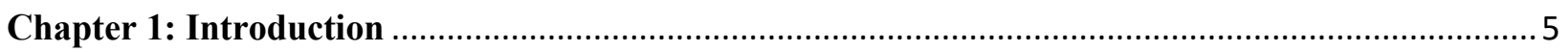

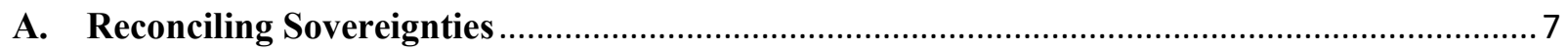

B. Canadian Federalism and the Indigenous Order ........................................................... 15

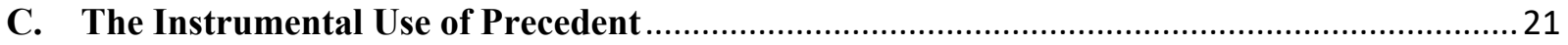

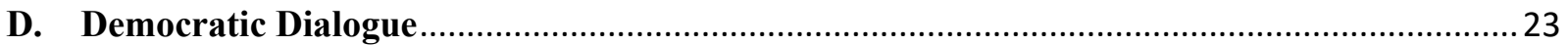

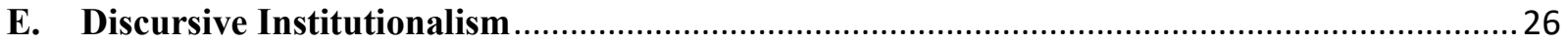

F. The Indigenous Order and Ontario: Outlining the Research................................................29

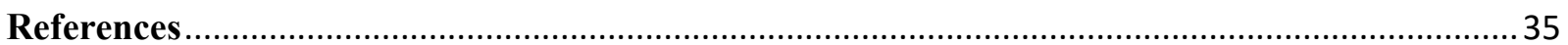

Chapter 2: Federalism Literature and the Emergence of Judicial Treaty Federalism .....................41

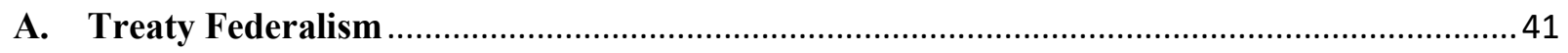

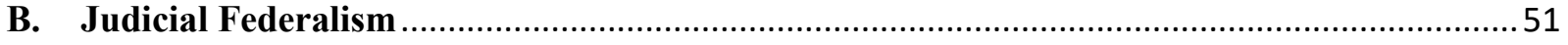

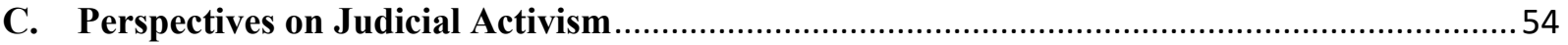

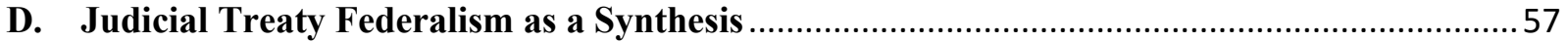

E. Caveats to the Recognition of Indigenous Sovereignty Through Common Law ...................60

F. Linking Judicial Treaty Federalism with Consultation Policy ….........................................64

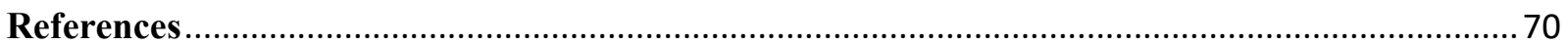

Chapter 3: The History and Legacy of Compact Theory........................................................... 74

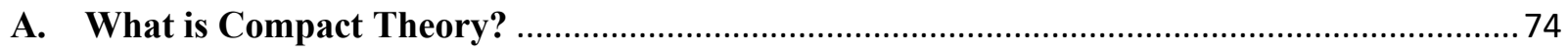

B. The JCPC and the British North America Act …............................................................... 78

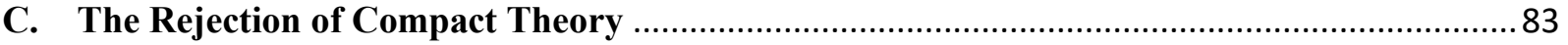

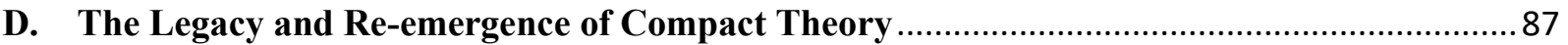

E. The Crown-Indigenous Compact and Patriation ................................................................. 92

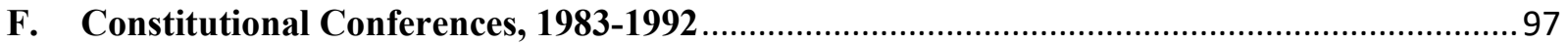

G. The Risks of Defining Constitutional Rights..................................................................... 103

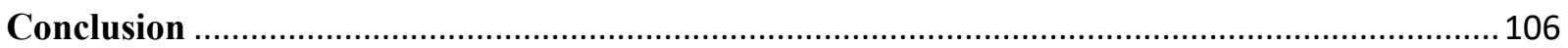

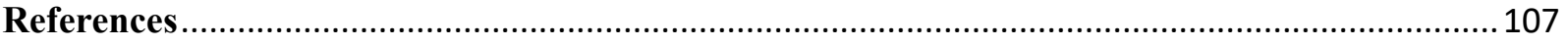

Chapter 4: Outlining the Duty to Consult \& Accommodate - Haida Nation and Taku River .........110

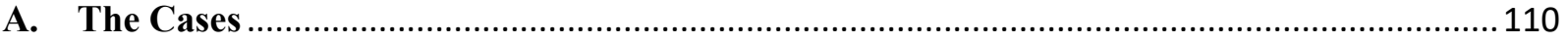

i. $\quad$ Haida Nation v. B.C. (Minister of Forests) ............................................................................ 110 
ii. Taku River Tlingit First Nation v. B.C.

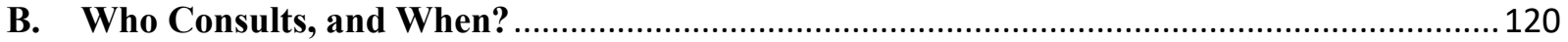

C. Accommodation, Consent, and Reconciliation ............................................................... 124

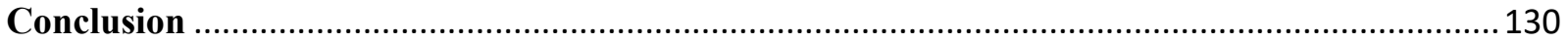

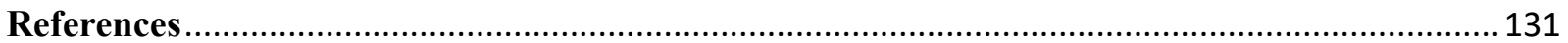

Chapter 5: Applying the Duty to Consult \& Accommodate to Provincial Policy Roles................... 133

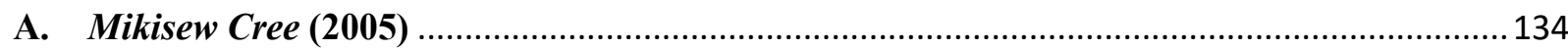

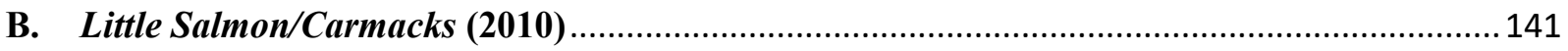

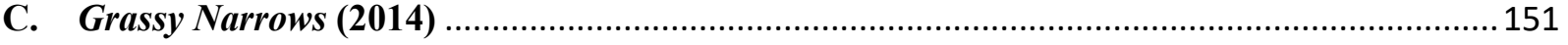

D. The Relevance of Tsilhqot'in to the Grassy Narrows Decision.............................................157

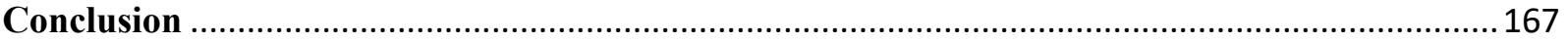

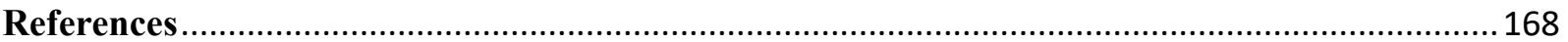

Chapter 6: Implementing Consultation Policy in Ontario and the Federal Leadership Role .........170

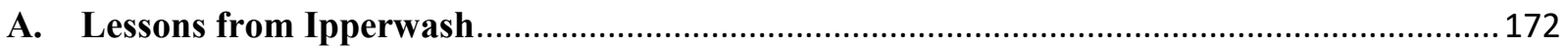

B. The Duty to Consult in Ontario Legislation .................................................................... 176

C. The Duty to Consult in Ontario Policy .......................................................................... 179

D. Interviews on the Implementation of Ontario's Duty to Consult ..........................................201

E. A Snapshot of Consultation in Other Canadian Provinces and Territories .........................224

F. The State of Federal Leadership in Crown-Indigenous Partnership .................................230

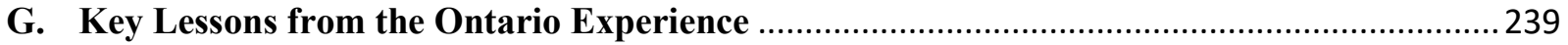

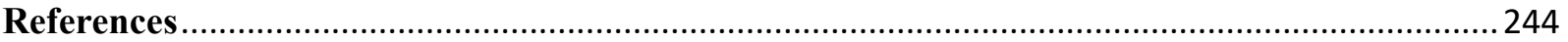

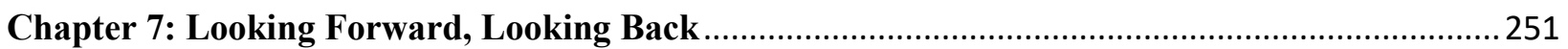

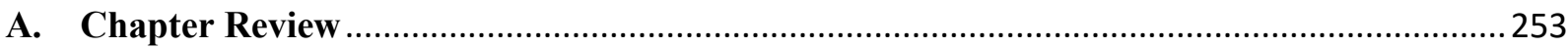

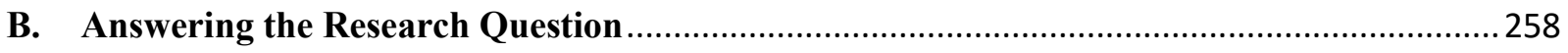

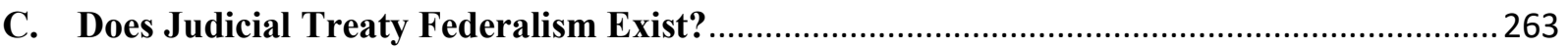

D. General Rules for Effective Consultation Relationships ..................................................266

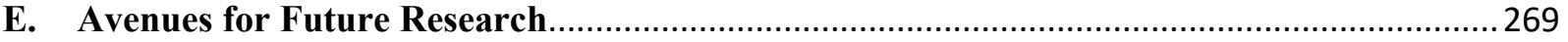

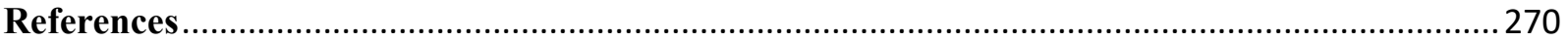

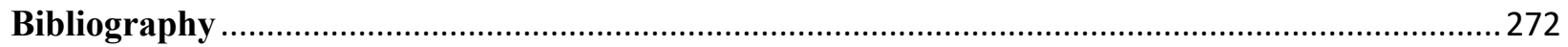

Appendix A: Sections 91 and 92, British North America Act, 1867 .................................................283

Appendix B: Questionnaires Used in Semi-Structured Interviews ...........................................285

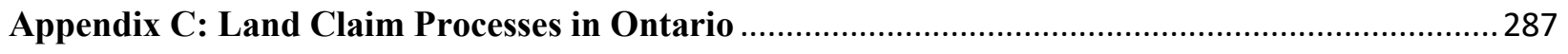

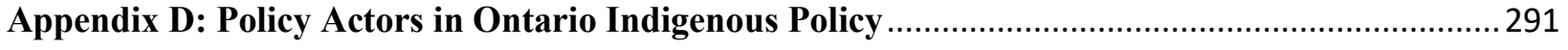




\section{$\underline{\text { Preface }}$}

In the course of working on this dissertation I have learned a number of important lessons from the First Nations people who have generously shared their time with me. One such lesson is that public conversations frequently begin by telling those assembled your name, who your people are, and where you're from. The reason for this is twofold. First, declaring who you are is declaring a set of temporal relationships - relationships to your community, relationships to your audience, and a relationship to your topic. (Wilson 2008) Second, locating yourself in this way dispenses with the notion that research can be entirely objective. (Absolon and Willett 2004) Your perception of your topic and interpretation of the evidence is coloured by personal history, and this history is coloured by the set of relationships you carry with you. With this in mind, it is important that I make a similar declaration at the outset, so that readers may better understand my position and what biases I may or may not bring to the table.

I am a settler ${ }^{1}$ of Hungarian Jewish, Irish, and English origin raised predominantly in Toronto, Canada. I stumbled into the world of Indigenous policy as a masters student when I helped organize a conference on Indigenous governance. I came away from the experience feeling that there was a hidden history in this country of which I knew next to nothing. Like many non-Indigenous Canadians, I could not understand the Crown-Indigenous relationship, nor could I understand the magnitude of the cultural genocide that was carried out in Canada's name, because I had simply never been told.

Since the Report of the Truth and Reconciliation Commission of Canada was published in 2015 there has been much talk of "reconciliation" in Canadian public discourse, and this

\footnotetext{
${ }^{1}$ By "settler" I mean a non-Indigenous Canadian, irrespective of when they or their ancestors settled in Canada.
} 
dissertation is no exception. Reconciliation means many things to many people, with varying levels of commitment attached. Most Canadians have never set foot in an Indigenous community, so how can they come to understand what reconciliation implies? The responsibility for educating all Canadians about their history cannot be placed exclusively on the shoulders of Indigenous peoples. Governments, institutions, and private citizens alike must educate themselves on the treaty relationship; on the promise at the basis of Confederation, and how that promise has been broken.

The beginning of such education requires, first and foremost, establishing shared terminology. The words "Indigenous" and "Aboriginal" are both employed extensively in this dissertation, and though they are similar they are not interchangeable. "Indigenous" is the term currently favoured by original peoples, and is most frequently employed in international law, such as the United Nations Declaration of the Rights of Indigenous Peoples. It has increasingly come to replace the word "Aboriginal", which now lives on in Canadian constitutional law through Section 35 of the Constitution Act, 1982. Section 35, in turn, distinguishes between the three main "Aboriginal peoples of Canada", these being First Nations, Inuit, and Métis, each of whom have different relational histories with the Crown. For the purposes of this research "Indigenous rights", for instance, refers to inherent rights stemming from ancestral occupation, whereas "Aboriginal rights" refers to rights interpreted through the lens of common law.

To whom is this dissertation addressed? As a policy study, it is fundamentally directed at policymakers working in provincial and federal governments moreso than the general Canadian populace. These settler governments have grandfathered in a set of colonial institutions from their imperial past, and a new generation of public servants must once again ask whether they 
will continue the cycle of colonial governance, or work to decolonize their own institutions so that they better reflect the original intent of the Crown-Indigenous compact. (see Dorries 2012, 166) Understanding treaty relationships and treaty law has major implications for policy practice, and following the extensive legal study presented herein, the final conclusions of this research are drawn from implementation and practice.

The history of colonization is Canadian history, as much a part of the story of nonIndigenous Canada as it is for Indigenous Canada. (Milloy 1999. xvii-xix) Contemporary Canada, and particularly the children of recent immigrants, may feel that they have little part in this colonial legacy, since they had no hand in crafting the colonial regime. That being said, there is a responsibility to challenge the continuation of this regime if it is no longer in keeping with the values of Canadian society. Indigenous peoples have naturally been at the forefront of this challenge, and governments have a duty to listen and understand (Davis and Hiller, n.d.; Finch 2012).

Indigenous activists have frequently mobilized their claims through the court system and, crucially, through constitutional law. These claims are not always successful, but when they are these cases become signposts on the road to renewed Crown-Indigenous relationships. Some commentators have criticized this method, arguing that Canadian courts will never question the basis of the Crown sovereignty upon which their authority rests. But they can help with envisioning how to share power. Mobilizing Indigenous understandings through settler courts also has the advantage of making these understandings comprehensible to non-Indigenous Canadians who know little of Indigenous laws, but who respect the legal reasoning of the courts. (Walters 2006, 501; Dorries 2012, 143; see also McNeil 2019) Understanding the law that grounds the treaty relationship between Indigenous people and the Canadian Crown makes us 
better partners in a renewed relationship, (Institute of Public Administration of Canada 2017)

because it reminds us of the unique rights Indigenous nations hold, and of our original promise to uphold those rights.

Despite knowing the harm that the settler state has caused, I remain hopeful about Canada. Canada is a country that has always had pluralism and compromise at its core. What has changed significantly over generations is who is included in that pluralistic vision. At the time of John A. Macdonald, Canada was a compact between British and French, Protestant and Catholic, with little or no room for others. Even that limited compact often proved shaky and uncertain. A century later, when the Pearson government convened the Royal Commission on Bilingualism and Biculturalism, testimony from Ukrainian-Canadians, Chinese-Canadians and others forced citizens to consider that this was a country not of two founding nations, but many.

Canada has distinct political cultures, distinct regions, and multiple systems of law already incorporated within it. Why should public governments be unable to widen the circle to include Indigenous nations? Arguably, it is the failure to recognize Indigenous governance rights that creates political risk. It leads to litigation, protest, policy uncertainty, and the continuation of human rights abuses. Recognition paves the way for agreement, and a navigable and predictable policy landscape. But that unfinished work of Confederation still remains. Treaties embody a constitutional compact now "recognized and affirmed" under Section 35(1) of the Constitution Act, 1982 and yet non-Indigenous governments still need to recognize the distinct, Indigenous order of government that has been in front of them the entire time. 


\section{Chapter 1: Introduction}

In the summer of 2015, the Truth and Reconciliation Commission of Canada (TRC) released its final report, and brought the concept of "reconciliation" to the forefront of public consciousness. The 94 Calls to Action outlined therein called upon every segment of Canadian society - from governments to private citizens, from public institutions to private industry - to take steps to reconcile the principles and practices of Canadian society with the existence and pre-existence of Indigenous societies. The current federal Liberal government of Justin Trudeau has repeatedly and publicly committed to implementing the TRC's 94 Calls to Action, and to get the ball rolling on what will almost certainly be a generational project, requiring a fundamental reimaging of the nature of Canadian federalism.

The Calls to Action issued by the TRC of great importance to this research. Of particular relevance are the calls for mutual recognition and the repudiation of terra nullius (CTA 45, 46, and 47), the publishing of legal opinions on treaty rights (CTA 51), governments bearing the burden of proof when asserting title to traditional lands (CTA 52), the education of public servants on Aboriginal rights (CTA 57), the furtherance of research on reconciliation (CTA 65), and obtaining the informed consent of Indigenous peoples on development projects (CTA 92(1)). ("Honouring the Truth, Reconciling for the Future: Summary of the Final Report of the Truth and Reconciliation Commission of Canada" 2015)

By examining the settler side of the reconciliation project, this research explores the ways in which the Supreme Court has framed the settler recognition of Indigenous sovereignty, and how that understanding is borne out in Ontario's First Nation consultation policies. 
Understanding both the legal framing of the Indigenous constitutional order, and the manner in which that frame is implemented ought to show public servants that denying Indigenous rights, title, and jurisdiction is both in violation of constitutional law and presents major policy risk. Implementing a policy agenda without a roadmap for good faith negotiation can lead to relitigating settled matters of Aboriginal rights law. Negotiations are costly and time-consuming, but remain less costly and time-consuming than fighting losing battles in the courts. Fostering relationships of mutual respect and mutual recognition is not only a practical reality in a pluralistic country, it is also the right thing to do.

This chapter examines how reconciliation should be understood in the context of Indigenous sovereignty, and how the legal pluralism which the Canadian constitution already embodies must be widened to include Indigenous polities. Indigenous nations and governance traditions have survived ongoing attempts by settler governments to erase them, and in recent decades this resilience has been expressed through Canadian constitutional law. This chapter presents opening arguments for how the judiciary has translated Indigenous understandings of the treaty relationship into the common law and provided new legal discourse with which federal and provincial governments have had to contend. Giving this legal terminology the force of law has produced a "discursive institutionalism", to borrow a phrase from political scientist Vivien Schmidt, and precipitated a "democratic dialogue" - a sort of call and response between courts and legislatures. This dissertation uses Ontario's provincial policies on the duty to consult and accommodate First Nations as a case study within its examination of Canadian federalism. The chapter closes with an overview of how subsequent chapters will provide the evidence for judicial influence in provincial consultation policy. 


\section{A. Reconciling Sovereignties}

Post-Patriation ${ }^{2}$ legal scholarship has increasingly painted a judicial vision of legal pluralism. This approach to the settler recognition of Indigenous sovereignty can be seen in a 2012 lecture by the late Justice Lance Finch of the BC Court of Appeal. In it, Justice Finch posits that Canada is a multi-jural nation, meaning that our legal traditions are drawn from common, civil, and Indigenous law. (see also Slattery 1996) As such, Justice Finch argues that jurists have a "duty to learn" about Indigenous history and legal traditions, and to be self-aware about the Eurocentric bias of the common law. He argues:

Present Canadian society must find a way to exist together with a pre-existing cultural landscape. Similarly, in the purely legal context, we must find ways to achieve reconciliation by finding space for the Canadian legal order within the pre-existing legal landscape.

In other words, the task for which we are attempting to equip ourselves is not only that of making space within the known landscape, [...] it is a matter of attempting, in good faith, and as respectfully as possible, to enter new landscapes: legal, ethical, and cultural. (Finch 2012, paras. 38-39)

It took close to 20 years for reconciliation to reach the top of the policy agenda. In 1996 the Royal Commission on Aboriginal Peoples (RCAP) released its exhaustive report on the settler-Indigenous relationship in Canada - coincidentally in the same year that the last of Canada's Indian Residential Schools shut its doors, ending what David Newhouse has called the "Long Assault" on Indigenous culture, language, governance, and identity. (Newhouse 2016, 3) The following year, The Government of Canada's response to the RCAP report entitled Gathering Strength: Canada's Aboriginal Action Plan, opened with a "Statement of

\footnotetext{
2 "Patriation" refers to the period in Canadian legal and political history, culminating in 1982, when Canada adopted a domestic amendment formula for its Constitution, allowing for changes to constitutional law without the passage of an act of British Parliament, as was previously necessary.
} 
Reconciliation" in which it expressed "profound regret" for past Indigenous policies, and committed to the implementation of Aboriginal self-government and the renewal of treaty relationships. (Government of Canada 1997; see also Newhouse 2016, 2; Walters 2010, 174) In 2016, I was fortunate enough to be involved in a national conference in Winnipeg commemorating the $20^{\text {th }}$ anniversary of the RCAP report. Looking back, it was clear that the TRC report was a forceful reiteration of what Canada ought already to have known about reconciliation for two decades.

How should "reconciliation" be understood? There remains considerable uncertainty on this point. In his work, Mark Walters distinguishes between three main approaches to reconciliation. First, "reconciliation as relationship" implies a coming together of two parties after a period of separation. Second, "reconciliation as resignation" signifies the acceptance by one of the parties that the status quo is unlikely to change. Third and finally, "reconciliation as consistency" fits disparate views together by creating a moral equivalence. Depending on the manner in which this equivalence is achieved, this third view of reconciliation can be either symmetrical or asymmetrical. These all share the achievement of harmony, but imply different levels of cooperation and compromise for one or both parties being reconciled. In reference to Supreme Court jurisprudence on Aboriginal rights, Walters argues that the use of common law precedent reflects "reconciliation as consistency", but often by privileging common law traditions and downplaying Indigenous legal orders. (Walters 2010, 167-69; Dorries 2012, 145 47; see also McCrossan and Ladner 2016)

Is this the kind of reconciliation Canadian society is seeking? Both David Newhouse and John Ralston Saul argue no. They recall that prior to Contact, Indigenous societies secured alliances and confederacies through negotiating and renewing mutually beneficial relationships. 
(Newhouse 2016, 6; Saul 2009, 690) This tradition carried through to the original treaty relationships with European colonists. A primary example is the Covenant Chain alliance between the Haudenosaunee and emissaries of the British Crown. Rendered as a wampum belt, the alliance is depicted by two figures linked by a single beaded line, representing a silver chain in need of occasional polishing. Robert A. Williams explains its significance:

From both the English and Iroquois perspective, the Covenant Chain was a relationship of trade and collective security, designed to counter the French-based commercial and military empire centered in Canada. [...] Grounded in Iroquois legal and political traditions prescribing the constitutional organization of multicultural alliances, the Covenant Chain enabled the Iroquois to demand $[\ldots]$ reciprocal treatment and respect as mutual partners in their alliance with the English colonies. [...] As a constitution, the Chain was fundamentally a legal and political text, for both the English and the Iroquois were guided in their relations by its underlying principle of a continually renewed reciprocity of rights and duties. (Williams Jr. 1994, 990-991)

Perhaps, then, the treaty relationship embodies "reconciliation as relationship" between settler and Indigenous nations. (Ariss, Fraser, and Somani 2017, 12-13, 16, 52) But the treaties describe more than a reciprocal relationship: they recognize the political authority and political legitimacy of their respective parties. Settler governments have had no trouble recognizing their own authority, but they have repeatedly rationalized denying the authority of Indigenous governments. (see Stanton 2017, 40) As Newhouse argues: "Reconciliation involves challenging and changing our views of Canada, bringing to the forefront Indigenous histories and understanding the nature of the federation." (Newhouse 2016, 10) Similarly, Michael Asch contends that "[w]hat is needed is an approach that encourages us [settlers] to see that the legitimacy of our settlement on these lands is not opposed to the fact that there were people here living in fully self-determining political societies when we first arrived.”(Asch 2014, 72, emphasis added) 
Brian Slattery argues that recognition and reconciliation are inexorably linked.

"Recognition" requires settlers to acknowledge the independent character of Indigenous modes of governance, as well as the fact that Indigenous and non-Indigenous governments are bound through a body of inter-societal law. "Reconciliation" begins with recognition as a prerequisite, and transforms historic rights into generative rights by negotiation, accounting for contemporary societal and third party interests. (Slattery 2006, 283-85) Put another way, the reconciliation project needs to move from the language of "rights" anchored in historic custom, to "right" in its broadest sense, embodying a comprehensive constitutional relationship. (Walters 2017, 191)

Given these perspectives, what are the key elements of reconciliation, and how will it be defined in this research? One place to start might be the federal government's approach to reconciliation. In a 2018 policy directive, then Minister of Justice and Attorney General Jody Wilson-Raybould defined reconciliation as

an ongoing process through which Indigenous peoples and the Crown work cooperatively to establish and maintain a mutually respectful framework for living together, with a view to fostering strong, healthy, and sustainable Indigenous nations within a strong Canada. Reconciliation requires hard work, changes in perspectives and actions, and compromise and good faith by all. (Department of Justice Canada 2018, 6)

There are many positive elements to this definition: acknowledging reconciliation as an ongoing process built on mutual respect, support for rebuilding Indigenous nations, and a commitment to working in good faith. However, the federal approach is fundamentally forward-looking, and in its effort to break from past wrongs it risks papering over them. In the legal scholarship, reconciliation also requires shared understanding and the acknowledgment of the past. (Tzimas 2011a, 520-21; Stanton 2017, 35) If settler governments wish to restore their relationship with 
Indigenous peoples, there first needs to be a shared understanding of why the relationship broke down. Without this, the appropriate steps for rebuilding the relationship cannot be identified.

For the conception of reconciliation advanced in this research, I look to the Report of the Royal Commission on Aboriginal Peoples. There has been no more comprehensive study of the Crown-Indigenous relationship before or since, and I can think of no better place to start. The Report lays out four basic principles of a renewed relationship: (1) mutual recognition, (2) mutual respect, (3) sharing, and (4) mutual responsibility. As summarized by the Commissioners:

These principles define a process that can provide solutions to many of the difficulties afflicting relations among Aboriginal and non-Aboriginal peoples. [W] have chosen a circle to represent this process because a circle has no beginning and no end; the process is continuous. As we move through the cycle represented by the four principles, a better understanding is gradually achieved. As the cycle is repeated, the meanings associated with each principle change subtly to reflect this deeper level of understanding. In other words, no single, allencompassing definition can be assigned to any of the principles. They take on different meanings, depending on the stage we reached in the whole process. When taken in sequence, the four principles form a complete whole, each playing an equal role in developing a balanced societal relationship. Relations that embody these principles are, in the broadest sense of the word, parterships. (Royal Commission on Aboriginal Peoples 1996a, 1:677-78)

Relationships built on the back of the four RCAP principles are premised on respect and equality, and clear political space for Indigenous nations to assert their governance rights. (see Ariss, Fraser, and Somani 2017, 24, 51; Kapyrka 2018) But as Dorries cautions, "The challenge of achieving the goals described in the RCAP report lie in the translation of these goals into practice." (Dorries 2012, 139)

At the beginning of this chapter I referred to the "settler recognition of Indigenous sovereignty." It is a phrase I will return to often in this dissertation. Stemming from Slattery's reasoning, it refers to the understanding among non-Indigenous Canadians that Indigenous 
nations hold political legitimacy, and by extension should be able to exercise jurisdiction in matters pertaining to their rights and governance. Settler recognition extends from a reevaluation of Canada's past and understands the legacy of the colonial project.

Patrick Wolfe's seminal work on settler colonialism is helpful in understanding the "logic of elimination" that permeates colonial history. Colonial economies were built upon a foundation of agriculture and primary industries such as timber, mining, and pastoralism; all of which required securing access to land. (Wolfe 2006, 395) With Indigenous societies already established on that land, the settler colonial project required the displacement and ultimate dissolution of Indigenous polities to secure access for settlers. All of this was couched in legal doctrines and policies to legitimize acts of dispossession, displacement, and cultural genocide. In the words of Wolfe: "invasion is a structure, not an event" (Wolfe 2006, 388 emphasis added) As will be further explored in the next chapter, the colonial project began innocuously enough. When European settlement in North America was precarious, and dependent on alliances and trade with Indigenous peoples, treaties secured access to land through commitments to coexistence and sharing. These promises were increasingly walked back in the $19^{\text {th }}$ century when colonial societies became self-sustaining, and alliances were replaced by tools of cultural genocide such as the Indian Act, the Pass System, and residential schools.

Generations later, contemporary public servants find themselves managing a colonial legacy from which they continue to benefit, and yet had little to no hand in creating. But as Brian Slattery argues, just as settler law built up colonial systems, settler law can also be adapted to restore treaty relationships:

The dispossession of Indigenous peoples was contrary to the common law and did not extinguish aboriginal title, in the absence of clear and plain legislation to that 
effect. However, the scope and practical effects of dispossession were so significant that as time passed the situation became increasingly difficult to reverse without severely affecting the interests of innocent third parties and the public at large. In the end, the remedy originally envisaged at common law - the expulsion of individuals who occupied unceded Indigenous lands - was no longer practicable on a large scale. Given this new reality, the common law did not remain idle but adapted to take account of the change in circumstances. The adaptation was shaped by three needs: to ensure the continuity of aboriginal title and its recognition in a modern form; to supply appropriate remedies for the wrongs visited on Indigenous peoples; and to accommodate public and private interests in the lands concerned. These needs gave rise to common law Principles of Reconciliation [...] governed by the honour of the Crown.(Slattery 2006, 26162)

In light of these considerations, the settler recognition of Indigenous sovereignty sees Indigenous nations as legitimate political entities with sovereignty claims that remain intact in spite of the settler colonial project.

First Nations, properly speaking, are the original societies and peoples which inhabited the territory now called Canada prior to Contact. These represent a much smaller number of distinct cultural communities than the (current) 635 Band Councils would suggest, with each culture holding a greater governance capacity than any one Band Council could mobilize. ${ }^{3}$ It is at this level which the RCAP report argued was most appropriate for the exercise of selfdetermination and self-government. (Royal Commission on Aboriginal Peoples 1996b, 2:234; McNeil 2007, 7) The concept of Indigenous nationhood pre-dates European contact, and the "nation-to-nation" relationship was first codified in the Peace and Friendship treaties of the late $17^{\text {th }}$ to mid-1 $8^{\text {th }}$ centuries. (Henderson 1994; Borrows 1997b; Williams Jr. 1994; Miller 2013; 2018) Indigenous resistance to the 1969 White Paper on Indian Policy carried this idea into the modern era, and served to remind non-Indigenous governments of their original promises. For

\footnotetext{
${ }^{3}$ As Kiera Ladner argues, Band Councils are not nations. Band Councils are colonial structures designed to administer First Nation communities on behalf of the Government of Canada, operating as quasi-municipalities under the Indian Act. (Ladner 2006, 8-11)
} 
example, in response to the proposed construction of the Mackenzie Valley Pipeline, the Dene people of the Northwest Territories issued a declaration in 1975. In it they asserted:

The Dene find themselves part of a country. That country is Canada. But the Government of Canada is not the government of the Dene. The Government of the N.W.T. is not the government of the Dene. These governments were not the choice of Dene, they were imposed upon the Dene.

What we the Dene are struggling for is the recognition of the Dene Nation by the governments and peoples of the world.

And while there are realities we are forced to submit to, such as the existence of a country called Canada, we insist on the right to self-determination as a distinct people and the recognition of the Dene Nation.

$[\ldots]$

What we seek then is independence and self-determination within the country of Canada. This is what we mean when we call for a just land settlement for the Dene Nation. (“The Dene Declaration” 1976 [1975], 3, emphasis added)

Because Indigenous polities pre-date Contact, settler governments often define the scope of self-government as contemporary expressions of pre-Contact history. However, scholars of Indigenous rights have raised red flags about this view, arguing that it distorts the nature of the original treaty relationship. Rights embodied in treaties are not "frozen" in time, because they embody a nation-to-nation relationship that requires periodic renewal - polishing the Covenant Chain - to reconcile settler and Indigenous sovereignties in the same territory. The logical extension of this is the recognition that Indigenous people require the political space to address contemporary policy challenges affecting their peoples, which has a much wider scope than historic practice. (McNeil 2007; McCrossan 2012; Borrows 1997a; 2017; Starblanket 2019, 444-49) 
The following section shows that the reconciliation of settler and Indigenous sovereignties is not such a departure from the diversity that Canadian federalism already embodies.

\section{B. Canadian Federalism and the Indigenous Order}

Slattery argues that for much of Canadian history, an "imperial model" of the Canadian constitution has dominated legal thinking. This model holds that the original inhabitants of the territory had no legal status of their own, and that the legal order was imported from Britain and France, vesting all legal authority in the Crown, which then delegated its authority to Indigenous peoples as it saw fit. (Slattery 1996, 103-7; see also McNeil 2019) In contrast, Slattery holds up an alternative "organic model" of the constitution. Under this model, Indigenous peoples are active participants in the creation of a customary or "common law" legal order wherein partial autonomy was negotiated in exchange for allegiance to the Crown, and Aboriginal title was retained to traditional territories except where it had been specifically ceded to the Crown through treaty. Therefore, the Crown acts as "the constitutional trustee of coordinate spheres of jurisdiction rather than their exclusive source." (Slattery 1996, 111)

Canadian constitutional law has been the product of some 400 years of negotiation (See RCAP, "Partners In Confederation" 1993) Slattery notes that the basis of Aboriginal rights law developed as a distinct body of British imperial law (not to be confused with the "imperial model" above) by incorporating an existing set of inter-societal customs between colonists and local First Nations. These customary laws "furnished the presumptive legal structure governing the position of indigenous peoples throughout British territories in North America." (Slattery 2000, 201) The fact is, for the first 200 or so years of Contact, Indigenous peoples were the 
primary sources of political power on the continent. Colonists needed to codify these customary relationships to ensure peace and friendship at a time when their future here was far from certain. The promises that were made then are very much still in effect. They were not matters of temporary convenience for colonists, but as will be discussed in later chapters, relate to the honour of the Crown and principles of fundamental justice. (see Slattery 2006)

Independent of treaty relationships, Canada has had to contend with internal pluralism from its very inception. When New France was ceded to Britain in 1760, the English ruling elite found themselves having to secure the allegiance of an entrenched French population with their own distinct religious and legal traditions. The subsequent Royal Proclamation of 1763 and later the Quebec Act of 1774 offered protections to the French in exchange for allegiance, just as the former would do for Indigenous nations. As such, the French Code civil forms the basis of legal pluralism in Canada, existing on an equal footing with the British common law tradition. Similarly, Confederation in 1867 ensured that provincial governments would administer their own spheres of jurisdiction, requiring frequent negotiation, agreement, and occasionally litigation against the federal government to achieve common policy goals. In the decades since the Supreme Court of Canada displaced the Judicial Committee of the Privy Council as Canada's highest appellate body, the Court has repeatedly chosen to endorse cooperative federalism as a principle for resolving issues of overlapping jurisdiction. (Walters 2017, 207) This is to say that shared jurisdiction requires negotiation and agreement between orders of government. As Hogg and Turpel have argued, "intergovernmental cooperation and sharing jurisdiction and resources in the norm rather than the exception in Canadian federalism." (Hogg and Turpel 1995, 202) 
Anishinaabe legal scholar John Borrows has argued that the common law and civil law traditions have maintained their distinction even as they influence one another, and that dialogue between these bodies of settler law and Indigenous legal orders could benefit the latter:

[T] he integrity of a legal system is not solely dependent on its relative isolation, internal logic, or doctrinal purity. Integrity also depends upon the system's recognition, from within and by others. Recognition secures a jurisdictional space for its operation that encourages the respect of the public and facilitates access to resources. When legal systems do not have to continually defend and justify their existence or worth, they are less vulnerable to arguments that challenge their authenticity. When they gain recognition, they are much freer to interact with other systems without fear of assimilation. (Borrows 2010, 116)

Canada is used to resolving policy conflicts within the federation, but has had limited success applying this same logic to Indigenous governments. (McCrossan and Ladner 2016, 225226) Saul likens Canadian federalism to the metaphor of an expanding circle: "those within the circle would happily adopt newcomers into the circle, providing they accepted certain basic rules. Once they were in the circle, everybody would work out exactly what their relationship would be. Now that sounds strangely familiar."(Saul 2009, 682) It is time settler governments moved beyond the English-French dichotomy, and looked to our treaty relationships to widen the circle. (Newhouse 2016; Saul 2012; Hogg and Turpel 1995, 194)

Similarly, the Royal Commission on Aboriginal Peoples held that: "Shared sovereignty, in our view, is a hallmark of the Canadian federation and a central feature of the three-cornered relations that link Aboriginal governments, provincial governments, and the federal government. These governments are sovereign within their respective sphere and hold their powers by virtue of their constitutional status rather than by delegation" (Government of Canada 1996, 240) Some scholars have argued that to the extent that sovereignty is delegated, it was delegated from Indigenous peoples to the Crown, and not the other way around. Saul, for instance, argues that 
the only conceivable answer to the question of how the Crown acquired title to the land is that it got this title from Indigenous people - placing them at the basis of Canadian political legitimacy. (Saul 2012, 5) Likewise, Kent McNeil argues that by rights the Crown ought to bear the burden of demonstrating how it acquired sovereignty where Indigenous sovereignty has been diminished. (McNeil 2007, 29)

Why should there be such a scarcity of proof for the basis of Crown sovereignty? Slattery accuses Canadian courts of adopting a "judicial posture of deference" in accepting the Crown's sovereignty claims without a valid basis in international law. (Slattery 1987, 735) Similarly, Borrows argues that the Crown has not had to abide by the same standard of evidence for its own sovereignty that it has imposed on Indigenous claims. (Borrows 1999, 573) As Borrows writes, Indigenous peoples are effectively being asked to accept a conquest that never took place:

$[\mathrm{R}]$ econciling Aboriginal perspectives with the common law is troubling for Aboriginal peoples. It is asking them to reconcile their perspectives with the pretence that mere Crown assertions of sovereignty have displaced underlying Aboriginal title. As current jurisprudence stands, Aboriginal peoples are being asked to harmonize their perspectives with the notion that they were conquered. Until the Supreme Court develops a (persuasive) explanation for how the assertion of Crown sovereignty "crystallized" Aboriginal title, Aboriginal perspectives cannot be made to agree with such enchantments. (Borrows 1999, 566-67)

In the absence of justifying the legal basis for Crown sovereignty, writes Mark Walters, Canada's body of Aboriginal law remains law about Indigenous peoples rather than a law of Indigenous peoples. (Walters 2006, 498)

Some Supreme Court jurisprudence has taken up this dialogue, with former Chief Justice Beverly McLachlin affirming that Canada's Indigenous peoples "were never conquered" (Haida Nation v. British Columbia (Minister of Forests) 2004, para. 25), and describing Crown sovereignty as "assumed" (Haida Nation v. British Columbia (Minister of Forests) 2004, para. 
20) or “de facto”(Taku River Tlingit First Nation v. British Columbia (Project Assessment Director) 2004, para. 42), and that treaties are the means of reconciling Indigenous and Crown sovereignties. (Haida Nation v. British Columbia (Minister of Forests) 2004; McNeil 2007; Walters 2010) Nevertheless, the Court has stopped short of invalidating Crown sovereignty. As Borrows writes, if the Crown's assertion of sovereignty were found to have no force or effect, this would create a legal vacuum for settler society which the Court would never tolerate. (Borrows 1999, 584; see also Walters 2006, 502) In other words, Crown sovereignty must be de facto in the absence of treaties, and is only made de jure upon signing treaties with Indigenous peoples. (Walters 2006, 516)

At Confederation, Sections 91 and 92 of the 1867 British North America Act divided jurisdiction between the provincial and federal governments, (British North America Act 1867) giving rise to the so-called "doctrine of exhaustiveness" which holds that all conceivable areas of jurisdiction are taken up by these two orders. However, as Hogg and Turpel have argued, the doctrine may provide for the scope of jurisdiction, but says nothing about the exclusiveness of that jurisdiction.(Hogg and Turpel 1995, 192) While having concurrent powers between settler and Indigenous governments may be consistent with the treaty relationship, it creates the potential for inconsistent laws. (Hogg and Turpel 1995) But this is not insurmountable through agreement. There are examples already on the books in Canada. Both the Nisga'a Treaty in British Columbia and the Yukon Umbrella Final Agreement have paramountcy provisions in the event of conflict. (McNeil 2007; Hogg and Turpel 1995)

As will be further discussed in chapter 3, the Patriation of the Canadian constitution in 1982 and the addition of Section 35 - which recognized and affirmed existing Aboriginal and treaty rights - provided a new avenue for the reconciliation of settler and Indigenous 
constitutional orders. As argued by Kiera Ladner: "the constitution not only affords protection to Indigenous constitutional orders, but it incorporates their recognition - through Aboriginal and treaty rights - into, and reconciliation with, the Canadian constitutional order"(Ladner 2006, 15, emphasis added) With Canada's existing legal and jurisdictional pluralism, tradition of treatymaking, and a means with which to incorporate treaties into the constitution, Canada needs no amendment to reconstitute an Indigenous order of government. (Hogg and Turpel 1995) The main stumbling block in the creation of a new, reconciled relationship is the failure of settler governments to recognize inherent Indigenous sovereignty and institutionalize that recognition. According to Michael Asch, the most obvious explanation for this is an unwillingness to share political power:

To repeat a truism, the political world runs on power, and at the end of the day reason serves power, not the reverse. The problem is that the reasons advanced to justify power with respect to Indigenous peoples are largely unconvincing. Yet we still advance them, perhaps because we do not wish to admit to ourselves that there is no justification beyond power itself to explain why the pre-existence of Indigenous societies must be reconciled with the sovereignty of the Crown and not the other way around. (Asch 2014, 68)

This sentiment is echoed by First Nations activists Arthur Manuel and Grand Chief Ronald Derrickson: "Our colonial masters will not give up their privilege without intense pressure from below. They will not do it out of respect." (Manuel and Derrickson 2017, 202) One of the most successful ways in which Indigenous advocates have exerted pressure on settler governments has been through the courts. The next section examines how Canadian common law shares many of the same functions as Indigenous legal orders. The extent to which these two are reconciled depends largely on the way precedent is employed. 


\section{The Instrumental Use of Precedent}

Canada currently has the constitutional tools to reconcile Indigenous orders of government with Canadian federalism, which implies an interpretive role for judges in the reconciliation process. This dissertation regards the common law as tremendously flexible, and capable of incorporating legal concepts which recognize and affirm the continued existence of Indigenous sovereignty and jurisdiction in the face of asserted Crown sovereignty. Understanding this flexibility also requires some understanding of the way in which legal precedent is employed.

The British common law system ensures legal consistency less through the proscriptive codification of law than through the use of legal precedent. This is governed by the principle of stare decisis - trying like cases alike. As F.L. Morton has argued, this amounts to a kind of reasoning by example. But reasoning by example implies an editorial choice on the part of judges. If the facts of a case do not lend themselves to easy comparison, then judges must look to legal principles in other cases to construct a legal equivalency. Morton argues that this adaptability has led to an increasing departure from stare decisis in constitutional law cases. (Morton 2015, 158)

Likewise, Karl Llewellyn distinguishes between two main views of legal precedent. The "strict view" of precedent, he says, is applied to previous cases which judges may find unwelcome, and so judgment is offered for why the previous case is unlike the case being tried. Following from that, the "loose view" of precedent is applied to welcome cases, where useful legal language exists for application to a current case. (Llewellyn 2015, 162-163) There is evidence to suggest that this "loose view" of precedent has been applied to Aboriginal rights 
cases in Canada. In the landmark 1973 Calder decision which ushered in the era of modern treaty negotiations, the Supreme Court drew upon $19^{\text {th }}$-century American jurisprudence to construct its notion of Aboriginal title. (Calder et al. v. Attorney-General of British Columbia 1973; Walters 2010; Newhouse 2016; Slattery 2006) Similarly, the 1984 Guérin decision reached into tort law to describe the Crown's trustee relationship with Indigenous peoples as a “fiduciary duty”. (Guerin v. The Queen 1984, para. 341)

If the common law is based off of custom and precedent, then the failure to acknowledge Indigenous orders of government is not a failure of the principles of common law, but a failure of recognition itself. (see Asch 1984; Borrows 2010) Indigenous law is also customary, the principal difference being that Indigenous legal orders are based on oral traditions as opposed to written documents, making them "implicit law” rather than "explicit law.” (Miller 2013; Napoleon 2007; see also Borrows 1996) Borrows notes that the retelling of Indigenous laws often changes from one telling to the other, "but such changes do not mean that the story's truth is lost; rather, modification recognizes that context is always changing, requiring a constant reinterpretation of many of the account's elements. First Nations stories take this form because there is an attempt to convey contextual meaning relevant to the times and the needs of the listeners.”(Borrows, 1996, 648) Is this really so different an intellectual task from that performed by judges when laying out their decisions?

How, then, can legal precedent produce policy change? For the answer this thesis looks to theories of dialogue and discourse. 


\section{Democratic Dialogue}

Hogg and Bushell describe a call-and-response relationship between courts and legislatures after the Patriation of the constitution in 1982. The Supreme Court may strike down a law as unconstitutional, or suggest necessary modifications to an existing law - but this is not the final word on the matter. The authors argue that in the overwhelming majority of cases, there is a "legislative sequel" within two years of the judgment being rendered. Thus they refer to this back-and-forth as a "democratic dialogue" between courts and legislatures.(Hogg and Bushell 1997; see also Berger 2015; Roach 2001)

Legislatures are learning from this dialogue, too, and pre-empting constitutional challenges to legislation by engaging in what Hogg and Bushell call "Charter-speak" - outlining their constitutional obligations in legislative preambles. (Hogg and Bushell 1997, 101) For instance, 2009 amendments to the preamble to Ontario's Mining Act drew attention to Aboriginal rights implications:

2. The purpose of this Act is to encourage prospecting, staking and exploration for the development of mineral resources, in a manner consistent with the recognition and affirmation of existing Aboriginal and treaty rights in section 35 of the Constitution Act, 1982, including the duty to consult, and to minimize the impact of these activities on public health and safety and the environment. (Government of Ontario 2009; as quoted in Sossin 2010, 112)

But democratic dialogue as described by Hogg \& Bushell is a conversation about applying the Charter of Rights and Freedoms. Because Aboriginal and treaty rights are affirmed in Section 35 of the Constitution Act, 1982, they are located outside the Charter. This has led to uncertainty over whether judicial decisions on such rights are final, precluding a legislative response. (Hogg and Bushell 1997, 92) More fundamentally, this has led to disagreement over whether the Charter applies at all to Aboriginal rights. 
This debate centers on whether the potential of striking down an Indigenous law on Charter grounds threatens the independence of Indigenous sovereignty relative to other Canadian governments drawing their sovereignty from the Crown. Within the Charter is Section 25, which states that Aboriginal and treaty rights are not 'abrogated or derogated' by any other rights therein. For some, Section 25 acts as a moderating influence for accommodating cultural practices while still applying the Charter to Aboriginal rights. (Royal Commission on Aboriginal Peoples 1996b, 2:226-34; Hogg and Turpel 1995, 199) For others, the collective rights embodied in Indigenous governance systems are not captured by the individualistic and universalizing tendencies of the Charter, (McCrossan 2012,103) meaning perhaps that the only provisions applicable to Aboriginal rights are those on gender equality, given that gender quality is specifically mentioned in Section 35(4). (see McNeil 1996) But perhaps this debate is moot. Kent McNeil argues that after the introduction of Section 35, Aboriginal rights cannot be extinguished unilaterally without the consent of Indigenous peoples, (McNeil 2007, 25) which forces legislators into a position of negotiation anyway.

Indigenous peoples have long considered the treaty relationship to be a constitutional one, but that it has not been recognized as such by settler governments until recently. As Martin Papillon has observed: "Indigenous peoples are considered politically and legally distinct, but they are not recognized neither (sic) as full partners within the federation nor as separate political entities entirely outside of federal boundaries." (Papillon 2011, 292, emphasis in original) But failures of recognition aside, Section 35 has incorporated treaties into the constitution, making them part of the fundamental law of Canada. This constitutional status has increased the importance of the judiciary in interpreting their application. Up to this point, studies of Canadian constitutional law have tended to focus on Charter jurisprudence (see Snow and Harding 2015). 
As will be further explored in the following chapter, treaties represent a body of rights which hold constitutional status, and yet exist independently of the Canadian constitutional order. (McCrossan 2012, 101) There exists a need to apply a theory of judicial influence to this body of rights, and explore the dialogic effect of jurisprudence on Indigenous policy.

Is it appropriate for judges to rule on the application of Section 35? Litigation can prove limiting to discussions of inherent rights, because, as the RCAP Commissioners wrote:

The role of the courts in limited in significant ways. They develop the law of Aboriginal and treaty rights on the basis of a particular set of facts before them in a case. They cannot design an entire legislative scheme to implement selfgovernment. Courts must function within the parameters of existing constitutional structures; they cannot innovate or accommodate outside these structures. [...] Participation in the courts requires Aboriginal peoples to plead their cases as petitioners in a forum of adversaries established under Canadian law. There is a certain irony in this, since in many instances the adversary they face is also the fiduciary that is obligated to protect their interests. The situation is, to say the least, anomalous, and it would appear that the courts cannot really substitute for a political forum where Aboriginal representatives can develop their own visions of political autonomy within Canada. (Royal Commission on Aboriginal Peoples 1996a, 1:xxvi-xxvii)

Similarly, Hogg and Turpel have argued a renewed Crown-Indigenous relationship must arise from a political accord, arguing that "the issues [of self-government] are not suitable for resolution by courts because only political discussions can adequately address matters of jurisdiction, financing and intergovernmental cooperation. Legal reasoning in the constitutional context is not broad enough to embrace all of these dimensions." (Hogg \& Turpel 1995, 190) This point is well taken. It is not the duty of the courts to replace negotiation with judicial fiat, and the work of reconciliation must begin with a process of good faith engagement. (see McNeil 2010, 12-13) That being said, the courts can and do reorient federal practice by outlining the government's legal obligations. That is, they can both prompt and reframe such negotiation. Mark Walters takes a similar position when discussing the honour of the Crown: 
The Court cannot tell Aboriginal or non-Aboriginal individuals to adopt a particular moral position for the purposes of furthering the chances of reconciliation, nor can it tell Aboriginal or non-Aboriginal governments to adopt the decision to reconcile. But, the Court can order the Crown - that is, the government of Canada - to adopt the attitude of honour that is essential for the reconciliation of peoples to flourish. (Walters 2010, 186)

\section{E. Discursive Institutionalism}

How have judges framed reconciliation? Even with the instrumental use of precedent outlined above, they are still constrained by certain understandings of the law. Judges create new legal reasoning, but these ideas do not emerge from a vacuum, so they are simultaneously bound by past jurisprudence. (Schmidt 2008, 314) Michael McCrossan explains:

[J]udges are intricately 'caught up with' and 'bound to' the legal world they are seeking to understand and explicate. [...] However, the structures of the field are not simply determined by judges acting alone, but instead are disseminated and reproduced by legal scholars, lawyers, and other academics working within the field (and appearing before the courts) to advocate particular positions and understandings of the law. In other words, the juridical field is the site of an interpretive struggle between actors over the meaning of the 'text' itself.

(McCrossan 2012, 31-32)

Thus enters Vivien Schmidt's theory of "discursive institutionalism", which will be the approach through which this research understands judicial dialogue and discourse affecting reconciliation. Discursive institutionalism has emerged recently from the established body of New Institutionalism literature in political science. (Lowndes and Roberts 2013; Thelen and Steinmo 1992; Thelen 1999; Streeck and Thelen 2005; Peters, Pierre, and King 2005; Hall and Thelen 2007) It also builds on earlier theories of public discourse from social theorists such as Jurgen Habermas and Nancy Fraser. (Habermas 1998; 2005; Fraser 1992)

As described by Schmidt, discursive institutionalism is an umbrella concept encompassing political science scholarship that both accounts for the substantive content of ideas 
and studies the interactive process through which those ideas are communicated: "Those scholars who speak of discourse address explicitly the representation of ideas (how agents say what they are thinking of doing) and the discursive interactions through which actors generate and communicate ideas (to whom they say it) within given institutional contexts (where and when they say it)." (Schmidt 2008; 2010) The combination of both content and process helps explain why certain ideas succeed and others fail. (Schmidt 2008) In Schmidt's terminology, discursive institutionalism combines both "text" and "context". (Schmidt 2011, 48, 60) It is this context which allows the link to New Institutionalism as a whole. It recognizes that actors are not just restricted by institutions, but also that the institutions themselves shape their goals, that institutions embody a "collective memory" (Schmidt 2010, 9; 2011, 52; see also Thelen 1999). Discursive institutionalism is an interactive process that does not eschew the other new institutionalist schools, but uses them to establish background and context for contemporary discourse. (Schmidt 2010)

One important difference between discursive institutionalism and the other new institutionalist schools is the way it describes change. In other schools, changes are presented as exogenous to the actors involved, whether it is through rational incentives (rational choice), policy shocks (historical institutionalism), or societal norms (sociological institutionalism). In discursive institutionalism, actors themselves think and talk about the institutions governing them, producing an endogenous theory of change which reintroduces agency into the equation. (Schmidt 2010, 2, 10, 14)

Put simply, ideas matter, and the language that actors use to communicate those ideas is not value-neutral. In their work on the language of governance, Hajer and Wagenaar posit that: 
The language of 'governance' seems to help practitioners and theorists alike to unlearn embedded intellectual reflexes and break out of tacit patterns of thinking. This stimulates them to rethink governing, politics and administration against the backdrop of these changing societal processes. Thinking about institutional design nowadays requires sociological input.(Hajer \& Wagenaar 2003, 2)

Courts and legislatures are two players in a larger policy dialogue. Though judicial discourse can come from the "top down" via a reference case for example, policy agents (in this case Indigenous peoples) can use the position of judges instrumentally to relay their discourse from the "bottom up" (see Schmidt 2008, 311; 2011, 57). Troy Riddell explains:

Bottom-up theorists [...] posit two related roles that constitutional rights and judicial decisions can play in the policy process: (1) the opportunity structures presented by constitutional rights and judicial decisions can be used instrumentally by disadvantaged groups to further their policy goals, and (2) the law can have constitutive influences that work to motivate groups to undertake political and legal action, shape the goals that groups seek to achieve, and legitimate certain policy ideas over other in the policy process. (Riddell 2004, 598-599, emphasis added)

Though discursive institutionalism presents us with a useful and dynamic explanation for change, it cannot explain all change. Some actions produce unintended consequences, or actions may be pursued without consideration of consequences in the first place. This in turn can produce material changes to which agents must react. (Schmidt 2010)

That said, the judicial discourse at issue in this research is, by nature, carefully considered and based in a treaty relationship dating back nearly 300 years. As such, discursive institutionalism remains a highly applicable construct for examining the judicial role in settler recognition of Indigenous sovereignty. Furthermore, Schmidt argues that discursive institutionalism does not need to explain all change to provide useful insight regarding institutional context:

Part of the reason many political scientists avoid explanations related to discourse is that it is difficult to separate it from other variables, to identify it as the 
independent variable. But instead of ignoring discourse because of the difficulties, because it might not be the cause, it is much better to ask when is discourse $a$ cause, that is, when does discourse serve to reconceptualize interests, to chart new institutional paths, and to reframe cultural norms?

For this, we need to establish what criteria to use in evaluating whether discourse has a causal influence, that is, when it is "transformative" and when it is not. [...] Factors such as timing, political salience, policy viability, and fit in terms of national values, tradition, and culture are equally important. In the realm of discursive interactions, who is speaking to whom [...] also matters. (Schmidt 2011, 62, emphasis in original)

Let us then turn to the First Nation demands through which this research will consider the settler recognition of Indigenous sovereignty and the role of judicial discourse.

\section{F. The Indigenous Order and Ontario: Outlining the Research}

In September 2018, the federal government unveiled a new Recognition of Rights Framework which was to recast the policy approach between the Government of Canada and Indigenous peoples. However, the Framework was rejected soon after by the Assembly of First Nations. Among the reasons given was the fact that the Framework had no provision for the involvement of provincial governments in the new relationship. (Assembly of First Nations 2018a, 4; see also King 2018) Given that provinces have primary jurisdiction over healthcare, education, energy, natural resources, highways, and other portfolios with implications for Indigenous rights, this is a major oversight. Though Indigenous policy remains officially a federal head of power, the provinces have all acknowledged the policy spillovers by establishing their own ministries of Indigenous affairs. Furthermore, provincial and federal ministers sharing this file have established a new forum for the purpose: the Federal, Provincial, Territorial and Indigenous Forum (FPTIF). (Assembly of First Nations 2018b; Newhouse 2016, 10)

But all this remains relatively new, and scholarship on Canadian Indigenous policy has focused overwhelmingly on the federal role. This dissertation contributes to closing that gap in 
scholarship by drawing attention to Indigenous policy in Ontario, specifically the duty to consult and accommodate First Nations. Thus the following question is asked: Is judicial discourse on the duty to consult and accommodate evident in Ontario's First Nation consultation policies? If so, have any systemic changes occurred as a result?

Why the duty to consult? This research aims to better understand the settler recognition of Indigenous sovereignty, and so must look to where that recognition exists. As will be explored in full in Chapter 4 of this dissertation, the duty first appeared in the jurisprudence in the 1997 case of Delgamuukw v. BC, but was accorded full definition in the 2004 Haida Nation v. BC case. Fundamentally, the duty embodies an acknowledgement that First Nations act as a check on the power of settler governments to impose their policy agenda. (see Sossin 2010) The mere fact of requiring consultation implies that First Nations hold rights which require negotiation and accommodation. Consultation signals both the acknowledgement of and respect for those rights. It is also an opportunity to foster sustainable Crown-Indigenous relationships. (Hill Sloan Associates, Inc. 2008, sec. 2.1.1) The duty to consult and accommodate arises from Section 35 of the Constitution Act, 1982, and because of its constitutional status, this duty forms part of the fundamental law of Canada, taking priority over legislation. (Newman 2014, 8) As Ariss et al. have argued: "A failure to directly connect protection of Aboriginal rights with the duty to consult and accommodate disrespects the constitutional standing of Aboriginal rights." (Ariss, Fraser, and Somani 2017, 52) Lastly, the Court's positioning of duties of consultation and accommodation out "in front" of the Crown's recognition of rights means that inherent Indigenous rights are strengthened as a counterpoint to the assertion of Crown sovereignty. (Promislow 2013, 64) 
Why Ontario? Of the province's approximately 375,000 Indigenous people self-identified in the 2016 Canadian Census, roughly 237,000 are First Nations, representing 24.2\% of First Nations people in Canada, and up from 23.6\% of First Nations people self-identified in the 2011 National Household Survey. As such, Ontario has the highest absolute First Nations population of any Canadian province. (Statistics Canada 2016; "Fact Sheet 10: 2016 Census Highlights" 2017; “Aboriginal Peoples Highlight Tables, 2016 Census” 2020) The remaining Inuit and Métis residents of the province are omitted for the purposes of this research. Though the Métis and Inuit are identified under Section 35 as Aboriginal peoples alongside First Nations, their respective histories and institutions are also distinct. For the sake of simplicity, this analysis is limited to First Nations in Ontario. As of writing, the province also covers 46 different treaty areas, (Lysyk 2020, 10) and has examples of all major eras of treaty-making in Canada, ${ }^{4}$ from pre-Confederation treaties (1764-1862) to Numbered Treaties (1871-1921) to an Agreement-InPrinciple for a modern treaty with the Algonquins of Ontario (2016) (Borrows 1997a; Indigenous and Northern Affairs Canada 2016).

How will the research question ${ }^{5}$ be answered? Given that it is a two-pronged question, this dissertation includes an in-depth exploration of key Supreme Court decisions relating to the duty to consult and accommodate, as well as the judicial discourse surrounding these duties. By

\footnotetext{
${ }^{4}$ A number of treaties are found within Ontario's borders, beginning with the Treaty of Niagara (1764), commemorated in wampum belts by the Covenant Chain and the Two-Row Wampum. Other pre-Confederation treaties include the Upper Canada Land Surrenders (1764-1862) and the Robinson Treaties (1850). Like the Robinson Treaties, the Williams treaties (1923) are also framed by the Crown as a land purchase. Numbered Treaties in the province include Treaty 3 (1873) and Treaty 9 (1905, extended 1930). The boundaries of these treaties are mapped by Indigenous and Northern Affairs Canada (https://www.aadnc-aandc.gc.ca/DAM/DAMINTER-HQ/STAGING/texte-text/htoc 1100100032308 eng.pdf) Current boundaries for the Agreement-In-Principle with the Algonquins of Ontario stretch along the Ottawa River valley from the Quebec border to the outskirts of North Bay, encompassing much of Algonquin Provincial Park and extending to parts of the St. Lawrence River. (Indigenous and Northern Affairs Canada 2016)

${ }^{5}$ Is judicial discourse on the duty to consult and accommodate evident in Ontario's First Nation consultation policies? If so, have any systemic changes occurred as a result?
} 
applying the concepts of discursive institutionalism and democratic dialogue, as seen above, to Ontario legislation and consultation policies, this research looks for policy responses to legal changes through the use of legal language by the provincial government.

Secondly, once this link is established, the analysis moves from discourse to implementation. Using a series of semi-structured interviews with Ontario civil servants working in ministries overseeing consultations, this dissertation will evaluate whether the spirit of the law - that is the principle of reconciliation as relationship - is borne out in consultation practices. First Nations interviewees who have experience of provincial consultation will offer a final word on Ontario's commitment. The experience of both Indigenous and non-Indigenous practitioners engaged in policy implementation informs the assessment of systemic change.

The historical period under examination lasts from 2003 to 2020. In 2003, the Anishinabek/Ontario Resource Management Council released a consultation guide, jointly developed by the Union of Ontario Indians and the provincial government. (Anishinabek/Ontario Resource Management Council 2003) This allows a glimpse of consultation policy prior to the Haida Nation and Taku River decisions in 2004. The Ontario Liberal party was also elected in 2003, and the Ipperwash inquiry began that same year, bringing the issue of First Nation lands to the fore. A provincial election in the fall of 2018 saw a change in Ontario's government, and bookended the Liberal tenure in office. That year also marked end of the mandate of the Consultation Policy Project Office within the (then called) Ministry of Indigenous Relations and Reconciliation, tasked with the 10 -year review of provincial consultation policies. (Government of Ontario 2016a) Despite this period being dominated by Liberal party rule, the constitutional relationships being examined between First Nations and the Crown-in-Right of Ontario outlast any particular government's tenure. Some very preliminary impressions of the first years of 
Ontario's Progressive Conservative government will be offered in Chapter 6, but it is too early to draw firm conclusions about the that government's overall management of Crown-Indigenous relationships.

The remainder of the dissertation proceeds as follows. Chapter 2 expands upon theories of judicial influence. I offer my own theoretical construct, capturing the role of the judiciary in reconciling Indigenous and settler constitutional orders. I will review the constitutive elements of this construct: "treaty federalism" in the Canadian literature and "judicial federalism" in the American literature, to arrive at what I am calling "judicial treaty federalism", or JTF. Once defined, I will present a logic model of how the JTF construct might answer my thesis question.

Chapter 3 is a largely historical study, wherein I review previous examples of judicial influence on Canadian federalism, notably the "compact theory" of Confederation put forward by the Judicial Committee of the Privy Council. By establishing that judges have historically influenced federalism, I can advance the possibility that they might do so again today with respect to settler recognition of Indigenous sovereignty. To lay the groundwork for key cases in the following chapters, I will then discuss the Indigenous lobby efforts leading up to the Patriation of the constitution in 1982 and in subsequent constitutional conferences. This will firmly establish the importance of Section 35 as a pathway to reconciling constitutional orders.

Taken together, Chapters 4 and 5 will form a narrative of legal change affecting policy change with respect to the duty to consult and the honour of the Crown. Chapter 4 examines the Haida Nation (2004) and Taku River (2004) decisions, which first described the concept of the duty to consult and accommodate as an extension of the Crown's duty of honourable dealing, even in the absence of proof of Aboriginal title. This chapter also airs some concerns around the 
accommodation of Indigenous interests in the absence of clear legal guidance. Chapter 5 begins by discussing Mikisew Cree (2005), this being the first time the duty to consult and accommodate was applied to treaty rights, and frames the discussion of how settler government projects are checked by treaties. This chapter also examines provincial and territorial roles discussed in the Little Salmon/Carmacks (2010), Grassy Narrows (2014), and Tsilhqot'in (2014) decisions. These cases clarify the responsibilities of provincial and territorial governments to consult and accommodate, independently of the federal Crown. These cases also provide a logical link between facets of inherent Indigenous rights, these being Aboriginal title, treaty rights, and jurisdiction. Little Salmon/Carmacks suggests a lack of finality to modern treaty agreements with settler governments, requiring continued consultation. Grassy Narrows provides additional context for treaty rights in Ontario, clarifying whether the provincial or federal Crown holds sovereignty, and therefore a duty to consult and accommodate on treaty lands. Finally, Tsilhqot'in provides key guidance on Aboriginal title in unceded land, and frames not only consultation, but consent in that context.

Chapter 6 moves from the study of the legal landscape into the policy landscape. It explores Ontario's response to the key cases highlighted in previous chapters. It will examine how judicial discourse on the duty to consult and accommodate is reflected in Ontario's consultation policies as examples of dialogue between courts and legislatures. Interviews with both Ontario civil servants and First Nation leaders in the province will examine how those policies have been implemented across ministries, and whether this has produced marked changes to the Crown-Indigenous relationship in practice. The chapter then moves into the analysis of federal leadership in the reconciliation project. Federal actions set the tone for 
provincial Indigenous policy, through funding mechanisms, through agreements, or even through inaction that prompts a provincial response.

The concluding chapter of my thesis will sum up the arguments presented and assess definitively whether there is a discernable direction to judicial influence on First Nation consultations in Ontario. Judicial Treaty Federalism will be restated as a discursive view of judicial influence, and lessons for the future of Indigenous consultation in Ontario will be offered. Finally, limitations and opportunities for future research will be presented.

\section{References}

“Aboriginal Peoples Highlight Tables, 2016 Census.” 2020. Statistics Canada. https://www12.statcan.gc.ca/censusrecensement/2016/dp-pd/hlt-fst/abo-aut/Table.cfm?Lang=Eng\&S=99\&O=A\&RPP=25.

Absolon, Kathy, and Cam Willett. 2004. "Aboriginal Research: Berry Picking and Hunting in the 21st Century." First Peoples Child and Family Review 1 (1): 5-17.

Anishinabek/Ontario Resource Management Council. 2003. "Reaching Effective Consultation." Union of Ontario Indians. http://caid.ca/AnishinaabekConPol2003.pdf.

Ariss, Rachel, Clara MacCallum Fraser, and Diba Nazneen Somani. 2017. "Crown Policies on the Duty to Consult and Accommodate: Towards Reconciliation?” McGill Journal of Sustainable Development Law 14 (1): 3-55.

Asch, Michael. 1984. Home and Native Land: Aboriginal Rights and the Canadian Constitution. Methuen Publications.

2014. On Being Here to Stay: Treaties and Aboriginal Rights in Canada. University of Toronto Press.

Assembly of First Nations. 2018a. "Canada's Proposed Recognition and Implementation of Indigenous Rights Framework: Issues Summary.” Assembly of First Nations.

_. 2018b. "National Policy Forum on Affirming Rights, Title, and Jurisdiction." NationTalk, September 25, 2018. http://nationtalk.ca/story/afn-bulletin-national-policy-forum-on-affirming-rights-title-and-jurisdiction.

Berger, Benjamin L. 2015. “Judicial Review.” In Introduction to Legal Studies, edited by Stephen Tasson, Jane Dickson, Vincent Kazmierski, Betina Kuzmarov, and Sebastien Malette, 5th ed., 52-56. Canadian Legal Studies. Captus Press.

Borrows, John. 1996. “With or Without You: First Nations Law (in Canada).” McGill Law Journal 41: 629-67. 1997a. "Frozen Rights in Canada: Constitutional Interpretation and the Trickster." American Indian Law Review 22 (1): 37-64. 
1997b. "Wampum at Niagara: The Royal Proclamation, Canadian Legal History, and Self-Government." In Aboriginal and Treaty Rights in Canada, edited by Michael Asch, 170. UBC Press. http://www.chiefs-ofontario.org/sites/default/files/files/Borrows-WampumAtNiagara\%20(2).pdf.

_. 1999. "Sovereignty's Alchemy: An Analysis of Delgamuukw v. British Columbia." Osgoode Hall Law Journal 37 (3): 537-96.

-2010. Canada's Indigenous Constitution. University of Toronto Press.

. 2017. "Challenging Historical Frameworks: Aboriginal Rights, The Trickster, and Originalism." The Canadian Historical Review 98 (1): 114-35.

British North America Act. 1867. http://www.justice.gc.ca/eng/rp-pr/csj-sjc/constitution/lawreg-loireg/p1t13.html.

Calder et al. v. Attorney-General of British Columbia. 1973 [1973] SCR 313. Supreme Court of Canada.

Davis, Lynne, and Chris Hiller. n.d. "Engaging Citizens in Indigenous/Non-Indigenous Relations." In Sharing the Land, Sharing a Future, edited by Katherine A. Graham and David Newhouse. University of Manitoba Press.

Department of Justice Canada. 2018. “The Attorney General of Canada's Directive on Civil Litigation Involving Indigenous Peoples.” https://www.justice.gc.ca/eng/csj-sjc/ijr-dja/dclip-dlcpa/litigation-litiges.pdf.

Dorries, Heather. 2012. "Rejecting the 'False Choice': Foregrounding Indigenous Sovereignty in Planning Theory and Practice." PhD, University of Toronto.

https://tspace.library.utoronto.ca/bitstream/1807/65468/1/Dorries_Heather_J_201206_PhD_thesis.pdf.

"Fact Sheet 10: 2016 Census Highlights." 2017. Ontario Ministry of Finance. https://www.fin.gov.on.ca/en/economy/demographics/census/cenhi16-10.pdf.

Finch, Lance S.G. 2012. “The Duty to Learn: Taking Account of Indigenous Legal Orders in Practice.” In . https://www.cerp.gouv.qc.ca/fileadmin/Fichiers_clients/Documents_deposes_a_la_Commission/P-253.pdf.

Fraser, Nancy. 1992. "Rethinking the Public Sphere: A Contribution to the Critique of Actually Existing Democracy." In Habermas and the Public Sphere, edited by C. Calhoun. Cambridge, Massachusetts: MIT Press.

Government of Canada. 1997. "Gathering Strenth: Canada's Aboriginal Action Plan.” Ministry of Indian Affairs and Northern Development. http://www.ahf.ca/downloads/gathering-strength.pdf.

Government of Ontario. 2009. An Act to Amend the Mining Act. SO 2009, c. 21 - Bill 173.

https://www.ontario.ca/laws/statute/S09021.

2016. "Mandate Letter Progress: Aboriginal Affairs." https://www.ontario.ca/page/mandate-letter-progressaboriginal-affairs.

Guerin v. The Queen. 1984 [1984] 2 SCR 335. Supreme Court of Canada.

Habermas, Jurgen. 1998. Between Facts and Norms. MIT Press.

_ 2005. "Three Normative Models of Democracy." In Political Philosophy: The Essential Texts, edited by Steven M. Cahn, 527-41. Oxford University Press.

Haida Nation v. British Columbia (Minister of Forests). 2004a [2004] 3 SCR 511. Supreme Court of Canada.

Hajer, Maarten, and Henrik Wagenaar. 2003. “Introduction.” In Deliberative Policy Analysis: Understanding Governance in the Network Society, 1-30. Cambridge University Press.

Hall, Peter A., and Kathleen Thelen. 2007. "Institutional Change in Varieties of Capitalism." 
Henderson, James (Sakej) Youngblood. 1994. "Empowering Treaty Federalism.” Saskatchewan Law Review 58: 241-329.

Hill Sloan Associates, Inc. 2008. "First Nation Consultation Framework." National Centre for First Nations Governance. http://www.fngovernance.org/resources_docs/First_Nation_ConsultationFramework.pdf.

Hogg, Peter W., and Allison A. Bushell. 1997. "The Charter Dialogue between Courts and Legislatures (Or Perhaps the Charter of Right Isn't Such a Bad Thing After All).” Osgoode Hall Law Journal 35 (1): 75-124.

Hogg, Peter W., and Mary Ellen Turpel. 1995a. "Implementing Aboriginal Self-Government: Constitutional and Jurisdictional Issues.” The Canadian Bar Review 74 (2): 187-224.

1995b. "Implementing Aboriginal Self-Government: Constitutional and Jurisdictional Issues." The Canadian Bar Review 74 (2): 187-224.

"Honouring the Truth, Reconciling for the Future: Summary of the Final Report of the Truth and Reconciliation Commission of Canada." 2015. Truth and Reconciliation Commission of Canada.

Indigenous and Northern Affairs Canada. 2016. "Algonquins of Ontario Land Claim Negotiations." https://www.aadnc-aandc.gc.ca/eng/1355436558998/1355436749970.

Institute of Public Administration of Canada. 2017. "Public Service Action for Reconciliation: Plan, Educate, Engage.” National Year of Dialogue for Reconciliation \& Renewed Relationships. https://s3.ca-central1.amazonaws.com/ipacreports/NYD+Report+-+Final+-+English.pdf.

Kapyrka, Julie. 2018. “The Space Between: The Benefits of a Pre-Engagement Consultation Model.” Public Sector Digest, October 2018.

King, Hayden. 2018. “Canada’s Indigenous Rights Framework: A (Bad) Proposal Emerges.” Policy Brief, September 19, 2018.

Ladner, Kiera L. 2006. "Indigenous Governance: Questioning the Status and the Possibilities for Reconciliation with Canada's Commitment to Aboriginal and Treaty Rights." National Centre for First Nations Governance.

Llewellyn, Karl. 2015. “This Case System: Precedent.” In Introduction to Legal Studies, edited by Stephen Tasson, Jane Dickson, Vincent Kazmierski, Betina Kuzmarov, and Sebastien Malette, 5th ed., 162-64. Canadian Legal Studies. Captus Press.

Lowndes, Vivien, and Mark Roberts. 2013. “Three Phases of Institutionalism.” In Why Institutions Matter: The New Institutionalism in Political Science, 18-45. Palgrave-Macmillan.

Lysyk, Bonnie. 2020. "Value-for-Money Audit: Indigenous Affairs in Ontario." Office of Auditor General of Ontario. https://www.auditor.on.ca/en/content/annualreports/arreports/en20/20VFM_04indigenous.pdf.

Manuel, Arthur, and Ronald Derrickson. 2017. The Reconciliation Manifesto: Recovering the Land, Rebuilding the Economy. Toronto: James Lorimer and Company Ltd.

McCrossan, Michael. 2012. "Judicial Narratives of Crown Sovereignty, Territorial Space, and the Perpetuation of Legal Magic.” Doctor of Political Science, Ottawa, ON: Carleton University.

McCrossan, Michael, and Kiera L. Ladner. 2016. "Eliminating Indigenous Jurisdictions: Federalism, the Supreme Court of Canada, and Territorial Rationalities of Power." Canadian Journal of Political Science / Revue Canadienne de Science Politique 49 (3): 411-31.

McNeil, Kent. 1996. "Aboriginal Governments and the Canadian Charter of Rights and Freedoms." Osgoode Hall Law Journal 34 (1): 61-99. 
Governance.

- 2010. "Reconciliation and Third-Party Interests: Tsilhqot'in Nation v. British Columbia." Indigenous Law Journal 8 (1): 7-26.

2019. Flawed Precedent: The St. Catherine's Case and Aboriginal Title. UBC Press.

Miller, Jim R. 2013. “Aboriginal-Crown Treaty-Making in Canada: A Many-Splendoured Thing.” In A History of Treaties and Policies, edited by Jerry P. White, Erik Anderson, Jean Pierre Morin, and Dan Beavon, 7:3-12. Aboriginal Policy Research. Thompson Educational Publishing.

—. 2018. "Compact, Contract, Covenant: The Evolution of First Nations Treaty-Making." In Reconsidering Conferderation: Canada's Founding Debates, 1864-1999, edited by Daniel Heidt, 19-51. University of Calgary Press.

Milloy, John S. 1999. A National Crime: The Canadian Government and the Residential School System, 1879 to 1986. University of Manitoba Press.

https://books.google.ca/books/about/A_National_Crime.html?id=TSGmglyxgzkC\&printsec=frontcover\&source=kp _read_button\&redir_esc $=\mathrm{y} \# \mathrm{v}=$ onepage $\& \mathrm{q} \& \mathrm{f}=\mathrm{false}$.

Morton, F.L. 2015. "Precedents, Statutes and Legal Reasoning." In Introduction to Legal Studies, edited by Stephen Tasson, Jane Dickson, Vincent Kazmierski, Betina Kuzmarov, and Sebastien Malette, 5th ed., 157-59. Canadian Legal Studies. Captus Press.

Napoleon, Val. 2007. “Thinking About Indigenous Legal Orders.” National Centre for First Nations Governance.

Newhouse, David. 2016. “Indigenous Peoples, Canada and the Possibility of Reconciliation.” IRPP Insight, no. 11 (November).

Newman, Dwight. 2014. "The Rule and the Role of Law: The Duty to Consult, Aboriginal Communities, and the Canadian Natural Resource Sector." 4. Aboriginal Canada and the Natural Resource Economy Series. Ottawa: Macdonald-Laurier Institute.

Papillon, Martin. 2011. "Adapting Federalism: Indigenous Multilevel Governance in Canada and the United States." Publius: The Journal of Federalism 42 (2): 289-312.

"Partners In Confederation: Aboriginal Peoples, Self-Government, and the Constitution." 1993. Royal Commission on Aboriginal Peoples. http://data2.archives.ca/rcap/pdf/rcap-441.pdf.

Peters, B. Guy, Jon Pierre, and Desmond King. 2005. “The Politics of Path Dependency: Political Conflict in Historical Institutionalism.” The Journal of Politics 67 (4): 1275-1300.

Promislow, Janna. 2013. "Irreconcilable? The Duty to Consult and Administrative Decision Makers." Constitutional Forum 22 (1): 63-78.

Riddell, Troy Q. 2004. "The Impact of Legal Mobilization and Judicial Decisions: The Case of Official MinorityLanguage Education Policy in Canada for Francophones Outside Quebec.” Law \& Society Review 38 (3): 583-609.

Roach, Kent. 2001. The Supreme Court on Trial: Judicial Activism or Democratic Dialogue. Irwin Law.

Royal Commission on Aboriginal Peoples. 1996a. Looking Forward, Looking Back. Vol. 1. 6 vols. Government of Canada.

- 1996b. Restructuring the Relationship. Vol. 2. 6 vols. Report of the Royal Commission on Aboriginal Peoples. Government of Canada.

Saul, John Ralston. 2009. “The Roots of Canadian Law in Canada.” McGill Law Journal 54: 671-94. 
. 2012. "A Different Model of the Nation-State: Canada in the World and the Aboriginal Influence." Saskatchewan Law Review 75: 3-12.

Schmidt, Vivien. 2008. "Discursive Institutionalism: The Explanatory Power of Ideas and Discourse.” Annual Review of Political Science 11: 303-26.

— 2010. "Taking Ideas and Discourse Seriously: Explaining Change through Discursive Institutionalism as the Fourth 'New Institutionalism.”” European Political Science Review 2 (1): 1-25.

_. 2011. "Reconciling Ideas and Institutions through Discursive Institutionalism.” In Ideas and Politics in Social Science Research, edited by Daniel Beland and Robert Henry Cox, 47-64. Oxford University Press.

Slattery, Brian. 1987. “Understanding Aboriginal Rights.” Canadian Bar Review 66 (4): 727-83.

_. 1996. "The Organic Constitution: Aboriginal Peoples and the Evolution of Canada." Osgoode Hall Law Journal 34 (1): 101-12.

—. 2000. "Making Sense of Aboriginal and Treaty Rights." Canadian Bar Review 79 (2): 196-224.

—. 2006. “The Metamorphosis of Aboriginal Title.” Canadian Bar Review 85 (2): 255-86.

Snow, Dave, and Mark S. Harding. 2015. "From Normative Debates to Comparative Methodology: The Three Waves of Post-Charter Supreme Court Scholarship in Canada." American Review of Canadian Studies 45 (4): $451-$ 66.

Sossin, Lorne. 2010. "The Duty to Consult and Accommodate: Procedural Justice as Aboriginal Rights." Canadian Journal of Administrative Law \& Practice 23: 93-113.

Stanton, Kim. 2017. "Reconciling Reconciliation: Differing Conceptions of the Supreme Court of Canada and the Canadian Truth and Reconciliation Commission.” Journal of Law and Social Policy 26 (2): 21-42.

Starblanket, Gina. 2019. "Constitutionalizing (In)Justice: Treaty Interpretation and the Containment of Indigenous Governance.” Constitutional Forum 28 (2): 13-24.

Statistics Canada. 2016. "Aboriginal Peoples in Canada: First Nations People, Metis and Inuit.” http://www12.statcan.gc.ca/nhs-enm/2011/as-sa/99-011-x/99-011-x2011001-eng.cfm\#a3.

Streeck, Wolfgang, and Kathleen Thelen. 2005. "Institutional Change in Advanced Political Economies." In Beyond Continuity: Institutional Change in Advanced Economies, edited by Wolfgang Streeck and Kathleen Thelen, 1-35. Oxford University Press.

Taku River Tlingit First Nation v. British Columbia (Project Assessment Director). 2004 [2004] 3 SCR 550. Supreme Court of Canada.

“The Dene Declaration.” 1976. Canadian Association in Support of the Native Peoples Bulletin 17 (1): 3.

Thelen, Kathleen. 1999. "Historical Institutionalism in Comparative Politics.” Annual Review of Political Science 2: 369-404.

Thelen, Kathleen, and Sven Steinmo. 1992. "Historical Institutionalism in Comparative Politics." In Stucturing Politics: Historical Institutionalism in Comparative Analysis, edited by Sven Steinmo, Kathleen Thelen, and Frank Longstreith, 1-32. Cambridge University Press.

Tzimas, E. Ria. 2011. “To What End the Dialogue?” Supreme Court Law Review 54: 493-527.

Walters, Mark D. 2006. “The Morality of Aboriginal Law.” Queen's Law Journal 31 (2): 470-520. 
. 2010. "The Jurisprudence of Reconciliation: Aboriginal Rights in Canada." In The Politics of

Reconciliation in Multicultural Societies, edited by Will Kymlicka and Bashir Bashir, 165-91. Oxford University Press.

2017. "Rights and Remedies within Common Law and Indigenous Legal Traditions: Can the Covenant Chain Be Judicially Enforced Today?” In The Right Relationship: Reimagining the Implementation of Historical Treaties, edited by John Borrows and Michael Coyle, 187-207. Toronto: University of Toronto Press.

Williams Jr., Robert A. 1994. "Linking Arms Together: Multicultural Constitutionalism in a North American Indigenous Vision of Law and Peace.” California Law Review 82 (4): 981-1049.

Wilson, Shawn. 2008. Research Is Ceremony: Indigenous Research Methods. Fernwood Publishing.

Wolfe, Patrick. 2006. "Settler Colonialism and the Elimination of the Native." Journal of Genocide Research 8 (4): $387-409$. 


\section{Chapter 2: Federalism Literature and the Emergence of Judicial Treaty Federalism}

The study of Crown-Indigenous relationships in Canada and the study of federalism go hand in hand. Both subjects relate to how sovereignty and jurisdiction is shared in this country, and indeed the very source of political authority itself. Although Canada's constitutional arrangements will be further explored in the next chapter, this chapter provides a theoretical lens through which to view the role of treaty law in Canadian federalism, and the role of judges in interpreting it. Although Canadian judges are operating within the settler legal system, they can (and have) imposed legal limits to the exercise of Crown sovereignty such as the duty to consult and accommodate, forcing settler governments to account for the continued existence of Indigenous sovereignty.

The theoretical lens put forward in this research, "judicial treaty federalism", incorporates elements of "treaty federalism" in Canadian scholarship and "judicial federalism" in American scholarship, and applies the interpretive role of the judiciary to treaty law and the unique place that Indigenous nationhood holds in Canadian federalism, irrespective of their treaty arrangements. How this discourse is taken up by Ontario policymakers and translated into provincial policy will permit the closing chapters of this dissertation to gauge the effect that judges have in renewing Crown-Indigenous relationships, and the place that Indigenous nations hold relative to public governments.

\section{A. Treaty Federalism}

Emerging around the Canadian constitutional debates of the early 1990s, thanks largely to the seminal work of James (Sakéj) Youngblood Henderson, "treaty federalism" describes a constitutional compact that was created when North American Indigenous peoples signed treaties 
with representatives of the British Crown, and later the Crown-in-Right of Canada. Treaty federalism recalls that as established societies and prior occupants of the land, Indigenous peoples where the dominant political force in North America for at least two centuries after contact. European precariousness on this continent and colonial power struggles meant that establishing a treaty relationship was by no means inevitable. The Royal Commission on Aboriginal Peoples reviewed this history, describing how French colonists secured economic and military ties with local peoples to facilitate a lucrative fur trade with Europe. When New France was ceded to Britain in 1763 following the Seven Years War, the British Crown was faced with the problem of ensuring peace with France's Indigenous allies, as well as their own allies angered by the continued incursion of American colonists. (Royal Commission on Aboriginal Peoples 1996a, 1:111-27)

The Royal Proclamation of 1763 outlined the British regime in its newly expanded North American colonies, but it also codified an existing set of economic and political relationships between settlers and First Nations, assuming these under the mantle of the Crown. As the Proclamation states:

And whereas it is just and reasonable, and essential to Our Interest and the Security of Our Colonies, that the several Nations or Tribes of Indians, with whom We are connected, and who live under Our Protection, should not be molested or disturbed in the Possession of such Parts of Our Dominions and Territories as, not having been ceded to, or purchased by Us, are reserved to them, or any of them, as their Hunting Grounds [...]

And We do further declare it to be Our Royal Will and Pleasure, for the present as aforesaid, to reserve under Our Sovereignty, Protection, and Dominion, for the Use of the said Indians, all the Lands and Territories not included within the Limits of Our said Three New Governments, or within the Limits of the Territory granted to the Hudson's Bay Company[...]; and We do hereby strictly forbid, on Pain of Our Displeasure, all Our loving Subjects from making any Purchases or Settlements whatever, or taking Possession of any of the Lands above reserved, without Our especial Leave and Licence for that Purpose first obtained. 
And We do further strictly enjoin and require all Persons whatever, who have either wilfully [sic]or inadvertently seated themselves upon any Lands within the Countries above described, or upon any other Lands, which, not having been ceded to, or purchased by Us, are still reserved to the said Indians as aforesaid, forthwith to remove themselves from such Settlements.

And whereas great Frauds and Abuses have been committed in the purchasing Lands of the Indians, to the great Prejudice of Our Interests, and to the great Dissatisfaction of the said Indians; in order therefore to prevent such Irregularities for the future, and to the End that the Indians may be convinced of Our Justice, and determined Resolution to remove all reasonable Cause of Discontent, We do, with the Advice of Our Privy Council, strictly enjoin and require, that no private Person do presume to make any Purchase from the said Indians of any Lands reserved to the said Indians, within those Parts of Our Colonies where We have thought proper to allow Settlement; but that if, at any Time, any of the said Indians should be inclined to dispose of the said Lands, that same shall be purchased only for Us, in Our Name, at some publick [sic] Meeting or Assembly of the said Indians to be held for that Purpose by the Governor or Commander in Chief of Our Colonies[.](Royal Proclamation 1763)

Shiri Pasternak argues that while the British Crown may have asserted its sovereignty over territories previously claimed by the French, in practice the colonists were not able to assert much territorial jurisdiction until the 1830s. Indigenous nations continued to practice their governance traditions undisturbed for decades, since European precariousness over much of the continent meant that they were economically dependent on continued trade and kinship relationships with Indigenous peoples. (Pasternak 2017, 4, 12-13)

The year after the Royal Proclamation was issued, William Johnson, the British Superintendent for Northern Indians, presented the Proclamation as a treaty at a meeting in Niagara of over 2,000 First Nations representatives from more than 24 different nations. Johnson presented the Covenant Chain wampum belt to the assembled chiefs, and made references to the bond it represented between the Crown, Indigenous peoples, and the divine. (Borrows 1997b; Walters 2006; Slattery 2014; Miller 2018) 
Both John Borrows and J.R. Miller argue that the ceremony which surrounded the 1764 Treaty of Niagara elevates the agreement from mere contract to a covenant, based on the sacred bond referenced in the remarks of agents of the Crown, recollection from oral history, and depictions in wampum. (Borrows 1997b; Miller 2018) This practice continued into the negotiation of the Numbered Treaties in the late $19^{\text {th }}$ and early $20^{\text {th }}$ centuries. (Craft 2011; Miller 2013,2018 ) The importance of the historic use of ceremony in treatymaking is stated succinctly by Mark Walters:

Reading [the] treaty record intelligibly today is impossible without some prior appreciation of aboriginal legal traditions, for it was to those legal traditions that the Crown, through its representatives, submitted when treating with aboriginal peoples. [...] By this custom or law - or "constitution" - the Crown entered into a complex web of spiritual-kinship alliances that structured politics in the aboriginal world: the Crown was thus reconfigured from European sovereign, to whom obedience was due, to aboriginal father or mother with whom gifts were exchanged and the reciprocal duties of care, respect, and protection normal for kindred relations were acknowledged. (Walters 2006, 490-91; see also Craft 2014, 12-19)

These treaties, beginning with the Royal Proclamation, embodied a nation-to-nation

relationship based on shared jurisdiction, shared territory, and Crown protection. (Henderson

1994, 246-53; Slattery 2005, 435-43) As stated the in the RCAP report:

[T] he [Royal] Proclamation portrays Aboriginal nations as autonomous political units living under the Crown's protection and on lands that are already part of the Crown's dominions. Aboriginal nations hold inherent authority over their internal affairs and the power to deal with the Crown by way of treaty and agreement. In a word, it portrays the links between Aboriginal peoples and the Crown as broadly 'confederal'. (Royal Commission on Aboriginal Peoples 1996a, 1:117)

Likewise, Slattery argues:

[The] Royal Proclamation contemplates a quasi-federal structure in which a protective shield of imperial rule is extended over a host of autonomous Indian nations, living with their own governments and laws. These nations are not conquered peoples nor are they subject to direct British rule - rather their connections with the Crown take the form of Treaties periodically negotiated and renewed [and which] form the main supporting columns and beams of the [quasifederal] structure. (Slattery 2014, 327) 
In the treaty federalist view, the rights, responsibilities, and privileges embodied in both historic and contemporary treaties are foundational laws of Canada, irrespective of the extent to which settler governments recognized them as such. (Henderson 1994, 247) Because the treaty relationship describes an allegiance with the Crown and not subservience to the Crown, Indigenous peoples never surrendered their governance rights. (Ladner 2005, 943-48)

The legal status of treaties precedes their formal recognition in the Constitution Act, 1982, but as further discussed below, this relationship only came to be recognized by the Supreme Court of Canada after Patriation. ${ }^{6}$ Henderson quotes one such passage from Justice Lamer in the 1990 R. v. Sioui case:

The mother countries did everything in their power to secure the alliance of each Indian nation and to encourage nations allied with the enemy to change sides. When these efforts met with success, they were incorporated in treaties of alliance or neutrality. This clearly indicates that the Indian nations were regarded in their relations with the European nations which occupied North America as independent nations. (R.v.Sioui (1990) par. 1052-3, as quoted in Henderson 1994, 291)

Henderson further explains that, as a constitutional standard for Canada,

[T]reaty federalism is not a racial, ethnic, religious or linguistic standard. Instead, the idea focuses on the legal documents that interlinked to create Canada rather than on the fate of being born into a race or a particular culture. It is a concept and mechanism that is essential for the elimination of the adverse effects of colonialism and systemic racism in the modern constitutional debate between colonial and Aboriginal peoples about the meaning of Canada. It is also a concept that would make a significant contribution to avoiding conflict.(Henderson 1994, 326, emphasis added)

\footnotetext{
${ }^{6}$ Pre-Patriation cases argued whether certain documents ought to be considered treaties ( $R . v$ White and Bob, 1965), or whether Aboriginal title was unextinguished in the absence of a treaty (Calder v. BC, 1973), but not whether the treaty relationship was constitutional in nature. In Calder, for instance, the Supreme Court firmly grounded the continued existence of Aboriginal title in the Royal Proclamation of 1763, rather than inherent Indigenous rights.
} 
Scholars of treaty federalism have also noted that Indigenous law as embodied in treaties is often analogous to British common law. Kiera Ladner, for instance, remarks that much like the British constitution, Indigenous legal orders are largely unwritten, and based on customs, conventions, and a multiplicity of sources. (Ladner 2005, 937) The principal difference being that these multiple sources are rarely written documents, but may include oral histories, wampum, and other forms of traditional knowledge. (Napoleon 2007, 13-14) To borrow terminology from Val Napoleon, this makes Indigenous law "implicit" law, rather than "explicit" law. For Napoleon, "law functions as law" (Napoleon 2007, 8) regardless of its source, meaning that both explicit law (written) and implicit law (oral) lay down a set of rules for application and interpretation, thus fulfilling the basic purpose of legal order. John Borrows holds a similar view:

The traditions and stories of First Nations are both similar to and different from caselaw precedent. They are analogous to legal precedent because they attempt to provide reasons for, and reinforce consensus about, broad principles and justify or criticize certain deviations from generally accepted standards. Common law cases and Aboriginal stories are also similar because both record the fact patterns of past disputes and their related solutions. Furthermore, First Nations stories are interpreted by knowledgeable keepers of wisdom and presented in a manner that fits a particular dilemma. The stories are regarded as authoritative by their listeners, and there are natural, moral, and cultural sanctions for the violation of their instructions. The interpretation of these stories encourages a basic personal and institutional adherence to underlying values and principles. Each of these factors permits First Nations to look upon the stories as a body of knowledge that fulfils the same functions as Common law precedent.(Borrows 1996b, 647-48)

Bearing this legal tradition in mind, and with the view that treaties embody a nation-tonation compact, treaty federalism calls for the recognition of Indigenous nations as a distinct order of government, co-equal with federal and provincial governments within their respective spheres of jurisdiction. (Henderson 1994, 316; Slowey 2007, 158-59) This requires the mutual recognition of other bodies of law in Canada, (Napoleon 2007, 4) but that recognition has 
historically privileged colonial institutions. Indigenous legal orders went unrecognized because they were simply regarded as inferior by successive colonial governments.

The RCAP report relates how mutual recognition, foundational to the treaty relationship, was walked back over the $19^{\text {th }}$ century. As European pathogens decimated Indigenous populations and the immigration of colonists increased, first peoples began to lose their strength of numbers in settled regions. (Royal Commission on Aboriginal Peoples 1996a, 1:102) Colonists privileged their own interpretation of the treaty relationship, which they regarded as static and contractual. Between 1781 and 1850, the Southern Ontario Treaties, or Upper Canada Land Surrenders, negotiated tracts of land for settlement in exchange for a lump sum payment, often paid in kind. J.R. Miller observes that Upper Canada considered these documents as treaties in name only, and treated them as simple contracts. The Robinson Huron and Robinson Superior treaties of 1850 were exceptions, as they were the first to employ reserve lands as part of a treaty agreement, and preserved harvesting rights for First Nations on the ceded territory. (Miller 2013, 5, 2018, 35-39)

With settlement now firmly established on the continent, little money or effort was devoted to maintaining ongoing relationships with Indigenous peoples, except, as Miller observes, where economic necessity required negotiation. To illustrate his point, Miller points to the discovery of oil at Norman Wells in the Northwest Territories as the pretext for negotiating Treaty 11 in 1921, the last of the Numbered Treaties. (Miller 2018, 44) The colonial project turned away from negotiation and toward assimilation as colonists tried to remake Indigenous peoples in their own image. (Royal Commission on Aboriginal Peoples 1996a, 1:176-79)

This failure to recognize Indigenous rights also played out in law, as exemplified by the 1888 Judicial Committee of the Privy Council decision in St. Catherine's Milling and Lumber 
Co. v. The Queen. (for discussion, see McNeil 2019) The court ruled that Indigenous rights were "personal and usufructuary" (i.e. limited to harvesting) and "dependent on the goodwill of the sovereign."(St. Catherine's Milling (1888) par. 54 as quoted in Borrows and Rotman 1997, $17-$ 18) In so doing the JCPC discounted the sovereignty held by Indigenous nations and held their rights inferior to those of settlers - leaving Indigenous peoples themselves to clarify the constitutional principles embodied in treaties. (Henderson 1994, 286)

Henderson has argued that treaties may rightly be considered the "hidden constitution" of Canada (Henderson 1994, 286; see also Slattery 1984), and further commented that the Imperial Parliament never granted Canadian governments the authority to legislate on behalf of Indigenous peoples. (Henderson 1994, 276) Since the passage of the Indian Act in 1876, and despite the lack of legal grounding, both provincial and federal governments have taken the position that the authority of First Nations is delegated from settler governments rather than based on inherent rights of self-government and self-determination. In Henderson's words: "First Nations were seen as merely pawns in a jurisdictional and fiscal battle between the federal government and the provinces.”(Henderson 1994, 279) Henderson also draws an important distinction between "self-government" under the Indian Act and "self-determination". He characterizes the former as a practical necessity for reserve communities, but which is little related to federal democracy. The latter he equates with treaty federalism, and a reaffirmation of treaties as constitutional documents in Canada. (Henderson 1994, 323-28)

During the constitutional conferences of the early 1980s, First Nations lobbied both Canadian and British parliamentarians to reaffirm the treaty order in constitutional law. (Henderson 1994, 280; see also Sanders 1983) These efforts will be detailed in Chapter 3, but it is generally acknowledged that the introduction of Section 35 into the Constitution Act, 1982 
changed the rules of the game. Section 35(1) of the Act states: "The existing aboriginal and treaty rights of the aboriginal peoples of Canada are hereby recognized and affirmed" (Canada 1982a) “Existing” in Leonard Rotman's view,

[M] eans that all rights that had not been extinguished prior to [...] 1982, including rights which had been all but extinguished through governmental regulation, were given constitutional affirmation and protection in their full and complete form prior to their regulation. [...] In imparting protection to Aboriginal and treaty rights, section 35(1) severs any existing regulation of those rights. (Rotman 1997, 41)

Constitutional recognition of treaty rights amounts to an important restraint on sovereign power for the federal government. (Henderson 1994, 283) Kent McNeil goes further, arguing that apart from provisions of gender equality, the inherent right to self-government is not limited by the Charter of Rights and Freedoms. He points out that section 32 of the Charter specifically singles out its application to federal, provincial and territorial governments, but section 25 of the Charter also states that nothing therein shall "abrogate or derogate from any aboriginal, treaty, or other rights or freedoms that pertain to the aboriginal peoples of Canada" (McNeil 1996, 73; see also Canada 1982) This leads him to conclude that apart from Section 35(4) ("Notwithstanding any other provision of this Act, the aboriginal and treaty rights referred to in subsection (1) are guaranteed equally to male and female persons"), any limit to self-determined governance rights would prove unconstitutional. (McNeil 1996, 77)

Borrows and Rotman, for their part, caution us not to construe the uniqueness of Indigenous law as incompatibility with the common law tradition. (Borrows and Rotman 1997, 12) The chapter has already discussed the similarities between the common law and Indigenous legal orders. The unique set of historical circumstances which gave rise to treaties in Canada has been described as sui generis ("of its own kind") by the Supreme Court of Canada, starting with the Guérin v. R. decision of 1984 . This term, say Borrows and Rotman, accurately describes the 
complex relationship between exclusive, overlapping, and sometimes similar bodies of Indigenous and settler law. However, distinguishing Indigenous rights as sui generis presents the challenge of making claims of Aboriginal rights through the common law system, which risks having the content of these rights defined by outsiders. Settler courts and governments could then use these definitions to legitimate continued colonial practice. For instance, the Supreme Court devised a cultural test of rights in the 1996 R. v. Van der Peet decision which based Indigenous rights in pre-contact history. This so-called "frozen rights" approach has been roundly criticized by scholars of Indigenous rights (Borrows 1997a; 2017; Borrows and Rotman 1997; Napoleon 2007b; Slattery 2005) for limiting the ability of Indigenous governments to respond to contemporary policy challenges, and makes governance rights contingent rather than inherent. But, say Borrows and Rotman, there is reason for hope, and the sui generis concept can act as a logical bridge between legal orders:

Using the common law without dismantling its underlying structure does not mean that Aboriginal people are forever trapped and further entwined in the very structure they are trying to escape. [...] For the most part, Aboriginal people will continue to be guided by their own teachings and systems of laws. They have a proud legacy of resistance and survival that has endured through more extreme examples of the law's interference. [...] [U]nder sui generis reformulations the legal territory set 'set apart' and 'reserved' to protect Aboriginal interests is a place where Aboriginal people have a continuing, unextinguished legal interest. In this system, conventional common law analogies have force only to the degree that they can be reconciled with the 'tradition, custom, practice or law' of the Aboriginal group claiming the right. As such, this sui generis territory allows for the expression and protection of Aboriginal rights that existed prior to, and independently of, the common law.(Borrows and Rotman 1997, 30-31)

This speaks to a deeper truth about the nature of treaty federalism: that the legal and constitutional tools for its implementation are already in hand. With Section 35 as a bridge, no constitutional amendment is necessary for the expansion of an Indigenous order of government based on historic and modern treaties. As Kiera Ladner has argued: "[Section 35] raises the 
possibility of decolonization because [...] the constitution not only affords protection to Indigenous constitutional orders but it incorporates their recognition - through Aboriginal and treaty rights - into, and reconciliation with, the Canadian constitutional order" (Ladner, 2006: 15) Henderson asserts that treaties are the basis for reconciliation and renewal of the nation-tonation relationship. (Henderson 1994, 329) Without this, the relationship can never be renewed.

\section{B. Judicial Federalism}

Judicial federalism emerged in the mid- to late 1970s in American legal and constitutional scholarship, largely at the encouragement of Justice William J. Brennan of the US Supreme Court. (Tarr 1999, 1112; see also Brennan 1977) Brennan found himself a minority liberal voice in a largely conservative Court, and urged that State Supreme courts take up the mantle of civil rights jurisprudence. In a seminal 1977 article, Justice Brennan reflected upon the federal shift in civil rights jurisprudence. He recalled how the Great Depression necessitated the creation of a raft of new federal agencies - agencies which persisted long after the Depression ended. This expansion of federal purview kept, in Brennan's words, "lawyers everywhere very federal law minded" (Brennan 1977, 490) State judges in this era tended to consider federal law a matter for federal courts, but as we will see below, Brennan argued the $14^{\text {th }}$ Amendment carved out an equally important role for states in matters of rights jurisprudence.

The American system of government is built on a system of "dual sovereignties" (Adler $2005,397)$ wherein both the federal government and individual states have their own constitutions, offering rights guarantees in their respective spheres. ${ }^{7}$ But as Brennan observed,

\footnotetext{
${ }^{7}$ It is worth noting that as part of their work on the Harvard Project on American Indian Economic Development, Stephen Cornell and Joseph Kalt have applied this concept of "layered sovereignties" (rather than dual sovereignties) to self-governing tribes in the United States. In this model, self-governing tribes are treated as states, and while subject to federal law and taxation, they are also subject to tribal law rather than state law. (Cornell and Kalt 2010)
} 
these rights have been contested in different legal arenas over time. Expanding upon Justice Brennan's recollections, G. Alan Tarr outlines the conventional wisdom in American legal history that points to three distinct eras of jurisprudence. The first era lasted from the American Revolution to roughly the 1930s. During this time, the Bill of Rights only restricted federal power, which left individual states to rule on rights protections. The second era, lasting from the 1930s to the mid-1970s, was marked by the pursuit of civil rights claims in federal courts, and litigants basing their arguments in state court upon federal law, leading states to follow federal precedent. Finally, from the 1970s onward, a third era developed upon the synthesis of the first two. This era, known as the "new judicial federalism" looked to state constitutions as vehicles for protecting individual rights, independently of the federal constitution. (Tarr 1999, 10991100) Tarr defines new judicial federalism as "the increased reliance by state judges on state declarations of rights to secure rights unavailable under the Unites States Constitution."(Tarr $1999,1097)$ This was sometimes regarded as a rediscovery of a neglected body of state constitutional law, rather than a major shift in jurisprudence. However, Tarr disagrees with this notion, arguing that during the pre-Depression era, the contribution of state courts to civil rights protections was minimal, and it was not until the advent of new judicial federalism that state courts began to rule on civil rights issues such as freedom of speech, religious liberty, and the rights of defendants. As such, new judicial federalism was, in Tarr's view, an unprecedented exercise of state judicial power. (Tarr 1999, 1101-6)

Justice Brennan argued that the encroachment upon civil liberties by either federal or state actors is precluded in the $14^{\text {th }}$ Amendment to the US constitution. The Amendment reads:

14(1) All persons born or naturalized in the United States, and subject to the jurisdiction thereof, are citizens of the United States and of the state wherein they reside. No state shall make or enforce any law which shall abridge the privileges or immunities of citizens of the United States; nor shall any state deprive any 
person of life, liberty, or property, without due process of law; nor deny to any person within its jurisdiction the equal protection of the laws. (United States of America 1868)

This protection permits state supreme courts to extend rights guarantees beyond what is contained in the federal constitution. This extends from the state constitutions embodying not only a distinct order of government, but an independent body of law. Furthermore, state supreme court decisions are not reviewable by the US Supreme Court, as they are beyond the latter's jurisdiction. (Brennan 1977, 499-501) Brennan maintains that this is desirable because American federalism tolerates divergence, and indeed is furthered by divergence, where the result is greater protection for individual rights. (Brennan 1977, 491-503) Likewise, Lawrence Friedman argues that new judicial federalism amounts to a dialogue between different organs of the federal government, and engages the US Supreme Court in discourse over possible interpretations of the constitution. (Friedman 2000, 97)

That being said, an important caveat to new judicial federalism is that state level jurisprudence may not always be rights affirming. State justices are free to interpret constitutional provisions in a more restrictive way than their federal counterparts, even if the same rights protections exist on paper. (Friedman 2000, 136; Tarr 1999, 1116) Critics of new judicial federalism also point out that activist judges who rely on state constitutions to expand rights are engaging in results-oriented jurisprudence, and accuse justices of rule by judicial fiat. But Ronald Collins counters this, arguing that critics are generally satisfied by state justices making reference to federal case law in their arguments. This means that questioning the legitimacy of a state decision simply because it is not based in federal precedent is itself resultsoriented. Instead, Collins calls attention to the importance of legal arguments themselves, and not questions of which case law delivers "more or less" rights. (Collins 1989, 8-18) 
While revolutionary in the first years of its emergence, by the 1990s virtually every US state had examples of judicial decisions based on rights guarantees in their respective state constitutions; and in fact state courts increasingly only made reference to federal law where no state law argument could be made. Thus new judicial federalism became a fixture of the American legal landscape, and drew less and less attention for its use. (Tarr 1999, 1098) Nevertheless, this dissertation argues that there are important lessons from this American school of thought for the Canadian legal landscape, lessons which we will examine further below.

\section{Perspectives on Judicial Activism}

Since the adoption of the Charter of Rights and Freedoms, judicial activism has been the subject of much debate and criticism in Canada. Among the most prominent critics are F.L. Morton and Rainer Knopff, who have argued that Patriation gave the judiciary far too much power over the other branches in the parliamentary system. Morton and Knopff describe judges as the vanguard of a cadre they call the "Court Party", composed of jurists and interest groups (among whom Indigenous organizations are numbered) who have harnessed the Charter of Rights and Freedoms to their own political ends. (Morton and Knopff 2000, 57; Knopff and Morton 2015, 545; see also Morton 2003) The "Court Party" thesis of Morton and Knopff posits that the judiciary has too much power over Parliament, resulting in undemocratic policy change. This view downplays the overriding rights that Parliament has through the Section 1 "reasonable limits provision" or the Section 33 "notwithstanding clause" of the Charter. ${ }^{8}$ Indeed, Morton himself suggests that the Section 33 "notwithstanding clause" constitutes an effective check on the judiciary by reinforcing parliamentary supremacy, so much so that he advocates more

\footnotetext{
8 It is worth noting that Section 35 rights fall outside of the Charter provisions of the Constitution Act, 1982 (McNeil 1996; Roach 2001)
} 
frequent invocation of it. (Morton 2003, 26) The "court party" thesis also overestimates the finality of judicial review, leaving little room for legislative response to judicial decisions (see Hogg and Bushell, 1997). More fundamentally, if constitutions are seen as a social contract between Parliament and the citizens that body serves, then there is nothing undemocratic about using the courts to secure constitutionally protected rights. Indeed, by imposing limits to executive power, this is the essence of constitutional democracy and the rule of law.

I do not share Morton and Knopff's fear of judicial activism, but I do agree with their assertion that "judicial interpretation is analogous to a mini-amendment. The reasoning of judges adds new constitutional meaning that can expand or contract the 'rights' - and thus the policy influence - of the groups involved." (Morton and Knopff, 2000, 59)

Judges, of course, do not come to their decisions in a socio-political vacuum. Judges are one set of policy actors among many, including legislatures, interest groups, bureaucrats, media outlets and the general public. (Riddell 2004b, 586) Judges also learn prevailing standards from one another as decisions and legal arguments make their way through successive appeals. (Tarr 1999, 1110) Stephen Brickey and Elizabeth Comack argue that the law has a distinctly social character, meaning that it is not just an imposed set of rules, but emerges from a particular sociopolitical context. Furthermore, political rights arguments are invariably couched in legal language, meaning that law contributes to a broader societal discourse on rights. (Brickey and Comack 2015, 556-57)

The dialogue metaphor between courts and legislatures has been endorsed by the Supreme Court of Canada in the 1999 Vriend v. Alberta decision as a way to describe the way the legislative and judicial branches of government talk to and listen to one another. (Sossin 2010, 96; see also Roach 2001a) On the topic of judicial federalism, its intellectual godfather, 
Justice William Brennan, envisioned a "growing dialogue between the Supreme Court and the state courts on the topic of fundamental rights"(as quoted in Friedman 2000,113) Similarly, Friedman argues that:

[I]n the Supreme Court, a dialogue about the meaning of constitutional text is joined between the state, via its attorney, and the justices of the Supreme Court a dialogue whose structure parallels that of the dialogue between the federal government and the court in the case of judicial review of federal legislation. [...] By virtue of its give and take structure, dialogue, once joined, serves to curb institutional actions and ambitions, for it naturally pushes participants in the dialogue - and perhaps observers as well - to reconsider closely held positions. (Friedman 2000, 121-22)

Effectively, the disagreement over the role of judicial activism comes down to support for parliamentary supremacy (see, for example, Morton 2003, 26-27) or constitutional supremacy on the topic of fundamental rights. Dale Gibson is skeptical of the notion of parliamentary supremacy, arguing that there is always a constitutional document that is immune from alteration by any legislature. (Gibson 1966, 498) To the extent that critics are dissatisfied with judicial interpretation, then perhaps it is a failure of governments and not of judges. Morton, for instance, remarks that judges often hold greater public trust than politicians, (Morton 2003, 28) and Gibson comments that when legislatures fail to pass adequate protections for civil rights, then judges are obligated to protect them. (Gibson 1966, 499) Similarly, Justice Ian Binnie of the Supreme Court of Canada has stated that judges should be considered "umpires, not players" in the interpretation of rights, and the purpose of rights documents such as the Charter (or indeed Indigenous treaties) is to help citizens "fight City Hall". (Binnie 2013, 14-15) Finally, Brickey and Comack suggest that there is a role for courts not only in protecting individual rights, but also collective rights, recognizing that particular groups in society have been subordinated, and that that they have not, in practice, been equally treated under the law. (Brickey and Comack 2015, 562-63) 
The study of judicial assertions of collective rights, in particular those outlined in treaties, requires a new theoretical construct, one which is offered herein through the concept of judicial treaty federalism.

\section{Judicial Treaty Federalism as a Synthesis}

This chapter has spent considerable time discussing new judicial federalism in the United States and current debates on the role of judges. The question remains, then, how do these fit into the Canadian legal and policy landscapes? The following section argues that treaty law is the closest equivalent in the Canadian context.

It is stating the obvious to say Canada and the United States have significantly different constitutional approaches, though we share a history in British common law. Canada does not have distinct provincial constitutions as American states do. Provincial and federal powers are defined alongside one another in the British North America Act of 1867 and the Constitution Act, 1982. Though Canada does have a Bill of Rights, passed in 1960 by the Diefenbaker government, the statute only constrained action within federal jurisdiction. Because the Bill of

Rights contains a primacy clause, it deemed to be "quasi-constitutional", meaning that it is still part of Canadian human rights law, but it, along with provincial human rights legislation, is overridden by the Charter of Rights and Freedoms, since the latter is constitutional law, whereas provincial and federal rights are merely statutory, making them subject to legislative repeal.

Some scholars have argued that prior to Patriation in 1982, Canada had an "implied bill of rights". The term is traced to Chief Justice Sir Lyman Duff of the Supreme Court of Canada, who held in the 1938 Reference Re Alberta Statutes that because Parliament (and as Gibson argues, also any provincial legislature) is premised on free discussion and debate, any provincial 
or federal government that passed legislation limiting freedom of speech would change the character of legislatures themselves, rendering the legislation ultra vires, or beyond the their jurisdiction.(Gibson 1966) Likewise Oliver Mowat, a former Ontario premier and Father of Confederation, argued in the 1880s that the federal power to disallow provincial legislation effectively negated the will of provincial voters. (Morton 2003, 28) A similar argument of federal overreach was made by provincial opponents of the Charter prior to its adoption. (Binnie $2013,8)$

Whether rights were implicit before the Charter or explicit after the Charter, there exists no constitutional separation of provincial and federal rights law in Canada, analogous to state and federal rights law in the United States. New judicial federalism is premised upon judges interpreting a body of rights law that is both constitutional in nature, but exists outside the federal constitution. Aboriginal and treaty rights are a better analog for this body of law than are Canadian provinces. Thus enters "judicial treaty federalism" (JTF), which is premised upon judicial interpretation of Aboriginal and treaty rights. This judicial interpretation, via dialogue between courts and legislatures, acts to shape Aboriginal rights policy, and carries with it the potential to alter the nature of Canadian federalism through the empowerment of an Indigenous order of government. We have seen above how proponents of new judicial federalism argue that the $14^{\text {th }}$ Amendment to the US Constitution shields state civil rights from federal interference. Likewise, Section 35 of the Constitution Act, 1982 accomplishes much the same task for Aboriginal and treaty rights. However, this potential is dependent on the extent to which the inherent governance rights of Indigenous peoples find articulation in common law precedent, and the extent to which this discourse is taken up by policymakers. 
Where does this study fit into the literature on Supreme Court jurisprudence? Legal scholars Dave Snow and Mark Harding describe the "three waves" post-Charter Supreme Court scholarship. These waves have overlapped in the literature, and do not strictly represent a chronology, but rather three distinct approaches to the study of the Supreme Court. "First wave" scholarship focused on the institutional effects of the Charter, and the changing dynamics between branches of government. The "second wave" tended to describe this interaction as a "dialogue" between governments and courts, a term attributed to a seminal article by Peter Hogg and Allison Bushell (Hogg \& Bushell, 1997 ; see also Borrows, 2010). Finally, the "third wave" used Supreme Court rulings to test American theories of judicial activism - but it did so using extensive quantitative analyses, which will not be the case in this dissertation. (Snow and Harding 2015)

Though the theory of judicial treaty federalism bears some similarity to each wave of post-Charter scholarship, its subject matter remains distinct. Where the literature cited by Snow and Harding talks about the effect of the Charter on the role of the judicial branch within federalism, it is worth repeating that Aboriginal and treaty rights protected under Section 35 fall outside the Charter, and thus are neither subject to the Section 1 reasonable limits provision or the Section 33 notwithstanding clause. (McNeil 1996; Roach 2001) As judicial federalism argues of state constitutions, so JTF posits that Aboriginal and treaty rights, while protected under the constitution, remain a distinct body of rights in and of themselves. Bearing this in mind, it becomes apparent that judicial treaty federalism applies Supreme Court scholarship to a distinct arena; one that aims to study the legal discourse surrounding the settler recognition of Indigenous sovereignty. 


\section{E. Caveats to the Recognition of Indigenous Sovereignty Through Common Law}

Borrows and Rotman insist on the importance of introducing Indigenous worldviews into common law jurisprudence, since it relates directly to the rights and freedoms of Indigenous people. (Borrows and Rotman 1997, 26) The Supreme Court itself has held that any ambiguity or conflict over the interpretation of treaties should be resolved in favour of Indigenous understandings (Nowegegick v. R 1983; R. v. Sparrow 1990), and that historical context is important to determine whether a document should be considered a treaty (R. v. White and Bob 1964; R. v. Sioui 1990; R. v. Horseman 1990; see also Borrows 1996, 639-42; Borrows and Rotman 1997, 18; Henderson 1994, 293; Rotman 1997, 26-36)

Miller argues that a historical understanding of treaties may actually help judges unlock Indigenous understandings of the treaties. He distinguishes between these historical and legal understandings:

[L]egal training shapes litigators and judges who are focused on the written word, in contrast to historians' training, which brings them to believe that the written word without its context is literally meaningless. [...] I am not referring to the distinction between written and oral evidence, but text and context. [...] In complex Aboriginal law cases, the limitation imposed by legal orientation to the written word can have severe consequences. (Miller 2013, 8, emphasis added)

Likewise, Aimee Craft posits that, "To understand what was negotiated at the time of treaty, and to construct what it should mean today, requires an independent understanding of the perspectives that the parties brought to the treaty. This view includes an understanding of the normative values and laws of the indigenous people who made the treaty" (Craft 2014, 8)

In other words, a contextual interpretation of treaties requires a deeper understanding of the nature of Indigenous legal traditions. We have seen above that while Indigenous legal orders and the common law share certain temporal similarities which allow cross-cultural comparisons, Indigenous law has certain key distinctions. Common features of Indigenous legal traditions 
include the absence of coercive state institutions, the intertwining of law with moral and spiritual values, and the importance of the "good mind." While the notion of the "good mind" is a valueladen and not easily defined, Mark Walters describes its role in ordering Indigenous polities:

To know the law in any meaningful sense, one must [pursue] the individual quest for that state of mind in which community definitions of duty and responsibility were appreciated and internalized. For people who value both individual liberty and social cohesion, and yet resisted the imposition of coercive state institutions, the idea of the good mind was essential; indeed, we might even say that some of the values that are associated with the rule of law - like a stable and ordered freedom - could not have flourished in such communities without it.(Walters 2006b, 482-83)

Put more simply, Indigenous legal traditions built on the concept of "the good mind" embody a series of relationships, in which duties of care link families, clans, people groups, and the natural world. (Napoleon 2007, 15; Craft 2014, 10; see also Porter 1984; Wilson 2008) Treatymaking ceremonies, as we have seen above, often incorporated traditional kin-making practices, which extended these duties of care to the Crown. (Miller 2013; 2018; Craft 2011) Conceiving the treaty order as a set of relationships stands in opposition to a contractual reading of treaties.

McCrossan, Ladner, Borrows, Rotman, and Walters all argue that the Supreme Court has not sufficiently recognized Indigenous legal orders in a way that prevents justices from adequately questioning basic presumptions of Crown sovereignty and the general application of Canadian federalism (Borrows 1996, 1997a; McCrossan and Ladner 2016; Walters 2010; Borrows and Rotman 1997). Snow and Harding argue that this may be because judges are acting to strengthen the legitimacy of their own institution. (Snow and Harding 2015, 459) Court reasoning does not necessarily align with Indigenous understandings of the treaty relationship, but this may still produce policy effects regardless. As with judicial federalist interpretations of 
state civil rights, judicial treaty federalism is not necessarily rights affirming. Michael McCrossan, for instance, contends that the movement from obliging the Crown to justify Aboriginal rights infringement as argued in Sparrow (1990) to establishing a test for First Nations to prove their rights in Van der Peet (1996) was an important step backwards. (McCrossan 2012; see also Rotman 1997, 42)

More fundamentally, some scholars have questioned the limits of recognition itself to restore the inherent governance rights of Indigenous people. Glen Coulthard argues that to the extent that "recognition" is conceived as something that is granted by a dominant group to a subaltern group, then it will never fundamentally alter the colonial power relationship, because political rights bestowed upon Indigenous peoples by the settler state are treated as delegated rights, rather than acknowledging the inherent governance authority that Indigenous nations possess independently of the Crown. (Coulthard 2007, 442; 2014, 38) Further, settler recognition will be fundamentally limited in scope because, says Coulthard, "colonial powers will only recognize the collective rights and identities of Indigenous peoples insofar as this recognition does not throw into question the background legal, political and economic framework of the colonial relationship." (Coulthard 2007, 451)

The alternative, Coulthard argues, is a state of "reciprocal recognition among equals". (Coulthard 2007, 450) This means that Indigenous peoples themselves are the creators of the terms, values, and conditions by which they are to be represented." (Coulthard 2014, 39) Coulthard questions the extent to which the Supreme Court can recognize Indigenous nations as equal and self-determining, given that the assumption of Crown sovereignty over Indigenous peoples is rooted in racist doctrines such as terra nullius or the Doctrine of Discovery. (Coulthard 2014, 41) He criticizes other Indigenous scholars such as Dale Turner, who argues in 
his book This is Not a Peace Pipe that Indigenous advocates, or "word warriors", need to voice Indigenous worldviews through the language of settler law to achieve reform. That is, to make Indigenous rights cognizable to settler legal systems. (see Turner 2006; see also Walters 2006, 501) But Coulthard cautions against this, warning of the assimilative power of the settler state to co-opt such arguments in order to preserve itself. (Coulthard 2014, 45-47)

To Coulthard's point, Shiri Pasternak gives the example of the Algonquin community of Barriere Lake, located in Quebec. When the community voiced its opposition to mining on their traditional territory, the mining company, Copper One Inc., offered the community an ownership stake in the project. Given their unceded title to the land, the Algonquin were entitled to share ownership of the resources. However, a commercial stake risked transforming their inherent rights over the territory into commercial rights under settler law. (Pasternak 2017, 3)

Coulthard's point is well taken. Indigenous understandings of treaties and the selfimposed limits to Crown sovereignty outlined in the Royal Proclamation reveal a relationship of shared territory and co-equal jurisdiction, except where Indigenous jurisdiction is specifically ceded to the Crown through treaty. The validity of land surrender itself is often under question. For example, noted Indigenous scholar Leroy Little Bear has remarked that "the standard or norm of the aboriginal $[s i c]$ peoples' law is that land is not transferable and therefore inalienable.” (as cited in Starblanket 2019, 453). Rather, as Gina Starblanket argues, the Canadian state requires an interpretation of treaties which includes land surrender so it can displace Indigenous jurisdiction from the territory it wishes to claim. Ironically, this interpretation requires the preexistence of Indigenous legal orders to justify their own displacement by the Crown. (Starblanket 2019,454) This is flatly inconsistent with the shared territory and shared jurisdiction reflected in Indigenous understandings of treaties. 
Given this, it can be convincingly argued that the assumption of Crown sovereignty over Indigenous nations is illegitimate under the law, and represents an abuse of power. (see Pasternak 2017, 16) But power relations must still be confronted, irrespective of their legitimacy. To say that Indigenous nations retain their governance rights under the law is not the same as saying that power relations within the settler state allow them to freely practice their governance rights. That freedom requires recognition by the settler state, and the renewal of treaty relationships.

Law plays a fundamental role in the furtherance of levelling Crown-Indigenous power relations in Canada. Coulthard appears to believe that Indigenous law and settler common law stand in opposition to one another, but authors such as Slattery and Borrows (see Slattery 1996; Borrows 2010) have argued that the treaty relationship created a body of inter-societal law unique to the time and place in which it was created. Canadian federalism has always been built upon legal pluralism, and judges have a key role in renewing those latent institutions that colonial policy had tried so hard to ignore, to engage in what Walters calls a "judicial rhetoric of redemption". (Walters 2006, 497-98) Judges will likely never discredit the Crown sovereignty upon which their authority is based, but they can subject Crown sovereignty to critical interpretation and impose limits to its prerogatives without denying its existence. (Walters 2006, 502-3) This dissertation argues that the duty to consult and accommodate represents an important limit of this kind.

\section{F. Linking Judicial Treaty Federalism with Consultation Policy}

In the introduction to this dissertation, I asked the following question: "Is judicial discourse on the duty to consult and accommodate evident in Ontario's First Nation consultation policies? If so, have any systemic changes occurred as a result?" It remains for me to establish 
how the theory of judicial treaty federalism is linked to provincial consultation policy, such that the question may be answered.

Provincial and federal governments reached a consensus with the courts on consulting one another in the 1981 Reference re Resolution to Amend the Constitution, also known as the Patriation Reference. At issue was whether the federal government had the legal authority to amend the constitution unilaterally without consulting the provinces. The Supreme Court held that while the federal government could indeed legally amend the constitution on its own, a "constitutional convention" of provincial consultation had developed since Confederation which acted to restrain the exercise of federal power. (Binnie 2013, 9-11) This convention is rooted in the "compact theory" of Confederation which we will further explore in the next chapter. But let us accept for now, based on the decision of the Supreme Court, that a constitutional convention exists for consultation between the provincial and federal orders of government. We have also seen in our discussion of treaty federalism that treaties link a third, Indigenous order of government to Confederation. The logical extension should be that a convention also exists in consulting Indigenous governments on matters which affect their jurisdiction.

We have already seen that the constitutional guarantees offered in Section 35 act to limit the exercise of sovereign power by Canadian governments, as is the nature of constitutional rights. The duty to consult and accommodate, first coined in the 2004 Haida Nation case, has a constitutional status stemming from Section 35 rights. (Newman 2014, 8) It is effectively the recognition by settler governments that Indigenous peoples have political legitimacy and sovereignty, requiring them to adjust their policy process. The duty to consult, then, "is a doctrine designed to deal with underlying rights that have uncertainties about them."(Newman 2014, 16, emphasis added) 
There is no need to distinguish between Aboriginal rights and treaty rights under Section 35 as they pertain to Indigenous sovereignty. Treaty federalism does not do so, nor should judicial treaty federalism. To divorce treaty rights from Aboriginal rights is to construe treaties themselves as the source of Aboriginal rights, lending credence to the notion that the powers of Indigenous governments are delegated by the Crown. (see Ladner 2005, 930) Rather, Aboriginal rights were and continue to be held by Indigenous people by virtue of their historic status as selfgoverning peoples. Treaty rights, by contrast, codify the relationship between settler and Indigenous governments. As Chief Justice McLachlin's stated in the Haida Nation case: "Treaties serve to reconcile pre-existing Aboriginal sovereignty with assumed Crown sovereignty, and to define Aboriginal rights guaranteed by s.35 of the Constitution Act, 1982." (Haida Nation v. British Columbia (Minister of Forests), 2004 par. 20; see also McNeil, 2007; Slattery, 2005)

There remains the question of whether judicial decisions on constitutional rights actually operationalize those rights in practice. (see Riddell 2004, 585-96) Having these legal principles in place is one thing, but, says Rotman:

While it is important to articulate these principles, it is equally important to apply them to factual situations if they are to have any meaningful effect. Paying lipservice to these principles while rendering decisions that ignore their theoretical premises, or abandoning them altogether, runs contrary to the premises underlying these doctrines and the intended purpose of including them as part of treaty jurisprudence. (Rotman 1997, 12)

For the treaty federalist idea to actually be put into practice, Aboriginal and treaty rights must be considered in the policy development process, and Indigenous nations involved as governments with jurisdictional interests. (Slowey 2007, 162; Pasternak 2017, 2-16) Gabrielle Slowey remarks that the failure of settler governments to affirm this constitutional status reflects government's paradoxical role as both the promoter of Indigenous self-government and also 
protectors of the status quo. (Slowey 2007, 167) Henderson likewise accuses settler governments of ignoring the legal sovereignty embodied in treaties is favour of "habitual obedience". (Henderson 1994, 313)

If the duty to consult and accommodate is a recognition by settler governments of the existence of Indigenous sovereignty, then a commitment to that duty in policy is a commitment to procedural justice. As argued by Lorne Sossin:

At root, procedural justice is premised upon the unshakeable belief that sensible and reasonable people of good faith are capable of working out their differences if given a fair and transparent process to do so. [...] Consultation, in this sense, may be viewed as analogous to the treaty negotiation process. Courts may ensure the fairness of this process, but will not impose a judicially crafted outcome.(Sossin 2010, 97, 104)

Because the duty to consult requires settler governments to adopt a just process and not impose a particular outcome, (Sossin 2010, 109-13) examining judicial treaty federalism through this practice frees the theory from the results-oriented criticism which has been leveled at scholars of new judicial federalism in the United States. To repeat the point, the potential reform which judicial treaty federalism could bring to the Canadian federation is moderated by the extent to which the inherent governance rights of Indigenous peoples find articulation in common law precedent, and the extent to which this discourse is taken up by policymakers themselves.

In the previous chapter, I argued the importance of discourse and Schmidt's discursive institutionalism as a lens through which to view dynamic policy change. What follows is a visual representation of the avenues of legal and policy discourse which are under investigation in this dissertation, and which may shed light on the extent to which judicial treaty federalism is borne out in government practice. The figure below maps major avenues of discourse between agents 
on the settler side of Indigenous policy debates. Judicial treaty federalism, as described, theorizes the settler recognition of Indigenous sovereignty. For this, Indigenous people themselves must be at the centre of the model, since they are the source of demands for recognition as self-governing peoples. I have used the term "Indigenous advocates" to capture not just Indigenous peoples, but also public intellectuals, activists, and organizations advocating on their behalf.

Both civil servants and politicians occupy the "policy sphere" as described by Schmidt (Schmidt 2008; 2010), in that they are responsible for the drafting, passage, and implementation of (Indigenous) policy. The media, civil society, and politicians (in their public relations capacity) occupy the "political sphere" as described by Schmidt, meaning they are responsible for the legitimation or condemnation of policy ideas. (Schmidt 2008) The judiciary is considered here on its own, as a distinct branch of government and for the independent role it occupies in Canadian society.

I have highlighted in red those avenues of discourse under investigation within the JTF construct. Neither the judiciary nor the civil service are isolated from political discourse, civil society discourse or Indigenous advocacy, but have a dialogic relationship to one another indicated by the "dialogue theory" label at the intersection of legal judgment and public policy. This dialogue can be witnessed where judicial discourse is expressly written into the text of policy or legislation, sending a clear signal on the topic of constitutional rights between legislatures and courts. (see Hogg \& Bushell, 1997; Roach, 2001) 


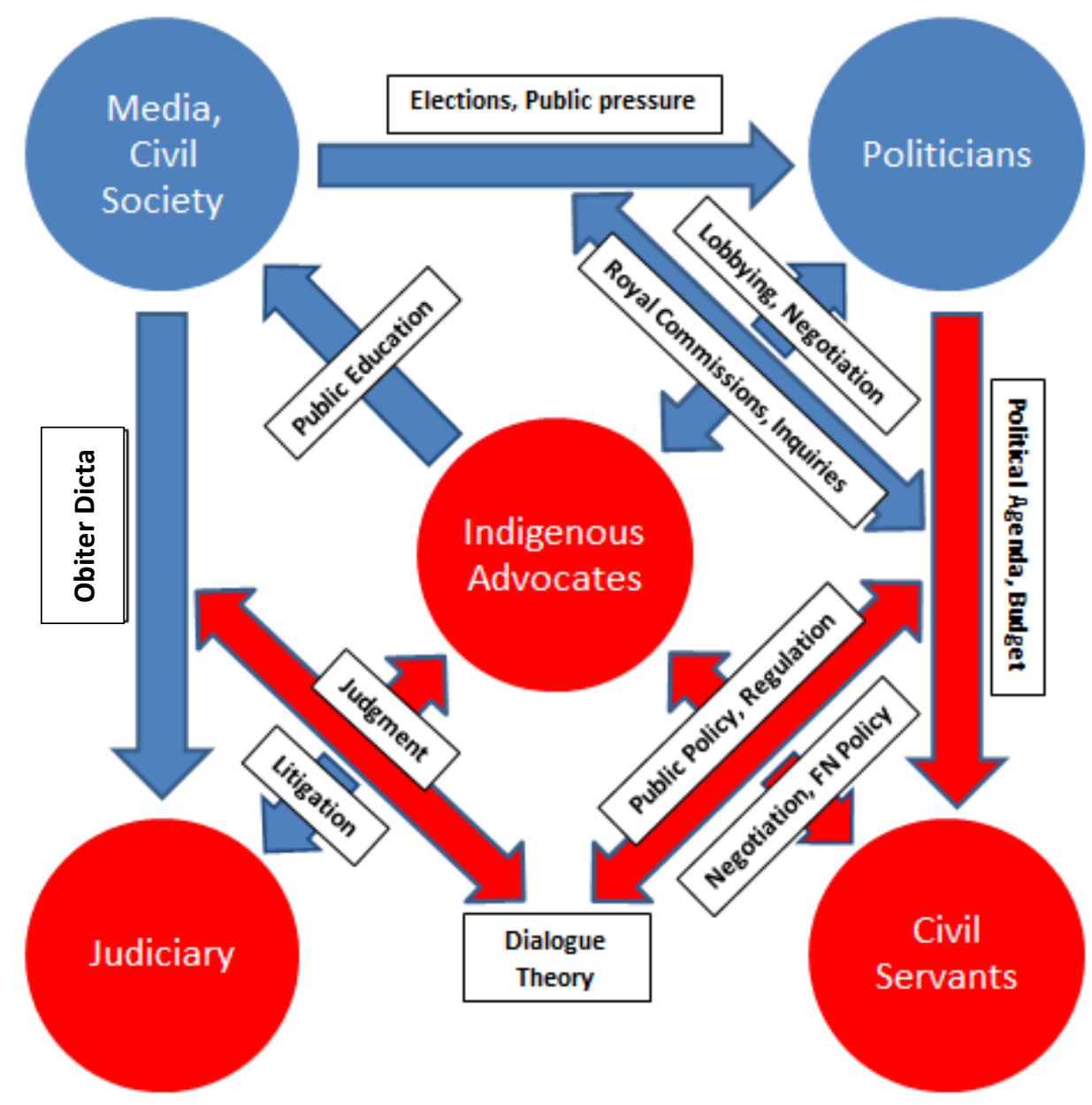

One Ontario example is the revised Mining Act of 2009. The preamble to the legislation states:

2. The purpose of this Act is to encourage prospecting, staking and exploration for the development of mineral resources, in a manner consistent with the recognition and affirmation of existing Aboriginal and treaty rights in section 35 of the Constitution Act, 1982, including the duty to consult, and to minimize the impact of these activities on public health and safety and the environment. (Government of Ontario 2009; see also Sossin 2010, 112)

Though legal requirements are critical to defining the content of the duty to consult and accommodate, Newman remarks that it is often in the interest of government to pursue policies which go beyond the technical legal definitions of the duty. He argues that early engagement in good faith is often the very outcome which Indigenous communities are calling for. (Newman 
2014, 13) In chapter 6 of this dissertation we will examine whether Ontario has risen to this policy challenge. But first, we will examine the historic role of judges in shaping Canadian federalism, and the Indigenous advocacy which enshrined Aboriginal and treaty rights in the constitution.

\section{$\underline{\text { References }}$}

Adler, Jonathan H. 2005. “Judicial Federalism and the Future of Environmental Regulation.” Iowa Law Review 90: $377-474$.

Binnie, Ian. 2013. “Judging the Judges: 'May They Boldly Go Where Ivan Rand Went Before.'” Canadian Journal of Law and Jurisprudence 26 (1): 5-21.

Borrows, John. 1996. "With or Without You: First Nations Law (in Canada).” McGill Law Journal 41: 629-67.

1997a. "Frozen Rights in Canada: Constitutional Interpretation and the Trickster." American Indian Law Review 22 (1): 37-64.

1997b. "Wampum at Niagara: The Royal Proclamation, Canadian Legal History, and Self-Government." In Aboriginal and Treaty Rights in Canada, edited by Michael Asch, 170. UBC Press. http://www.chiefs-ofontario.org/sites/default/files/files/Borrows-WampumAtNiagara\%20(2).pdf.

- 2010. Canada’s Indigenous Constitution. University of Toronto Press.

- 2017. "Challenging Historical Frameworks: Aboriginal Rights, The Trickster, and Originalism.” The Canadian Historical Review 98 (1): 114-35.

Borrows, John, and Leonard I. Rotman. 1997. "The Sui Generis Nature of Aboriginal Rights: Does It Make a Difference?" Alberta Law Review 36 (1): 9-45.

Brennan, William J. 1977. "State Constitutions and the Protection of Individual Rights." Harvard Law Review 90 (3): 489-504.

Brickey, Stephen, and Elizabeth Comack. 2015. "The Role of Law in Social Transformation: Is a Jurisprudence of Insurgency Possible?" In Introduction to Legal Studies, edited by Stephen Tasson, Jane Dickson, Vincent Kazmierski, Betina Kuzmarov, and Sebastien Malette, 5th ed., 556-64. Canadian Legal Studies. Captus Press.

Canada, Government of Canada; Indigenous and Northern Affairs. 1982. Constitution Act, 1982. https://awslois.justice.gc.ca/eng/Const/page-16.html.

Collins, Ronald K.L. 1989. “The Once ‘New Judicial Federalism’ \& Its Critics.” Washington Law Review 64 (5): 5-18.

Cornell, Stephen, and Joseph P. Kalt. 2010. “American Indian Self-Determination: The Political Economy of a Successful Policy.” John F. Kennedy School of Government, Harvard University. https://poseidon01.ssrn.com/delivery.php?ID=41607111010412107912007108301508009104003408603906101109 209212512700911306509007511005311011910611210804906700010911212308400703305103901806011701501 
Coulthard, Glen S. 2007. "Subjects of Empire: Indigenous Peoples and the 'Politics of Recognition' in Canada." Contemporary Political Theory 6 (4): 437-60. http://dx.doi.org.proxy.library.carleton.ca/10.1057/palgrave.cpt.9300307.

2014. Red Skin, White Masks. Minneapolis: University of Minnesota Press.

Craft, Aimee. 2011. "Treaty Interpretation: A Tale of Two Stories."

www.cba.org/cba/cle/PDF/ABOR11_Craft_Paper.pdf.

2014. "Living Treaties, Breathing Research.” Canadian Journal of Women and the Law 26: 1-22.

Friedman, Lawrence. 2000. "The Constitutional Value of Dialogue and the New Judicial Federalism.” Hastings Constitutional Law Quarterly 28: 93-143.

Gibson, Dale. 1966. "Constitutional Amendment and the Implied Bill of Rights.” McGill Law Journal 12 (4): $497-$ 501.

Government of Ontario. 2009. An Act to Amend the Mining Act. SO 2009, c. 21 - Bill 173.

https://www.ontario.ca/laws/statute/S09021.

Haida Nation v. British Columbia (Minister of Forests). 2004 [2004] 3 SCR 511. Supreme Court of Canada.

Henderson, James (Sakej) Youngblood. 1994. "Empowering Treaty Federalism.” Saskatchewan Law Review 58: 241-329.

Hogg, Peter W., and Allison A. Bushell. 1997. "The Charter Dialogue between Courts and Legislatures (Or Perhaps the Charter of Right Isn't Such a Bad Thing After All).” Osgood Hall Law Journal 35 (1): 75-124.

Knopff, Rainer, and F.L. Morton. 2015. "Ardour in the Court.” In Introduction to Legal Studies, edited by Stephen Tasson, Jane Dickson, Vincent Kazmierski, Betina Kuzmarov, and Sebastien Malette, 5th ed., 544-45. Canadian Legal Studies. Captus Press.

Ladner, Kiera L. 2005. "Up the Creek: Fishing for a New Constitutional Order.” Canadian Journal of Political Science 38 (4): 923-53.

_. 2006. "Indigenous Governance: Questioning the Status and the Possibilities for Reconciliation with Canada's Commitment to Aboriginal and Treaty Rights." National Centre for First Nations Governance.

McCrossan, Michael. 2012. "Judicial Narratives of Crown Sovereignty, Territorial Space, and the Perpetuation of Legal Magic." Doctor of Political Science, Ottawa, ON: Carleton University.

McCrossan, Michael, and Kiera L. Ladner. 2016. "Eliminating Indigenous Jurisdictions: Federalism, the Supreme Court of Canada, and Territorial Rationalities of Power." Canadian Journal of Political Science / Revue Canadienne de Science Politique 49 (3): 411-31.

McNeil, Kent. 1996. "Aboriginal Governments and the Canadian Charter of Rights and Freedoms.” Osgoode Hall Law Journal 34 (1): 61-99.

—. 2007. "The Jurisdiction of Inherent Right Aboriginal Governments." National Centre for First Nations Governance.

2019. Flawed Precedent: The St. Catherine's Case and Aboriginal Title. UBC Press.

Miller, Jim R. 2013. "Aboriginal-Crown Treaty-Making in Canada: A Many-Splendoured Thing.” In A History of Treaties and Policies, edited by Jerry P. White, Erik Anderson, Jean Pierre Morin, and Dan Beavon, 7:3-12.

Aboriginal Policy Research. Thompson Educational Publishing. 
_ 2018. "Compact, Contract, Covenant: The Evolution of First Nations Treaty-Making." In Reconsidering Confederation: Canada's Founding Debates, 1864-1999, edited by Daniel Heidt, 19-51. University of Calgary Press.

Morton, F.L. 2003. “Can Judicial Supremacy Be Stopped?” Policy Options, October, 25-29.

Morton, F.L., and Rainer Knopff. 2000. "Judges, the Court Party and the Charter Revolution.” Policy Options, April, 55-60.

Napoleon, Val. 2007. “Thinking About Indigenous Legal Orders.” National Centre for First Nations Governance.

Newman, Dwight. 2014. "The Rule and the Role of Law: The Duty to Consult, Aboriginal Communities, and the Canadian Natural Resource Sector.” 4. Aboriginal Canada and the Natural Resource Economy Series. Ottawa: Macdonald-Laurier Institute.

Pasternak, Shiri. 2017. Grounded Authority: The Algonquins of Barriere Lake against the State. Minneapolis: University of Minnesota Press.

Porter, Tom. 1984. "Traditions of the Constitution of the Six Nations." In Pathways to Self-Determination: Canadian Indians and the Canadian State, edited by Leroy Little Bear, Menno Boldt, and J. Anthony Long, 14-21. Toronto: University of Toronto Press.

Riddell, Troy Q. 2004. "The Impact of Legal Mobilization and Judicial Decisions: The Case of Official MinorityLanguage Education Policy in Canada for Francophones Outside Quebec.” Law \& Society Review 38 (3): 583-609.

Roach, Kent. 2001. The Supreme Court on Trial: Judicial Activism or Democratic Dialogue. Irwin Law.

Rotman, Leonard I. 1997. "Taking Aim at the Canons of Treaty Interpretation in Canadian Aboriginal Rights Jurisprudence.” University of New Brunswick Law Journal 46: 11.

Royal Commission on Aboriginal Peoples. 1996. Looking Forward, Looking Back. Vol. 1. 6 vols. Government of Canada.

Royal Proclamation. 1763. https://www.aadnc-aandc.gc.ca/eng/1370355181092/1370355203645.

Sanders, Douglas. 1983. "The Indian Lobby.” In And No One Cheered: Federalism, Democracy and the Constitution Act, edited by Keith Banting and Richard Simeon, 301-32. Methuen Publications.

Schmidt, Vivien. 2008. "Discursive Institutionalism: The Explanatory Power of Ideas and Discourse.” Annual Review of Political Science 11: 303-26.

. 2010. "Taking Ideas and Discourse Seriously: Explaining Change through Discursive Institutionalism as the Fourth 'New Institutionalism.” European Political Science Review 2 (1): 1-25.

Slattery, Brian. 1984. "The Hidden Constitution: Aboriginal Rights in Canada." American Journal of Comparative Law 32 (2): 361-91.

_ 1996. "The Organic Constitution: Aboriginal Peoples and the Evolution of Canada." Osgoode Hall Law Journal 34 (1): 101-12.

—. 2005. "Aboriginal Rights and the Honour of the Crown." Supreme Court Law Review 29 (2d): 433-45.

. 2014. "The Aboriginal Constitution.” Supreme Court Law Review 67: 319-36.

Slowey, Gabrielle A. 2007. "Federalism and First Nations: In Search of Space.” In Constructing Tomorrow's Federalism: New Perspectives on Canadian Governance, edited by Ian Peach, 157-70. University of Manitoba Press. 
Snow, Dave, and Mark S. Harding. 2015. "From Normative Debates to Comparative Methodology: The Three Waves of Post-Charter Supreme Court Scholarship in Canada." American Review of Canadian Studies 45 (4): $451-$ 66.

Sossin, Lorne. 2010. "The Duty to Consult and Accommodate: Procedural Justice as Aboriginal Rights." Canadian Journal of Administrative Law \& Practice 23: 93-113.

Starblanket, Gina. 2019. "Constitutionalizing (In)Justice: Treaty Interpretation and the Containment of Indigenous Governance.” Constitutional Forum 28 (2): 13-24.

Tarr, G. Alan. 1999. “The New Judicial Federalism in Perspective.” Notre Dame Law Review 72 (4): 1097-1118.

Turner, Dale. 2006. This Is Not a Peace Pipe: Towards a Critical Indigenous Philosophy. University of Toronto Press.

United States of America. 1868. The Constitution of the United States of America. https://www.law.cornell.edu/constitution.

Walters, Mark D. 2006. “The Morality of Aboriginal Law.” Queen’s Law Journal 31 (2): 470-520. . 2010. "The Jurisprudence of Reconciliation: Aboriginal Rights in Canada." In The Politics of Reconciliation in Multicultural Societies, edited by Will Kymlicka and Bashir Bashir, 165-91. Oxford University Press.

Wilson, Shawn. 2008. Research Is Ceremony: Indigenous Research Methods. Fernwood Publishing. 


\section{Chapter 3: The History and Legacy of Compact Theory}

The preceding chapters have alluded to the role of the courts in the settler recognition of Indigenous sovereignty. This legal reconciliation of parallel sovereignties amounts to a reexamination of Canadian federalism. Interestingly, this is not the first time courts have done this in Canadian history. Precedent can be found in the so-called "compact theory of Confederation" advanced by the Judicial Committee of the Privy Council (JCPC), which until 1949 superseded the Supreme Court of Canada as the country's highest court of appeal. In the pages that follow, this chapter examines what "compact theory" is, how it changed federalism, and its life cycle throughout Canadian history. By examining the analog of provincial rights, it will be argued that Indigenous rights also represent a similar, though distinct, compact. The constitutional talks of the late 1970 s to early 1990 s, and the intense Indigenous activism which accompanied them served to remind non-Indigenous governments of this compact, but the failure of more specific constitutional provisions on Aboriginal and treaty rights have once again left an important place for the judiciary in interpreting the content of key sections.

\section{A. What is Compact Theory?}

Scholars of federalism have offered separate, though related, definitions of compact theory. For some, such as Sébastien Grammond, it helps describe the consensual process of federation: "Compact theory is simply the idea that political authority in a given country derives from an agreement, or compact, between the country's constitutive parts. It assumes that the country results from the coalescence of pre-existing political units or groups through a consensual process.” (Grammond 2016a, 801) For others, such as J.R. Mallory, this compact also carries the duty of the central government to preserve these political units: "the argument is that 
the federal state is composed of several distinct entities which are presumed to have distinct and ascertainable interests which the federal state is bound to maintain. (Mallory 1941, 348, emphasis added).

Paul Romney's analysis of compact theory in Canada further distinguishes between a “provincial compact" and a "national compact."(Romney 1999, 21-24) The former describes the preservation of provincial autonomy within Confederation, resistance to provincial subordination by the federal government, and mandatory provincial consultation (including a veto) in the event of constitutional amendment. Likewise, the "national compact" also calls for political independence and constitutional consultation, but is premised on a cultural compact between English and French. Put simply, the provincial compact describes Confederation as the free association between autonomous political entities (that is, the provinces), whereas the national compact describes the free association of distinct cultures (i.e. "national" in the cultural sense). Romney posits that Québécois proponents of compact theory, such as Thomas-Jean-Jacques Loranger, largely went along with the provincial compact because it substantively preserved the national compact they believed was at the basis of Confederation. (Romney 1999, 28) In essence, the distinction arises from differing conceptions of where local autonomy comes from. Romney explains:

Unlike the Lower Canadian (i.e. national) compact theory, which rested on recognized precepts of the law of nations regarding relations between a conquered people and its conqueror, this Upper Canadian (provincial compact) theory originated in venerable common law ideas which envisaged self-government as an inalienable right of British subjects. (Romney 1999, 29)

The national compact theory can be traced back to the Quebec Act of 1774, which following the collapse of New France offered guarantees to preserve the laws, language, and religion of French Canadians, thereby protecting them from assimilation into the larger Canadian 
polity. Based on these guarantees, the Quebec Act has been called the "Magna Carta" of French Canada. (Stanley 1956, 3; Grammond 2016a, 803)

The colonial Province of Quebec was split into the provinces of Upper and Lower Canada by the Constitutional Act of 1791, with their own respective legislatures and executives. This reinforcement of French Canadian separateness highlighted the cultural distinctions at the heart of national compact theory, but it was also the beginning of provincial autonomy in English Canada which would later give rise to provincial compact theory. (Stanley 1956; Romney 1999; Grammond 2016a) The Union Bill of 1822 which attempted to reunify the Canadas was vehemently resisted by Lower Canadian reformers such as William and Robert Baldwin. In 1828, the Baldwins moved a resolution declaring:

We hold it as a principle never to be abandoned that out Constitutional Act [of 1791] as passed by the Parliament of Great Britain and as accepted and acted upon by us is in fact a treaty between the Mother Country and us, her children of this Colony, pointing out and regulating the mode in which we shall exercise those rights which, independent of that act, belong to us as British subjects, and which, therefore, neither the Parliament of the Mother Country, nor any power upon earth could legally or constitutionally withhold from us; and that thus that act, being in fact a treaty, can only be abrogated or altered by the consent of both parties to it, that is to say, the Mother Country and the Colony. (as quoted in Romney 1999, 28 emphasis added)

In the wake of the 1837 and 1838 Upper and Lower Canada rebellions, the Act of Union of 1840 politically rejoined the two Canadas under a single legislature. The United Province of Canada borne from the Act was marked by in-fighting along linguistic and religious lines, (Cody $1977,57)$ but proved to be a crucible for English-Canadian notions of a provincial compact. The advent of responsible government in the colony caused English Canadians to base their assertions of self-government not in natural law, but in the British Imperial model. (see Beck 1971, 149; Romney 1999, 31) Sébastien Grammond explains: "the advent of responsible government in the British colonies solidified the perception that each colony formed a political 
unit independent, in some respects, from the Imperial authorities. [...] The relationship between the colony and the Imperial government was also described by the idea of compact, in particular, in Upper Canada." (Grammond 2016a, 803) Similarly, Romney argues that Upper Canadian politicians viewed "the constitution of the British empire as a federal system of coordinate sovereignties, with a division of legislative power between British Parliament and the various colonial legislatures remarkably similar to that which Ontario Reformers were to perceive in the BNA Act." (Romney 1999, 29)

The more centralist framers of the 1867 British North America Act (BNA Act), John A. Macdonald chief among them, sought a stronger central government than that of the United States, having just witnessed their civil war over "states' rights" to preserve the institution of slavery. (Cody 1977, 59) In an oft-quoted passage from parliamentary debates on Confederation in 1865, Macdonald argues:

Ever since the [American] union was formed the difficulty of what is called "State Rights" has existed, and this much to do in bringing on the present unhappy war in the United States. They commenced, in fact, from the wrong end. They declared by their Constitution that each state was a sovereignty in itself, and that all the powers incident to a sovereignty belonged to each state, except those powers which, by the Constitution, were conferred upon the General Government and Congress. Here we have adopted a different system. We have strengthened the General Government. We have given the General legislature all the great subjects of legislation. We have conferred on them, not only specifically and in detail, all the powers which are incident to sovereignty, but we have expressly declared that all subjects of general interest not distinctly and exclusively conferred upon the local governments and local legislatures, shall be conferred upon the General Government and Legislature. We have thus avoided that great source of weakness which has been the cause of disruption of the United States. (excerpted in Beck 1971, 12-13)

Despite his centralist leanings, which he openly confessed earlier in that same speech, Macdonald also recognized that Confederation would be impossible without preserving the distinction of French-Canadian society, the British common law of English Canada, and the 
"individuality" of the Maritime provinces. (Beck 1971, 12) The resolutions of the Quebec and Charlottetown constitutional conferences in 1864, and later the BNA Act itself, was referred to by many framers as a "treaty" or "pact". Romney summarizes: "Confederation, then, entailed the functional assimilation of the Upper Canadian provincial compact theory and the FrenchCanadian national [compact] theory. The BNA Act did this by restoring the political integrity of Upper and Lower Canada within a new order of colonial responsible government as sovereign polities within a wider federation." (Romney 1999, 31, emphasis added)

But the precise nature of the confederal "treaty" or compact would be contested by successive provincial and federal governments, and it would be left to the Judicial Committee of the Privy Council (JCPC) to give shape to the distribution of powers in outlined Sections 91 and 92 of the BNA Act. (see Appendix A) Their interpretation would prove a decentralizing force in Canadian federalism, and would fall in and out of favour in Canadian political scholarship over the following decades.

\section{B. The JCPC and the British North America Act}

The JCPC, though based in London, derived its authority as Canada's highest court of appeal based upon the Imperial model which Confederation itself emulated. This model provided for local self-government, but held that all legislatures were subordinate to the Imperial Parliament. (MacDonald 1951, 1024; Slattery 1992, 269) The justices of the JCPC, as members of the British House of Lords, were empowered to declare colonial legislation invalid. The validity of legislation was to prove a recurring theme in the jurisdictional battles between Ottawa and the provinces. 
The first such battle was Citizen's Insurance Company v. Parsons in 1881. The suit began with the purpose of a shop owner, Parsons, collecting on a fire insurance policy, but on appeal it ushered in a larger question of whether Ontario's Fire Insurance Policy Act came under provincial jurisdiction over property and civil rights (Sec. 92(13)), or federal jurisdiction over trade and commerce (Sec. 91(2)). (See Appendix A) Writing for the majority, Sir Montague Smith ruled that "property and civil rights" was to be read expansively to allow provincial jurisdiction over insurance, as there was no indication in the BNA Act that the power should be read narrowly. ${ }^{9} \mathrm{He}$ also alluded to the national compact, pointing to Section 94 of the Act, which empowered the federal government to ensure the uniformity of laws between Ontario, New Brunswick and Nova Scotia, but not Quebec: “The province of Quebec is omitted from this section for the obvious reason that the law which governs property and civil rights in Quebec is in the main the French law as it existed at the time of the cession of Canada, and not the English law which prevails in the other provinces.”(excerpted in Beck 1971, 124)

The following year, Russell v. The Queen ${ }^{10}$ tested whether Canada's Temperance Act of 1878, which allowed Canadian municipalities to introduce local bans on the sale of liquor, fell under Ottawa's general residuary powers or provincial jurisdiction over liquor licensing (Sec. 92(9)), property and civil rights (Sec. 92(13)), and general local matters (Sec. 92(16)). The Committee found that prohibition, in this case, fell under the federal general power, arguing:

Parliament deals with the subject [of prohibition] as one of general concern to the Dominion, upon which uniformity of legislation is desirable, and the Parliament alone can so deal with it. There is no ground or pretence for saying that the evil or vice struck at by the Act in question is local or exists only in one province, and

\footnotetext{
${ }^{9}$ Citizen's Insurance Company v. Parsons (1881), 7 A.C. 96 at 110-111, excerpted in Beck 1971, 124-25 and Dawson 1933, 436-38

${ }^{10}$ Russell v. The Queen (1882), 7 A.C. 829 at 836-842, excerpted in Beck 1971, 111-113
} 
that Parliament, under colour of general legislation, is dealing with a provincial matter only.

The Parsons and Russell cases thus called for expansive readings of Sections 91 and 92 based on the particular legislation before the court. But beginning with Hodge v. the Queen ${ }^{11}$ in 1883, the JCPC increasingly began to view these sections as silos or "compartments" of exclusive jurisdiction. Archibald Hodge was a saloon owner who, in contravention of Ontario's Liquor Licence Act of 1877, served alcohol to patrons playing billiards. His suit contended that the Act was not within provincial jurisdiction. Citing the precedents of Russell and Parsons, Sir Barnes Peacock of the JCPC stated: "The principle which [Russell and Parsons] illustrate is, that subjects which in one aspect and for one purpose fall within section 92, may in another aspect and for another purpose fall within section 91." (excerpted in Dawson 1933, 439) With this in mind, Justice Peacock found that the province had not overstepped its jurisdiction, and furthermore:

[T] he power conferred by the Imperial Parliament had conferred on the local legislature should be exercised in full by that body, and by that body alone. [...] [Provincial legislatures] are in no sense delegates of or acting under any mandate from the Imperial Parliament. When the British North America Act enacted that there should be a legislature for Ontario, and that its legislative assembly should have exclusive authority to make laws for the province and for provincial purposes in relation to the matters enumerated in section 92 as the Imperial Parliament in the plenitude of its power possessed and could bestow. Within these limits of subjects and area the local legislature is supreme, and has the same authority as the Imperial Parliament, or the Parliament of the Dominion, would have had under like circumstances.(excerpted in Dawson 1933, 440-41, emphasis added)

This compartmentalized interpretation quickly became a consistent theme in JCPC jurisprudence over the next half-century. (see Cody 1977, 62) In Liquidators of the Maritime

\footnotetext{
${ }^{11}$ Archibald G. Hodge v. The Queen (1883), 9 A.C. 117, excerpted in Dawson 1933, 438-441
} 
Bank of Canada v. The Receiver-General of New Brunswick (1892), ${ }^{12}$ Lord Watson wrote: "in so far as regards those powers which, by sect. 92, are specially reserved for provincial legislation, the legislation of each province continues to be free from the control of the Dominion, and as supreme as it was before the passing of the [BNA] Act." (excerpted in Greenwood 1974, 251) In the so-called Local Prohibition Case (1896), ${ }^{13}$ Lord Watson further characterized Sections 91 and 92 not as examples of broader powers, as had been held previously, (see Greenwood 1974, 253) but rather as an enumeration of specific powers:

[T] he exclusive authority of the Canadian Parliament extends all matters coming within the classes of subjects which are enumerated in [Section 91]. [...] But to those matters which are not specified among the enumerated subjects of legislation [...] the Dominion Parliament has no authority to encroach upon any class of subject which is exclusively assigned to provincial legislatures. (excerpted in Beck 1971, 122)

Lord Watson's literalism was taken up by his intellectual successor, Viscount Haldane. In Toronto Electric Commissioners v. Snider (1925), ${ }^{14}$ Haldane maintained that "The Dominion Parliament has, under the initial words of section 91, a general power to make laws for Canada. But these laws are not to relate to the classes of subjects assigned to the provinces by section 92." (Dawson 1933, 443) Haldane previously held a similar view of provincial powers in the 1922 reference case re Board of Commerce Act and Combines and Fair Prices Act. In that reference, Haldane further characterized the "peace, order, and good government" clause in the preamble of Section 91 as limited to emergencies and other abnormal circumstances:

In special circumstances, such as those of a great war, such an interest [of the Dominion Parliament] might conceivably become of such paramount importance as to amount to what lies outside the heads in s. 92 , and is not covered by them.

\footnotetext{
${ }^{12}$ Liquidators of the Maritime Bank of Canada v. The Receiver-General of New Brunswick (1892), A.C. 437 at 438 , excerpted in Greenwood, 1974, 251

${ }^{13}$ Attorney-General for Ontario v. Attorney-General for the Dominion and the Distillers and Brewers' Association of Ontario (1896) A.C. 348 at 359-362, excerpted in Beck, 1971, 122-123

${ }^{14}$ Toronto Electric Commissioners v. Snider et al. (1925) A.C. 396, excerpted in Dawson 1933, 442-446
} 
[...] This is a principle which, although recognized in earlier decisions, such as that of Russell v. The Queen, both here and in the Courts of Canada, has always been applied with reluctance, and its recognition as relevant can be justified only by scrutiny sufficient to render it clear that the circumstances are abnormal. ${ }^{15}$

Applying Lord Haldane's logic, if the power to make laws for the peace, order and good government of the Dominion was a federal emergency power, then its application in the Russell case would imply that drunkenness in the late $19^{\text {th }}$ century had been a national emergency!

With the stock market crash of 1929 and the ensuing Great Depression came a push by federal politicians to expand state intervention in the economy, something which would pit centralists against the JCPC's siloed interpretation of the compact theory. The closest the Committee came to allowing jurisdictional overlap was in the 1937 Natural Products Marketing case. In that verdict, the Committee stated "Unless and until a change is made in the respective legislative functions of the Dominion and Province it may well be that satisfactory results for both can only be obtained by co-operation."(as quoted in MacDonald 1951, 1029)

Perhaps the literalism of the JCPC, and particularly of Lord Watson and Viscount Haldane, was simply an outgrowth of narrow legal questions. Haldane confessed this in John Deere Plow Company v. Wharton (1915): ${ }^{16}$ "it is the wise course to decide each case which arises without entering more largely upon an interpretation of the statute than is necessary for the decision of the particular question in hand." (Dawson 1933, 442) In the previous chapter, I quoted historian J.R. Miller's contention that judicial bias to the written word impoverishes their consideration of context. ${ }^{17}$ It was precisely this lack of historical and political context that led a

\footnotetext{
${ }^{15}$ re Board of Commerce Act and Combines and Fair Prices Act (1922) A.C. 191 at 197-201, excerpted in Beck 1971, 126-127

16 John Deere Plow Company v. Theodore F. Wharton (1915) A.C. 330, excerpted in Dawson, 1933, 441-42

17 “[L]egal training shapes litigators and judges who are focused on the written word, in contrast to historians' training, which brings them to believe that the written word without its context is literally meaningless. [...] I am not referring to the distinction between written and oral evidence, but text and context. [...] In complex Aboriginal
} 
new generation of Canadian political scientists to reject compact theory as advanced by the Judicial Committee.

\section{The Rejection of Compact Theory}

The 1930s ushered in two important changes in Canadian public policy. First, the Great Depression underscored the need for federal interventions in the economy beyond the scope of what individual provinces could undertake. The decentralizing vision of compact theory quickly became an obstacle in the push for more centralized economic and social policies. Second, the adoption of the Statute of Westminster in 1931 gave greater independence to British Dominions. This independence brought the issue of constitutional amendment to the fore, and without an amending formula in the BNA Act, it would follow from compact theory that every province would be required to consent to an amendment. (Grammond 2016a, 806)

Political scientist Norman Rogers presented a seminal paper to the Canadian political science association in 1931 which heavily criticized the notion that the compact between the provinces and the Dominion government could be considered a "treaty", as proponents of the compact suggested. To summarize his points of contention, Rogers argued that the British North American colonies, as subordinate units within the Empire, held no formal treaty-making authority. ${ }^{18}$ Similarly, the British North America Act was an Imperial statute imposed by the British Parliament, just as the Constitutional Act had been before and the Union Act after that. In Rogers's view, the BNA Act could not legally be considered a treaty because the provinces could

\footnotetext{
law cases, the limitation imposed by legal orientation to the written word can have severe consequences." (Miller 2013a, 8 emphasis added. See Chapter 2, Section E for greater discussion)

${ }^{18}$ Conservative scholar Tom Flanagan has used a similar argument to question the validity of Crown-Indigenous treaties, arguing that Crown negotiators had no authority to speak on behalf of the Crown, nor did Indigenous nations meet Westphalian definitions of the nation-state. (Flanagan 2000)
} 
not authorize the abandonment of the constitutional documents previously imposed. Were it a treaty, Rogers contended, then all parties to it would have to ratify it. Only the Dominion Parliament ratified the 1864 Quebec Resolutions, and the BNA Act rested upon the 1866 London Resolutions which only the New Brunswick and Nova Scotia legislatures ratified under pressure from London. In sum, Rogers argued that Confederation did not meet the legal criteria to be considered a treaty, which in his view reduced compact theory to a rhetorical tool of provincial politicians. (McLeod Rogers 1931; see also Livingston 1956; Romney 1999; Grammond 2016)

Following Rogers's lead, other English-Canadian political scientists such as F.R. Scott continued to argue that the JCPC had distorted the shared jurisdiction that had been envisioned in the pre-Confederation resolutions at Quebec and London: "this [property and civil rights] clause has been built up by judicial decision until it has become the effective residuary clause of the constitution in peace-time [...] It is a remarkable example of judge-made law." ${ }^{19}$ Likewise, Vincent MacDonald argued:

[O]ur Constitution, as it now exists in a text encrusted with decisions, is not what we sought or what the Imperial Parliament provided for us. It is history that [...] the Privy Council has not been a protector of minority rights so much as it has been a protector of provinces, and in that endeavor has distorted the whole scheme of legislative powers in the process of judicial fabrication of a constitution alien to that desired and enacted. [...] [T] hereby [the Privy Council] has left us with a Constitution ill-adapted to governance under present conditions and modes of thought. (MacDonald 1951, 1031, 1035; see also Beck 1971, 136-37)

On the subject of the inter-governmental cooperation proposed in the 1937 Natural Products Marketing case, MacDonald retorted: "jurisdiction and practical ability have been so divorced as to require ad hoc inter-governmental arrangements to close the gap. Our ship of state is indeed

\footnotetext{
${ }^{19}$ Scott, Frank R. 1947. "The Special Nature of Canadian Federalism" Canadian Journal of Economics and Political Science 13: 18, excerpted in Beck, 1971, 131
} 
one of 'divided compartments" ${ }^{20}$ and one in which the compartments have been divided in a way which impairs its ability to sail 'on the larger ventures' the changing world now requires." (MacDonald 1951, 1033)

Critics of the JCPC argued that the Committee had viewed Sections 91 and 92 in isolation of other constitutional provisions which allow for federal interference in areas of provincial jurisdiction. ${ }^{21}$ They also contended that in the Local Prohibition case, Lord Watson departed from the precedents on Ontario liquor law set by the Parsons and Russell cases.

Watson's literal reading of Sections 91 and 92, therefore, failed to comply with the common law tradition of stare decisis - trying like cases alike. (MacDonald 1951, 1032, 1036; Greenwood 1974, 254; see also Dawson 1933, 445) Greenwood cites a passage from Lord Watson's decision in Local Prohibition:

It was observed by this Board in Citizens' Insurance Co. of Canada v. Parsons that the paragraph just quoted 'applies in its grammatical construction only to No. 16 of s.92.' The observation was not material to the question arising in that case, and does not appear to their Lordships to be strictly accurate. It appears to them that the language of the exception in s.91 was meant to include and correctly describes all the matters enumerated in the sixteen heads of s.92, as being, from a provincial point of view, of a local or private nature. (as quoted in Greenwood 1974, 254)

Despite the reservations of legal and constitutional scholars, the provinces themselves continued to advocate on behalf of a provincial compact at least until the 1920s. (Livingston 1956, 50; Beck 1971, 120; Cody 1977, 61-65; Vipond 1989, 21; Romney 1999, 27) In 1937 uncertainty over jurisdiction in Depression-era policymaking led to the establishment of a Royal

\footnotetext{
${ }^{20}$ Here MacDonald is paraphrasing the Labour Convention case (1937) A.C. at 354

${ }^{21}$ F. Murray Greenwood, for instance, cites Section 92(10)(c) of the BNA Act, which allows for the nationalization of provincial public works projects, or Section 93(4), which allows for the federal imposition of education policies. (Greenwood 1974, 252)
} 
Commission on Dominion-Provincial Relations (also known as the Rowell-Sirois Commission, after its two chairs). In its brief to the Commission, the Government of New Brunswick held that:

The provinces, being sovereign and independent nations under the British Crown, jointly an unanimously arranged with the Imperial Government to provide an agency by means of which certain matters of common interest were to be dealt with. The agency [of the Dominion Parliament] was created by the provinces, and the provinces were not created by the agency. The provinces remained sovereign nations, and the British North America Act did not effect any change in their status. They are still independent sovereignties, and the Dominion is still the agency through which certain matters are to be administered. This has been more particularly demonstrated by the decisions of the Judicial Committee of the Privy Council. (New Brunswick and Canada: Royal Commission on DominionProvincial Relations. 1938, 100; Mallory 1941, 345-46)

The Rowell-Sirois Commission released its report in 1940. Taking inspiration from the Australian constitutional model, it suggested that government functions could be transferred or delegated from one government to the other, and that this could be done on a province-byprovince basis depending on their capacity. It was also the first time that equalization payments were contemplated as a way of levelling the provision of social services between the provinces. (Cody 1977, 70) Nevertheless, the transfer of jurisdiction would have necessitated a constitutional amendment at a time when there was no accepted amending formula. A DominionProvincial Conference was called in 1941, but fell apart after two days when Ontario, Alberta, and British Columbia refused to consider the Commission's recommendations as a basis for negotiation. (Livingston 1956, 86-87) Further discussion on amending the constitution was delayed indefinitely by the Second World War, and would not be taken up again until the 1970s.

Norman Rogers and his intellectual allies set out to prove that no compact between the federal and provincial governments existed, because the BNA Act could not be considered a treaty. But J.R. Mallory contends, much like the New Brunswick brief cited above, that the "imposition" of the BNA Act was in fact merely an implementation by the Imperial Parliament 
of a pre-existing agreement among the provinces to create the Dominion. If the provinces could conclude such an agreement among themselves, then this implies substantial political independence. (Mallory 1941, 345) Likewise, Grammond points out that the Imperial Parliament did not force Confederation on its North American colonies. Each was left to join of its own volition - Newfoundland, for instance, did not join until 82 years later. (Grammond 2016a, 804)

Are there aspects of compact theory which more closely reflect the nature of Confederation than others? George F.G. Stanley argues that the provincial compact was never marked by unanimity or consistency across Canadian provinces, and that "the popularity of the pact idea seems to vary in some provinces in inverse ratio to their fiscal need."(Stanley 1956, 23; see also Mallory 1941, 343) By contrast:

The Ontario-Quebec axis has transcended both time and political parties. [...] It has always been the buttress of provincial autonomy.[...] If the population of Canada were one in race, language, and religion, our federation would be marked by flexibility; amendment would be a comparatively easy matter where there was agreement on fundamental issues. Since history has given us [...] diversities of race and language, we must maintain a precarious balance between [...] groups; and our constitution is rigid and inflexible.(Stanley 1956, 24-25)

Stanley's argument suggests that the intercultural features of national compact theory are better established in Canadian constitutional history than the identification of exclusive jurisdiction. Compact is perhaps best described as a metaphor for government-to-government relationships, as will be discussed in the following section. It is this metaphor which has contributed to the revival of compact theory in an Indigenous context.

\section{The Legacy and Re-emergence of Compact Theory}

Despite the criticism of their interpretation, JCPC jurisprudence has had an enduring legacy in Canadian federalism. Chief among them is the view that provincial governments are 
equally as sovereign in their areas of jurisdiction as the federal government is in its areas. Thus students of Canadian law and policy often speak of "orders" of government and not "levels." As discussed below, this language becomes useful when discussing the inherent self-government rights of Indigenous governments in Canada.

After Patriation, a new generation of scholars began to examine the JCPC critics of the 1930s, 40s, and 50s. Paul Romney accuses centralist scholars of forgetting the historical underpinnings of Confederation. This was worsened, Romney argues, by the lack of an amending formula in the BNA Act, which allowed both Ottawa and the provinces to make exaggerated claims about their influence. Nevertheless: "In weighing the historical validity of the provincial compact theory we should remember that, though Canadians had quarreled over the implications of the Confederation compact almost from the start, the resulting uncertainty had not stopped the theory from becoming an axiom of Canadian constitutionalism" (Romney 1999, 36) Similarly, Mallory argues "The importance of political ideas lies not only in their validity, but in how widely they are believed to be true.”(Mallory 1941, 342)

This belief, it would appear, is at the heart of compact theory. Grammond argues that having an enforceable contract was never really the point of the compact idea. The constitutional text, for Grammond, translated the substance of a political accord so that it was recognizable to everyone. In other words, it describes the agreement between political forces, and the text should be interpreted in light of that agreement, not the reverse. Compact theory, then, is a metaphor in the sense that it carries a normative force. Based on the moral premise that one should keep one's promises, this normative force requires the parties to adhere to core principles such as federalism, the preservation of political units within the compact, and the protection of minorities. (Grammond 2016a, 800-802, 810-11; see also Pigeon 1951, 41-43) This 
interpretation has striking parallels to the Honour of the Crown as would be later applied to Indigenous rights law.

Grammond points, for instance, to the Numbered Treaties, and the "surrender and extinguishment" clauses they contain, which while featured in the text, do not reflect the understanding of Indigenous signatories. (Grammond 2016a, 818) As such, the Supreme Court has tried to "repair" the compact rather than declare it void, by applying concepts such as the fiduciary relationship between Indigenous people and the Crown, (Guerin v. The Queen, 1984) or admitting oral evidence to provide context for the agreement. (Delgamuukw v. British Columbia, 1997). Grammond also cautions that that understanding the original intent of the agreement should not prevent adaptation of the compact to respond to new policy requirements not anticipated in the original accord (Grammond 2016a, 822; see also MacDonald 1951, 1029) an accusation which, as seen above, was frequently levelled at the JCPC. John Borrows has similarly argued against an originalist understanding of Aboriginal rights which confines selfgovernment to its pre-Contact expression, without adapting the sharing relationship embodied in treaties to a contemporary policy context. (see Borrows 1997a; 2012; 2017a)

The 1963 Royal Commission on Bilingualism and Biculturalism began to shift Canada's self-image from a country of two founding nations to many, an image later made official by Pierre Trudeau's multiculturalism policy of 1971. (Grammond 2016a, 808) This shift was a blow to the national compact theory, but as constitutional talks continued throughout the $1970 \mathrm{~s}$ in the lead-up to Patriation, the unique place of Quebec became increasingly obvious, not least because of the rise of René Lesvesque's pro-secession Parti Québécois. Grammond posits that the failure to include Quebec in ratifying the Constitution Act, 1982 contributed to the argument that the 
national compact had been broken (Grammond 2016a, 809) - something that Ottawa tried to remedy in both the Meech Lake and Charlottetown Accords.

National compact theory provides students of the Canadian constitution with a history of agreement based on a set of consensual relationships, with high courts as the arbiter. Grammond remarks that this is strikingly similar to the constitutional relationship at the heart of treaty federalism, (Grammond 2016a, 806) a point echoed by Brian Slattery:

In effect, the Court's account draws parallels between the process whereby the provinces entered the federal union, and that whereby Aboriginal peoples became partners in Confederation. In both cases, the Crown usually proceeded by way of negotiation and agreement, a route not without its difficulties and conflicts. In both cases, it made solemn promises in order to secure the other party's agreement to enter Canada. In both cases, the resulting pact was embodied in fundamental constitutional accords - termed "Constitution Acts" in the case of provinces, "Treaties" in the case of First Nations. (Slattery 2014, 330)

Based on these agreements, Slattery argued that the Crown developed a fiduciary or trustlike relationship with the provinces, just as it developed a fiduciary relationship with Indigenous peoples:

[T] he division of powers between the Federal Government and the Provinces constitutes a fiduciary structure under which regional communities are guaranteed a large degree of autonomy over their own affairs, without the possibility of outside interference. By the same token, the structure embodies a commitment to the larger community of Canada that its transcending interests will not be a prisoner of regional outlooks but will be furthered by Parliament. [...] But the division of powers is not the only collective manifestation of the constitutional trust. I suggest that the Constitution incorporates a particular fiduciary relationship with the Province of Quebec. This relationship is grounded in various historical acts and practices that cumulatively have recognized the right of the largely francophone community of Quebec to retain its distinctive laws, religion, language, and culture, and to live under a separate government with powers sufficient to sustain the society's unique character. [...] The third collective facet of the Canadian constitutional trust is the special fiduciary relationship between the Crown and Aboriginal peoples, recognized by the Supreme Court. This relationship is grounded in historical practices that emerged from dealings between the British Crown and the Aboriginal nations in eastern North America. (Slattery 1992, 270-71) 
Slattery argues that the guarantees provided by the Royal Proclamation, the Treaty of Niagara and other treaties enshrine a quasi-federal structure to the Crown-Indigenous relationship, where Indigenous nations continue to operate as their own distinct polities while living under Crown protection. If the Quebec Act was the "Magna Carta" for French Canada, (Stanley 1956, 3) then the Royal Proclamation was the Magna Carta for Indigenous Canada. (Slattery 2014,327-28) Slattery also notes that because of their status as constitutional entities, Indigenous polities are not distinguished by racial or ethnic difference (Slattery 1992, 273), as some non-Indigenous politicians have believed. This belief glosses over traditional practices of admitting outsiders through kin-making, as well as the diversity internal to Indigenous nations.

The key difference, of course, between the provincial/national compact and the CrownIndigenous compact ${ }^{22}$ is the source of sovereignty. Where the Canadian provinces were guaranteed independence and autonomy by delegation from the British Crown, (Pigeon 1951, 36) Indigenous nations hold this autonomy inherently as established polities allied with the British Crown. Indigenous sovereignty is not granted, but merely under Crown protection. As Grammond has noted, Canada is a country with more than one underlying compact, and different political communities within the country have and will continue to require different political arrangements.(Grammond 2016a, 817)

During Canada's lengthy period of constitutional reform between the late 1970s and early 1990s, Indigenous activists brought the Crown-Indigenous compact back to the fore.

\footnotetext{
${ }^{22}$ The opening passages of this chapter described compact theory as the free association of pre-existing political entities or cultures who continue to maintain their distinction within an ongoing political relationship. In an Indigenous context, this closely approximates the relationships represented in wampum belts such as the Covenant Chain and Two-Row Wampum, both of which were presented in the ceremonies surrounding the Treaty of Niagara in 1764. (see Borrows 1997e) Put simply, the Crown-Indigenous compact recalls the original treaty relationship and describes a system of shared sovereignty over territory while maintaining distinct jurisdictional spheres.
} 
Entrenchment of their rights in the written constitution was seen as a key avenue to protecting the treaty relationship. As we will see in the following sections, their efforts led to the addition of Section 35 to the Constitution Act, 1982, but further constitutional talks over the next decade failed to produce more specific provisions on Aboriginal and treaty rights, leaving the content of Section 35 largely up to judicial interpretation. (McNeil 2001, 171)

\section{E. The Crown-Indigenous Compact and Patriation}

One of the earliest reassertions of Indigenous nationhood in the modern era came with the Dene Declaration of 1975. (Sanders 1983a, 302; Zlotkin 1984, 4; "The Dene Declaration" [1975] 1976) However, the Crown-Indigenous compact can be traced back as far as the fur trade, (see Miller 2018) and has arguably been constitutional in nature since the Royal Proclamation.

(Sanders 1983c, 324; see also Borrows 1997e) But as constitutional reform was being contemplated in Canada during the late 1970s, politicians were either ignorant of, or hostile to the notion of Indigenous nations as a distinct constitutional order. Ottawa's response was to deal with Aboriginal and treaty rights through legislation, as it assumed the authority to do under Section 91(24) of the British North America Act. (Sanders 1983a, 303, 307, 326-27) Thus in 1978 the National Indian Brotherhood (NIB) identified specific constitutional entrenchment as a priority for the protection of Indigenous rights and treaty agreements. (Sanders 1983a, 304; 1983c, 321; Zlotkin 1984, 4)

In February 1979 the (then) three national Indigenous organizations, ${ }^{23}$ were invited as observers to a meeting of First Ministers, but were shut out of closed-door sessions. Though the

\footnotetext{
${ }^{23}$ These were the (1) National Indian Brotherhood, the forerunner to the Assembly of First Nations, representing Status Indians, (2) the Native Council of Canada, representing the Métis and non-Status Indigenous peoples, and (3) the Inuit Committee of National Issues, the forerunner to Inuit Tapiriit Kanatami
} 
Minister of Justice invited the NIB to participate in the fall meeting of the Continuing Committee of Ministers on the Constitution, national politics soon intervened and put Indigenous issues on the back burner. In May the Liberal government of Pierre Trudeau was ousted by Joe Clark's Progressive Conservatives, who were soon toppled again by the Liberals in February 1980. In May 1980 Quebec held its first referendum on sovereignty, and it was not until June of that year that the Committee produced a shortlist of 12 constitutional items to be presented at the next First Ministers' meeting. Indigenous rights did not make the shortlist. (Sanders 1983a, 305, 3089)

By October 1980, the federal government's unilateral Constitutional Amendment Bill, Bill C-60, contained a limited clause to protect the "rights and freedoms that pertain to the native peoples of Canada" from the proposed Charter of Rights and Freedoms. (Zlotkin 1984, 4) But

Ottawa's unilateral approach to amending the constitution deeply alienated provincial governments. Facing lukewarm political support for Patriation, the federal government tried horse trading over an Aboriginal rights clause. They sought the backing of the NIB and provincial premiers receptive to Indigenous rights advocacy, such as then New Democratic Premier of Saskatchewan, Allan Blakeney. In January 1981 then Minister of Justice Jean Chrétien introduced amendments strengthening Charter exemptions for Aboriginal and treaty rights in what would become Section 25. In addition, the resolution introduced a new Section 34, reading:

34(1) The aboriginal and treaty rights of the aboriginal peoples of Canada are hereby recognized and affirmed.

(2) in this Act, "aboriginal peoples of Canada" includes Indian, Inuit and Métis peoples of Canada.(Sanders 1983a, 315) 
Though it had the support of the NIB, the new constitutional section was silent on Indigenous demands for the recognition of self-government, and a consultation clause on future amendments. Further discussion of Aboriginal and treaty rights was pushed to post-Patriation conferences, outlined under Section 37 of the amended bill. (Sanders 1983a, 314-15; 1983c, 324; Zlotkin 1984, 4-5)

In September 1981, the Supreme Court released its judgment in Re: Resolution to amend the Constitution, also known as the Patriation Reference. In it, the Court held that while the federal government had the legal right to unilaterally amend the Canadian constitution, there existed a common law convention which bound it to consult with provincial governments before doing so. (Zlotkin 1984, 5) Forced to negotiate by the Court, the federal government concluded the so-called November Accord with provincial governments, but the revised constitutional package omitted Section 34 from earlier that year, eliminating the recognition of Aboriginal and treaty rights. Both federal and provincial officials blamed one another for the deletion, neither wishing to publicly take responsibility. (Sanders 1983a, 319; 1983c, 315; Zlotkin 1984, 5)

In October of that year the Union of B.C. Indian Chiefs (UBCIC) organized a protest train called the "Constitution Express", which was slated to travel from Vancouver to Ottawa in time both parliamentary hearings on the constitutional proposal before a Special Joint Committee, as well as an emergency assembly of First Nations organized by the NIB. Shortly after the November Accord was concluded, five hundred First Nation representatives arrived in Ottawa aboard the Constitution Express. Two thousand delegates attended the NIB assembly, in which a statement on self-determination was drafted and presented to the Governor General. The Special Joint Committee invited representatives of both the NIB and the Constitution Express, but these leaders chose at the last minute to boycott the hearings. The Committee did, however, 
hear testimony from the other two national Indigenous organizations - the NCC and ICNI - as well as the Nisga'a nation and the Council for Yukon Indians. (Sanders 1983a, 311-13; see also Manuel and Derrickson 2017b)

Organizers from BC, Saskatchewan and Alberta also sent delegates to Europe in November. This marked the sixth time in two years First Nations representatives had travelled to London, having already met with British Opposition leaders and members of the House of Lords in 1980. (Sanders 1983a, 306) A First Nation delegation from Quebec met with French officials in Paris, and a delegation from Alberta met with the Pope. (Sanders 1983a, 319)

Indigenous activism managed to sway some provincial premiers. On November $17^{\text {th }}$ Howard Pawley defeated Sterling Lyon as Premier of Manitoba, committing in the election for the restoration of Section 34. Two days later, Premier Blakeney of Saskatchewan, facing opposition for his failure to support gender equality provisions, agreed to support gender equality if other premiers supported Section 34. Within days the premiers of Ontario, British Columbia, and Alberta each agreed to support a modified constitutional provision recognizing and affirming "existing" Aboriginal and treaty rights - now rebadged as Section 35. (Sanders 1983a, 321; Zlotkin 1984, 5)

While constitutional debates continued, Indigenous activists from BC, Alberta, and Saskatchewan launched three separate lawsuits in England. Given their concerns that first ministers were, at best, wavering in their support for safeguarding Aboriginal and treaty rights in the Constitution, Indigenous advocates looked to the relationship with the British Crown. They argued that the consent of Indigenous peoples was necessary for Patriation. As Douglas Sanders observed: 
Canada, the argument went, did not have a free hand to terminate Indian rights so long as the treaty link to the United Kingdom existed and so long as the constitution contained its one provision on Indians, section 91(24) of the BNA Act. Patriation would both sever the treaty link and enable Canada to repeal that section. (Sanders 1983a, 322)

The Alberta case was dismissed by the Court of the Queen's Bench in December 1981, but the Court of Appeal agreed to hear the case. The Thatcher government delayed the second reading of the Canada Bill until the Alberta association received a judgment in their appeal. The verdict was delivered on January $28^{\text {th }}$. Lord Denning of the Court of Appeal ruled that the Crown in Right of the United Kingdom had been split (though he did not say when) from the Crown in Right of Canada, and that treaty law fell under Canada's purview. (Sanders 1983a, 323) A similar lawsuit had been launched in Canada by the UBCIC back in September, but was not actively pursued based on the presumption that the treaty order was a matter of Imperial law and not Canadian law. (Sanders 1983a, 311, 317) Lord Denning's ruling was a blow to Indigenous consent, but Indigenous activism both nationally and internationally had not gone unnoticed by policymakers. The Federation of Saskatchewan Indians reported that of the debate time allotted to the Canada Bill in the British Parliament, approximately $90 \%$ of the debate in the House of Commons and $80 \%$ of the debate in the House of Lords related to Indigenous rights issues. (Sanders 1983a, 323; Zlotkin 1984, 6) Queen Elizabeth, upon signing the newly patriated constitution on April $17^{\text {th }}, 1982$, noted in her speech that "the rights of the aboriginal people are recognized with full opportunity for further definition." (Sanders 1983a, 324) This was not an inconsiderable victory. The first iteration of Section 35 rights was now constitutionally recognized and affirmed. It would be the work of constitutional conferences over the next decade to try to further define the content of that "box of rights." 


\section{F. Constitutional Conferences, 1983-1992}

The first such conference took place the following year in March 1983. The conference took place over a mere two days, but had an ambitious agenda relating largely to Indigenous issues. On the shortlist of constitutional items were (1) the entrenchment of an Aboriginal Charter of Rights, (2) an Aboriginal consent clause for future constitutional amendments, (3) self-government, (4) the repeal of key sections requiring provincial consent for the establishment of new provinces, (5) adjustments to equalization payments to provide for the financing of Aboriginal governments, and (6) provision for further First Ministers' conferences to discuss the implementation of Aboriginal and treaty rights.

The amending formula agreed to in the Constitution Act, 1982 required the consent of at least two-thirds of the provinces representing at least $50 \%$ of the Canadian population. The notion of an Aboriginal consent clause would require changing the amending formula itself $-\mathrm{a}$ process which would require unanimous consent among the provinces. At issue was Premier René Lévèsque of Quebec, who, not having been signatory to the patriated constitution the previous year, refused to consider tabling any amendments in Quebec City, as this would recognize the application of the Constitution Act to Quebec. (Zlotkin 1984, 7-9; Schwartz 1986, 132) Trying to circumvent the difficulty posed by changing the amending formula, the draft consent clause tabled by the federal government stated that federal and provincial governments were "committed to the principle" of holding a conference prior to amending provisions relating to Aboriginal rights. But this kind of vague language would be entirely non-justiciable, (Schwartz 1986, 127) and the issue of Indigenous consent would again be pushed to future constitutional conferences. 
Douglas Sanders argued that the addition of a consent clause would not have been a major departure from federal government practice since the Second World War, pointing to Indigenous consultations conducted in the lead-up to the 1951 amendments to the Indian Act, testimony before the Hawthorne Commission in the mid-1960s, and the withdrawal of the 1969 White Paper following a backlash by Indigenous activists. (Sanders 1983c, 335-36) Missing from Sanders's argument, however, is that these past consultations had been taken as purely advisory by the federal government, and that a constitutional consent clause would hold nonIndigenous governments to a higher legal standard to which they were unwilling to commit.

The spectre of Quebec sovereignty had also loomed large since the beginning of constitutional talks in the late 1970s. Just as Indigenous peoples wanted to be identified as distinct and bearing their own right to self-determination, so too did Quebec nationalists, and federalist politicians were unwilling to distinguish between Québécois and Indigenous visions of sovereignty at a time when they feared for the future of the federation. (Sanders 1983c, 337) In his 1978 testimony before the Task Force on Canadian Unity, Noel Starblanket, then president of the National Indian Brotherhood, stated:

The federal government has continually hammered the Indian people with as much vigour as it had the Parti Québécois. In Ottawa's minds, a move to undermine the special status of Indians is a move to undercut the special status of Quebec. The Indian people greatly resent this government's willingness to fight the Parti Québécois on the backs of the Indian people. (Sanders 1983a, 304)

Relating to other issues on the agenda of the 1983 conference, the rebranded Assembly of First Nations tabled a proposal to finance Indigenous governments, but it received little attention and no amendment on the subject was tabled. (Schwartz 1986, 209-10; see also Long, Little Bear, and Boldt 1984, 80) Still, some important advancements were made over the two-day 
conference. Two new subsections were added to Section 35 . The first extended "treaty rights" to modern land claim agreements, and the second guaranteed the application of Aboriginal and treaty rights equally to male and female persons. The remainder of the agenda would be broached again the following year.

In the intervening months, the Special Committee on Indian Self-Government published its report, known as the Penner Report after the committee's chairman, Keith Penner, in October 1983. Among its recommendations was to do away with a legislative approach to Aboriginal rights and entrench the right to self-government in the constitution. The report argued that selfgovernment was an essential element of a renewed relationship with Indigenous peoples, and it marked the first time a government document identified self-government as an "inherent" right. (Schwartz 1986, 149-52; Zlotkin 1984, 12; see also Long, Little Bear, and Boldt 1984, 69; Abele, Graham, and Maslove 1999)

Armed with the conclusions of the Penner Report, Indigenous advocates were prepared to table constitutional amendments relating to self-government, but once again national politics intervened in constitutional talks. One week before the 1984 conference, Pierre Trudeau announced his retirement as Prime Minister and his intention to call an election before the end of the year. Before the conference even began, it was unlikely that provincial premiers would reach agreement with an outgoing federal government. (Zlotkin 1984, 11)

The 1984 conference was made up of four working groups, organized around the topics of (1) equality rights, (2) Aboriginal rights, Aboriginal title, treaties and treaty rights, (3) land and resources, and (4) Aboriginal self-government. The federal government proposed the addition of a new constitutional section, 35.2, which would state the following: 
35.2 Without altering the legislative authority of Parliament or of the provincial legislatures, or the rights of any of them with respect to the exercise of their legislative authority,

(a) Parliament and the legislatures, together with the government of Canada and the provincial governments, are committed to

(i) preserving and enhancing the cultural heritage of the aboriginal peoples of Canada, and

(ii) respecting the freedom of the aboriginal peoples of Canada to live within their heritage and to educate their children in their own languages, as well as in either or both of the official languages of Canada;

(b) the aboriginal peoples of Canada have the right to self-governing institutions that will meet the needs of their communities, subject to the nature, jurisdiction and powers of those institutions, and to the financing arrangements relating thereto, being identified and defined through negotiation with the government of Canada and the provincial governments; and

(c) the government of Canada and the provincial governments are committed to participating in the negotiations referred to in paragraph (b) and to presenting to Parliament and the provincial legislatures legislation to give effect to the agreements resulting from the negotiations. (Zlotkin 1984, 26)

By stating that the federal and provincial governments were "committed to" cultural and self-government institutions, and by making the jurisdiction and finance of these contingent upon negotiation, the proposed amendment was legally unenforceable, and negated the inherent nature of self-government rights. Added to this was the fact that only three provincial governments Manitoba, Ontario, and New Brunswick - supported the federal proposal, which doomed it to failure. Despite much discussion, no amendments were agreed to at the 1984 conference, and Indigenous self-government would make no further constitutional gains. (Zlotkin 1984, 12-15, 19; Schwartz 1986, 255) A further two conferences in 1985 and 1987 would also see amendments tabled entrenching the inherent right to self-government, with neither proposal gaining enough support to be adopted. (McNeil 2001, 170-71)

The outcome of the 1987 conference, the Meech Lake Accord, was designed to win Quebec's acceptance of the Constitution Act, 1982, but contained no further provisions on 
Aboriginal rights. The Accord was sent to provincial legislatures for ratification before a deadline of June 1990. Manitoba MLA and Oji-Cree activist Elijah Harper used procedural delays at least eight times to prevent a vote on the Meech Lake Accord, on the grounds that it failed to include Aboriginal rights. The resistance of Elijah Harper played a key role in the ultimate demise of the Meech Lake Accord, and forced governments to regroup in Charlottetown in 1992 for a final round of constitutional negotiations. (McNeil 2001, 172)

Among the amendments considered at Charlottetown was the addition of the so-called "Canada Clause", which formally recognized Indigenous peoples as the first peoples to govern the territory of Canada, and so recognized them as one of three orders of government in Canada. The recognition was further confirmed in a new proposed Section 35.1, which stated:

35.1 (1) The Aboriginal peoples of Canada have the inherent right of selfgovernment within Canada.

(2) The right referred to in subsection (1) shall be interpreted in a manner consistent with the recognition of the governments of the Aboriginal peoples of Canada as constituting one of three orders of government within Canada. (McNeil 2001, 175)

But further proposed amendments contained language which threatened to weaken the right of self-government. Subsection 35.1(3) recognized Aboriginal governments as the elected legislative bodies of Aboriginal peoples, leaving no constitutional room for customary law unless those laws were codified in legislation. Subsection 35.2(1) once again committed negotiating the jurisdiction of Aboriginal governments, but offered no language to indicate that the agreements resulting from those negotiations would receive constitutional entrenchment. Subsection 35.4(2) would have invalidated any Indigenous law that "may be inconsistent with federal or provincial laws that are essential to the preservation of peace, order and good government in 
Canada"(McNeil 2001, 176), leaving a wide scope for the interpretation of laws "essential" to good government.

Despite these shortcomings, the Charlottetown Accord enjoyed broad support among the Métis and Inuit. First Nations, by contrast, expressed concern that the proposals had been rushed, and not enough time had been left to translate them into local languages for community consultation. The Accord included a variety of other proposed amendments, notably with particular considerations for Quebec, and went to a vote in a national referendum in October 1992. While $55 \%$ of the national electorate rejected the constitutional package, fully $62 \%$ of Status Indians voted against it. (McNeil 2001, 182; see also Campbell and Pal 1994; Nahwegahbow 2002; Abele and Prince 2006)

After ten years of constitutional talks, the substance of Section 35 rights remained effectively unchanged since the first post-Patriation conference in 1983. Can we conclude that the inherent right of self-government has gone unrecognized? Scholars of Indigenous rights such as Brian Slattery argue no - Section 35 entrenches self-government as an "existing" right, only implicitly rather than explicitly. Indigenous sovereignty, Slattery argues, owes its existence to prior occupation, and not the Indian Act or other Canadian legislation. Because self-government was never lawfully extinguished, it endures as an "existing Aboriginal right." (Slattery 1992, 262, 279, 281; see also Sanders 1983c, 330) Section 35 carries with it the potential for the internal decolonization of Canada. (Slattery 1992, 272) As stated succinctly by Kiera Ladner: "[Section 35] raises the possibility of decolonization because [...] the constitution not only affords protection to Indigenous constitutional orders but it incorporates their recognition through Aboriginal and treaty rights - into, and reconciliation with, the Canadian constitutional order" (Ladner 2006b, 15) 
But because Section 35 offers few specifics regarding which Aboriginal and treaty rights "exist", and because of the repeated failure of political accord to offer that definition, the task is left to the judiciary to interpret its content, in much the same way that the judiciary interpreted the content of Sections 91 and 92 of the BNA Act. But this interpretation takes time, and is the product of many years of litigation. In an oddly prescient passage from their 1984 book on selfdetermination, Long, Little Bear, and Boldt remarked that:

One consideration is the uncertainty over the meaning of aboriginal rights within the amended Constitution. If the demand for Indian self-government cannot be met until aboriginal rights are defined, years might pass before any significant degree of Indian self-government can be realized or long-term solutions to pressing matters [...] can be found. (Long, Little Bear, and Boldt 1984, 71)

\section{G. The Risks of Defining Constitutional Rights}

Despite the struggle of Indigenous advocates to further define Section 35 rights in the decade after Patriation, this final section examines how the inclusion of explicit constitutional provisions on the nature of Aboriginal and treaty rights could prove a double-edged sword; and perhaps the assertion of a "full box of rights" under Section 35 is better served by the judicial interpretation of more general provisions.

With the landmark Calder v. B.C. case of 1973 which precipitated Ottawa's Comprehensive Claims policy, the Supreme Court asserted that where no treaty had been signed ceding title to the Crown, Aboriginal title to the land remained intact. (Calder et al. v. AttorneyGeneral of British Columbia 1973) This triggered a great deal of uncertainty among settler governments, who were forced to confront the fact that the Crown sovereignty asserted over Canadian territory might not equate to jurisdiction over that territory. (Blackburn 2005, 590; 2007, 624; Pasternak 2017, 7, 15; see also McNeil 2010; Dodds 2012) 
This realization produced uncertainty for settler governments' economic interests. At issue was (and still is) the use of land, in particular its use for resource extraction, and competing claims for jurisdiction over the land. (Coulthard 2014, 60) The strategy of the Canadian state has historically been to delegitimize inherent Indigenous jurisdiction by limiting their rights to preContact practices, and to replace it with delegated authority. (Pasternak 2017, 5; Starblanket 2019b, 14, 19-20) Carole Blackburn provides the example of the modern treaty signed by the Nisga'a nation in 2000. Her interviews with Nisga'a negotiators reveals that in order to avoid the "surrender and extinguishment" clauses of previous land claim agreements, the Nisga'a had to set out in the treaty every Aboriginal right of their people, outside of which no rights would be recognized by provincial and federal governments. (Blackburn 2005, 591-93)

Canada's continued recourse to siloed jurisdiction has troubling implications for the future adaptability of Indigenous governance - as it did for provincial rights - but the Nisga'a were able protect important political space; to reassert jurisdiction over their territory and reconstitute their nationhood. As Blackburn states:

Before the treaty the Nisga'a were classified as a series of Indian bands. They were entitled to a handful of small reserves held in trust by the federal government and lived under the regulatory apparatus of the federal Indian Act. The treaty means the Nisga'a Nation now owns 2,000 square kilometres of land; they also have much greater decision-making powers and governing jurisdiction because the treaty removes them from the Indian Act's legal purview. (Blackburn 2007, 622)

Herein lies the paradox of constitutional recognition. ${ }^{24}$ In the Patriation debates of the late 1970s to early 1990s, Indigenous advocates sought constitutional entrenchment to protect their rights in the face of government policies to eliminate them. At the same time, resistance to constitutional

\footnotetext{
${ }^{24}$ As a modern treaty, the Nisga'a agreement has constitutional status under Section 35(3) of the Constitution Act, 1982
} 
recognition can also assert Indigenous nationhood independently of the Crown, flowing from ancestral occupation. (Starblanket 2019b, 18-19)

As maintained throughout this dissertation, the treaty relationship and the constitutional link provided by Section 35 outline the allegiance of Indigenous nations to the Crown, not supplication to it. The advantage of having "existing" Aboriginal and treaty rights broadly defined in the Constitution Act, 1982 is that this preserves political space for Indigenous peoples to practice their own governance traditions. Further specification of Aboriginal rights in the constitutional text could risk judicial interpretation that further bounds the authority of Indigenous governments, as the JCPC did to the federal government over a century ago. The broad wording of Section 35 means that settler governments cannot presume the paramountcy of Crown sovereignty (Blackburn 2007, 631) and as such they look to the judiciary as an intermediary. As Walters states:

[T] he constitutionalization of aboriginal rights has been interpreted by judges as an invitation to reconsider the national constitutional narrative as it relates to aboriginal peoples so that the end of legitimacy might, over time, be achieved. [...] Instead of looking for native consent to Crown sovereignty where none existed, [one] approach taken by judges is to concede the moral frailty of Crown sovereignty, but then seek to remedy the problem by placing special duties upon the Crown in relation to aboriginal peoples. [...] The point underlying this reasoning is that because the foundations of Crown sovereignty are dishonourable, the Crown is therefore under a special constitutional obligation to make up for that fact by exercising its sovereignty with honour. (Walters 2006b, $500,512-13)$

In the next chapter, we will examine how the honour of the Crown as decribed in the Haida

Nation and Taku River cases and its legal extension, the duty to consult, served to impose such limits on the exercise of Crown sovereignty. 


\section{Conclusion}

This chapter has shown that judicial interpretation left an enduring legacy on the practice of Canadian federalism. Though judicial narratives of compact theory have fallen in and out of favour over time, they have provided a useful frame for understanding the distinct political cultures within Canada's federal compact, as well as a historical analog for co-equal sovereignties which can easily be applied to Indigenous rights. Indigenous advocates lobbied for nearly 15 years for the constitutional recognition of the Crown-Indigenous compact. While Section 35 provides the framework of that recognition, more specific constitutional provisions on the inherent right to self-government were struck down, leaving the content of Section 35 open to legal interpretation.

It is the work of political leaders to enter into agreement, but it is left to the judiciary to give shape to that agreement when disputes arise. Compounded over time, these decisions build a legal context which guides the implementation of the initial compact. As argued by Robert MacGregor Dawson, "The supreme statute must be defined, expanded, interpreted, and reinterpreted by judicial decisions; and hence the true nature of Canadian federalism is disclosed only through a long series of judgements.”(Dawson 1933, 431) In the following chapters, I will discuss how certain key cases of the Supreme Court of Canada - Haida Nation (2004), Taku River (2004), Mikisew (2005, 2018), Little Salmon-Carmacks (2010), and Grassy Narrows (2014) - have guided the implementation of the Crown-Indigenous compact, and how that implementation has been carried out in Ontario's consultations with First Nations. 


\section{References}

Abele, Frances, Katherine A. Graham, and Allan Maslove. 1999. "Negotiating Canada: Changes in Aboriginal Policy over the Last Thirty Years." In Shape Shifting: Canadian Governance Toward the 21st Century, edited by Leslie Pal, 1999-2000:251-92. Oxford University Press.

Abele, Frances, and Michael J. Prince. 2006. "Four Pathways to Aboriginal Self-Government in Canada." American Review of Canadian Studies 36 (4): 568-95.

Beck, J.M., ed. 1971. The Shaping of Canadian Federalism: Central Authority or Provincial Right? Issues in Canadian History. Toronto: Copp Clark Publishing.

Blackburn, Carole. 2005. "Searching for Guarantees in the Midst of Uncertainty: Negotiating Aboriginal Rights and Title in British Columbia." American Anthropologist 107 (4): 586-96.

. 2007. "Producing Legitimacy: Reconciliation and the Negotiation of Aboriginal Rights in Canada." Journal of the Royal Anthropological Institute 13 (3): 621-38.

Borrows, John. 1997a. "Frozen Rights in Canada: Constitutional Interpretation and the Trickster." American Indian Law Review 22 (1): 37-64.

1997b. "Wampum at Niagara: The Royal Proclamation, Canadian Legal History, and Self-Government." In Aboriginal and Treaty Rights in Canada, edited by Michael Asch, 170. UBC Press. http://www.chiefs-ofontario.org/sites/default/files/files/Borrows-WampumAtNiagara\%20(2).pdf.

_. 2012. “(Ab)Originalism and Canada’s Constitution.” Supreme Court Law Review 58: 351-98.

. 2017. "Challenging Historical Frameworks: Aboriginal Rights, The Trickster, and Originalism.” The Canadian Historical Review 98 (1): 114-35.

British North America Act. 1867. http://www.justice.gc.ca/eng/rp-pr/csj-sjc/constitution/lawreg-loireg/p1t13.html.

Calder et al. v. Attorney-General of British Columbia. 1973 [1973] SCR 313. Supreme Court of Canada.

Campbell, Robert, and Leslie Pal. 1994. "The Rise and Fall of the Charlottetown Accord." In The Real Worlds of Canadian Politics: Cases in Process and Policy, 3rd ed., 142-210. Broadview Press.

Cody, Howard. 1977. "The Evolution of Federal-Provincial Relations in Canada: Some Reflections.” American Review of Canadian Studies 7 (1): 55-83.

Coulthard, Glen S. 2014. Red Skin, White Masks. Minneapolis: University of Minnesota Press.

Dawson, Robert MacGregor, ed. 1933. Constitutional Issues in Canada, 1900-1931. Oxford University Press.

Delgamuukw v. British Columbia. 19973 SCR 1010. Supreme Court of Canada.

Dodds, Klaus. 2012. "Graduated and Paternal Sovereignty: Stephen Harper, Operation Nanook 10, and the Canadian Arctic.” Environment and Planning D: Society and Space 30: 989-1010.

Flanagan, Tom. 2000. First Nations, Second Thoughts. McGill-Queen's University Press.

Grammond, Sebastien. 2016. "Compact Is Back: The Supreme Court Od Canada's Revival of the Compact Theory of Confederation." Osgoode Hall Law Journal 53: 799-823.

Greenwood, F. Murray. 1974. "Lord Watson, Institutional Self-Interest, and the Decentralization of Canadian Federalism in the 1890s." University of British Columbia Law Review 9 (2): 244-69, 274-79.

Guerin v. The Queen. 1984 [1984] 2 SCR 335. Supreme Court of Canada. 
Ladner, Kiera L. 2006. "Indigenous Governance: Questioning the Status and the Possibilities for Reconciliation with Canada's Commitment to Aboriginal and Treaty Rights." National Centre for First Nations Governance.

Livingston, William S. 1956. "The Amendment of the Canadian Constitution." In Federalism and Constitutional Change, 16-109. Oxford University Press.

Long, J. Anthony, Leroy Little Bear, and Menno Boldt. 1984. "Federal Indian Policy and Indian Self-Government in Canada." In Pathways to Self-Determination: Canadian Indians and the Canadian State, 69-84. Toronto: University of Toronto Press.

MacDonald, Vincent C. 1951. "The Privy Council and the Canadian Constitution." Canadian Bar Review 29: 102137.

Mallory, J.R. 1941. “The ‘Compact’ Theory of Confederation.” Dalhousie Review 21 (3): 342-51.

Manuel, Arthur, and Ronald Derrickson. 2017. The Reconciliation Manifesto: Recovering the Land, Rebuilding the Economy. Toronto: James Lorimer and Company Ltd.

McLeod Rogers, Norman. 1931. "The Compact Theory of Confederation.” In Proceedings of the Canadian Political Science Association, 205-30. Canadian Political Science Association.

McNeil, Kent. 2001. Emerging Justice? Essays on Indigenous Rights in Canada and Australia. Saskatoon: Native Law Centre, University of Saskatchewan.

. 2010. "Reconciliation and Third-Party Interests: Tsilhqot'in Nation v. British Columbia." Indigenous Law Journal 8 (1): 7-26.

Miller, Jim R. 2013. "Aboriginal-Crown Treaty-Making in Canada: A Many-Splendoured Thing." In A History of Treaties and Policies, edited by Jerry P. White, Erik Anderson, Jean Pierre Morin, and Dan Beavon, 7:3-12. Aboriginal Policy Research. Thompson Educational Publishing.

_ 2018. "Compact, Contract, Covenant: The Evolution of First Nations Treaty-Making." In Reconsidering Confederation: Canada's Founding Debates, 1864-1999, edited by Daniel Heidt, 19-51. University of Calgary Press.

Nahwegahbow, David C. 2002. "Recognition of Inherent Rights Through Legislative Initiatives.” In . Toronto, Canada: Indigenous Bar Association.

New Brunswick and Canada: Royal Commission on Dominion-Provincial Relations. 1938. Submission by the Government of the Province of New Brunswick to the Royal Commission on Dominion-Provincial Relations. Fredericton.

Pasternak, Shiri. 2017. Grounded Authority: The Algonquins of Barriere Lake against the State. Minneapolis: University of Minnesota Press.

Pigeon, Louis-Phillipe. 1951. "The Meaning of Provincial Autonomy.” Canadian Bar Review 29 (2): 35-46.

Romney, Paul. 1999. "Provincial Equality, Special Status, and the Compact Theory of Canadian Confederation." Canadian Journal of Political Science 32 (1): 21-39.

Sanders, Douglas. 1983a. "The Indian Lobby.” In And No One Cheered: Federalism, Democracy and the Constitution Act, edited by Keith Banting and Richard Simeon, 301-32. Methuen Publications.

—. 1983b. "The Rights of the Aboriginal Peoples of Canada." Canadian Bar Review 61: 314-38.

Schwartz, Bryan. 1986. First Principles, Second Thoughts: Aboriginal Peoples, Constitutional Reform and Canadian Statecraft. Montreal: Institute for Research on Public Policy.

Slattery, Brian. 1992. "First Nations and the Constitution: A Question of Trust." Canadian Bar Review 71 (2): 26193. 
—. 2014. "The Aboriginal Constitution." Supreme Court Law Review 67: 319-36.

Stanley, George F.G. 1956. “Act or Pact? Another Look at Confederation.” In Annual Report of the Canadian Historical Association, 11-25.

Starblanket, Gina. 2019. "Constitutionalizing (In)Justice: Treaty Interpretation and the Containment of Indigenous Governance.” Constitutional Forum 28 (2): 13-24.

“The Dene Declaration.” 1976. Canadian Association in Support of the Native Peoples Bulletin 17 (1): 3.

Vipond, Robert C. 1989. "1787 and 1867: The Federal Principle and Canadian Confederation Reconsidered." Canadian Journal of Political Science 22 (1): 3-25.

Walters, Mark D. 2006. “The Morality of Aboriginal Law.” Queen’s Law Journal 31 (2): 470-520.

Zlotkin, Norman K. 1984. "The 1983 and 1984 Constitutional Conferences: Only the Beginning." Canadian Native Law Reporter 3: 3-29. 
Chapter 4: Outlining the Duty to Consult \& Accommodate-Haida Nation and Taku River

The current legal framework for the duty of settler governments to consult with Indigenous peoples is founded in two landmark decisions of the Supreme Court of Canada, both decided in 2004: Haida Nation v. B.C. (Minister of Forests), and Taku River Tlingit First Nation v. B.C. The duty to consult entered the judicial lexicon with the 1997 Delgamuukw v. B.C. decision, but the Haida and Taku River cases expanded the duty's application, and reinforced the importance of consultation as a tool of reconciling Indigenous sovereignty and Crown sovereignty.

In answering the central research question of this dissertation regarding judicial discourse on the duty to consult and accommodate, we must first understand how the judiciary has framed the duty. It is this legal frame that bounds the consultation policies of non-Indigenous governments, including the Province of Ontario. This chapter will review the facts of the cases themselves, and discuss what they imply for the implementation of consultation and accommodation policy. While Haida and Taku River represented an important shift in judicial discourse on Crown sovereignty, the scarcity of guidelines surrounding the duty to consult and accommodate remains a threat to the reconciliation of parallel sovereignties envisioned by the Court. In closing, we will examine some of the challenges of consultation and key factors policymakers should consider during the implementation of the duty.

\section{A. The Cases \\ i. $\quad$ Haida Nation v. B.C. (Minister of Forests)}

At issue in the Haida case was the ability of the government of British Columbia to grant and transfer "tree farm licences", or TFLs, to firms logging on traditional territories over the 
objection of local First Nations. In 1999 the BC government transferred TFL 39, which covered a large portion of the islands of Haida Gwaii, to Weyerhaeuser Inc. In January 2000, the Haida Nation launched a lawsuit over the transfer on the grounds that they held legal title to the land. The Court noted that this title was still the subject of an ongoing land claim process, and absent the conclusion of that process, the title of the Haida remained unrecognized by the $\mathrm{BC}$ government. The Haida argued that they had continuously inhabited Haida Gwaii (formerly the Queen Charlotte Islands) since before the assertion of British sovereignty in 1846 and before first European contact in 1774. They also argued that the use of red cedar trees was integral to their culture, being used for the construction of houses, canoes, totem poles, and other ceremonial and artistic objects. (Tzimas 2005, 465) The Haida argued that they should have been consulted and their concerns accommodated, even without government recognition of their title. As noted by Chief Justice Beverly McLachlin:

The stakes are huge. The Haida argue that absent consultation and accommodation, they will win their title but find themselves deprived of forests that are vital to their economy and culture. Forests take generations to mature, they point out, and old-growth-forests can never be replaced. The Haida's claim to title to Haida Gwaii is strong, [...] [b]ut it is also complex and will take many years to prove. In the meantime, the Haida argue, their heritage will be irretrievably despoiled.(Haida Nation v. British Columbia (Minister of Forests) 2004b, para. 7)

The lower court rejected the idea that the Crown should have to accommodate an unproven right, and held that the Crown was only under a "moral duty to consult", not a legal one. The BC Court of Appeal overturned this decision, and held that both the Crown and Weyerhaeuser Inc. owed the Haida a duty to consult and to accommodate their interests. (Tzimas 2005, 466-67) Finally, in a unanimous decision, the Supreme Court held that the Crown (and specifically the Province of British Columbia) owed a duty to consult and accommodate the Haida Nation - a duty which the Province had not fulfilled. Further, the Court held that the duty 
could not be discharged by delegation to third parties, meaning that Weyerhaeuser owed no duty to consult. (Haida Nation v. British Columbia (Minister of Forests) 2004b, paras. 10, 76, 79)

Prior to the Haida case, legal guidance on the duty to consult emanated from the 1997 Delgamuukw v. $B C$ decision. In that judgment, the Court held that as part of the Crown's justification for infringing upon Aboriginal title, it always owes a duty of consultation. The Court also helped to define the scope of the duty:

The nature and scope of the duty of consultation will vary with the circumstances. In occasional cases, when the breach is less serious or relatively minor, it will be no more than a duty to discuss important decisions [...] Of course, even in these rare cases where the minimum acceptable standard is consultation, this consultation must be in good faith and with the intention of substantially addressing the concerns of the Aboriginal peoples whose lands are at issue. In most cases, it will be significantly deeper than mere consultation. Some cases may even require the full consent of an Aboriginal nation, particularly when provinces enact hunting and fishing regulations in relation to Aboriginal lands. (Delgamuukw v. British Columbia 1997a, 1113 emphasis added; see also Lawrence and Macklem 2000, 257)

This early conception of the duty to consult was grounded in the "Sparrow test", so named for the 1990 R. v. Sparrow decision. The Sparrow test requires that Crown infringement of Aboriginal rights be measured against whether those rights were deemed to "exist" prior to 1982, and as such be affirmed as "existing Aboriginal and treaty rights" under Section 35(1) of the Constitution Act, 1982. (Lawrence and Macklem 2000, 255-56; Sterling and Landmann 2009a, 1) As alluded to above, this meant that the Crown had to formally recognize an Aboriginal right before this recognition required it to curb its own practices. The Haida pointed out this paradox, and Chief Justice McLachlin agreed, writing:

The Crown, acting honourably, cannot cavalierly run roughshod over Aboriginal interests where claims affecting these interests are being seriously pursued in the process of treaty negotiation and proof. It must respect these potential, but yet unproven, interests. The Crown is not rendered impotent. It may continue to manage the resource in question pending claims resolution. But, depending on the 
circumstances, $[\ldots]$ the honour of the Crown may require it to consult with and reasonably accommodate Aboriginal interests pending resolution of the claim. To unilaterally exploit a claimed resource during the process of proving and resolving the Aboriginal claim to that resource, may be to deprive the Aboriginal claimants of some or all of the benefit of the resource. That is not honourable. (Haida Nation v. British Columbia (Minister of Forests) 2004b, para. 27)

The Haida case thus departed from precedent by requiring that the Crown consult with and accommodate Indigenous nations even in the absence of formal rights recognition. The McLachlin Court based this duty in the honour of the Crown, and it is worth taking a moment to explore precisely what this means.

In English common law, the honour of the Crown is based in the infallibility of the monarch. As E. Ria Tzimas explains, "The animating idea behind this principle was that the Crown, as head of the state of England, was a benevolent leader who would not knowingly aggrieve a subject nor fail to observe a promise.” (Tzimas 2005, 468) Indeed, Justice McLachlin cites a similar passage from the $1996 R$. v. Badger decision, stating "It is always assumed that the Crown intends to fulfill its promises." (quoting Badger at para. 41, Haida Nation v. British Columbia (Minister of Forests) 2004, para. 20) This is an important precept for all Canadians, as it speaks to the basic trust relationship between citizens and their government. But it has particular application in an Indigenous context.

Both Slattery and Tzimas offer a number of theories for how the honour of the Crown came to apply to Indigenous rights. One theory holds that when King George III extended Crown protection to Indigenous peoples in the Royal Proclamation of 1763, the Crown voluntarily assumed a duty of honourable dealing alongside its assertion of sovereignty. Another theory holds that the Royal Proclamation merely formalized an existing set of relationships between Indigenous nations and the Crown, in which a duty of honourable dealing was already established. Still another theory holds that the honour of the Crown is an interpretive tool used to 
determine legal responsibilities under treaty, and later under section 35(1) of the Constitution

Act, 1982. (Slattery 2005a, 443-44; Tzimas 2005, 468-69)

For its part the Supreme Court asserted in Haida that the honour of the Crown covers all dealings with Indigenous peoples, and provided the logical link to the duty to consult and accommodate:

The historical roots of the principle of the honour of the Crown suggest that it must be understood generously in order to reflect the underlying realities from which it stems. In all its dealings with Aboriginal peoples, from the assertion of sovereignty to the resolution of claims and the implementation of treaties, the Crown must act honourably. [...]

Put simply, Canada's Aboriginal peoples were here when Europeans came, and were never conquered. Many bands reconciled their claims with the sovereignty of the Crown through negotiated treaties. Others, notably in British Columbia, have yet to do so. The potential rights embedded in these claims are protected by s. 35 of the Constitution Act, 1982. The honour of the Crown requires that these rights be determined, recognized and respected. This, in turn, requires the Crown, acting honourably, to participate in processes of negotiation. While this process continues, the honour of the Crown may require it to consult and, where indicated, accommodate Aboriginal interests. (Haida Nation v. British Columbia (Minister of Forests) 2004b, paras. 17, 25)

In another oft-quoted passage, Chief Justice McLachlin linked the honour of the Crown

and the duty to consult with the larger project of reconciliation. Reconciliation, the Chief Justice reminds us, is a dynamic and ongoing process (see Slattery 2005a, 440):

[T] he duty to consult is part of a process of fair dealing and reconciliation that begins with the assertion of sovereignty and continues beyond formal claims resolution. Reconciliation is not a final legal remedy in the usual sense. Rather, it is a process flowing from rights guaranteed by s. 35(1) of the Constitution Act, 1982. This process of reconciliation flows from the Crown's duty of honourable dealing toward Aboriginal peoples, which arises in turn from the Crown's assertion of sovereignty over an Aboriginal people and de facto control of land and resources that were formerly in the control of that people. (Haida Nation v. British Columbia (Minister of Forests) 2004b, para. 32)

This idea of "asserted sovereignty" and "de facto control" represented an important shift.

Prior to Haida, Indigenous sovereignty had been considered a distinct source of sovereignty 
alongside the Crown, but the basis of the Crown's authority had never been questioned. As argued in Haida (and restated, as we will see below, in Taku River) until Crown sovereignty and pre-existing Indigenous sovereignty are reconciled through a process of treaty negotiation, Crown sovereignty over Indigenous territories is a matter of factual practice rather than law. This does not mean that Crown governments are deprived of decisionmaking power, but the McLachlin Court considered this de facto power rather that de jure legal authority. (see Hoehn $2012,77)$ The process of consultation, then, is an attempt by the Crown "to make good its sovereign claims by treating with aboriginal peoples to obtain their consent." (Walters 2006b, 514; see also Hoehn 2012, 44-52; Haida Nation v. British Columbia (Minister of Forests) 2004b, para. 26)

In addition to its novel view of sovereignty, the judgment in Haida also provided further guidance on the scope of the duty to consult. As mentioned above, the Court determined that the Crown alone bears the duty to consult, though it may "delegate procedural aspects of consultation to industry proponents." (Haida Nation v. British Columbia (Minister of Forests) 2004b, para. 53) The Court held that third party proponents can still be held legally liable for negligence or breach of contract, but only the Crown can discharge the duty to consult. ${ }^{25}$ (Haida Nation v. British Columbia (Minister of Forests) 2004b, para. 56) The Province of British Columbia also argued before the Court that it bore no duty to consult until the Haida had formally proven their land claim. The Court disagreed, saying that the duty to consult and accommodate is grounded in the assertion of Crown sovereignty - an assertion which pre-dates

\footnotetext{
${ }^{25}$ Like private proponents, municipalities also do not bear an independent duty to consult. (Association of Municipalities of Ontario 2019 , 9) Although they have a vested interest in the effective management of CrownIndigenous consultation, municipal governments do not derive any exclusive jurisdiction from the Crown, but rather through delegated powers outlined in provincial legislation.
} 
Confederation and under which British Columbia assumed responsibility. As such, the Provincial Crown has always borne the duty to consult and accommodate. (Haida Nation v. British Columbia (Minister of Forests) 2004b, para. 59)

By describing the duty to consult and accommodate as a pre-emptive duty, the Supreme Court was trying to reduce reliance on court-ordered solutions, and to encourage negotiations that better reflected the nation-to-nation relationship. (Haida Nation v. British Columbia (Minister of Forests) 2004b, para. 51; see also Lawrence and Macklem 2000, 258) The Court highlighted the importance of good faith on both sides, but noted that so long as the Crown made "reasonable efforts" to consult and accommodate in the circumstances, it could discharge its duty. (Haida Nation v. British Columbia (Minister of Forests) 2004b, paras. 61-63) There remained, in the words of the Court "no duty to agree." (Haida Nation v. British Columbia (Minister of Forests) 2004b, para. 42) As we will examine below, by stopping short of full consent, the duty to consult remains a potential danger to Indigenous rights in the long term.

Nevertheless, the Haida case represented a significant advancement in Canadian jurisprudence on Indigenous rights. Both Brian Slattery and Felix Hoehn argue that the decision interpreted section 35 as generating a new constitutional order. By recognizing the pre-existence of Indigenous sovereignty and interpreting Crown sovereignty as "assumed" or "de facto" in the absence of a treaty, this implies continued Aboriginal jurisdiction over their territories. In this paradigm, Aboriginal rights with strong prima facie evidence are presumed to exist, independently of government recognition, and the Crown is mandated to negotiate compromise between existing Aboriginal rights and broader societal goals. Only through negotiation can the Crown reconcile these parallel sovereignties. (Slattery 2005a, 436-37, 442-43; Hoehn 2012, 3435) 


\section{ii. Taku River Tlingit First Nation v. B.C.}

In the companion case to the Haida decision, the Taku River decision similarly dealt with the duty to consult and accommodate Indigenous peoples on matters which might affect their Aboriginal rights, but while those rights are still unrecognized.

In 1994, a mining company, Redfern Resources Inc., sought permission from the BC government to reopen an old mine in the province's northwest, which formed part of the traditional territory of the Taku River Tlingit First Nation. As part of the approvals process under BC's Environmental Assessment Act, Redfern formed a project committee including representatives of the Taku River Tlingit. At issue was the construction of a $160 \mathrm{~km}$ access road to the mine. The Tlingit were concerned that the road would disrupt local wildlife critical to their traditional land use, including hunting and fishing. They argued that there was not sufficient baseline data to monitor any potential changes, and that the access road might become a locus for further development, thereby worsening its environmental impact. The Tlingit also expressed interest in revenue sharing and jurisdiction over project permits. They were told that many of these concerns were issues of treaty negotiation, and beyond the scope of the environmental assessment process. Despite this, the Province approved funding for a wildlife monitoring program in the area, facilitated contact between the Taku River Tlingit and relevant provincial agencies, and hired a consultant in 1997 to study traditional land uses and try to resolve some of the issues raised by the Tlingit. In 1998 the project was approved, with the caveat that Redfern collect baseline data for wildlife, and adjust the route of the access road with continued participation from the Tlingit. However, this approval was granted over the continued objection 
of the Tlingit, who filed suit against the Province. (Taku River Tlingit First Nation v. British Columbia (Project Assessment Director) 2004a, paras. 1-22)

The Supreme Court found that, unlike the Haida, the Taku River Tlingit were active participants in the consultation process over a period of three and a half years. Further, the Court found that the environmental assessment process was sufficient to discharge the Province's duty to consult in this case, and that no special consultation measures were required. As Chief Justice McLachlin wrote:

Where consultation is meaningful, there is no ultimate duty to reach agreement. Rather, accommodation requires that Aboriginal concerns be balanced reasonably with the impact of the particular decision on those concerns and with competing societal concerns. Compromise is inherent to the reconciliation process. In this case, the Province accommodated TRTFN [Taku River Tlingit First Nation] concerns by adapting the environmental assessment process and the requirements made of Redfern in order to gain project approval. I find, therefore, that the Province met the requirements of its duty toward the TRTFN. (Taku River Tlingit First Nation v. British Columbia (Project Assessment Director) 2004a, para. 2)

Despite different outcomes for the First Nations involved, the Taku River decision emulated Haida in some important respects. Among these was the role the Court envisioned for the Provincial Crown. As in Haida, the BC Crown argued that it held no duty to consult until the Tlingit proved their rights through the treaty negotiation process. Until then, the Province argued, it owed only a "duty of fair dealing". The Court pointed out that the Tlingit had been in treaty negotiations with the BC Treaty Commissioner since 1993, and had filed for a land claim with the federal government as early as 1983 . Given this, the Province had clear knowledge of the Tlingit's claim to land title. (Taku River Tlingit First Nation v. British Columbia (Project Assessment Director) 2004a, para. 26) In its decision, the Court reiterated its view of Section 35, articulated in Haida, that it provides the foundation of a reconciled relationship with Indigenous peoples stemming from the honour of the Crown: 
The Province's submissions present an impoverished vision of the honour of the Crown and all that it implies. As discussed in the companion case of Haida, [...] the principle of the honour of the Crown grounds the Crown's duty to consult and if indicated accommodate Aboriginal peoples, even prior to proof of asserted Aboriginal rights and title. The duty of honour derives from the Crown's assertion of sovereignty in the face of prior Aboriginal occupation. It has been enshrined in s. 35(1) of the Constitution Act, 1982, which recognizes and affirms existing Aboriginal rights and titles. Section 35(1) has, as one of its purposes, negotiation of just settlement of Aboriginal claims. In all its dealings with Aboriginal peoples, the Crown must act honourably, in accordance with its historical and future relationship with the Aboriginal peoples in question. The Crown's honour cannot be interpreted narrowly or technically, but must be given full effect in order to promote the process of reconciliation mandated by s. 35(1). (Taku River Tlingit First Nation v. British Columbia (Project Assessment Director) 2004a, para. 24 emphasis added)

Also like the Haida decision was the Court's vision of compromise between pre-existing Indigenous sovereignty and "assumed" or "de facto" Crown sovereignty on untreatied lands:

The purpose of s. 35(1) of the Constitution Act, 1982 is to facilitate the ultimate reconciliation of prior Aboriginal occupation with de facto Crown sovereignty. Pending settlement, the Crown is bound by its honour to balance societal and Aboriginal interests in making decisions that may affect Aboriginal claims. The Crown may be required to make decisions in the face of disagreement as to the adequacy of its response to Aboriginal concerns. Balance and compromise will then be necessary. (Taku River Tlingit First Nation v. British Columbia (Project Assessment Director) 2004a, para. 42)

Why, then, did the Court rule in favour of the Province after this admonishment? In its judgement, during the three and a half years the Taku River Tlingit took part in the environmental assessment process, they were kept informed of plans for development and land use. When the Tlingit raised broader concerns beyond the scope of the Environmental Assessment Act, they were put in contact with relevant decision makers in other government agencies. The timeline for approvals was extended to accommodate further study before the environmental assessment was brought to a close in 1998. (Taku River Tlingit First Nation v. British Columbia (Project Assessment Director) 2004a, paras. 33-38) As in Haida, the Court reinforced its standard of "reasonableness" in determining the adequacy of consultation and 
accommodation. This requires good faith efforts on both sides of the negotiating table, and imposes no duty to agree on the final outcome. (Haida Nation v. British Columbia (Minister of Forests) 2004b, paras. 62-63; see also Lawrence and Macklem 2000, 277; Newman 2014a, 95)

What the Haida and Taku River decisions did do was ground the duty to consult and accommodate firmly in the honour of the Crown, which has broader application than a set of Aboriginal rights recognized by non-Indigenous governments, and speaks to the Court's vision of Section 35 as a tool to reconcile pre-existing Indigenous sovereignty with assumed Crown sovereignty. But questions remained about which negotiating parties could discharge the duty on behalf of the Crown and when, in the absence of formal recognition, the duty itself was triggered.

\section{B. Who Consults, and When?}

The Supreme Court outlined two main criteria in Haida which would trigger the duty to consult and accommodate: (1) the Crown has prima facie knowledge of the existence of Aboriginal rights or title, and (2) it contemplates action which might adversely affect that right. (Haida Nation v. British Columbia (Minister of Forests) 2004b, para. 35; see also Lawrence and Macklem 2000, 267; Slattery 2005a, 438-39) Further, the Court, ruled: "Difficulties associated with the absence of proof and definition of claims are addressed by assigning appropriate content to the duty, not by denying the existence of a duty." (Haida Nation v. British Columbia (Minister of Forests) 2004b, para. 37) The "appropriate content" of the duty to consult will vary with the circumstances, and ranges from a simple notice of a public meeting when rights infringement is considered minor, to Indigenous participation in decisionmaking where rights infringement is considered highly significant, accompanied by evidence of how the Crown accommodated Indigenous concerns. (Haida Nation v. British Columbia (Minister of Forests) 2004b, paras. 43- 
44; Tzimas 2005, 474; Newman 2014a, 97) Dwight Newman remarks that it is not clear from the triggering test in Haida what kind of Aboriginal rights must be accommodated. For instance, do these include only traditional land uses, or contemporary governance issues such as economic self-determination? For example, should the Crown be required to accommodate the effects of resource extraction projects on Indigenous economies by offering revenue-sharing? Haida is not clear on these questions. (Newman 2014a, 107)

What is clear is that the duty to consult covers a range of Crown actions, extending not just to public works projects, but also to regulatory approvals of private sector projects. (Sterling and Landmann 2009a, 3) Senior public servants Lori Sterling and Peter Landmann stress the importance of cooperation on projects where multiple levels of government or multiple Crown agencies are involved in consultation. In such projects both Crown and Indigenous negotiators risk duplicating their efforts, which in turn strains their capacity to engage in consultation. All interested ministries, they argue, should be encouraged to act together as one Crown, which would allow a streamlined consultation process covering all aspects of a project. (Sterling and Landmann 2009a, 7-9; see also Lawrence and Macklem 2000, 260)

Who has the authority to speak on behalf of a united Crown? Building upon the Court's conception of de facto sovereignty, Kent McNeil argues that in the absence of a treaty, exclusive Aboriginal title is unbroken. This means that the Indigenous peoples alone hold the right to resources on untreatied lands, and not the Province. Further, McNeil argues, provincial laws of general application cannot extend beyond the division of powers in the British North America Act, meaning that the Provincial Crown has no authority to grant regulatory approvals on unceded Indigenous lands. (McNeil 2005, 450-53) Tzimas counters by pointing out that the Supreme Court did not question provincial jurisdiction in the Haida and Taku River decisions, 
choosing instead to endorse federal principles of negotiation between Indigenous and nonIndigenous polities. By undermining provincial jurisdiction, Tzimas argues, they would also be undermining confidence in the federal system, and by extension the constitution in which they based the duty to consult and accommodate. Rather, the Court chose to strengthen the existing constitutional paradigm by widening the constitutional circle, even as it suggested limits to the Crown's authority. (Tzimas 2005, 475, 480)

To what extent can the Crown delegate its duty to consult? As we have seen, the Haida decision allowed the Crown to delegate "procedural aspects" of the duty to consult to third parties. This usually implies private proponents, but can also include municipalities or government agencies. (Ariss, Fraser, and Somani 2017, 28) With this in mind, what "substantive" aspects of consultation remain the responsibility of the Crown? Sterling and Landmann argue that Crown duties of consultation are threefold: (1) the Crown must identify which Indigenous communities to consult and at which stage of the project, (2) advise the proponents of the appropriate extent of consultations, and (3) verify that that the consultation and accommodation that was implemented was sufficient to discharge the duty. (Sterling and Landmann 2009a, 10) The Crown may oversee the entirety of the consultation process, but as John Olynyk argues, private industry proponents may be better placed to carry out the consultations than Crown agencies. Many extractive industries have the capacity and expertise to deliver project-specific consultations, and have a better knowledge of the project itself to communicate to Indigenous communities. They are also better able to implement mitigation strategies directly, as part of project development. (Olynyk 2005, 4) But despite these advantages, Kaitlin Ritchie remarks, an over-reliance on private industry to deliver consultation and accommodation results in a disconnect between Indigenous peoples and the Crown. This 
might lead to a deterioration of the nation-to-nation relationship which the duty to consult and accommodate was intended to repair. (Ritchie 2013, 400, 414-16; see also Ariss, Fraser, and Somani 2017, 17, 41) Private industry may have its own reasons to conduct Indigenous consultations, irrespective of the Crown's duties. It may, for instance, be a matter or corporate policy, a method of risk management, or part of a contract agreement with the local Indigenous community. (Olynyk 2005, 6-7)

Given the Supreme Court's view of BC's environmental assessment process in the Taku River case, it is clear that the duty to consult and accommodate does not, by definition, require a separate process engaging Indigenous parties exclusively to discharge the duty. If the projected rights infringement is relatively minor, Indigenous representations can form part of a general public consultation. But where impacts are deemed to be more severe, a separate Indigenous process better reflects the nation-to-nation relationship at the heart of consultation. A separate Indigenous process may also be required where traditional territories overlap, and multiple Indigenous communities are affected by a project. (Newman 2014a, 93-94; see also Peach 2016, 107)

Projects involving multiple Indigenous organizations or multiple communities present an additional layer of complexity. The Crown may find itself in a position where it doesn't know with whom to consult, and different organizations may have distinct claims to Aboriginal rights and title. The general academic consensus is for the Crown to err on the side of inclusiveness. Indigenous communities may appoint consultation partners from tribal councils, umbrella groups, or provincial-territorial organizations (PTOs) to speak on their behalf, but it is the communities themselves which hold Aboriginal rights and title. (Sterling and Landmann 2009a, 4-5; Peach 2016, 99, 102; Land 2014, 6) In previous chapters, we have seen the position of the 
Royal Commission on Aboriginal Peoples, and authors such as Kiera Ladner who argue that Indigenous governance is most appropriately exercised at the nation level, and Band government is the creation of a colonial regime. But Crown representatives have tended to defer to elected community leaders over traditional leadership; and while nation-building efforts are still ongoing, that still encompasses a great many Band Councils.

Similarly, Kent McNeil remarks that the Court in Haida did not question whether the BC government owed a duty to consult the Haida Nation as a whole, which includes two separate Band Councils, whereas in Taku River the Court maintained that the duty to consult was owed to the Taku River Tlingit First Nation - a single Indian Act Band. McNeil remarks that this is appropriate, since it allows leeway for the Indigenous peoples concerned to represent their own collectivities. Indigenous people themselves are the experts on their legal orders and polities, and a legalistic definition of Indigenous rights-holders would be, by its nature, an imposition by a judiciary that is generally less familiar with Indigenous law. (McNeil 2016, 36, 46-47)

\section{Accommodation, Consent, and Reconciliation}

Beyond consultation itself, what constitutes appropriate accommodation? As we have seen, consultation itself does not require agreement. Aboriginal rights and title which the Crown has recognized through treaty negotiation gives rise to a "fiduciary duty" that is, the Crown is mandated to act in the best interests of Indigenous peoples on matters pertaining to those rights. But, the Supreme Court noted in Haida, this fiduciary duty "does not connote a universal trust relationship encompassing all aspects of the relationship between the Crown and Aboriginal peoples." (Haida Nation v. British Columbia (Minister of Forests) 2004b, para. 18) The duty to consult and accommodate applies much more generally, even when Aboriginal rights and title are not recognized. Therefore, it does not meet the Supreme Court's threshold for a fiduciary 
duty. The outcome of consultation does not require that the Crown act in the best interest of Indigenous peoples, so long as it has followed a "meaningful process of consultation". (Haida Nation v. British Columbia (Minister of Forests) 2004b, para. 42) This has implications for the cumulative effects of consultation, which this chapter will return to presently. However, this lower legal standard does not preclude the consent of Indigenous peoples with land claims still pending. Paraphrasing Delgamuukw, the Court noted in Haida that in the event of a serious potential breach of Aboriginal rights, "full consent of the Aboriginal nations" would be necessary, and "would apply as much to unresolved claims as to intrusions on settled claims." (Haida Nation v. British Columbia (Minister of Forests) 2004b, para. 24; see also Joffe 2015, 5) Still, this leaves the seriousness of rights infringement largely up to the Crown's own estimation, and not to Indigenous peoples themselves.

In order to protect their land rights, Indigenous peoples can apply for a court-ordered injunction. This tactic was used, for example, by the James Bay Cree to temporarily halt the construction of a hydroelectric dam while they negotiated the first modern land claim, the James Bay and Northern Quebec Agreement, in 1975. But the Supreme Court cautioned that injunctions are at best a temporary solution. Because injunctions are an all-or-nothing solution to development, if it is overturned on appeal, there will be no balancing of Indigenous rights with other societal goals when development resumes. The duty to consult and accommodate, wrote the Court, is built around negotiation and compromise, and takes Indigenous concerns into account while at the same time reducing recourse to litigation. (Haida Nation v. British Columbia (Minister of Forests) 2004b, paras. 13-14; see also Lawrence and Macklem 2000, 271)

When protecting Indigenous rights from development, time is also an important factor. In its rationale for the duty to consult and accommodate, the Court argued that limiting the duty to 
recognized rights and title would allow continued development pending claims resolution, and deprive Indigenous peoples, in whole or in part, of the benefit of their underlying title. Given this, the Court also imposed a standard of "responsiveness" in the Taku River decision alongside its call for "reasonable" consultation efforts. Thought the Court states that responsiveness to Aboriginal concerns is "a key requirement of both consultation and accommodation", (Taku River Tlingit First Nation v. British Columbia (Project Assessment Director) 2004a, para. 25) the judgment offers no further insight as to how governments might measure responsiveness.

In general, the duty to consult and accommodate as conceived by the Supreme Court in Haida and Taku River is essentially a doctrine of procedural fairness. (see Lawrence and Macklem 2000, 258, 267) But the doctrine can affect reconciliation quite differently depending on how it is implemented by government. In Veronica Potes's analysis of the duty to accommodate, she distinguishes between what she calls a "procedural approach" to accommodation and a "purposive approach". The former, Potes argues, helps define the Crown's administrative duties, and does not question the Crown's place as the source of decisionmaking authority in balancing settler and Indigenous interests. The latter, by contrast, eschews unilateral decisionmaking, places greater focus on outcomes, and links the duty to consult and accommodate with the exercise of section 35 rights and the broader societal project of reconciliation. (Potes 2006, 33-34, 37) So conceived, the procedural justice of the duty to consult can be likened to a treaty relationship, that is, a dynamic process which both recognizes and accommodates pre-exiting Indigenous sovereignty with the interests of settler society. (Sossin 2010a, 104, 107; Ritchie 2013, 398)

As with the duty to consult, the duty to accommodate falls on a spectrum, depending on the strength of the prima facie Indigenous claim, and the extent of the proposed infringement. 
(Potes 2006, 31-32; Ariss, Fraser, and Somani 2017, 20) The accommodation of Indigenous concerns ought to provide some proof that consultations were conducted in good faith. (Ariss, Fraser, and Somani 2017, 8) However, the Court provided little guidance for accommodation beyond avoiding irreparable damage to Indigenous rights and title. Without this guidance, it is conceivable that non-Indigenous governments could adopt Potes's "procedural approach", and simply go ahead with projects after a brief exercise in consultation. But this would upset the animating purpose of consultation. An unwillingness compromise on either side would simply be preventing others from exercising their legal rights,(Newman 2014b, 15) and as such the duty to consult and accommodate could not be discharged. In practice, there have been many examples of governments accommodating Indigenous rights, ranging from project modifications to habitat restoration, and impact benefit agreements to wholesale cancellations of projects. (Sterling and Landmann 2009a, 13-14; Newman 2014a, 104-5)

While the Supreme Court held that only the Crown, and not third party proponents, could discharge the duty to consult, no statement was offered as to private industry's duty to accommodate. It was not clear what, if any, accommodation is owed by law to Indigenous communities. As with the duty to consult, some private proponents addressed accommodations on their own, for example through commitment to environmental mitigation measures, or employment opportunities and job training. But the question of private accommodation remained unsettled in the wake of Haida and Taku River. (Olynyk 2005, 5)

The major hurdles faced by Indigenous communities with the duty to consult and accommodate relate less to who owes a duty to whom, but rather in the asymmetries of power embedded in the consultation process, both with respect to government and with respect to other 
Indigenous communities. ${ }^{26}$ Different Indigenous communities can bring differing financial and human resources to bear in their consultations with the Crown. Those communities with less consultation capacity will hold less bargaining power against their Crown counterparts - even more so if the community sits at multiple negotiating tables and has to choose which negotiations to prioritize. (Lawrence and Macklem 2000, 273-74; Tzimas 2005, 482-83; Newman 2014a, 113; 2014b, 16) Consultation can also divert time, effort, and resources away from other community projects. (Ritchie 2013, 428-29)

Finally, there is the risk posed by the cumulative effects of consultation. Potes contends that the strong development bias of consultations may mean that a project is modified to accommodate Indigenous concerns, but never questions the basic good of development in the first place. Furthermore, settler governments and courts have frequently been unwilling to address past Crown conduct in their duty of honourable dealing. (Promislow 2013a, 67) Taken together, the duty to consult and accommodate may, in reality, be trying to reconcile two fundamentally opposing visions of land use and resource management. (Potes 2006, 39-40) When accommodation is viewed in this light, Mark Walters asks whether "the Court [is] more interested in reconciling the sovereignty of the Crown with the honour of the Crown than in reconciling the sovereignty of the Crown with the sovereignty of aboriginal peoples." (Walters

\footnotetext{
${ }^{26}$ Some authors point to these differential power relations as an outgrowth of broadly "Indigenous" and broadly "Western" governance traditions. Mark Walters, for instance, identifies certain key attributes common to Indigenous legal orders, including the "absence of coercive institutions" (Walters 2006b, 482 see Chapter 2, Section E for greater discussion). In Western political history, writ large, force, coercion, and manipulation are principal ways of achieving political dominance; (McLean and McMillan 2009, 427) and these have been institutionalized through colonial policy. Levelling the playing field between Indigenous and settler governments by providing direct or indirect support for Indigenous negotiators and consultation staff would help organize consultations on the basis of legal legitimacy rather than financial resources. Chapter 6 of this dissertation will delve further into how such support mechanisms might operate.
} 
2006b, 518) Even if a project is modified, it is likely to get built, and each time there is less land available upon which Indigenous peoples can exercise their rights. (Ritchie 2013, 400, 432)

Similarly, Kim Stanton argues that the Haida and Taku River cases presented a shift in judicial discourse insofar as they questioned the assertion of Crown sovereignty in the absence of negotiation with Indigenous peoples. (Stanton 2017b, 29-30) However, if negotiations fail, the Crown may proceed in exercising its authority so long as their efforts are deemed "reasonable" by settler courts. The lack of an Indigenous veto over projects backed by the Crown effectively skews consultation and accommodation in the Crown's favour. (Ariss, Fraser, and Somani 2017, 11) This means that in practice, the Court's conceptions of "assumed" or "de facto" Crown sovereignty can be legally sufficient to infringe upon Indigenous rights and title.

So what can be done to level the playing field? Ritchie suggests that beyond making funding opportunities available to Indigenous communities, governments should be obligated to provide consultation funding to communities as a way of addressing capacity imbalances. (see also Ariss, Fraser, and Somani 2017, 19) Revenue-sharing agreements are one method of addressing these capacity issues, but this may be undesirable compared to direct government transfers, since it risks incentivizing resource extraction on traditional territories so Indigenous governments can meet their basic fiscal needs. (Scott and Boisselle 2019,36) Ritchie further argues that there should be less reliance on delegation to third parties, because this division makes it more difficult to negotiate as one Crown, and because greater Crown involvement better emulates the nation-to-nation relationship. With greater involvement in consultation, the Crown negotiators can better be made aware of the cumulative effects of consultation on the development of traditional territories, and this consideration can be taken into account during the accommodation process. (Ritchie 2013, 435-38) Crown representatives must be made aware that 
treaties embody a relationship based on shared jurisdiction and shared territory, and the reconciliation of settler and Indigenous interests requires "mandating negotiations to delineate how this sharing will occur." (Scott and Boisselle 2019, 28)

\section{Conclusion}

In brief, we can see that while the Supreme Court envisioned the duty to consult and accommodate as a tool of reconciliation, the vagueness of the doctrine in certain areas, particularly with respect to accommodation, has led to major challenges for some Indigenous communities. Both governments and private industry would do well to consult and accommodate in good faith, both because negotiated solutions reduce recourse to litigation, and because negotiating in good faith is a necessary component of the treaty relationship, foundational to both Canadian federalism and Canada's societal project of reconciliation. It is worth remembering that Aboriginal rights and title are constitutional rights, enshrined under Section 35, and consultation between the Crown and Indigenous peoples is as fundamental to the federation as consultations between orders of government.

The following chapter will examine how key, post-Haida decisions of the Supreme Court helped apply the duty to consult and accommodate to treaty rights, distinguished between "contractual" and "covenantal" readings of treaty law, and further defined the role of provincial governments with respect to Indigenous peoples. This brief overview of landmark jurisprudence will then be complete, and can be compared to Ontario's implementation of consultation policy in the penultimate chapter. 


\section{$\underline{\text { References }}$}

Ariss, Rachel, Clara MacCallum Fraser, and Diba Nazneen Somani. 2017. "Crown Policies on the Duty to Consult and Accommodate: Towards Reconciliation?” McGill Journal of Sustainable Development Law 14 (1): 3-55.

Association of Municipalities of Ontario. 2019. "Municipal Governments and the Crown's 'Duty to Consult." https://www.amo.on.ca/AMO-PDFs/Reports/2019/AMO-Discussion-Paper-Municipal-Governments-and-the.aspx.

Delgamuukw v. British Columbia. 19973 SCR 1010. Supreme Court of Canada.

Haida Nation v. British Columbia (Minister of Forests). 2004 [2004] 3 SCR 511. Supreme Court of Canada.

Hoehn, Felix. 2012. Reconciling Sovereignties: Aboriginal Nations and Canada. Saskatoon: Native Law Centre, University of Saskatchewan.

Joffe, Paul. 2015. “'Veto' and 'Consent' - Significant Differences.” Assembly of First Nations.

afn.ca/uploads/files/2015_usb_documents/veto-and-consent-significant-differences-joffe-final-july-31-15.pdf.

Land, Lorraine. 2014. “Creating the Perfect Storm for Conflicts Over Aboriginal Rights: Critical New Devlopments in the Law of Aboriginal Consultation." Olthuis Kleer Townshend LLP. http://www.oktlaw.com/wpcontent/uploads/2016/10/lylPerfectStorm.pdf.

Lawrence, Sonia, and Patrick Macklem. 2000. "From Consultation to Reconciliation: Aboriginal Rights and the Crown's Duty to Consult." Canadian Bar Review 79: 252-79.

McLean, Iain, and Alistair McMillan, eds. 2009. "Power." In The Concise Oxford Dictionary of Politics, 3rd ed., 425-28. Oxford University Press.

McNeil, Kent. 2005. “Aboriginal Rights, Resource Development, and the Source of the Provincial Duty to Consult in Haida Nation and Taku River.” Supreme Court Law Review 29 (1): 447-60.

- 2016. "Aboriginal Title and Indigenous Governance: Identifying the Holders of Rights and Authority," Indian and Aboriginal Law Commons, . http://digitalcommons.osgoode.yorku.ca/all_papers/264.

Newman, Dwight. 2014a. Revisiting the Duty to Consult Aboriginal Peoples. Saskatoon: Purich Publishing Ltd. 2014b. "The Rule and the Role of Law: The Duty to Consult, Aboriginal Communities, and the Canadian Natural Resource Sector." 4. Aboriginal Canada and the Natural Resource Economy Series. Ottawa: MacdonaldLaurier Institute.

Olynyk, John. 2005. "The Haida Nation and Taku River Tlingit Decisions: Clarifying Roles and Responsibilities for Aboriginal Consultation and Accommodation.” Lawson Lundell LLP.

Peach, Ian. 2016. "Who Speaks for Whom? Implementing the Crown's Duty to Consult in the Case of Divided Aboriginal Political Structures.” Canadian Public Administration 59 (1): 95-112.

Potes, Veronica. 2006. “The Duty to Accommodate Aboriginal Peoples Rights: Substantive Consultation?” Journal of Environmental Law and Practice 17 (1): 27-45.

Promislow, Janna. 2013. "Irreconcilable? The Duty to Consult and Administrative Decision Makers." Constitutional Forum 22 (1): 63-78. 
Ritchie, Kaitlin. 2013. "Issues Associated with the Implementation of the Duty to Consult and Accommodate Aboriginal Peoples: Threatening the Goals of Reconciliation and Meaningful Consultation." University of British Columbia Law Review 46 (2): 397-438.

Scott, Dayna Nadine, and Andree Boisselle. 2019. "If There Can Only Be 'One Law', It Must Be Treaty Law. Learning from Kanawayandan D'aaki,” Articles \& Book Chapters, .

https://digitalcommons.osgoode.yorku.ca/scholarly_works/2745.

Slattery, Brian. 2005. "Aboriginal Rights and the Honour of the Crown.” Supreme Court Law Review 29 (2d): $433-$ 45.

Sossin, Lorne. 2010. "The Duty to Consult and Accommodate: Procedural Justice as Aboriginal Rights." Canadian Journal of Administrative Law \& Practice 23: 93-113.

Stanton, Kim. 2017. "Reconciling Reconciliation: Differing Conceptions of the Supreme Court of Canada and the Canadian Truth and Reconciliation Commission." Journal of Law and Social Policy 26 (2): 21-42.

Sterling, Lori, and Peter Landmann. 2009. "The Duty to Consult Aboriginal Peoples - Government Approaches to Unresolved Issues.” Canadian Bar Association. www.cba.org/cba/cle/PDF/Constit09_Sterling_paper.pdf.

Taku River Tlingit First Nation v. British Columbia (Project Assessment Director). 2004 [2004] 3 SCR 550. Supreme Court of Canada.

Tzimas, E. Ria. 2005. "Haida Nation and Taku River: A Commentary on Aboriginal Consultation and Reconciliation.” Supreme Court Law Review 29 (1): 461-84.

Walters, Mark D. 2006. “The Morality of Aboriginal Law.” Queen's Law Journal 31 (2): 470-520. 


\section{Chapter 5: Applying the Duty to Consult \& Accommodate to Provincial Policy Roles}

In the years which followed the seminal Haida Nation and Taku River decisions, successive decisions by the Supreme Court of Canada gave greater shape to the application of the honour of the Crown and the duty to consult and accommodate. Key among these for provincial governments were Mikisew Cree First Nation v. Canada (Minister of Canadian Heritage) (2005), Beckman v. Little Salmon/Carmacks First Nation (2010), and the companion cases of Tsilhqot'in Nation v. British Columbia and Grassy Narrows First Nation v. Ontario (Natural Resources) (2014). Each of the decisions explored in this chapter increased the importance of the provincial role in Indigenous policy, and explicitly crafted new constitutional law which opened (or rather, renewed) policy space for Indigenous governments. These cases did so by applying the honour of the Crown and the attendant duty to consult and accommodate to all Crown-Indigenous relations, whether the Crown-in-Right is federal or provincial. They also cover the gamut of treaty relationships, whether the relevant treaties are historic or modern or in the case of the Tsilhqot'in decision, whether Indigenous lands remain unceded.

Taken together, this body of law serves as an endorsement of ongoing negotiation and cooperation between Indigenous and settler governments. The cooperative, less siloed vision of Canadian federalism described in these Supreme Court decisions provides the substance of Judicial Treaty Federalism, and provides a legal framework for policy analysis. The clarification of provincial responsibilities in the Crown-Indigenous relationship completes the legal foundation from which this dissertation analyzes Ontario's First Nation consultation policies in the next chapter. 


\section{A. Mikisew Cree (2005)}

Mikisew Cree First Nation v. Canada (Minister of Canadian Heritage) was the first Supreme Court case, post-Haida, to apply the duty to consult and accommodate to a CrownIndigenous treaty. Central to the case was the language of Treaty 8 , signed in 1899 , which encompasses an area spanning some 840,000 square kilometres across northern Alberta, northeastern British Columbia, northwestern Saskatchewan, and the southeastern Northwest Territories. The so-called "taking up" clause of Treaty 8 is worded as follows:

And her Majesty the Queen HEREBY AGREES with the said Indians that they shall have the right to pursue their usual vocations of hunting, trapping, and fishing throughout the tract surrendered as heretofore described, subject to such regulations as may from time to time be made by the Government of the country, acting under the authority of Her Majesty, and saving and excepting such tracts as may be required or taken up from time to time for settlement, mining, lumbering, trading or other purposes. (As cited in Mikisew Cree First Nation v. Canada (Minister of Canadian Heritage) 2005a, para. 2 emphasis added by Justice Binnie)

In 1922 some 5 percent of Treaty 8 lands were set aside for the creation of Wood Buffalo National Park. Within the park lies the Peace Point Reserve belonging to the Mikisew Cree First Nation, descendants of the Crees of Fort Chipewyan who were signatories to Treaty 8 in 1899. In January 2000, Parks Canada began an environmental assessment for a proposed 118-kilometre winter road, which would connect the town of Fort Smith, Northwest Territories to the Alberta highway system. The winter road had the support of a number of Indigenous communities near Fort Smith, including the Salt River First Nation, the Little Red River Cree First Nation, and the Fort Smith Métis Council. However, the proposed road was also slated to cut through the Peace Point Reserve. The Mikisew Cree were provided standard information about the project distributed to the general public and given until August to issue comment. When the Mikisew issued a formal response in October, they were told that they had missed the window for public comment. 
The Mikisew contended that the road, as well as the 200-metre wide "no firearm corridor" surrounding the road allowance infringed upon their rights to hunt, fish, and trap, as recognized and affirmed by Treaty 8 . Furthermore, Chief and Council argued that a public open house was not the appropriate forum for consultation on Aboriginal and treaty rights. Following the pushback from the Mikisew Cree, the road was rerouted to skirt the boundary of the Peace Point Reserve. However, the Mikisew were also not notified of the realignment. More to the point, the realignment did nothing to address the disruption to traditional practices and further exacerbated the lack of consultation; and so the Mikisew Cree took the Ministry of Canadian Heritage, which oversees Parks Canada, to court. (Mikisew Cree First Nation v. Canada (Minister of Canadian Heritage) 2005a, paras. 5-15; Schwartz and Rettie 2006, 467)

Given the timing of the Mikisew case, initial appeals did not draw upon the duty to consult and accommodate, which had yet to be outlined in Haida Nation (2004). Instead, since the rights of the Mikisew to hunt, trap, and fish were recognized and affirmed under treaty, they fell under the test for "justifiable infringement" outlined in the $1990 R v$. Sparrow decision. At trial, Justice Hansen sided with the First Nation, finding that general public notice insufficiently addressed direct consultation with the Mikisew, and that the Minister had not adequately justified this infringement of treaty rights. That decision was then overturned by the Federal Court of Appeal. Drawing upon the above-quoted "taking up" clause of Treaty 8, the Court of Appeal found that the treaty expressly contemplated the development of ceded lands by the Crown. As such, the construction of the road was a proper exercise of the Crown's rights under treaty. (Mikisew Cree First Nation v. Canada (Minister of Canadian Heritage) 2005a, paras. 19-23; Schwartz and Rettie 2006, 468) The Mikisew then appealed this decision to the Supreme Court of Canada. 
In their arguments before the Supreme Court, Crown counsel tried to distinguish the case of the Mikisew Cree from the previous year's decisions in Haida Nation and Taku River. They argued that whatever duty to consult and accommodate was owed to the Mikisew was discharged at the time of treaty negotiations in 1899 , and that Treaty 8 represented a complete code of the legal relationship between the Crown and First Nation signatories. Since the "taking up" of lands was contemplated in the treaty, no further duty to consult existed for subsequent development decisions concerning lands ceded to the Crown. (Mikisew Cree First Nation v. Canada (Minister of Canadian Heritage) 2005a, paras. 36-37; Bankes 2005, 6)

Justice Binnie, writing for a unanimous Court, vehemently rejected this argument, writing:

There is in the Minister's argument a strong advocacy of unilateral Crown action (a sort of "this is surrendered land and we can do with it what we like" approach) which not only ignores the mutual promises of the treaty, both written and oral, but also is the antithesis of reconciliation and mutual respect. [...] The duty to consult is grounded in the honour of the Crown, and it is not necessary for present purposes to invoke fiduciary duties [under treaty]. The honour of the Crown is itself a fundamental concept governing treaty interpretation and application that [has] been the Crown's policy as far back as the Royal Proclamation of 1763 [...] The honour of the Crown exists as a source of obligation independently of treaties. (Mikisew Cree First Nation v. Canada (Minister of Canadian Heritage) 2005a, paras. 49-50)

Justice Binnie further noted the internal tension within the "taking up" clause of Treaty 8 , which affirms the continued right of First Nations to live of their traditional lands, while simultaneously foreshadowing the continued development of those same lands by an increasing non-Indigenous population. To try and ease this tension, he pointed to the underlying purpose of the treaty, which is to define a set of relations between First Nations and the Crown - relations which were not intended to be full and final. (see Morellato 2008, 36) Justice Binnie further posits that not every "taking up" of land will require a justified infringement test under Sparrow, 
but the Crown, as a party to the treaty, should always know its treaty obligations and is expected to manage land use changes honourably. (Mikisew Cree First Nation v. Canada (Minister of Canadian Heritage) 2005a, paras. 25-35; see also Bankes 2005, 4; Schwartz and Rettie 2006, 469)

Following Justice Binnie's logic that the honour of the Crown, and by extension the duty to consult and accommodate, exists independently of treaty obligations, then consultation will be triggered at a relatively low threshold - any time the Crown contemplates land use which may have an adverse impact on Aboriginal and treaty rights. (Bankes 2005, 5) This gives rise to both procedural and substantive obligations for the Crown. Justice Binnie posited that had the Mikisew failed to demonstrate that the winter road was a violation of the Crown's substantive (i.e. fiduciary) obligations under the treaty, the Crown would still have owed them procedural duties of consultation and accommodation as part of honourable dealing. (Mikisew Cree First Nation v. Canada (Minister of Canadian Heritage) 2005a, para. 57; Morellato 2008, 35)

Building upon the verdict in Haida Nation, the Supreme Court ruled that the Mikisew Cree were owed consultation and accommodation by the federal Crown in the early stages of the project. The Court qualified this by suggesting that the extent of consultation in this case likely fell on the lower end of the consultation spectrum, meriting direct engagement with the Mikisew and taking their input into account in the realignment of the road. The Court reiterated that the appropriateness of consultation and accommodation is contextual, based on the specificity of promises made by the Crown, and the seriousness of the impacts proposed. Consultation and accommodation, the Court repeated, might not result in agreement, but disagreement would not provide the Mikisew a veto over the project. (Mikisew Cree First Nation v. Canada (Minister of Canadian Heritage) 2005a, paras. 63-66; see also Schwartz and Rettie 2006, 469) The verdict, 
then, placed a heavy emphasis on process in producing satisfactory outcomes to CrownIndigenous negotiations.

This process orientation is made plain by Justice Binnie's opening statement that "The fundamental objective of the modern law of aboriginal and treaty rights is the reconciliation of aboriginal peoples and non-aboriginal peoples and their respective claims, interests, and ambitions." (Mikisew Cree First Nation v. Canada (Minister of Canadian Heritage) 2005a, para. 1) But can these respective interests be reconciled? As discussed in the last chapter, consultation can harbour a basic pro-development bias, which over time risks eroding the land base upon which Indigenous peoples can freely practice their Aboriginal and treaty rights. The court's treatment of the proposed road in Mikisew may go some way to controlling that bias.

In addition to the road and its adjacent "no firearm corridor" which would have reduced the territory upon which the Cree could hunt, fish, and trap by some 23 square kilometres, the road also brought risks of fragmenting wildlife habitat, disrupting the migration of wild game, and increasing access for poachers. Crown counsel countered these concerns by saying that harvesting rights would not be affected over Treaty 8 territory as a whole, and the Mikisew would have continued access to hunting near Jasper, Alberta, some 800 kilometres distant, or roughly equivalent to the distance between Toronto and Quebec City. Understandably, Justice Binnie roundly rejected this argument, and emphasized the continuity of a "meaningful right to hunt" in relation to the lands on which treaty First Nations traditionally hunted, fished, and trapped. (Mikisew Cree First Nation v. Canada (Minister of Canadian Heritage) 2005a, paras. 44-48) As the Justice explains:

[F]or aboriginal people, as for non-aboriginal people, location is important. Twenty-three square kilometres alone is serious if it includes the claimants' hunting ground or trapline. While the Mikisew may have rights under Treaty 8 to 
hunt, fish and trap throughout the Treaty 8 area, it makes no sense from a practical point of view to tell the Mikisew hunters and trappers that, while their own hunting territory and traplines would now be compromised, they are entitled to invade the traditional territories of other First Nations distant from their home turf. (Mikisew Cree First Nation v. Canada (Minister of Canadian Heritage) 2005a, para. 47)

By trying to strike a balance between the needs of communities benefitting from the proposed road and emphasizing the continuity of Aboriginal and treaty rights for First Nations the road encroached upon, the Court's verdict in Mikisew offers important guidance for the goals of consultation and accommodation in advancing judicial framings of reconciliation. The judgment confirmed that the duty to consult and accommodate exists independently and is not conditional on the wording of applicable treaties. (Bankes 2005, 4) Even so, by decoupling the procedural duty to consult from substantive treaty obligations, some critics of the Supreme Court have contended that the judgment skirts fundamental questions of compensation.

Schwartz and Rettie argue that the Mikisew decision centred upon the adequacy of consultation in the planning stage of the project, rather than whether the Crown could justify a substantial infringement of harvesting rights protected by Treaty 8 . By finding that consultation was inadequate, the Court was never forced to compare written and oral version of Treaty 8 , nor assess whether the Crown owed the Mikisew compensation for "taking up" land. (Schwartz and Rettie 2006, 472-75)

Other authors are more hopeful about the Court's emphasis on consultation in Mikisew. As Maria Morellato states: "If Haida and Mikisew are to be taken seriously, there must be a significant paradigm shift in the way Crown decisions affecting Aboriginal and treaty rights are made in the future. Put simply, these cases direct that treaty peoples and First Nations be incorporated into the decision-making process engaged in by Crown officials in all decisions which impact their rights." (Morellato 2008, 37) Mikisew also clarified new minimum standards 
for consultation and accommodation. These standards can be summarized as follows (see Morellato 2008, 38-39; Schwartz and Rettie 2006, 470; Bankes 2005, 6):

1) The Crown must provide notice of a proposed project directly to Indigenous communities affected by it.

2) The Crown must inform itself of the seriousness of impact of the proposed project, assess what treaty obligations it has to the Indigenous peoples in question, and whether the treaty provides a framework for land use management.

3) The Crown must communicate this information to affected Indigenous communities.

4) The Crown must, in good faith, solicit and listen to the concerns of affected Indigenous communities.

5) The Crown must attempt to minimize the impact of the proposed project on Aboriginal and treaty rights, and demonstrably integrate Indigenous concerns into the plan of action.

6) The Crown is precluded from acting unilaterally.

7) Administrative inconvenience does not excuse a lack of meaningful consultation.

8) The duty to consult and accommodate does not require agreement to be discharged, and so does not afford Indigenous communities a veto over the proposed project.

These principles were a significant development over those articulated in Haida, which, at the low end of the consultation spectrum, only required the Crown to provide notice, disclose information, and issue a response to the concerns raised. (Schwartz and Rettie 2006, 471) The standards articulated in Mikisew would go on to inform future cases on the implementation of treaty rights and are important pieces in the judicial discourse on the settler recognition of Indigenous sovereignty. 


\section{B. Little Salmon/Carmacks (2010)}

Treaty rights once again came to the fore in the Beckman v. Little Salmon/Carmacks First Nation case of 2010. As in Mikisew five years before, Little Salmon/Carmacks also tried to determine whether the Crown had met its duty to consult, and whether or not the duty to consult and accommodate existed beyond the text of the treaty. What distinguished Little Salmon/Carmacks from Mikisew was the application of these questions to a comprehensive modern treaty rather than a historic treaty, and as will be discussed below, this distinction produced a split within the Court.

In 1996 the Little Salmon/Carmacks First Nation finalized a 400-page modern treaty with the federal government and the territorial government of Yukon. The Little Salmon/Carmacks First Nation Final Agreement was one of 11 such treaties signed pursuant to the 1993 Yukon Umbrella Final Agreement. Within the treaty, however, were two seemingly conflicting clauses: an "entire agreement clause" intended to reaffirm the certainty of the relationship outlined in the treaty, and a "non derogation clause", which stated that nothing in the agreement would prevent Yukon First Nations from exercising "any existing or future constitutional rights for aboriginal people that may be applicable to them." (Tzimas 2011b, 507)

In 2001, a non-Indigenous Yukon resident named Larry Paulsen submitted an application to the territorial government for an agricultural land grant of 65 hectares with the intention of cultivating pastureland and raising livestock. By 2004, the application had reached the third of four levels of review - a meeting with the Land Application Review Committee. The Committee invited representatives of the Little Salmon/Carmacks First Nation to participate in the meeting. The First Nation opposed the application, noting that the proposed land grant crossed a trapline, and cited concerns over the impact on hunting as well as cultural sites nearby. The Committee 
noted the objections of the First Nation, recommending an archaeological survey to study the potential impact on cultural sites. Nevertheless, they approved Mr. Paulsen's application on the grounds that the 65-hectare land grant covered approximately one third of one percent of the whole trapline, which covered an area of 21,345 hectares. In the Committee's view, this did not present an adverse impact to the First Nation. The Committee failed to inform the First Nation of the approval, and upon discovery of the approval, the First Nation sought judicial review on the grounds that the territorial government had failed in its duty to consult. In the lower courts, the trial judge found that the duty to consult had not been satisfied, but this verdict was overturned by the Yukon Court of Appeal.

When Little Salmon/Carmacks was appealed to the Supreme Court, the Court authored two concurring judgments, the first by Justice Binnie, writing for the majority, the second written by Justice Deschamps with Justice LeBel concurring. Both judgments found that the territorial government had not breached its duty to consult, but on very different grounds. The majority concluded that the territorial government had adequately consulted with the First Nation, and the minority concluded that the territory had not breached its duty to consult because the duty did not apply in this case.

In essence, the two Justices diverged on where the reconciliation of Indigenous and Crown sovereignties should take place. Justice Binnie held, as he had in Mikisew, that the duty to consult and accommodate exists independently of treaties, stemming from the Crown's duty of honourable dealing. The view of the treaty relationship articulated by Justice Binnie held that treaties, whether modern or historic, are subject to an ongoing process of negotiation. While he remained deferential to the text of a modern treaty, his position left room for differences of interpretation, and the application of the so-called Nowegegick principle: that "treaties and 
statutes relating to Indians should be liberally construed and doubtful expressions resolved in favour of the Indians.” (R. v. Nowegegick 1983, para. 36 as quoted in Newman 2011, 479)

Justice Deschamps, for her part, held that modern treaties capture renewed CrownIndigenous relationships by virtue of the years of consultation and negotiation which went into drafting them. As such, the text of a modern treaty should be the primary source for solutions to an impasse. (Tzimas 2011b, 495, 525-26; see also Bankes 2010, 1) Both judgements merit a closer look.

In the majority opinion of the Little Salmon/Carmacks decision, Justice Binnie argues that even though historic and modern treaties differ greatly in their specificity, modern treaties still do not provide a complete code for a relationship which would, in isolation, discharge the duty to consult and accommodate. He writes:

Unlike their historical counterparts, the modern comprehensive treaty is the product of lengthy negotiations between well-resourced and sophisticated parties. $[\ldots]$

The reconciliation of Aboriginal and non-Aboriginal Canadians in a mutually respectful long-term relationship is the grand purpose of s. 35 of the Constitution Act, 1982. The modern treaties, including those at issue here, attempt to further the objective of reconciliation not only by addressing grievances over the land claims but by creating the legal basis to foster a positive long-term relationship between Aboriginal and non-Aboriginal communities. Thoughtful administration of the treaty will help manage, even if it fails to eliminate, some of the misunderstandings and grievances that have characterized the past. [...] [T] he treaty will not accomplish its purpose if it is interpreted by territorial officials in an ungenerous manner or as if it were an everyday commercial contract. (Beckman v. Little Salmon/Carmacks First Nation 2010, paras. 9-10)

Justice Binnie continued:

The eight pages of generalities in Treaty No. 8 in 1899 is not the equivalent of the 435 pages of the LSCFN Treaty almost a century later. The LSCFN Treaty provides a solid foundation for reconciliation, and the territorial government is quite correct that the LSCFN Treaty should not simply set the stage for further negotiations from ground zero. Nor is that the First Nation's position. [...] 
Reconciliation in the Yukon, as elsewhere, is not an accomplished fact. It is a work in progress. The "complete code" position advanced by the territorial government is, with respect, misconceived. (Beckman v. Little Salmon/Carmacks First Nation 2010, para. 52)

To underscore the point that modern treaties are not a complete code, Justice Binnie pointed to the fact that the Final Agreement had no provision authorizing grants of Crown land where treaty rights continued to exist. The territorial government pointed to provisions in the general law which provided for this, but Justice Binnie contended that this law exists outside the treaty, and that the territorial government could not, therefore, argue that the modern treaty was a complete code and simultaneously apply general laws for convenience. (Beckman v. Little Salmon/Carmacks First Nation 2010, para. 62)

The text of a modern treaty does give shape to the content of consultation and accommodation, and Justice Binnie held, as he had in Mikisew, that the duty to consult and accommodate is a distinct legal obligation. He writes:

When a modern treaty has been concluded, the first step is to look at its provisions to try to determine the parties' respective obligations, and whether there is some form of consultation provided for in the treaty itself. If a process of consultation has been established in the treaty, the scope of the duty to consult will be shaped by its provisions. [...]

The duty to consult is imposed as a matter of law, irrespective of the parties' "agreement". It does not "affect" the agreement itself. It is simply part of the essential legal framework within which the treaty is to be interpreted and performed. [...]

The purpose of consultation was not to reopen the LSCFN Treaty or to renegotiate the availability of the lands for an agricultural grant. Such availability was already established in the Treaty. Consultation was required to help manage the important ongoing relationship between the government and the Aboriginal community in a way that upheld the honour of the Crown. (Beckman v. Little Salmon/Carmacks First Nation 2010, para. 67,69,73)

While the duty to consult and accommodate exists independently of the modern treaty, the trilogy of Haida Nation, Taku River, and Mikisew made clear that the content of the duty may 
vary by circumstance, and thus the Crown may need other tools in practicing honourable dealing. As Justice Binnie described it, "the duty to consult is a valuable adjunct to the honour of the Crown, but it plays a supporting role.” (Beckman v. Little Salmon/Carmacks First Nation 2010, para. 44) The terms of a modern treaty may offer other administrative processes, such as cooperative management, that can give appropriate weight to the constitutional interests of Indigenous parties and uphold the honour of the Crown. (Beckman v. Little Salmon/Carmacks First Nation 2010, paras. 46-47, 71; see also Jai 2009, 64)

Bearing these principles in mind, the majority held that the Final Agreement was not an inherently anti-development document, and the Little Salmon/Carmacks First Nation had not proposed alternative options to the outright rejection of the Paulsen application. The Court concluded that the territorial government had adequately consulted with the Little Salmon/Carmacks First Nation, and there was no evidence that government decisionmakers had failed to give "full and fair consideration" to First Nation concerns. (Beckman v. Little Salmon/Carmacks First Nation 2010, paras. 81-86)

In her concurring opinion, Justice Deschamps reiterated that the Supreme Court's endorsement of a duty to consult and accommodate Aboriginal rights, even where those rights have not yet been recognized by the Crown, was based in the Court's "desire to encourage the Crown and Aboriginal peoples to negotiate treaties rather than resorting to litigation." (Beckman v. Little Salmon/Carmacks First Nation 2010, para. 93). She argued that the honour of the Crown encapsulates a more expansive reading of the Crown's duties to protect Aboriginal and treaty rights than previous jurisprudence on fiduciary duties which, she suggested, carried paternalistic overtones. (Beckman v. Little Salmon/Carmacks First Nation 2010, paras. 105, 108) Furthermore, Justice Deschamps posited, the honour of the Crown and attendant duties to consult 
and accommodate reassert Section 35 rights as a constitutional accord. (Beckman v. Little Salmon/Carmacks First Nation 2010, paras. 102-103; see also Newman 2011, 484-85) This logic includes treaties among the constitutional compacts of Canadian federalism, these being (1) the compact between individuals and the Crown regarding the protection of fundamental rights and freedoms, (2) the compact between Indigenous and non-Indigenous peoples regarding the protection of Aboriginal and treaty rights, and (3) the federal compact between the federal and provincial Crowns. (Beckman v. Little Salmon/Carmacks First Nation 2010, paras. 97-98)

This being stated, Justice Deschamps went on to describe conditions limiting the applicability of the duty to consult. She argued that the duty to consult only applies where no treaty exists (as in Haida) or where the text of a treaty, whether modern or historic, does not provide consultation protocols. When consultation is provided for in a treaty, said Justice Deschamps, the duty to consult moves from a protection against the infringement of Aboriginal and treaty rights to the exercise of treaty rights. (Beckman v. Little Salmon/Carmacks First Nation 2010, para. 94) Applying this logic, she found that Chapter 12 of the Little Salmon/Carmacks First Nation Final Agreement included First Nation participation in development assessment processes, which, she argued, constituted a consultation policy under the modern treaty. However, she noted that the this process had not yet come into force, raising serious questions about the discrepancy between treaty rights on paper and the real-world exercise of those rights. (Beckman v. Little Salmon/Carmacks First Nation 2010, para. 92; Bankes 2010, 2; see also Newman 2011, 477)

Justice Deschamps contended that applying the duty to consult and accommodate to all the Crown's relations with Indigenous peoples, as Justice Binnie had argued for the majority of the Court, 
...would be to defeat the very purpose of negotiating a treaty. Such an approach would be a step backward that would undermine both parties' mutual undertakings and the objective of reconciliation through negotiation. [...] Associating the honour of the Crown with the observance of duly negotiated treaties implies that some value is placed on the treaty negotiation process. But for the treaty to have real legal value, its force must be such that neither of the parties disregard it. [...] To allow one party to renege unilaterally on its constitutional undertaking by superimposing further rights and obligations relating to matters already provided for in the treaty could result in a paternalistic legal contempt, compromise the national treaty negotiation process and frustrate the ultimate objective of reconciliation. (Beckman v. Little Salmon/Carmacks First Nation 2010, paras. 91, 106-107)

This position is troubling, since the language of "reneging" is rarely, if ever, used to describe the conduct of Indigenous treaty partners, (Newman 2011, 482) particularly when considering the Crown's long history of treaty infringement. Still, this plays into the Justice's argument that "Legal certainty is the primary objective of all parties to a comprehensive land claim agreement." (Beckman v. Little Salmon/Carmacks First Nation 2010, para. 109) Justice Deschamps contended that legal certainty is not necessarily at odds with a relational understanding of treaties, since the treaty itself captures a relationship, the terms of which can be subject to review and amendment depending on the content of the agreement. "Certainty" in this context implies that the parties to the treaty are clear on the duties that must be discharged and the rights that each party holds, and this certainty cannot be obtained if these understandings are not agreed upon, allowing one party to act unilaterally. (Beckman v. Little Salmon/Carmacks First Nation 2010, paras. 111-112)

Considering the respective positions of the Justices in the Little Salmon/Carmacks decision, the disagreement between Binnie and Deschamps speaks to two fundamentally different views of the Crown's duties in maintaining treaty relationships with Indigenous peoples. These are, respectively, "covenantal" and "contractual" approaches to treaties. Dwight Newman describes the former: 
[Treaties are not] based just on positivist law but also on the requirements of morality $[\ldots]$ between communities. To think of treaties as "covenants" is to think of them in a manner building on a series of other scholarly conceptions while also acknowledging the spiritual views of Aboriginal communities as a perspective held by some treaty partners and ultimately thinking of treaties as agreements about foundational relationships between communities that have a fundamentally moral character to them. A covenantal conceptualization of treaties would essentially see them as agreements between political communities expressing the terms of the ongoing evolution of relationships between those communities. (Newman 2011, 485-86)

Newman echoes Justice Binnie by saying that a covenantal conception of treaties does not mean ignoring the express terms of the treaties themselves, but the spirit in which treaties are interpreted differs from the contractual approach. Where the latter seeks to apply treaty law according to its express terms and resolve ambiguity using technical legal doctrines, the former applies treaties as instruments of cooperation between communities. In contrast to contractual interpretations, the covenantal approach is concerned with establishing the terms of a long-term relationship that recognizes the intrinsic value of each party. Newman argues that the duty to consult and accommodate, if applied to all Crown-Indigenous relations, is a key element of this covenant. (Newman 2011, 486, 490)

Audra Simpson's work also highlights that Indigenous peoples have a key role to play in resisting contractual interpretations of treaty law. Contractual interpretations, she says, entrench the dispossession of Indigenous peoples under the guise of consent, given that the written text of treaties - and historic treaties in particular - do not capture the complete understanding of Indigenous signatories. (see also Grammond 2016b, 818) Simpson argues that Indigenous parties would never have signed treaties in the first place if they were knowingly consenting to the surrender of their lands. (Simpson 2017,27) That being the case, it is the duty of contemporary Indigenous advocates to "refuse" this interpretation which seeks to legitimize dispossession by 
the state, and push for the affirmation of inherent rights by settler governments as a matter of fundamental justice. (Simpson 2017, 20-21)

Critics of the Supreme Court have remarked that while Justice Binnie in the Little Salmon/Carmacks decision emphasized the importance of treaties as the legal basis for long-term Crown-Indigenous relationships, his point was undercut by his subsequent observation that modern treaties were "designed to place Aboriginal and non-Aboriginal relations in the mainstream legal system with its advantages of continuity, transparency, and predictability." (Beckman v. Little Salmon/Carmacks First Nation 2010, para. 12; Tzimas 2011b, 509) Nigel Bankes argues that this is a missed opportunity by the Court to build a body of inter-societal law informed by both Indigenous and common law traditions. Rather, gaps in the Little Salmon/Carmacks Final Agreement were effectively filled by settler law. (Bankes 2010, 6)

Bankes further concludes that at the low end of the consultation spectrum, there is little substantive difference between the duty to consult and administrative law duties of procedural fairness. This is because procedural fairness never entitles affected parties to a particular outcome, nor does the duty to consult. (Bankes 2010, 3-4) Similarly, the duty to accommodate has generally become associated under common law with the deeper end of the consultation spectrum, when the infringement of Aboriginal and treaty rights is deemed more serious. (Promislow 2013b, 66)

Given that the duty to consult has no greater legal content than the duty of procedural fairness at the low end of the consultation spectrum, (see Sossin 2010b) Bankes concludes that this is not consistent with the honour of the Crown and the Supreme Court's stated goal of intersocietal reconciliation. To remedy this, Bankes argues that the principle of "demonstrable integration" - taken from the 1999 Halfway River First Nation v. BC case, and reiterated by the 
Supreme Court in Mikisew (at para. 64) - should be applied to all levels of Crown-Indigenous consultation, such that the Crown provides written evidence that it has integrated Indigenous concerns into project implementation, with a view to minimizing its impacts. Further, Bankes suggests the Crown should provide to Indigenous partners an assessment of cumulative impacts of a project over time, rather than its immediate impacts. These elements, Bankes says, would give the duty to consult more legal content than simple duties of administrative law. (Bankes 2010,5)

Ria Tzimas argues that the Court's conception of reconciliation places great faith in the ability of Indigenous and non-Indigenous parties to reach agreement over the shared use of resources. Tzimas remarks that while economic self-sufficiency is an essential component of reconciliation, and some Indigenous peoples do actively participate in resource exploitation projects, the Crown cannot assume this alignment of development goals. Indigenous cultures and well-being are inextricably connected to the land, and this may produce fundamentally different visions of how resources ought to be used. (Tzimas 2011b, 514-15) Government consultations must develop strategies that prepare for such an outcome.

The vision of consultation articulated by the Supreme Court in Little Salmon/Carmacks is fundamentally forward-looking, and has difficulty addressing compensation for past injustices outside of crafting new agreements. (Promislow 2013b, 67) As stated by Justice Binnie, "The treaty is as much about building relationships as it is about the settlement of ancient grievances. The future is more important than the past. A canoeist who hopes to make progress faces forwards, not backwards.” (Beckman v. Little Salmon/Carmacks First Nation 2010, para. 10)

While the Little Salmon/Carmacks decision provided little advancement over the previous Mikisew decision regarding the content of the duty to consult and accommodate, it 
remains important as a restatement of the duty's broad scope, and as an application of the duty to territorial governments in Canada. Justice Binnie and Justice Deschamps may have disagreed on how the duty to consult may apply in the context of a modern treaty, but the majority of the Court held that the honour of the Crown infuses all relations between the Crown and Indigenous peoples, dating back to promises made in the Royal Proclamation of 1763 and the 1764 Treaty of Niagara. (see Borrows 1997f). Treaties, whether historic or modern, only give greater definition to inherent rights that Canada's Indigenous peoples already hold. (see Jai 2009, 46-47, 58-61)

\section{Grassy Narrows (2014)}

The Supreme Court's decision in the 2014 Grassy Narrows v. Ontario case again considered the honour of the Crown and the "taking up" of land for development, providing key findings for the conduct of provincial governments generally, and the Province of Ontario specifically. (Young, Annibale, and Ryan 2014, 4) The facts of the case were relatively simple. In 1997 the Ontario Ministry of Natural Resources licensed a large pulp and paper manufacturer, Resolute Forest Products, to conduct clear-cut logging on Crown lands in the Keewatin region of northwestern Ontario, which includes Treaty 3 territory. In 2005, the Grassy Narrows First Nation, descendants of the Ojibway signatories of Treaty 3, took Ontario to court on the grounds that the provincial government had no authority to "take up" lands in the Keewatin region since, for reasons outlined below, it was claimed as federal Crown land at the treaty signing in 1873. As such, Grassy Narrows contended that Ontario had no authority to infringe, even justifiably, on their harvesting rights guaranteed under treaty, and had to seek federal approval to do so. (Grassy Narrows First Nation v. Ontario (Natural Resources) 2014, paras. 18-19) 
In the immediate wake of Confederation, the Government of Canada wanted to facilitate the construction of a transcontinental railway, and so pursued treaty negotiations with the Ojibway in what is now northwestern Ontario and southeastern Manitoba. Ojibway chiefs were in no rush to make a deal as there were still very few settlers in their territories, and negotiations were tried and failed in both 1871 and 1872. After Canada appointed new treaty commissioners, Treaty 3 was negotiated over three days in October 1873. At trial many contemporary accounts of the negotiations were heard, including the handwritten notes of one of the treaty commissioners, Simon Dawson, discussions published in The Manitoban newspaper, and the notes of a Métis secretary to the Ojibway chiefs published in the Manitoba Free Press. (Grassy Narrows First Nation v. Ontario (Natural Resources) 2014, paras. 6-10)

Similar to the text of Treaty 8 considered in Mikisew, Treaty 3 also subjected guarantees of harvesting rights to a "taking up" clause, which was worded as follows:

[T] hey, the said Indians, shall have [the] right to pursue their avocations of hunting and fishing throughout the tract surrendered [...] and saving and excepting such tracts as may, from time to time, be required or taken up for settlement, mining, lumbering or other purposes by Her said Government of the Dominion of Canada, or by any of the subjects thereof duly authorized therefor by the said Government. (Treaty 3 1873, 6 as quoted in Grassy Narrows First Nation v. Ontario (Natural Resources) 2014, para. 11)

At the time of the treaty signing, the Keewatin region was the subject of a territorial dispute between the Province of Ontario and the Government of Canada, and only Canada was party to the treaty. However, the following year the two governments reached a provisional boundary agreement, and in 1912 the Ontario Boundaries Extension Act transferred the Keewatin territory from the federal government to the provincial government. (Grassy Narrows First Nation v. Ontario (Natural Resources) 2014, paras. 40, 43) 
An 1894 Agreement between Ontario and Canada contained provisions that, with the exception of reserve lands, authorized the provincial government to take up Treaty 3 territory:

[I]n the said treaty mentioned, it is hereby conceded and declared that, as Crown lands in the surrendered tract have been decided to belong to the Province of Ontario, or to Her Majesty in right of the said Province, the rights of hunting and fishing by the Indians throughout the tract surrendered, not including the reserves to be made thereunder, do not continue with reference to any tracts which have been, or from time to time mat be, required or taken up for settlement, mining, lumbering or other purposes by the Government of Ontario, or persons duly authorized by the said government of Ontario. (Grassy Narrows First Nation v. Ontario (Natural Resources) 2014, para. 41)

Evidently, the 1894 Agreement closely mirrored the language on the "taking up" clause in Treaty 3. It is worth noting, however, that this was a transfer of powers between settler governments, and the Grassy Narrows First Nation argued at trial that this effectively changed the terms of the treaty by unilaterally changing one of the treaty parties. In the trial judge's reading of Treaty 3, the federal power over "Indians and lands reserved for Indians" under Section 91(24) of the Constitution Act, 1867 (the British North America Act) firmly placed Treaty 3 under federal jurisdiction, and thus Ontario would need to seek federal approval to "take up" treaty territory. (see Seymour 2014, 31)

This verdict was then overturned by the Ontario Court of Appeal, which argued that there was no evidence, either in Treaty 3 or in other historical accounts, that either treaty party contemplated a two-step process. Turning to the Constitution Act, 1867 (as the British North America Act came to be called after Patriation), the Court of Appeal found that Section 92(5) allowed to the provincial government to sell public lands in its territory, Section 92A authorized provincial governments to pass legislation relating to natural resources, and Section 109 granted natural resource revenues to provincial governments, subject to any existing trusts, Treaty 3 among them. (Grassy Narrows First Nation v. Ontario (Natural Resources) 2014, paras. 21-22) 
Considering the jurisdictional questions that Grassy Narrows placed before the Supreme Court, and in light of the relational treaty interpretations argued by Indigenous appellants in the Mikisew and Little Salmon/Carmacks cases, it is interesting to note that the First Nation chose in this case to rely on a strict textual reading of Treaty 3, accepting that Canada, but not Ontario, was entitled to "take up" treaty territory. (Townshend 2017, 464) In his analysis, Roger Townshend argues that central to the Grassy Narrows case was whether the Crown itself was a party to Treaty 3 , or whether it was the Government of Canada. He points to the doctrine of "constitutional evolution" used by the Ontario Court of Appeal in this case, which argues that as the nature of federalism changes over time, so too does the exercise of the Crown's duties. As the Court of Appeal explained:

Throughout that process of constitutional evolution, the Crown and the relationship between the Crown and Canada's Aboriginal peoples remains a constant, central, and defining feature. What has evolved is the allocation of legislative and administrative powers and responsibilities to different levels of government. In formal terms, what changes with constitutional evolution is the level of government on whose advice the Crown acts. (Keewatin v. Ontario 2013, para.136 as quoted in Townshend 2017, 464-65)

As seen previously in Chapter 3, the English Court of Appeal used a similar logic in 1982, when the Indian Association of Alberta contended that treaties were signed with the British Crown, precluding Canada from exercising authority over treaty law under a patriated constitution without the assent of the Queen. Then, as now, the English Court concluded that the British Crown had split from the Crown in right of Canada, and in so doing the latter had become a party to treaties with Indigenous peoples. (Townshend 2017, 465-66; see also Sanders 1983b,

The Supreme Court agreed with the reasoning of the Ontario Court of Appeal that Canada's constitutional provisions under Sections 91(24), 92(5), 92A, and 109 of the 
Constitution Act, 1867 empowered the Province of Ontario to "take up" lands in Treaty 3 territory. (Grassy Narrows First Nation v. Ontario (Natural Resources) 2014, paras. 30-31, 3537; Young, Annibale, and Ryan 2014, 3) Turning specifically to the 1894 Canada-Ontario Agreement and the 1912 Ontario Boundary Extension Act, the Court held that while the legislation transferred beneficial ownership of the Keewatin territory from Canada to Ontario, authorizing the Province to "take up" treaty lands, both laws contained specific provisions that Ontario's beneficial ownership was subject to Aboriginal and treaty rights already guaranteed in the territory.(Grassy Narrows First Nation v. Ontario (Natural Resources) 2014, paras. 42-44)

Fundamentally, the Supreme Court ruled that neither of these pieces of legislation modified the parties to Treaty 3 . This stems from how the Court conceived of the role of the Crown:

The view that only Canada can take up or authorize the taking up of lands under Treaty 3 rests on a misconception of the legal role of the Crown in the treaty context. It is true that Treaty 3 was negotiated with the Crown in right of Canada. But that does not mean that the Crown in right of Ontario is not bound by and empowered to act with respect to the treaty. [...] The treaty, as discussed, was between the Crown - a concept that includes all government power - and the Ojibway. [...] The 1912 Legislation altered which level of government would have authority in terms of taking up the land. It did not modify the treaty or change its partners. (Grassy Narrows First Nation v. Ontario (Natural Resources) 2014, paras. 32, 39, 49)

Anishinaabe lawyer and Treaty 3 beneficiary, Janine Seymour, argues that the Supreme Court in Grassy Narrows privileged settler understandings of treaty law in a way that facilitates resource development and entrenches Indigenous-settler dichotomies of treaty interpretation. (Seymour 2014, 32). While I cannot comment on Indigenous understandings of Treaty 3, I respectfully disagree that the decision facilitates resource development on treaty lands. I would argue that a unified conception of the Crown better exemplifies the nation-to-nation compact at 
the heart of the treaty relationship. True, a two-step process requiring federal authorization of provincial conduct in treaty territory, as contemplated by the trial judge in Grassy Narrows, would add an additional check on the exercise of provincial power. But a unified Crown subjects provincial governments to all the Crown's attendant duties of honourable dealing, which raises the overarching standard for provincial conduct. No longer can provincial governments claim that Aboriginal and treaty rights lie beyond their jurisdiction while land and resource projects proceed. As held by the Supreme Court:

In exercising its jurisdiction over Treaty 3 lands, the Province is bound by the duties attendant on the Crown. It must exercise its powers in conformity with the honour of the Crown, and is subject to the fiduciary duties that lie on the Crown in dealing with Aboriginal interests. [...] When a government - be it the federal or a provincial government - exercises Crown power, the exercise of that power is burdened by the Crown obligations toward the Aboriginal people in question. [...]

Where [Ontario] intends to take up lands for the purposes of a project within its jurisdiction, the Crown must [...] deal with the Ojibway in good faith, and with the intention of substantially addressing their concerns. [...] Not every taking up will constitute an infringement of the harvesting rights set out in Treaty 3 . This said, if the taking up leaves the Ojibway with no meaningful right to hunt, fish, or trap in relation to the territories over which they traditionally hunted, fished, and trapped, a potential action for treaty infringement will arise. (Grassy Narrows First Nation v. Ontario (Natural Resources) 2014, paras. 50, 52 emphasis added)

This last point regarding the "meaningful right to hunt" builds on the Court's previous ruling in Mikisew (at para. 48), and imposes important limits on provincial entitlements to "take up" treaty lands. A significant impact on harvesting rights, even if these impacts were localized, would be a breach of the Crown's fiduciary duties under treaty, and the provincial Crown would now have to justify such an infringement using the Sparrow test. (Bankes 2015, 215-16; Young, Annibale, and Ryan 2014, 2) Subjecting provincial governments to the honour of the Crown should encourage practices of Crown-Indigenous negotiation instead of the litigation that would surely follow continued jurisdictional disputes. This argument is further developed below in 
relation to the Tsilhqot'in v. $B C$ decision, which acts as a companion case for Grassy Narrows with respect to untreatied lands. (see McIvor 2015, 19)

The Supreme Court's unanimous decision in Grassy Narrows resolved any ambiguity over the Court's view of shared jurisdiction with respect to Aboriginal and treaty rights. ( $C B C$ News 2014, 1; Seymour 2014, 31) In so doing, it also produced greater certainty for resource and energy project proponents, as it clarified responsibilities for which order of government must discharge the duty to consult and accommodate, and reinforced provincial licensing powers in areas under Numbered Treaties. (Seymour 2014, 30-31) The latter is less clear on unceded lands (or some modern treaty areas) where provincial Crown sovereignty is contested or contingent, which ought only to increase the importance of seeking Indigenous consent. (Coates and Newman 2014, 15) While the Grassy Narrows decision bore little fruit for the Grassy Narrows First Nation, the ruling remains critically important to the judicial dialogue on treaty rights. When read alongside the Tsilhqot'in v. $B C$ decision, to be discussed presently, the two cases set remarkable new precedents which move beyond siloed federal jurisdiction over Aboriginal and treaty rights, and carve out a more significant role for provincial governments in renewing and maintaining Crown-Indigenous relationships.

\section{The Relevance of Tsilhqot'in to the Grassy Narrows Decision}

The Supreme Court's 2014 decision in Tsilhqot'in Nation v. British Columbia was released only weeks before Grassy Narrows. Tsilhqot'in relates specifically to Indigenous territories not covered under modern or historic treaties, but the ruling continues to be relevant to provincial policy in Ontario, even though virtually all of the province's territory has been covered under pre-Confederation land purchases, post-Confederation Numbered Treaties, and most recently an Agreement in Principle forerunning a modern treaty. It should be noted that 
many pre-Confederation land purchases were not signed by all Indigenous peoples who lived in those territories. As such, peoples not party to these treaties hold that their sovereign authority remains intact, and large portions of Manitoulin Island and the Ottawa valley, for example, are considered unceded territory. (Coates and Newman 2014, 13; Bankes 2015, 189; see also "Map of Ontario treaties and reserves", Government of Ontario n.d.)

Aside from the treatment of unceded lands by provincial governments, the Tsilhqot'in case also provided important legal guidance on Aboriginal land title and the doctrine of "interjurisdictional immunity" which was pivotal in requiring the honourable conduct of the provincial Crown.

Interjurisdictional immunity, or IJI, is essentially common law terminology for the provincial compact theory described in Chapter 3. It holds that the heads of federal and provincial power outlined in Sections 91 and 92 of the Constitution Act, 1867 are integral to each level of government's legislative authority. As such these jurisdictions are immune from application by the other order of government, and legislation beyond each government's purview can be struck down by the judiciary. (McIvor and Gunn 2016, 149; Townshend 2017, 473-74)

The Tsilhqot'in case was the final product of 20 years of litigation (see Coates and Newman 2014, 10-11) in which the Tsilhqot'in Nation challenged the authority of the Province of British Columbia to pass legislation regulating forestry on the unceded territory of the Tsilhqot'in people, located in the province's central interior. The Tsilhqot'in argued that the doctrine of interjurisdictional immunity precluded the Province from passing legislation infringing upon their Aboriginal rights, which they held could only be justified by the federal Crown pursuant to Section 91(24). (Tsilhqot' in Nation v. British Columbia 2014, paras. 257, 262; McIvor and Gunn 2016, 154-55) 
The Supreme Court's conception of Aboriginal land title prior to Tsilhqot'in rested on criteria outlined in the 1997 Delgamuukw v. BC decision, in which the Court argued that a title claim would have to be based in (1) occupation of the land prior to the assertion of Crown sovereignty, (2) continuity between present occupation and pre-sovereignty occupation, and (3) exclusive occupation at the assertion of Crown sovereignty. The Court remained silent on the nature of "occupation" which would suffice to establish title, and never had occasion to apply a title test until Tsilhqot'in. (Bankes 2015, 190-91) The 2014 case expanded the definition of title outlined in Delgamuukw to allow for seasonal land use by Indigenous peoples and considered that "exclusive" occupation could include territories which overlapped those of neighbouring peoples, so long as the occupation by communities in question was recognized by others. Using this definition, "non-exclusive occupation" would still provide for Aboriginal rights, such as harvesting, but would not be sufficient to assert land title. (Coates and Newman 2014, 12-13)

Having expanded the common law definition of Aboriginal title, the Supreme Court's finding that the Tsilhqot'in Nation retained title to the majority of its claimed territory produced the first ever judicial declaration of Aboriginal title in Canada. (Coates and Newman 2014, 5; McIvor 2015, 10) In his analysis of the decision, Kent McNeil points out that in contrast to the honour of the Crown, which applies to government conduct even where Aboriginal and treaty rights are unrecognized, the burden of proving Aboriginal land title is still placed on Indigenous peoples themselves. (McNeil 2015, 69)

Turning to the content of Aboriginal title, McNeil considers the opinion of Chief Justice Beverley McLachlin. She writes:

[The] content of the Crown's underlying title is what is left when Aboriginal title is subtracted from it. [...] Provincial laws of general application, including the Forest Act, should apply unless they are unreasonable, impose a hardship or deny 
the title holders their preferred means of exercising their rights, and such restrictions cannot be justified pursuant to the justification framework outlined above. The result is a balance that preserves the Aboriginal right while permitting effective regulation of forests by the province, as required by s. 35 of the Constitution Act, 1982. (Tsilhqot'in Nation v. British Columbia 2014, paras. 70, 151)

The Chief Justice's reasoning is in line with established common law "principles of continuity" dating back to British Imperial Law, which hold that until the Crown enacted legislation altering a local law, local laws and customs were deemed to remain in force. (Walters 1999, 715) But, says McNeil, the Court's declaration of Aboriginal title did not create title for the Tsilhqot'in, but rather recognized it as pre-dating colonization and the assertion of Crown sovereignty. This is consistent with the principle that Aboriginal title is an inherent right, not delegated from the Crown. It also firmly placed Aboriginal title as an "existing" right under Section 35. How then, asks McNeil, can a right exist unextinguished - thus allowing it to be recognized and affirmed under Section 35 - and yet beneficial title to the land be unvested in the Indigenous people in question? Likewise, how did beneficial title to the land come to be vested in the Crown prior to proof underlying of Aboriginal title? (McNeil 2015, 72-73) If the assertion of Crown title is contested, the extraction of natural resources from unceded territories amounts to expropriation, McNeil argues. As a compromise, McNeil suggests that provincial regulations of general application could be considered applicable insofar as they protect Aboriginal rights through environmental protection or the control of invasive species, but that any resource extraction would only be lawful upon obtaining Indigenous consent. (McNeil 2015, 84) McNeil's position is similar to that taken by Chief Justice McLachlin. She writes:

General regulatory legislation, such as legislation aimed at managing the forests in a way that deals with pest invasions or prevents forest fires, will often pass the Sparrow test as it will be reasonable, not impose undue hardship, and not deny the holders of thee right their preferred means of exercising it. In such cases, no 
infringement will result. (Tsilhqot'in Nation v. British Columbia 2014, para. 123; see also McNeil 2015, 84-85)

Prior to the Tsilhqot'in decision, the Supreme Court had identified in Delgamuukw three sui generis qualities of Aboriginal title which distinguished it from fee simple land ownership (i.e. real property). In that case, Justice Lamer wrote that Aboriginal title (1) is inalienable except to the Crown, (2) arises from Indigenous legal orders and ancestral occupation prior to the assertion of Crown sovereignty, and (3) is held communally. (Delgamuukw v. British Columbia 1997b, paras. 112-115; see also Bankes 2015, 192) Building upon the reasoning of Justice Lamer, Chief Justice McLachlin wrote in Tsilhqot'in that:

Aboriginal title confers ownership rights similar to those associated with fee simple, including: the right to decide how the land will be used; the right of enjoyment and occupancy of the land; the right to possess the land; the right to the economic benefits of the land; and the rights to pro-actively use and manage the land.

Aboriginal title, however, comes with an important restriction - it is collective title held not only for the present generation but for all succeeding generations. This means it cannot be alienated except to the Crown or encumbered in ways that would prevent future generations of the group from using or enjoying it. Nor can the land be developed or misused in a way that would substantially deprive future generations of the benefit of the land. (Tsilhqot'in Nation v. British Columbia 2014, paras. 73-74; see also Coates and Newman 2014, 14; McNeil 2015, 67)

From the Chief Justice's remarks, McNeil points out that requiring the preservation of land use for future generations acts as an important check on the Crown, limiting their ability to justify infringements of Aboriginal title. This is stated explicitly by Chief Justice McLachlin:

[T] he Crown's fiduciary duty means that the government must act in a way that respects the fact that Aboriginal title is a group interest that inheres in present and future generations. The beneficial interest in the land held by the Aboriginal group vests communally in the title-holding group. This means that incursions on Aboriginal title cannot be justified if they would substantially deprive future generations of the benefit of the land. (Tsilhqot'in Nation v. British Columbia 2014, para. 86; see also McNeil 2015, 68) 
The corollary of this position, however, is that Indigenous peoples holding Aboriginal title may face hurdles if they choose to develop their own lands. Lenders or private sector partners will likely seek assurances that the proposed development is consistent with the interests of future generations. Nigel Bankes suggests that one way to provide such assurances might be participatory land use planning in which the Indigenous community offers collective decisions about land use and development. (Bankes 2015, 205-6) In other words, private sector partners will want to be sure they obtain the consent of the community. Does this pursuit of Indigenous consent extend to the Crown? Tsilhqot'in offered some guidance in this respect.

The ruling began to introduce the language of consent, over and above the duty to consult and accommodate - though it is important to note that the Court stopped short of making consent a legal requirement. Coates and Newman remark that the duty to consult is triggered at a relatively low threshold - any time the federal, provincial, or territorial Crown contemplates action which may affect Aboriginal rights or treaty rights. (Coates and Newman 2014, 16) In the context of Aboriginal title, the duty covers most areas of land use and resource planning. But as has been highlighted throughout the last chapter and this one, consultation and accommodation does not require agreement, which makes Indigenous consent a much higher bar to meet.

The Court thus separated proven title from unproven title in the way it approached consent. In cases where the land title of an Indigenous people is not yet recognized by the Crown, the duty to consult and accommodate continues to apply. After the recognition of Aboriginal title by court declaration or agreement, the Crown would need to further justify an infringement using the Sparrow test if it lacked the consent of the title-holders. Furthermore, this test could apply retroactively. As the Chief Justice wrote: 
[O]nce title is established, the Crown cannot proceed with development of title land not consented to by the title-holding group unless it has discharged its duty to consult and the development is justified pursuant to s. 35 of the Constitution Act, 1982.

Once title is established, it may be necessary for the Crown to reassess prior conduct in light of the new reality in order to faithfully discharge its fiduciary duty to the title-holding group going forward. For example, if the Crown begins a project without consent prior to Aboriginal title being established, it may be required to cancel the project upon establishment of the title if continuation of the project would be unjustifiably infringing. Similarly, if legislation was validly enacted before title was established, such legislation may be rendered inapplicable going forward to the extent that it unjustifiably infringes Aboriginal title.

(Tsilhqot'in Nation v. British Columbia 2014, paras. 91-92)

The Court's approach in Tsilhqot'in still placed the burden of proving Aboriginal title on Indigenous peoples, rather than the Crown having to prove how it came to acquire title; and in this respect the ruling is somewhat limited in scope. However, the proactive and retroactive requirement of justifiable infringement upon recognition of Aboriginal title acts as an important check on the exercise of the Crown's authority. More to the point, introducing Indigenous consent into the jurisprudence on Aboriginal and treaty rights further moves the needle towards the settler recognition of Indigenous sovereignty.

Another key outcome of the Tsilhqot'in decision, particularly as it applied to Grassy Narrows a few weeks later, was the view taken by the Court on the "doctrine of interjurisdictional immunity". The Court in Tsilhqot 'in departed from earlier jurisprudence in the 2006 R. v. Morris decision, in which the Indigenous appellants challenged the hunting regulations under British Columbia's Wildlife Act on the basis that its application to Indigenous peoples violated the federal-provincial division of powers. Both the majority and the dissenting opinion in Morris held that if provincial legislation (such as BC's Wildlife Act) created a prima facie infringement of Aboriginal and treaty rights, the law would be rendered inapplicable due to federal jurisdiction over "Indians, and lands reserved for Indians" under Section 91(24) of the 
Constitution Act, 1867. The reasoning was that provincial laws could not affect the nature of

"Indianness", could not accord "Indians" particular treatment, or affect "Indian" land interests.

(R. v. Morris, 2006 paras. 41-3, 82, 88-90, 99 as cited in Townshend 2017, 475-76)

The Court in Tsilhqot'in, however, specifically broke from the precedent in Morris.

Writing for a unanimous Court, (McNeil 2015, 67) Chief Justice McLachlin held:

To the extent that Morris stands for the proposition that provincial governments are categorically barred from regulating the exercise of Aboriginal rights, it should no longer be followed. I find that, consistent with the statements in Sparrow and Delgamuukw, provincial regulation of general application will apply to exercises of Aboriginal rights, including Aboriginal title land, subject to the $\mathrm{s}$. 35 infringement and justification framework. This carefully calibrated test attempts to reconcile general legislation with Aboriginal rights in a sensitive way as required by s. 35 of the Constitution Act, 1982 and is fairer and more practical from a policy perspective than the blanket inapplicability imposed by the doctrine of interjurisdictional immunity. (Tsilhqot'in Nation v. British Columbia 2014, para. 150)

McIvor and Gunn argue that the view of Sec. 91(24) articulated in Tsilhqot'in marks a major shift in judicial dialogue on Aboriginal and treaty rights. Where prior to 2014, the Court upheld Sec. 91(24) as a tool for protecting a vulnerable population in Canadian society, post2014 jurisprudence tended to think of the section as central to the control and colonization of Indigenous peoples by the federal government. (McIvor and Gunn 2016, 149, 151-52; see also Bankes 2015, 193) This shift in judicial dialogue echoes a shift in the federal-provincial compact. McIvor and Gunn point out that the original purpose of Sec 91(24) was to place the federal Crown between Indigenous peoples and local settler populations. Provincial governments, with their powers over - and ties to - the resource sector, face increased pressure from local populations to develop resources. This may bias them against honourable dealing with Indigenous peoples. (McIvor and Gunn 2016, 159-62) This position dates back to pre- 
Confederation Canada. In reference to Indigenous populations in British Colonies, the 1837

Report of the Select Committee on Aborigines stated that:

The protection of the Aborigines should be considered a duty particularly belonging and appropriate to the executive government, as administered either [by the Imperial Parliament] or by the governors of the respective colonies. This is not a trust which could conveniently be confided to the local legislatures. [...] [T] he settlers in almost every colony, having either disputes to adjust with the native tribes, or claims to urge against them, the representative body is virtually a party, and therefore ought not to be the judge in such controversies. (as quoted in McIvor and Gunn 2016, 147)

As Townshend argues, a strict constitutional interpretation of the division of powers in Canadian federalism carries with it other baggage of an old body of Aboriginal law which denies the land rights of Indigenous peoples, privileges a literal and textual reading of treaties including the surrender and extinguishment of land title, and is marked by the absence of constitutional remedies for a breach of treaty promises. The "new" Aboriginal law as exemplified by the Tsilhqot'in and Grassy Narrows decisions, says Towshend, is premised on treaties as an exchange of solemn promises, the Crown's duty of honourable dealing, the consideration of unwritten evidence, and the reconciliation of the respective interests of Indigenous and settler populations as consistent with treaty promises. (Townshend 2017, 461-62) This does not amount to a repeal of Sec 91(24), says Townshend, since provincial legislation is still not empowered to extinguish Indigenous land interests, both because of the division of powers and guarantees under Sec. 35. (Townshend 2017, 481; see also Bankes 2015, 200, 212) The inclusion of the provincial Crown in duties of honourable dealing, Townshend argues, is more consistent with a cooperative approach to federalism (Townshend 2017, 480) which emphasizes partnership and mutual responsibility over the jealous guarding of jurisdiction.

True, the changing judicial discourse in Tsilhqot'in does not necessarily prevent provincial government from infringing upon treaty rights, and so it may be useful to recall 
exactly what the provincial Crown must justify under a justifiable infringement test. The Crown must show that (1) the infringement of treaty rights or Aboriginal title is necessary to achieve the Crown's objectives, (2) the infringement goes no farther than necessary to achieve the Crown's objectives, and (3) the expected public benefits of infringement are not outweighed by the adverse impact on the affected Indigenous peoples. (Tsilhqot' in Nation v. British Columbia 2014, paras. 79-80, 87; see also Townshend 2017, 471-72) The justifiable infringement test laid out in Tsilhqot'in fits into a broader body of rights law in Canada. Like the infringement of rights recognized under Sec. 35, the infringement of rights outlined in the Charter of Rights and Freedoms are subject to the Sec. 1 "reasonable limits" clause, which guarantees Charter rights "subject only to such reasonable limits as can be demonstrably justified in a free and democratic society." (Canada 1982b)

As in Tsilhqot'in, the Supreme Court also laid out three elements of a Sec. 1 justification test in the 1986 R. v. Oakes decision, namely a rational connection to the Crown's objectives, the minimal impairment of rights, and the proportionality of the impact of infringement. (R. v. Oakes 1986, paras. 136-138 as cited in Townshend 2017, 472-73) It can be convincingly argued that Crown never acquired the legal authority to infringe upon the inherent rights and title of Indigenous peoples. But the similarity of the Court's findings in Aboriginal title cases and Charter jurisprudence merely demonstrates that the Supreme Court holds no rights to be absolute. In the absence of absolute rights, the alternative is a relationship of negotiation between parallel Crown and Indigenous sovereignties.

Coates and Newman argue that the Supreme Court's walk-back of interjurisdictional immunity opens policy space for bilateral relations between Indigenous nations and provincial governments without thee necessity of a federal interlocutor. Provinces are closer to the land and 
resource issues affecting inherent rights and title, and bilateral talks are often less costly, timeconsuming, and complex than tripartite negotiations. The Tsilhqot'in ruling, they say, ought to be interpreted as the Supreme Court's endorsement of an equitable place for Indigenous peoples in land use planning and development on their traditional lands. (Coates and Newman 2014, 21-22) A siloed approach to federal-provincial jurisdiction pulls government attention away from Indigenous concerns and toward division-of-powers questions. This is not consistent with the relationships outlined in treaties, and the Supreme Court's recent findings are a reflection of that.

\section{Conclusion}

While the Supreme Court has repeatedly favoured negotiated solutions to the reconciliation of parallel sovereignties, the four cases outlined in this chapter each developed upon the ideas of Haida Nation and Taku River, expanding the application of the duty to consult and accommodate to all the Crown's relations with Indigenous peoples, including historic and modern treaties, and underscoring the important role of provincial and territorial governments to fulfill the honour of the Crown alongside their federal counterpart. These cases demonstrate that common law remedies can be of instrumental use to advancing the settler recognition of Indigenous sovereignty. As Coates and Newman argue,

$[\mathrm{T}]$ he reality is that Aboriginal people and governments are simply asking the courts to ensure that Canadian (and British) law is applied equitably and fairly to their situations. In contrast to those who are sharply critical of the "activist" court, the judges of the Supreme Court are simply doing the job they are required to do by section 35 of the Constitution Act, 1982, deciding if and when governments (or, possibly, others) have infringed on Aboriginal rights. The process is a vital one, for both Aboriginal people and for all Canadians. [...] Aboriginal claimants have driven the court to define specific rights, gradually building an edifice of territorial and resource rights that they can use to their economic, political, and cultural benefit. (Coates and Newman 2014, 9) 
Thanks to the efforts of Indigenous appellants, the jurisprudence outlined in this chapter and the last calls into question the surrender and extinguishment clauses contained in many treaties, and emphasizes the continuity of Aboriginal title. These cases impose limits to Crown conduct, and require duties of consultation and honourable dealing with Indigenous nations. The lack of an Indigenous veto may seem like a liability, but rather this ought to reinforce the notion that in a cooperative federation, no government can negate the legitimate interests of the other. All sovereign governments in Canada - federal, provincial, and Indigenous - must have an equal place at the policy development table.

In the next chapter, these judicial principles will be held up against Ontario's First Nation consultation policies to see how the law has been implemented in provincial government practice.

\section{References}

Bankes, Nigel. 2005. "Mikisew Cree and the Lands Taken Up Clause of the Numbered Treaties." Resources, no. 92/93 (Fall /Winter 2006). http://prism.ucalgary.ca/bitstream/1880/47047/1/Resources92-93.pdf.

- 2010. "Little Salmon and the Juridical Nature of the Duty to Consult and Accommodate." The University of Calgary Faculty of Law Blog on Developments in Alberta Law (blog). 2010. ablawg.ca/wpcontent/uploads/2010/12/blog_nb_salmon_dec2010.pdf.

- 2015. "The Implications of the Tsilhqot' in (William) and Grassy Narrows (Keewatin) Decisions of the Supreme Court of Canada for the Natural Resources Industries.” Journal of Energy \& Natural Resources Law 33 (3): $188-217$.

Beckman v. Little Salmon/Carmacks First Nation. 2010. Supreme Court of Canada.

Borrows, John. 1997. "Wampum at Niagara: The Royal Proclamation, Canadian Legal History, and SelfGovernment." In Aboriginal and Treaty Rights in Canada, edited by Michael Asch, 170. UBC Press. http://www.chiefs-of-ontario.org/sites/default/files/files/Borrows-WampumAtNiagara\%20(2).pdf.

Canada, Government of Canada; Indigenous and Northern Affairs. 1982. Constitution Act, 1982. https://lawslois.justice.gc.ca/eng/Const/page-16.html.

CBC News. 2014. “Grassy Narrows Loses Supreme Court Logging Rights Decision,” July 11, 2014. https:/www.cbc.ca/news/politics/grassy-narrows-loses-supreme-court-logging-rights-decision-1.2703123.

Coates, Kenneth, and Dwight Newman. 2014. "The End Is Not Nigh: Reason over Alarmism in Analysing the Tsilhqot'in Decision." Macdonald-Laurier Institute. 
Delgamuukw v. British Columbia. 19973 SCR 1010. Supreme Court of Canada.

Government of Ontario. n.d. "Map of Ontario Treaties and Reserves." Accessed February 28, 2020.

https://www.ontario.ca/page/map-ontario-treaties-and-reserves.

Grammond, Sebastien. 2016. “Compact Is Back: The Supreme Court Od Canada's Revival of the Compact Theory of Confederation.” Osgoode Hall Law Journal 53: 799-823.

Grassy Narrows First Nation v. Ontario (Natural Resources). 2014. Supreme Court of Canada.

Jai, Julie. 2009. "The Interpretation of Modern Treaties and the Honour of the Crown: Why Modern Treaties

Deserve Judicial Deference.” National Journal of Constitutional Law 26 (1): 25-65.

McIvor, Bruce. 2015. “First Peoples Law 2014.” First Peoples Law Corporation.

McIvor, Bruce, and Kate Gunn. 2016. "Stepping into Canada's Shoes: Tsilhqot'in, Grassy Narrows and the Division of Powers." University of New Brunswick Law Journal 67: 146-66.

McNeil, Kent. 2015. “Aboriginal Title and the Provinces after Tsilhqot'in Nation." Supreme Court Law Review 71: 67-89.

Mikisew Cree First Nation v. Canada (Minister of Canadian Heritage). 2005. Supreme Court of Canada.

Morellato, Maria. 2008. "The Crown's Constitutional Duty to Consult and Accommodate Aboriginal and Treaty Rights.” National Centre for First Nations Governance.

Newman, Dwight. 2011. “Contractual and Covenantal Conceptions of Modern Treaty Interpretation." Supreme Court Law Review 54: 475-91.

Promislow, Janna. 2013. "Irreconcilable? The Duty to Consult and Administrative Decision Makers." Constitutional Forum 22 (1): 63-78.

Sanders, Douglas. 1983. "The Indian Lobby.” In And No One Cheered: Federalism, Democracy and the Constitution Act, edited by Keith Banting and Richard Simeon, 301-32. Methuen Publications.

Schwartz, Bryan, and Darla L. Rettie. 2006. "The Long and Winding Road: Case Comment on Mikisew Cree First Nations v. Canada (Minister of Canadian Heritage).” Supreme Court Law Review 34: 465-75.

Seymour, Janine. 2014. “Casenote: Grassy Narrows First Nation v. Ontario (Natural Resources).” Indigenous Law Bulletin 8 (18): 30-33.

Simpson, Audra. 2017. "The Ruse of Consent and the Anatomy of 'Refusal': Cases from Indigenous North America and Australia." Postcolonial Studies 20 (1): 18-33.

Sossin, Lorne. 2010. "The Duty to Consult and Accommodate: Procedural Justice as Aboriginal Rights." Canadian Journal of Administrative Law \& Practice 23: 93-113.

Townshend, H.W. Roger. 2017. "What Changes Did Grassy Narrows First Nation Make to Federalism and Other Doctrines?" Canadian Bar Review 95: 459-88.

Tsilhqot'in Nation v. British Columbia. 2014 [2014] 2 SCR 257. Supreme Court of Canada.

Tzimas, E. Ria. 2011. “To What End the Dialogue?” Supreme Court Law Review 54: 493-527.

Walters, Mark D. 1999. "The Golden Thread of Continuity: Aboriginal Customs at Common Law and Under the Constitution Act, 1982.” McGill Law Journal 44 (3): 711-52.

Young, Joan M., Jason J. Annibale, and Brent Ryan. 2014. “Court Affirms Right of Province to 'Take up' Treaty Lands - Grassy Narrows First Nation v. Ontario (Natural Resources).” McMillan LLP. 


\section{Chapter 6: Implementing Consultation Policy in Ontario and the Federal Leadership Role}

Through the selection of caselaw examined in this dissertation, and other similar cases too numerous to mention, the Supreme Court of Canada has reaffirmed Section 35 as a tool for the reconciliation of settler and Indigenous interests. The duty to consult and accommodate, as described by the Court, is an outgrowth of the honour of the Crown. That duty of honourable dealing applies to all the Crown's relationships with Indigenous peoples, whether on matters relating to recognized or asserted rights, and modern or historic treaties. The Crown represents neither the provincial or federal government in isolation, but rather the source of political authority itself in settler law. The honour of the Crown is therefore important to all Canadians, because it speaks to the trustworthiness of the state itself.

This chapter examines the presence of legal discourse on the duty to consult and accommodate in Ontario legislation and policy guidelines. Depending on how that duty is articulated, conclusions can be drawn about whether the duty has been adopted by the provincial government in a strict and legalistic sense; or whether there are efforts to weave the duty to consult and accommodate in with the Crown's duty of honourable dealing in all CrownIndigenous relations. As has been argued in the preceding chapters, the latter definition, in my view, is how the Supreme Court has bridged Indigenous understandings into the common law.

Much as the 1990 Oka Crisis triggered a critical re-examination of the federal CrownIndigenous relationship through the RCAP, the 1995 standoff at Ipperwash Provincial Park triggered a similar re-examination in Ontario. The recommendations of the 2007 Ipperwash Inquiry continue to inform provincial policy today, and so this chapter begins with a review of those events. Provincial legislation and policy guidelines will then be sampled and analyzed for its framing of the duty to consult, with particular attention paid to land and resource portfolios 
where the issue of sharing land between peoples is most acutely felt. These include energy, the environment, and mining and forestry. Following that, this chapter explores implementation through interviews with Ontario public servants and First Nations representatives who are actively engaged in the work of consultation. The lessons drawn from their experience inform the overall conclusions of this chapter and this research more generally. The closing sections of this chapter compare Ontario’s approach to consultation with certain other provinces and territories, and federal leadership in honourable dealing will be scrutinized. Though the main focus of this research remains the Ontario provincial government, these brief comparative sections will help place Ontario in a broader federal context.

Overall, I conclude that judicial discourse on the duty to consult and accommodate is clearly present in provincial legislation and policy, although discourse on the inherent nature of Aboriginal rights seems limited. Nevertheless, there is ample room in existing law and policy for governments to pursue reconciled Crown-Indigenous relationships built on mutual recognition, respect, responsibility, and sharing. Therefore, the issue I find is less one of policy than implementation.

The interviews and policy analysis presented herein show that current consultation guidelines offered to provincial line ministries are too high-level and vague for consistent implementation by frontline staff. More sector-specific guidelines are needed so that public servants don't repeat colonial patterns through ignorance. Ontario's Indigenous people must be involved in crafting those guidelines if the provincial government is ever to break the cycle of unilateralism. The system of consultations in Ontario is also highly decentralized and lacks oversight, which creates duplicate processes, strains resources both in government and First Nation communities, and hinders the ability of the Province to act cohesively as one Crown. 
Finally, vesting Indigenous rights assessments in government ministries often leads to sharp distinctions between "rights-based" consultation and "interest-based" engagement. Leaving Indigenous communities out of this process means that there may be negative impacts to Indigenous rights before the duty to consult and accommodate is formally triggered.

Systemic change to the Crown-Indigenous relationship may have advanced considerably in law, but it is still in its infancy when it comes to implementation.

\section{A. Lessons from Ipperwash}

In 1942, the federal government expropriated reserve land near Sarnia, Ontario, belonging to the Chippewas of the Kettle and Stony Point First Nation for the purpose of building a military camp. This was billed as a temporary measure for the war effort, and the government committed to return the land after the cessation of hostilities. Yet after the Second World War ended, Ottawa handed most of the land not to the First Nation, but to the Province of Ontario, whereupon it was redrawn as a provincial park. The portion of the reserve containing the military barracks themselves was kept by the Department of National Defence as a cadet camp. The First Nation issued several appeals to National Defence in the intervening decades, recruiting other federal departments to argue their cause. This included a 1947 appeal from the Department of National Heath and Welfare to protect First Nation gravesites located in the camp, and a 1972 appeal from then Minister of Indian Affairs Jean Chrétien to return the reserve lands. (Government of Ontario 2007, 9) National Defence, and indeed the Province of Ontario, repeatedly ignored these requests. By the early 1990s, the land dispute finally came to a head.

In 1993, families from the Kettle and Stony Point First Nation staged a protest by occupying the barracks of the now abandoned military camp. The protest escalated when in 1995 
community members occupied the adjoining parklands, leading to a showdown with Ontario Provincial Police. When then Premier of Ontario, Mike Harris, ordered the police to march on the protesters, an unarmed, 38 year-old community member, Anthony "Dudley" George, was shot and killed by police. (Dubinski 2020)

Following a change in provincial government in 2003, Liberal Premier Dalton McGuinty called a public inquiry into the killing. The Commission delivered its four-volume report in 2007. Most of the recommendations related to police conduct with First Nations, but many of the lessons remain relevant to the Crown-Indigenous relationship more generally. Central to both the report, and indeed the protest itself, was the issue of land. As stated by the Commissioner, Sidney B. Linden:

The immediate catalyst for most major occupations and protests is a dispute over a land claim, a burial site, resource development, or harvesting, hunting, and fishing rights. The fundamental conflict, however, is usually about land. Contemporary Aboriginal occupations and protests should therefore be seen as part of the centuries-old tension between Aboriginal peoples and non-Aboriginal peoples over the control, use, and ownership of land. The frequency of occupations and protests in Ontario and Canada is a symptom, if not the result, of our collective and continuing inability to resolve these tensions consistently. $[\ldots]$

First Nations people regarded and continue to regard the lands they agreed to share as their "traditional lands." The resources on those lands had for many years provided their sustenance. Although they agreed to give up their exclusive Aboriginal title to these lands in making treaties with the Crown, they never intended to abandon them. They continue to regard these lands as a major source of their sustenance and as fundamental to their identity. (Government of Ontario 2007, 79, 83)

Commissioner Linden also argued that resolving most land claims would necessarily

implicate both provincial and federal orders of government. (Government of Ontario 2007, 82)

Duty to consult jurisprudence was still relatively recent at the time of the Ipperwash inquiry, with the Haida Nation, Taku River, and Mikisew Cree decisions all rendered while the inquiry was 
still ongoing. Nevertheless, the report drew specific attention to the duty, and its application to

both recognized Aboriginal rights and asserted rights in a provincial context:

The duty to consult and accommodate $[\ldots]$ offers the real prospect of reconciling Aboriginal rights and interests in land, water, and resources through peaceful, meaningful consultation with Aboriginal peoples and through their participation in decision-making. If properly and effectively fulfilled, the duty to consult and accommodate thus offers the very real potential to significantly reduce the number of Aboriginal occupations and protests.

In my view, developing a provincial policy on the duty to consult and accommodate would be a good place to start to fulfill the obligation. Ultimately, it would be advisable to incorporate an acknowledgement of the duty to consult and accommodate in legislation, regulations, and other applicable government policies. First Nation and Métis organizations should be fully involved in developing these policies.

In addition to this initiative, the provincial government should continue to work with Aboriginal organizations in Ontario to develop co-management arrangements and resource-sharing initiatives and should provide financial or other support to Aboriginal organizations and third parties to develop capacity, identify best practices, and formulate strategies to promote co-management and resource sharing. (Government of Ontario 2007, 84)

The report also recommended the establishment of an independent Treaty Commission of Ontario, which would be inaugurated through ceremony recalling the 1764 Treaty of Niagara.

The Treaty Commission would have a four-part mandate: (1) to assist First Nations and the provincial government in negotiating land claims settlements, (2) develop benchmarks for the settlement of claims, (3) make the claims process transparent to the public, and (4) undertake broad public education on treaties, the treaty relationship, and the claims process for both school curriculum and professional education. (Government of Ontario 2007, 82, 85, 99-100) Though similar Treaty Commissions have already been established in Manitoba, Saskatchewan, and British Columbia, as of writing - and 14 years after the report's recommendation - there is still no independent Treaty Commission of Ontario. (Narine 2020) 
With that said, some of the report's recommendations have been implemented. For instance, Ontario established a distinct Ministry of Aboriginal Affairs (now called Indigenous Affairs Ontario, or IAO) with its own mandate and budget. The report also recommended a fund called the "Ontario Aboriginal Reconciliation Fund" to assist First Nations in maintaining the capacity to consistently engage with provincial officials. Ontario currently manages a "New Relationship Fund", though as will be seen later in this chapter, its mandate differs somewhat from what was contemplated in the Ipperwash inquiry. (Government of Ontario 2007, 86; “Ontario Commemorates 25th Anniversary of Ipperwash Park Tragedy” 2020)

In 2015, twenty years after the killing of Dudley George, the federal government reached a settlement with the Kettle and Stony Point First Nation, providing \$20 million in compensation to Band members, and a $\$ 70$ million trust fund for the development of reserve lands. The former military camp, covering some 890 hectares, was returned to the First Nation, (Burrows 2015) but the work of clearing old, unexploded ordinance from the site remains ongoing. (Dubinski 2020)

A further five years later, Ontario announced the addition of 46 hectares to the First Nation comprising the former Ipperwash Provincial Park. ("Ontario Commemorates 25th Anniversary of Ipperwash Park Tragedy" 2020; "Canada, Ontario, and Chippewas of Kettle \& Stony Point First Nation Announce Addition of Lands to Their Reserve" 2020; Lysyk 2020, 11) While both additions to reserve lands are positive and long-overdue moves by settler government, the provincial process could have taken place years earlier, and is a good example of the privileged position in which settler governments find themselves.

Following the Ipperwash report, Ontario Parks set about reversing the WWII-era expropriation by transferring the land to the federal Ministry of Indigenous Affairs so it could be drawn up as an addition to reserve. (see Appendix C, Chart III) This required a round of 
environmental assessment and, crucially, a value estimate for the land being returned to Ottawa. This process was effectively complete by 2009 , but sat dormant for ten years until internal pressure freed up the necessary funds to cover the administrative cost of land assessment and transfer. ((former) Policy Advisor, Ontario Ministry of Natural Resources and Forestry, in conversation with the author 2020) In my opinion, this anecdote illustrates a key point which we will return to below - that acts of either apathy or simple oversight by civil servants has profound effects on First Nation communities whose lands are being affected. It is a fundamental act of privilege to simply ignore the exercise of Indigenous rights because it is administratively inconvenient to do so, and prolongs colonial power relations. Government staff must always be aware of the effect of their decisions, and regular consultation with Indigenous rights-holders ought to clarify these effects.

\section{B. The Duty to Consult in Ontario Legislation}

In the years following the Ipperwash inquiry, the Ontario government introduced a few key changes to provincial legislation. Significant among these were a series of amendments in 2009 to the 1990 Mining Act. The overall purpose of the Act was changed so that the development of mineral resources would be done "in a manner consistent with the recognition and affirmation of existing Aboriginal and treaty rights in section 35 of the Constitution Act, 1982, including the duty to consult" (Government of Ontario 2009a, sec. 2; see also Hunter, Sahni, and McKibbon 2012,2-3) Section 78 of the amended Act also requires that any mining claim, lease, license or exploration permit be subject to prior Indigenous consultation.

(Government of Ontario 2009a, sec. 78.2.1, 78.3.2.b) Sections 35(2) and 51(4) of the amended Act also allow for restrictions upon the sale or lease of subsurface rights and upon surface rights where portions of a mining claim are deemed as "sites of Aboriginal cultural significance". 
(Government of Ontario 2009a, secs. 14, 29) However, these are all discretionary powers of the Minister, and the good faith implementation of the Act hinges on the reaffirmation of Section 35 rights and the commitment to the duty to consult in the opening sections.

Section 2 of the 2009 Green Energy Act contained an almost identical passage on interpretive consistency with Section 35 rights and the duty to consult. However, the Act was repealed in 2019 under the administration of Premier Doug Ford. (Government of Ontario 2009b) Similar legislation exists in other areas of Ontario energy law, but as might be expected, legislation enacted before the trilogy of Haida Nation, Taku River, and Mikisew Cree were less committal on the subject of Indigenous consultation. Enacted in the wake of the Delgamuukw decision which introduced the possible existence of a duty to consult, the 1998 Electricity Act states that "a long-term energy may include goals and objectives respecting, $[\ldots]$ consultation with aboriginal $[\mathrm{sic}]$ peoples and their participation in the energy sector" (Government of Ontario 1998, sec. 25.29.2.f) While this rather noncommittal passage remains in effect, stronger language was introduced in 2016 amendments, including that the Minister "shall, before issuing a long-term energy plan under subsection (1), consult with any $[\ldots]$ aboriginal peoples $[\ldots]$ that the Minister considers appropriate given the matters being addressed by the long-term energy plan, and the Minister shall consider the results of such consultation in developing the long-term energy plan." (Government of Ontario 1998, sec. 25.29.4) While the amended Act still preserves much of the same ministerial discretion found in the Mining Act, it binds the Minister (i.e. "the Minister shall...") both to Indigenous consultation and the demonstrable consideration of that consultation prior to developing a long-term energy plan.

The 2010 Far North Act is a land-use statute passed with the intention of developing large regions of the province's north by partnering and sharing revenues with Indigenous people, 
as well as instituting protections for some $50 \%$ of Ontario's boreal forest. The area covered by the Act comprises some $42 \%$ of the province, and $90 \%$ of those who live in the area are Indigenous. Although community-based land use plans are considered under the Act, final landuse decisions are left to ministerial discretion, much like previous legislation. (Government of Ontario 2010; Hunter, Sahni, and McKibbon 2012, 3-4; Scott 2019) The Nishnawbe Aski Nation, which represents Treaty 9 First Nations, strongly objected to the Ministry's assertion of unilateral jurisdiction on treaty lands. NAN's position is echoed by Scott and Cutfeet, who argue that "Any new regime for land-use planning in the far north is going to necessarily entail genuine joint-decision-making in which final authority is shared." (Scott and Cutfeet 2019) As will be further discussed in the following section, the Far North Act remains a subject of controversy for both settler and Indigenous governments. The former, now under a new administration, views the Act as needless red tape in northern mining development; and the latter sees the Act as a denial of their inherent jurisdiction over treaty lands.

In contrast to laws which preceded it, the 2017 Child, Youth, and Family Services Act was drafted after comprehensive engagement with Indigenous governments (Benedict 2020), and underscores the fact that the Crown's duty to consult and accommodate affects not just land and resource ministries, but also provincial services. Sections 72 and 73 state that any person or entity providing services under the Act with respect to Indigenous children and youth generally, or a specific Indigenous child, must consult with the relevant community or a communityappointed representative. (Government of Ontario 2017a, secs. 72-73) Section 109(7) states that at least 10 days' notice of an Indigenous child's removal from foster care must be given to their community-appointed representative, and that there must be consultation with that representative on the child's care plan, (Government of Ontario 2017a, sec. 109.7.b) Section 192(2) requires 
identical measures for a child's removal from an adoptive parent or the refusal of an adoption application. (Government of Ontario 2017a, sec. 192.2.c)

Given that Indigenous consultation was incorporated into the drafting of the Child, Youth and Family Services Act, it is perhaps no surprise that its provisions are also significantly more collaborative than land-use legislation. Despite the Province's jealous guarding of ministerial discretion, there is evidence all the same that the duty to consult and accommodate repeatedly features in Ontario provincial law. This is enough to say that the duty to consult and accommodate has the force of law in legislation as well as jurisprudence. The following section examines whether judicial discourse on the duty to consult is also apparent in Ontario's policy guidelines.

\section{The Duty to Consult in Ontario Policy}

As discussed in Chapter 4 of this dissertation, the duty to consult first appeared in Delgamuukw v. BC (1997) in reference to rights recognized under treaty, but prior to Haida Nation in 2004, the duty had little definition and little application outside of treaty rights. Ontario policy from that era also reflects this lack of legal definition. In September 2003, the outgoing Progressive Conservative government in Ontario reached an agreement with the Anishinabek Nation (then known as the Union of Ontario Indians) to create a joint roundtable on natural resource management called the Anishinabek/Ontario Resource Management Council (A/ORMC). The agreement itself sets out the terms of consultation between the parties, but there is scant reference to the duty to consult as a legal duty outside the confines of the agreement:

The A/ORMC recognize that the courts are defining legal duties and responsibilities to consult, however these are open to interpretation and are continually evolving. As a result, the parties have determined the need to develop a practical guide to outline how MNR [Ministry of Natural Resources] and 
Anishinabek First Nation communities can provide, receive, review and comment on information. [...] It is important to acknowledge that these guidelines are available only as a tool to assist in working towards meaningful consultation. The A/ORMC recognize that Anishinabek First Nation communities and MNR may choose to develop or use their own consultation mechanisms. (Anishinabek/Ontario Resource Management Council 2003, 2)

The 2003 agreement serves as a reminder that although the period under investigation in this research is dominated by Liberal party government in Ontario, the commitments to consultation span administrations, and reflect the covenantal nature of the Crown-Indigenous relationship. The agreement defined "meaningful consultation" as "A clear intent by both parties to engage in flexible discussions where the outcome of a particular issue is not presupposed." (Anishinabek/Ontario Resource Management Council 2003, 11; see also Ariss, Fraser, and Somani 2017, 10) Effectively, this amounts to the good faith consultation as described by the Supreme Court in Haida the following year.

In early 2005, following a change in provincial government and the decisions in Haida and Taku River, the Province released a document entitled Ontario's New Approach to Aboriginal Affairs. Most of the document outlined new program commitments to Indigenous communities in the province, but, crucially, it contained inclusive language on the Province's duty to consult and accommodate which closely reflects judicial discourse, as well as Indigenous calls for consistency across government:

Ontario has a duty to consult Aboriginal peoples where its actions may adversely affect an established or asserted Aboriginal or treaty right. The Supreme Court of Canada continues to clarify the nature of this duty.

Ontario is committed to meeting its duty to consult with and, where appropriate, to accommodate Aboriginal peoples. Aboriginal leaders have asked Ontario to adopt a more consistent, effective approach to consultation on matters related to Aboriginal and treaty rights. ("Ontario's New Approach to Aboriginal Affairs" 2005, 15 emphasis added) 
The 2005 policy was followed in 2013 with an information document devoted to Ontario's duty to consult. Although the commitment to the duty to consult and accommodate remained much the same as in 2005, the 2013 document grounded the duty in both the honour of the Crown and Section 35, and removed language concerning ongoing Court clarification of the duty, which suggests a settled understanding of what the duty entails. ("Duty to Consult with Aboriginal Peoples in Ontario: Information on Ontario's Duty to Consult Aboriginal Peoples" 2013) The 2013 document also referred to ongoing engagement as part of a review of consultation policies. In a section entitled "Themes so far," the document pulled 3 key messages from this review: (1) "the importance of strong relationships," (2) "the need for appropriate tools and capacity support for Aboriginal communities and proponents," and (3) "the need for more clarity, transparency and consistency in consultation processes" ("Duty to Consult with Aboriginal Peoples in Ontario: Information on Ontario's Duty to Consult Aboriginal Peoples" 2013) These issues would prove to be recurring hurdles in Ontario's implementation of the duty to consult.

In 2015 the Ministry of Indigenous Relations and Reconciliation (now the Ministry of Indigenous Affairs) released draft guidelines for ministries on the duty to consult and accommodate, guidelines which, as of writing, are still in effect ${ }^{27}$ while final guidelines are in development. The policy echoes judicial dialogue by quoting directly from duty to consult jurisprudence. The guidelines sample passages from Taku River on the Crown's duty of honourable dealing in all relations with Aboriginal peoples, and that this honour "cannot be interpreted narrowly or technically", (Taku River Tlingit First Nation v. British Columbia (Project Assessment Director) 2004, para. 24) as well as from Mikisew on the principle of

\footnotetext{
${ }^{27}$ Manager, Ontario Ministry of Natural Resources and Forestry, email message to the author, October 162020 ; Manager, Ontario Ministry of Environment, Conservation and Parks, email message to the author, November 13 2020
} 
advance consultation being a matter of "broad general importance to the relations between Aboriginal and non-Aboriginal peoples" (Mikisew Cree First Nation v. Canada (Minister of Canadian Heritage) 2005, para. 3; "Draft Guidelines for Ministries on Consultation with Aboriginal Peoples Related to Aboriginal Rights and Treaty Rights” 2015) The guidelines also make use of legal language associated with duty to consult jurisprudence such as "good faith" in meaningful consultation, and "responsiveness" as a requirement of accommodation when "taking up" lands. Following Court guidance in Delgamuukw, the guidelines also allow for the inclusion of oral promises in the establishment of treaty rights. ("Draft Guidelines for Ministries on Consultation with Aboriginal Peoples Related to Aboriginal Rights and Treaty Rights” 2015)

Moving beyond the legally-focussed language of previous consultation guides, the draft guidelines also contain more relationship-focused language, stating that Ontario is "committed to acting in a spirit of mutual respect and fairness, and to achieve an effective approach to consultation that will move Ontario and Aboriginal peoples toward a new era of cooperation and partnership." ("Draft Guidelines for Ministries on Consultation with Aboriginal Peoples Related to Aboriginal Rights and Treaty Rights” 2015)

These are all important steps in aligning the Province's consultation policies with the constitutional law surrounding the duty to consult and accommodate, yet there are a few important caveats. First and foremost is the fact that, ironically, the Ministry of Indigenous Affairs did not engage with Indigenous communities in developing the 2015 consultation guidelines. (Lysyk 2020, 2, 28) This is reflected in the document's framing of Indigenous rights. When defining the nature of Aboriginal rights, the guidelines make use of the Van Der Peet "integral to the distinctive culture" test, which grounds rights in historic practice rather than the more expansive requirements of modern self-government. (for discussion, see Borrows 1997; 
2017) As stated in the guidelines: "the current practice, custom or tradition must have continuity with the historic practice, custom or tradition, and it must remain integral to the community's culture. Present-day activities may be the modern form of a historical practice, custom or tradition." ("Draft Guidelines for Ministries on Consultation with Aboriginal Peoples Related to Aboriginal Rights and Treaty Rights" 2015) In accordance with Haida, the guidelines apply the duty of accommodation to both established (i.e. recognized) and asserted Aboriginal rights, but the framing of the latter is quite limited: "The Crown may be required to take steps to accommodate an established or asserted Aboriginal or treaty in cases where [...] a strong case exists for an asserted Aboriginal or treaty right, and a proposed government action or decision may adversely affect this rights in a significant way. ("Draft Guidelines for Ministries on Consultation with Aboriginal Peoples Related to Aboriginal Rights and Treaty Rights” 2015 emphasis added) If the affected Indigenous communities were involved in determining the significance of rights impacts, then this passage would be relatively unproblematic. Howeveras is common to most Crowns-in-Right in Canada - the assessment of the strength of a claim, the significance of impacts, the scope of consultation, and the extent of accommodation rests with the relevant Minister. Neither of the historical grounding of Aboriginal rights nor unilateral rights assessment is consistent with Aboriginal rights as inherent rights.

The guidelines contemplate funding consultation capacity in Indigenous communities on "larger projects", but commits to no widespread funding, choosing rather to consider requests on a case-by-case basis. ("Draft Guidelines for Ministries on Consultation with Aboriginal Peoples Related to Aboriginal Rights and Treaty Rights" 2015) Most such capacity funding is available by application to the Province's New Relationship Fund, (Director, Ontario Ministry of Indigenous Affairs, in conversation with the author 2018b) but this pot of funding is also used 
for Indigenous business partnerships and Indigenous economic development. ("Funding for Indigenous Economic Development" 2014) Since 2018, the New Relationship Fund has also been administered through the Ontario Grants Program, which means that Indigenous communities must compete for the awarding of a grant. (Kapyrka 2021)

Unfortunately, consultation policy gets relatively little mention in the political mandate of the Ministry of Indigenous Affairs. The most recent mandate latter available is that given in 2016 by Liberal Premier Kathleen Wynne to then Minister, David Zimmer. Most of the mandate letter delves into the specifics of policy programs within the Ministry, and the duty to consult is only mentioned twice: once in reference to federal cooperation on the duty to consult, and second as a commitment to "exploring options to enhance the current consultation processes." (Government of Ontario 2016b) As of writing, the 2018 mandate letters distributed by Progressive Conservative Premier, Doug Ford, have not been publicly released. (CBC News 2019) In the wake of the Truth and Reconciliation Commission report, Ontario released The Journey Together: Ontario's Commitment to Reconciliation with Indigenous Peoples in 2016. The document outlined a series of program commitments valued at some $\$ 250$ million over three years, with the aim of mitigating racism, funding treaty education, supporting Indigenous languages, and closing socio-economic gaps. ("The Journey Together: Ontario's Commitment to Reconciliation with Indigenous Peoples”2016; Ministry of Indigenous Relations and Reconciliation 2017) While this investment in Ontario's Indigenous communities is unquestionably a positive step, more program spending does nothing to address the basis of the Crown-Indigenous relationship itself, given that co-development and co-management is not accounted for in implementation. Apart from a commitment to "consider how to advance resource benefit-sharing opportunities," (“The Journey Together: Ontario's Commitment to 
Reconciliation with Indigenous Peoples" 2016) there is little in the document to indicate a change in Ontario's approach to relationship-building. If anything, the expansion of Indigenous programming across ministry mandates only compounds the Province's already decentralized approach.

Both the 2005 policy and the 2013 information document discussed above mentioned the need for consistency in consultation across ministries, and the 2015 draft guidelines continued to highlight similar issues: "coordination is required across ministries at various levels - for example, senior management, policy, operations, legal services and communications". Indigenous Affairs urges other line ministries to "use the guidelines when developing specific consultation processes within their mandates," while also preserving the flexibility to "assess each situation on its particular circumstances." ("Draft Guidelines for Ministries on Consultation with Aboriginal Peoples Related to Aboriginal Rights and Treaty Rights" 2015) Consistency, coordination, and sector-specific adaptation continues to plague the implementation of the Province's duty to consult and accommodate. These issues were highlighted by the interviewees consulted in this research, as well as more recently by the Auditor General of Ontario.

In December 2020, the Auditor General published a scathing report on the Ministry of Indigenous Affairs. The report highlights many of the issues raised in this dissertation, including that decentralized consultation policy has led to inconsistent, uncoordinated, and unaccountable engagement processes; and that information on Indigenous policy is not sufficiently shared within government, let alone with Indigenous communities themselves. By contacting individual line ministries as well as the Treasury Board Secretariat, the Auditor General compiled for the first time a comprehensive list of all provincially run Indigenous programs and services, amounting in 2019-2020 to $\$ 1.1$ billion in Indigenous-focused spending across 140 different 
programs. At the time of audit, the Ministry of Indigenous Affairs listed only 11 of these 140 programs on its website, and when asked to produce a comprehensive list, could only include 30 , accounting for $\$ 351$ million of the overall $\$ 1.1$ billion in spending. ${ }^{28}$ (Lysyk 2020, 2, 27) The Ministry also does not keep performance measures to assess the effectiveness of these programs. (Lysyk 2020,3)

The report traces some policy problems to the mandate of the Ministry itself. The Ministry is not empowered to take the lead in developing a government-wide vision for Indigenous policy (as in $\mathrm{BC}$ and Manitoba, for instance), but merely to "promote coordination and collaboration." (Lysyk 2020, 24) As it stands, each line ministry decides independently upon the adequacy of consultation. If Indigenous Affairs is not afforded a greater mandate for oversight, coordination and collaboration becomes difficult. The Ministry may advise, but cannot enforce its position on consultation policy, which has important legal implications. The Auditor General remarked that should a lack of consultation result in litigation, one ministry might have knowledge of an Aboriginal rights claim where another ministry does not. As such, the courts would likely find that the Crown had knowledge of the claim, and its failure to share this information resulted in a failure to meet its duty to consult. (Lysyk 2020, 37; see also Dorries 2012, 168; Ariss, Fraser, and Somani 2017, 18) As Dorries succinctly argues: "The ability of the

\footnotetext{
${ }^{28} \mathrm{It}$ is also worth noting that relatively little of overall spending is managed by land and resource ministries who are arguably most implicated in the duty to consult and accommodate. It is not unusual that most government spending will be allotted for services much as health and education, but in the case of Indigenous-focused spending in 2019-20, the Auditor General found $\$ 377.7$ million spent of health and mental health programs, \$228.6 million on education and child care, $\$ 167.5$ million on child and family services, and \$124.9 million on justice initiatives. (Lysyk 2020,14) In total, this amounts to $\$ 898.7$ million out of $\$ 1.1$ billion in spending. This means that all other ministries were managing a pot of $\$ 201.3$ million in that fiscal year. Should similar allocations hold true over several fiscal years, this goes some way to explaining the capacity challenges faced both within the government and with Indigenous partners.
} 
Crown to fulfill its duty to consult and thus maintain the honour of the Crown hinges on the ability [...] to proceed as a unified Crown.” (Dorries 2012, 169)

Both sharing information on Aboriginal and treaty rights and avoiding duplicate consultations could be addressed through technological solutions, but this strategy has shown limited use. The Province conducts thousands of Crown-Indigenous consultations every year across its various ministries, and in 2006 the Ministry of Indigenous Affairs developed a digital system called the Aboriginal Consultation and Information System (ACIS) to share this information with provincial employees. In addition to tracking ongoing consultations, ACIS also contained information on treaty areas, land claims, rights assertions, traditional areas, and briefing documents and backgrounders. The Auditor General found that the system cost $\$ 1.4$ million to set up and cost about \$2.5 million to maintain between 2012 and 2019. However, use of the ACIS system is voluntary, and no ministry, including Indigenous Affairs, has added new information since 2015. Between 2016 and 2019 use of the ACIS system dropped 34\%, with civil servants complaining that the system is not user-friendly and is time-consuming to update. To address these issues, Indigenous Affairs has committed to rolling out a replacement system in March 2021 called the Knowledge Management System (KMS). (Lysyk 2020, 35; see also Dorries 2012, 170) It remains to be seen whether this new system will see more consistent use than the last, and whether this will lead to greater coordination in Crown-Indigenous consultation across ministry mandates.

Lastly, the Auditor General noted that the Province does not report on implementing the recommendations of the 2007 Ipperwash Inquiry. The audit remarks that many of the issues it identified would have been addressed by implementing the Ipperwash recommendations. (Lysyk 2020, 5, 43) As seen above, this included the establishment of an independent Treaty 
Commission of Ontario to monitor and report on land claim and treaty implementation, manage capacity funding for treaty negotiations, and spearhead education on treaty rights. Establishing an independent Treaty Commission would also remove the conflict of interest involved in provincial assessment of Aboriginal rights: the Crown must simultaneously assess the legitimacy of rights claims while also seeking to limit its liability, since it is also the defendant in such claims. (Lysyk 2020, 4, 42)

Given that Ontario's approach to consultation spans ministry mandates, it is worth having a closer look at the approach some individual line ministries take in their duties to Indigenous people. The Ministry of Energy, for instance, tends to manage consultation through its various agencies. In 2007, on the Ontario Energy Board, as the Province's energy regulator, issued a consultation policy in recognition of the fact that land development for energy projects could pose a risk to Aboriginal and treaty rights. Although the policy itself is only two pages long, the Board specifically mentions that the policy is informed by duty to consult jurisprudence, including Haida Nation, Taku River, and Mikisew Cree.(“Aboriginal Consultation Policy” 2007, 1) As for the role of the Board itself, being an agent of the Ontario Crown, the policy confines it to an oversight role for energy projects proponents, responsible for evaluating the adequacy of consultation on a case-by-case basis.("Aboriginal Consultation Policy" 2007, 2) While this approach limits partnership with Indigenous communities affected by energy projects, it is likely appropriate for the Board's mandate as a regulatory body. The capacity for partnership ought to be developed within the broader mandate of the Ministry of Energy itself.

Another arms-length agency of the Ministry of Energy, the Independent Electricity System Operator (IESO), which oversees the day-to-day operation of Ontario's electricity grid, 
also has its own Indigenous consultation protocols. IESO consultations relate largely to service delivery issues faced by Indigenous communities rather than the land use planning contemplated in other line ministries. This generally means that power-sharing arrangements are not on the table, so negotiations are lower stakes for the Province. Nevertheless, IESO consultations are a model of good faith engagement that ought to garner attention from other ministries.

For starters, the IESO independently provides support to Indigenous communities to support their engagement capacity. (“Corporate Indigenous Policy” 2020, sec. 3.1.4; (former) Acting Manager, Ontario Ministry of Energy, in conversation with the author 2018) IESO consultation policy is also revised at regular intervals in collaboration with Indigenous partners. The current policy commits to updates at least every 3 years. ("Corporate Indigenous Policy" 2020, sec. 3.1.7) In 2018, the IESO published a report in the wake of the Province's 2017 LongTerm Energy Plan. The report provided recommendations on conservation and program access which responded to the unique challenges of delivering services to Indigenous communities. It is held up as a model here simply due to the open-endedness of discussion and the thoroughness of Indigenous engagement in its creation. This included regional meetings and symposia, community visits, engagement with Provincial Territorial Organizations such as the NishnawbeAski Nation and the Métis Nation of Ontario, webinars, and the IESO's own internal roundtable, the Aboriginal Energy Working Group. ("Indigenous Conservation Programming: A New Approach - Report on Energy Conservation for First Nations and Métis in Ontario" 2018,2) The report was issued in response to instruction from then Minister of Energy Deb Matthews, (“Indigenous Conservation Programming: A New Approach - Report on Energy Conservation for First Nations and Métis in Ontario" 2018,2) using ministerial powers under the Electricity Act. (Government of Ontario 1998, secs. 7-8) While the report itself is a good example of 
Crown-Indigenous consultation, it is unclear whether such processes are sufficiently wellestablish to persist without specific direction from Cabinet. The report also highlighted consistent issues in Indigenous relations with the province, including:

[...the] absence of a coordinated and holistic approach at the federal and provincial levels of government; [the] lack of information about funding sources, including First Nations' eligibility to access existing funding sources; [and the] lack of flexibility in terms of delivery timetables and performance criteria in existing programs. ("Indigenous Conservation Programming: A New Approach Report on Energy Conservation for First Nations and Métis in Ontario" 2018, 4)

As for the 2017 Long-Term Energy Plan itself, there are only two direct references to the duty to consult and accommodate in its 150 pages, first as a reaffirmation of the Province's commitment to fulfilling the duty, and second as an obligation for project proponents.

(“Ontario's Long-Term Energy Plan 2017: Delivering Fairness and Choice” 2017, 124, 146)

However, the discussion guide released alongside the plan contains broader language around the Crown-Indigenous relationship, making reference to the 2015 Political Accord between the Province and the Chiefs of Ontario, and leaving the door open to the negotiation of selfgovernment:

In August 2015, the Chiefs of Ontario signed a historic Political Accord with the Government of Ontario. This Accord guides the relationship between First Nations and the province. The government is committed to working on a range of issues, including jurisdictional matters and the sharing of resource benefits. The Accord is in line with the spirit and intent of the Calls to Action issued by the Truth and Reconciliation Commission and the United Nations Declaration on the Rights of Indigenous Peoples. ("Changes on the Horizon: 2017 Long-Term Energy Plan Discussion Guide” 2017)

The opening text of that Accord leaves no doubt about the inherent nature Indigenous governance rights:

First Nations have an inherent right to self-government and that the relationship between Ontario and the First Nations must be based upon respect for this right. An inherent right to self-government may be given legal effect by specific rights recognized and affirmed by section 35 of the Constitution Act, 1982, or through 
negotiated agreements and legislation ("Political Accord Between First Nations and the Government of Ontario" 2015)

Also in 2015, Ontario began the process of partially privatizing Hydro One, the agency responsible for electricity transmission infrastructure and distribution services. In January 2018, the Province announced that it had sold nearly 14.4 million shares in the company, valued at \$260 million, to the Chiefs of Ontario, meaning that the shares are commonly owned by the organization's 133 member First Nations. While this represents only $2.4 \%$ of shares compared to the Province of Ontario's 47.4\%, the sale nevertheless guarantees Ontario First Nations a seat at the table, and a role in deciding how electricity infrastructure and distribution affects their communities. It is still too early to properly assess how the Chiefs of Ontario will distribute the shares or how rights-holding communities will choose to use them, as the deal prevents their sale for five years, (Rice 2018) carrying any financial planning on the matter into 2023 at the earliest.

In Ontario's Environmental Assessment process, the Government's 2014 Code of Practice sends some mixed messages about Indigenous consultation. On the one hand, the code contains broad and inclusive language around the initiation of consultation: "Consultation with potentially affected Aboriginal communities is required. Proponents should prepare a list of Aboriginal communities that are potentially affected by or interested in an undertaking." ("Consultation in Ontario's Environmental Assessment Process" 2014, sec. 3.1.2) On the other hand, the code continues to protect the unilateral decision-making of the Ministry, (see also “Modernizing Ontario's Environmental Assessment Program" 2019,6) and limits Aboriginal rights to historic cultural practices :

If the proponent of the proposed undertaking is not the Crown and an Aboriginal community has asserted that the Crown has a duty to consult based on the 
potential adverse effect on an Aboriginal or treaty right, then the proponent should notify the Director. The Director will determine what next steps are required.

Aboriginal rights stem from practices, customs or traditions that are integral to the distinctive culture of the Aboriginal community claiming the right. Treaty rights stem from the signing of treaties by Aboriginal peoples with the Crown.

Aboriginal rights and treaty rights are protected by section 35 of the Constitution Act, 1982. (“Consultation in Ontario's Environmental Assessment Process" 2014, sec. 3.1.2)

Similarly, Ontario's consultation guide for Renewable Energy Approvals provides useful information to applicants (that is, energy proponents) on fulfilling their role in the duty to consult. However, the language in the guide can be read as though the duty stems from provincial government regulation rather than inherent rights recognized and affirmed under Section 35:

Aboriginal consultation is a mandatory regulatory requirement for applicants of projects requiring a REA, other than class 2 wind facilities. For the purposes of this guide, Aboriginal communities include First Nation and Métis communities. This guide is intended to stress the importance of applicants engaging the Aboriginal communities about proposed renewable energy projects in ways that will be meaningful and in ways that facilitate effective and timely information exchange.

This guide is designed to complement O. Reg. 359/09 and technical guidance as well as the Ministry of Natural Resource's Approval and Permitting Requirements Document for Renewable Energy Projects. [...] The Aboriginal Consultation Guide for preparing a Renewable Energy Approval (REA) Application supports the development of a complete REA submission under provincial regulations. (“Aboriginal Consultation Guide for Preparing a Renewable Energy Approval (REA)” 2016)

The consultation guide also states that proponents are expected to engage in good faith, but is more vague and non-committal on matters of partnership and co-management: "the applicant[...] may also want to consider the community's other interests in the project" ("Aboriginal Consultation Guide for Preparing a Renewable Energy Approval (REA)”2016) As will be further discussed below, the distinction between "rights-based" consultation and "interest-based" engagement is a common feature in Ontario's approach. 
This equivocal language frequently appears in provincial policy and guidance documents. Words such as "may", "should", "recommend", or "encourage" often qualify passages relating to consultation and engagement. (Kapyrka 2018, sec. 2) This belies the constitutional nature of the duty to consult and accommodate, as noted in a recent paper from the Association of Municipalities of Ontario:

The principle of the honour of the Crown and the duties that flow from it are not vague concepts. They are fundamental to the constitutional make-up of Canada. [...] By seizing the opportunity to clarify how Crown duties are to be implemented in Ontario, the province can address its constitutional obligations in a constructive fashion. In doing so, it will advance the harmonious workings of Ontario's governments - Crown, Indigenous and municipal. (Association of Municipalities of Ontario 2019,6)

This position was echoed in research interviews, as well. As the Consultation Liaison for Curve Lake First Nation noted: "[H]ow can you uphold constitutionally protected rights and then just “encourage" the province or the municipality to engage? It doesn't line up." (Kapyrka 2021)

One example of such discourse is the 2012 consultation policy issued by the Ministry of Northern Development and Mines (MNDM) in response to the 2009 amendments to the Mining Act. The policy firmly grounds the duty to consult in the honour of the Crown, and requires consultation when contemplating actions that might affect Aboriginal and treaty rights recognized under Section 35. (Ontario Ministry of Northern Development and Mines 2012, 2) Notably, the policy does not connect the duty to consult to asserted rights, as described in Haida. When it comes to accommodating Aboriginal rights, the policy is limited to suggesting best practices: "Once projects reach the stage of requiring an exploration permit, MNDM strongly encourages proponent to make efforts, including through the regulated consultation process, to reach arrangements with communities, Those arrangements should, ideally, reflect the following principles..." (Ontario Ministry of Northern Development and Mines 2012, 11 emphasis added) 
Mining proponents are tasked under the policy with sharing project information with identified Indigenous communities and leading community discussions, but MNDM retains the responsibility to identify rights-holding communities, and to oversee and approve consultation. (Ontario Ministry of Northern Development and Mines 2012, 3, 5-6) The policy does not mention whether either consultations or approvals are shared with Indigenous Affairs, underscoring the siloed approach to consultation highlighted by the Auditor General. (Lysyk 2020, 24)

There is also a clear development bias in the 2012 MNDM policy. It acknowledges that there are "differing perspectives" on Indigenous rights to self-government, Indigenous regulation of traditional lands off-reserve, and the resolution of historic grievances; and asserts that Indigenous communities engaged in consultation should "not take unreasonable positions to thwart government from making decisions or in an attempt to prevent projects from proceeding." (Ontario Ministry of Northern Development and Mines 2012,4) This could be interpreted as a call to negotiate in good faith, but fails to mention whether Indigenous perspectives ought to be included in defining a "reasonable" position. MNDM encourages proponents to finance Indigenous consultation capacity, but supports this only indirectly by offering tax credits to proponents for assessment costs. (Ontario Ministry of Northern Development and Mines 2012,9) This arms-length approach to capacity funding not only weakens the connection between Indigenous peoples and the Crown, it may also affect the ability of communities to participate in the consultation process. This is particularly worrying because under the policy, a "[l]ack of response [to an exploration notice] will not prevent a decision by the MNDM." (Ontario Ministry of Northern Development and Mines 2012, 8) 
Even more than mining, perhaps no land and resource ministry in Ontario has more significance for Indigenous traditional territories than the Ministry of Natural Resources and Forestry. (Bellefeuille 2020) As seen above, one of the earliest institutional partnerships between First Nations and the Government of Ontario was established in 2003 for the purpose of natural resource management: the Anishinabek/Ontario Resource Management Council (A/ORMC). Ontario briefly convened another similar policy table in cooperation between the Ministries of Indigenous Affairs, Natural Resources, Northern Development and Mines, and the NishnawbeAski Nation (NAN). The so-called Northern Table lasted from 2007 to 2008, but NAN suspended bilateral talks in solidarity with their member community of Kitchenuhumaykoosib Inninuwug (KI), whose leaders had been arrested for evicting a mining company, Platinex, from their land claim areas after the company began drilling without prior consultation. Though the KI leadership was never criminally charged, the Northern Table was never re-established and Ontario was forced to pay millions of dollars to buy out the contested mining claims. (Canada NewsWire 2008; Scott and Boisselle 2019, 11; Scott and Cutfeet 2019; see also “Ontario's New Approach to Aboriginal Affairs" 2005, 16)

The most recent publicly available report of the A/ORMC dates from 2008. As stated in that report, the Council modeled its own institutional principles based on the 4 Principles of a Renewed Relationship described by RCAP:

The Anishinabek Nation and Ministry of Natural Resources affirm the basic principles of mutual respect, recognition, responsibility and sharing, and aim to build a relationship based on sustainable trust. [...] The Anishinabek Nation and the Ministry of Natural Resources have established a foundation of positive interaction and continue to use good ethics of respect and trust to build relationships. (Anishinabek Nation 2008, 16)

The A/ORMC encompasses a number of issue-specific working groups within its mandate, including enforcement, fisheries, lands, and water. (Anishinabek Nation 2008, 3) In 
March 2016, the Province and the Anishinabek Nation ${ }^{29}$ renewed their commitment to the A/ORMC. ("Ontario and Anishinabek Nation Renew Commitments on Natural Resource Management" 2016) There is no public documentation of the Council's activities since the recommitment, but nevertheless the Council represents a positive, institutionalized commitment to partnership which extends beyond the minimum procedural requirements of consultation. The model of the A/ORMC is a useful example for policymakers, who ought to examine how institutionalized partnership can apply to consultations within their mandates.

Agencies operating under the aegis of the Ministry of Natural Resources and Forestry, however, have more work to do in this area. For example, The Algonquin Forestry Authority, which oversees logging operations within Algonquin Park, does outline commitments to Indigenous rights and co-management within its 2016 Sustainable Forest Management Policy. The policy outlines a series of commitments, including the respect for Aboriginal and treaty rights, and promoting equal participation by Indigenous communities in the benefits of forest management in Algonquin Park. ("Sustainable Forest Management Policy” 2016, sec. 4) Despite these commitments, the outcome of the Forest Authority's management of park lands is open to question. The 2020 report of the Auditor General of Ontario outlined that commercial logging in Algonquin Park id so widespread, that two-thirds of park lands can no longer be considered “protected". (McIntosh 2020c)

\footnotetext{
29 In early 2020, Anishinabek Nation began the process of ratifying the Anishinabek Nation Governance Agreement (ANGA) which would see member First Nations claim jurisdiction over elections, membership law, language and culture, and government operations. More critically, it would transform the Anishinabek Nation from an incorporated provincial-territorial organization to a federally recognized regional government. There is some internal debate over whether the AGNA actually represents a significant change, either in governance or financing, over what member First Nations already had available. (King 2020a; 2020b) As of writing, the outcome of the ratification is not yet known, since the COVID-19 pandemic delayed the voting process by a full year. (see North Bay Nugget 2020; White 2020)
} 
The need for cooperation and co-development has re-emerged particularly in Treaty 9 territory, encompassing the so-called Ring of Fire. This mineral-rich area was earmarked for resource development under the 2010 Far North Act, but Ontario's 2015 Draft Far North Land Use Strategy, created in response the Act, is currently in doubt. As discussed in this chapter's review of provincial legislation, the Act emphasizes the joint preparation of land-use plans in the region, and a Ring of Fire Secretariat was established to coordinate Indigenous consultations, but final land-use decisions remain under the Minister's exclusive purview. (Government of Ontario 2010; MNRF 2015b; Scott 2019) A slide deck presented by Ministry of Natural Resources staff to the 2015 Northern Ontario First Nations' Environmental conference reveals some of the Indigenous feedback on the 2015 draft strategy. First Nations indicated that Ontario should be clear that the draft strategy is a government document and did not come from First Nations, that land-use planning should include more emphasis on traditional knowledge, that more monitoring of ecosystems was needed, and that there should be more detail on implementation. (MNRF 2015a, 9)

Irrespective of the controversy over the draft strategy, it is not clear whether the current Progressive Conservative government will implement it. As of writing the Far North Act remains in effect, but the 2019-20 departmental plan for the Ministry of Indigenous Affairs commits to "working with the Ministry of Natural Resources and Forestry (MNRF) to repeal the Far North Act to reduce red tape and promote economic development for First Nations in the Far North including the Ring of Fire." (Government of Ontario 2019) Of the 50\% of lands in the far north targeted for protection under the Act, the 2020 Auditor General's report found that only $10.4 \%$ is currently protected. (McIntosh 2020c) When and if the Act is repealed, it is not clear what legislative and policy tools will replace it. However, legal scholar Dayna Scott reminds us, "In 
the void left by the repeal of the Far North Act, there is a thriving Indigenous legal order."(Scott 2019)

The current provincial government of Premier Doug Ford has faced much criticism recently on its handling of the Indigenous Affairs portfolio, particularly after a $\% 15$ cut to the department's 2019 budget. (Johnson 2019) In July 2020 the Government passed Bill 197, omnibus legislation aimed at economic recovery from the COVID-19 pandemic which included changes to some 20 pieces of legislation surrounding provincial environmental assessment rules. First Nations in the province immediately faced uncertainty about how these changes might affect land-use planning in their territories. As one research interviewee asked:

$[\mathrm{H}]$ ow do these amendments, how do these changes affect the duty to consult? How do they affect our treaty and Aboriginal rights? And if there's no environmental assessment process, or no permit[ting] process, how then are we even notified as to what's happening on the land?

[R]ight now that's how we're notified if the Province does not notify us directly in advance - it's usually through an EA process. [...] [T] he EA process was at least one mechanism that would alert us even if we weren't involved initially. [...] There're so many regulatory changes coming at us from all directions, from all various ministries that there's only so much you can do. (Kapyrka 2021)

By August, several unnamed First Nations filed suit over the changes featured in the COVID recovery omnibus, a move which was supported by the Chiefs of Ontario. (McIntosh 2020a) Later that same month, three First Nation communities - the Chapleau Cree, Missanabie Cree, and Brunswick House First Nations - filed suit over the Ontario government's failure to properly consult on plans to manage the over 20,000 square-kilometre Gordon Consens Forest in northeastern Ontario. The case is scheduled for hearing in March 2021. (McIntosh 2020b)

Another notable policy change is a recent uptick in the use of so-called Ministerial Zoning Orders (MZOs). This is an emergency power under the Planning Act which permits the 
Minister of Municipal Affairs and Housing to bypass the municipal planning process in approving land development. For example, when the Algo Centre Mall in Elliott Lake collapsed in 2012, destroying the town's only grocery store, an MZO allowed a new store to be built as quickly as possible. However, by the end of August 2020, the Ford government had issued over 33 MZOs - more than all the combined orders issued since 1999. These included 14 orders issued in 2020 for residential development, and another 6 for industrial development. These orders forego any municipal or Indigenous consultation in the planning process, and have occasionally been issued over the explicit objection of local municipalities. (T. Gray 2020; see also Kapyrka 2021)

The Ontario Crown is also in the middle of litigating the three-part case of Restoule $v$. Canada, which is seeking legal clarification of unpaid annuities promised to the First Nation beneficiaries of the 1850 Robinson Huron and Robinson Superior Treaties. Stage one of the case, decided in 2018, concluded that augmentation clauses tied to annuity payments in the Robinson Treaties can be linked to the resource wealth generated from Treaty lands. This is consistent with the interpretation of treaties as ongoing relationships with the Crown. As written by Justice Patricia Hennessy:

The Robinson Treaties of 1850 descended from that Covenant Chain relationship. The Treaties were a renewal of the ongoing relationship between the Anishinaabe and the Crown. The Treaties were not meant to be the last word on the relationship. Renewal of the relationship was necessary to ensure that both parties could continue to thrive in changing environments. (Restoule v. Canada (Attorney General) 2018, para. 422)

In Stage Two of the case, decided in June 2020, the Ontario Crown argued that it was not liable for the payment of past annuities by invoking "Crown immunity", or the Crown's inability to be sued under tort law. (Restoule v. Canada (Attorney General) 2020, para. 28) The First 
Nation plaintiffs argued that Crown immunity does not apply to fiduciary claims under treaty, and Justice Hennessy agreed, citing the sui generis nature of the Crown's fiduciary duties. (Restoule v. Canada (Attorney General) 2020, paras. 11, 40) Justice Hennessy also offered a strong assessment of the duty of honourable dealing owed by the Ontario Crown:

Ontario seems to find some distinction between the interpretation of a treaty, the implementation of the treaty, and the interpretation of a statute, which impacts upon the interpretation or implementation of a treaty, when it comes to the applicable principles of the honour of the Crown. But this distinction is not founded on the jurisprudence. The duty of the honour of the Crown has arisen largely in the treaty context, where the Crown's honour is pledged to diligently carry out its promises. The duty requires that the Crown ensure that its treaty obligations are fulfilled. Time and again, the honour of the Crown duty is imposed on both the interpretation and implementation of treaties and of statutes. (Restoule v. Canada (Attorney General) 2020, para. 232)

The forthcoming Stage Three of the case will determine the quantum of damages owed to Robinson Treaty beneficiaries by the provincial and federal Crowns, based on their respective resource-based revenues and expenses for the last 140 years since annuity payments were stopped. (Restoule v. Canada (Attorney General) 2020, paras. 276, 284)

For all the significant legal hurdles that Ontario is currently facing, it has received some praise from First Nations for its open communication with Indigenous communities during the COVID-19 pandemic. At the height of provincial lockdown, some 70 to 80 Chiefs sat in on weekly conference calls with provincial health representatives. (Laskaris 2020) The Ministry of Indigenous Affairs also coordinated effectively with its line ministry partners to quickly deploy emergency supports to Indigenous communities in the province. The success of this "one window" strategy garnered praise from the Auditor General. (Lysyk 2020, 25) Hopefully this newfound commitment to open communication will last beyond the current pandemic and extend into other policy areas. The following section explores some of those implementation experiences from both public service and First Nation perspectives. 


\section{Interviews on the Implementation of Ontario's Duty to Consult}

Between January 2018 and January 2021, I conducted semi-structured interviews ${ }^{30}$ with Ontario public servants and First Nation representatives to discuss their experience with how Ontario's consultation policies were being implemented. Out of a total of 15 interviews, 9 were public servants representing 5 different provincial ministries, ${ }^{31}$ and 6 were First Nation representatives from 5 different First Nation organizations across Ontario. ${ }^{32}$ Interviewees were all deliberately selected based on the authority vested in their office and the role of their organization in managing consultations between First Nations and the Ontario Crown.

Within the Ontario Public Service, I wanted to speak to staff at the Ministry of Indigenous Affairs, which produces umbrella consultation policies for use by other ministries. I also wanted to discuss mandate-specific consultation practices across a range of line ministries, whether land and resource ministries or service-focused ministries. ${ }^{33}$ The focus of these interviews on implementation meant that most interviewees were mid-level management who carried the responsibility for overseeing consultations, but who were not responsible for the creation of consultation policy.

\footnotetext{
${ }^{30}$ See Appendix B for an overview of interview questions. Being semi-structured interviews, these questions allowed for divergence based on policy context and personal experience.

${ }^{31}$ These 5 ministries were: (1) the Ministry of Indigenous Affairs, (2) the Ministry of Health, (3) The Ministry of Transportation, (4) the Ministry of Energy, and (5) the Ministry of Natural Resources and Forestry. Interviewees ranged in seniority from Policy Advisor to Assistant Deputy Minister, though the majority were Managers and Directors.

32 These 5 organizations were: (1) the Algonquins of Pikwakanagan First Nation, (2) the Anishinabek Nation, (3) the Windigo First Nations Council, (4) the Mohawk Council of Akwesasne, and (5) the Curve Lake First Nation. Interviewees ranged in seniority from Consultation Officer to Grand Chief.

${ }^{33}$ For greater clarity, "land and resource ministries" refers to ministries directly involved in land-use planning and development. Interviewees drawn from such portfolios represented the Ministries of Transportation, Energy, and Natural Resources and Forestry, respectively. "Service-focused ministries" refers to departments whose mandate relates chiefly to the provision of public services without a major land management component. Just one interviewee represented such a portfolio, specifically the Ministry of Health.
} 
On the First Nations side, I wanted to speak to organizations representing a variety of different levels of governance, whether rights-holding First Nation communities or representative bodies organized along close regional ties (e.g. tribal councils) or broader cultural ties (e.g. provincial territorial organizations). I also wanted to speak to leaders drawn from different cultures and treaty areas across Ontario. ${ }^{34}$ First Nation interviewees, whether consultation officers, legal counsel, or elected leaders, all had personal experience consulting with the Ontario Crown.

Across these 15 interviews, certain ideas frequently re-emerged among both civil servants and First Nation representatives. To aid the discursive analysis in this research, I have organized these ideas around five central themes: (1) the decentralized nature of provincial consultations, (2) the repeated distinction between "consultation" and "engagement" with Indigenous communities, (3) the need for sector-specific guidance on consultation and information-sharing between ministries, (4) who discharges the duty to consult, and (5) breaking the cycle of the Crown's unilateral rights assessment.

\footnotetext{
${ }^{34}$ Most of the traditional territory of Ontario First Nations is land belonging to Anishinabek peoples (e.g. Algonquin, Chippewa, Mississauga, Odawa, Ojibwe), and so my First Nation interviewees mostly represent Anishinaabe communities and organizations. Each of these organizations are located in different treaty areas. The Algonquins of Pikwakanagan First Nation are in the process of negotiating a modern treaty covering much of the Ottawa river valley and surrounding territory. This claim area overlaps pre-Confederation treaty areas including the Crawford Purchase (1783), Rideau Purchase (1819), and Robinson-Huron Treaty (1850). The Curve Lake First Nation is located in Williams Treaty territory (1923). The Windigo First Nations Council represents 7 member First Nations in Treaty 9 territory (1906/1930). As of writing, the Anishinabek Nation is not a rights-holder (see in supra 29) but rather a representative organization with 39 member First Nations linked to territories from the Huron Tract Purchase (1833) in the south to the Robinson Superior Treaty (1850) in the northwest. (For a visualization of these treaty areas, visit the Ontario Ministry of Indigenous Affairs at https://www.ontario.ca/page/map-ontariotreaties-and-reserves)

I also interviewed leadership in the Mohawk Council of Akwesasne, one of the largest Haudenosaunee communities (and indeed one of the largest First Nations) in Canada. The relationship between the Haudenosaunee and the Crown is directly linked to the Covenant Chain and the Two-Row Wampum. The relationships contained in these agreements are foundational to Crown-Indigenous treaty relationships writ large. I did not interview representatives from Oji-Cree and Cree communities the Ontario's far north, but these communities are also located in Treaty 9 territory.
} 
The first theme to emerge from these interviews is that Ontario's approach to First Nation consultation is quite decentralized. The Ontario Ministry of Indigenous Affairs (IAO) is responsible for developing the Province's umbrella policy on consultation and helps line ministries identify Indigenous rights-holders and interest groups, but implementing the duty to consult and accommodate is largely left to line ministries, acting in accordance with their particular mandates. ((former) Legal counsel, Ontario Ministry of Indigenous Relations and Reconciliation, in conversation with the author 2018; see also Sterling and Landmann 2009, 3) These diffuse responsibilities for consultation and regulatory approval have proven confusing and burdensome for both provincial and municipal public servants (see Association of Municipalities of Ontario 2019, 3) as well as First Nation partners. A ministry which has the approval authority to sign off on changes to land-use planning is often not the same ministry to issue permits for activities related to land-use changes, which means that First Nations are bounced back and forth between ministries. (Kapyrka 2021; see also 2018, sec. 4) Open communication between ministries could significantly reduce timelines and duplicate consultation. The ongoing challenge for government in this decentralized landscape ${ }^{35}$ is to ensure the consistency of consultation practices across ministries, such that multiple teams are acting as one Crown. (Director, Ontario Ministry of Indigenous Affairs, in conversation with the author 2018a; Bigelow 2018; (former) Legal counsel, Ontario Ministry of Indigenous Relations and Reconciliation, in conversation with the author 2018)

These line ministry teams developed over a period of years in the mid-2000s. Although the Ontario government had been engaging with First Nations on land claim issues since the mid-1980s, (Wedge 2018) there was an expansion of Aboriginal Affairs branches in land and

\footnotetext{
${ }^{35}$ See Appendix D for a visualization of the players involved in Indigenous programs and services in Ontario.
} 
resource ministries after the 2007 Ipperwash report. ((former) Legal counsel, Ontario Ministry of Indigenous Relations and Reconciliation, in conversation with the author 2018; Bellefeuille 2020; Lysyk 2020, 12-13) The last of these branches was established in the Ministry of Transportation in 2011. (Bigelow 2018) Across all ministries, the Government of Ontario issues tens of thousands of authorizations every year across the consultation spectrum, ranging from minor private developments to major public works projects. (Wedge 2018) Individual First Nation communities often receive 5 to 10 notifications every week. (Whetung 2020) Spread over 133 First Nation communities in the province, that represents a major capacity requirement for both the provincial government and First Nations, but generally more so for the latter. As explained by Julie Kapyrka, the Consultation Liaison for Curve Lake First Nation:

[W]e worry about our sister communities that don't have consultation workers, or they [do] have a consultation worker but they are doing three jobs. Consultation is but one of the hats they wear in a community, and it's just not viable to sustain [a] consultation office when you have someone doing three jobs.

$[\ldots]$

[T] he other problem is this "meaningful consultation." I mean, to do it meaningfully we need to come to the table as equal partners, right? [...] $[\mathrm{M}]$ inistries have thousands of workers whereas our "ministry," as I call it, has two. [...] [Many] of these ministries come to the table, and they're meeting with my colleague and I, and there's 15 of them and two of us. They have all their experts, their biologists, their engineers and everything, and we have just the two of us. And while my colleague is well versed in the environmental capacity and I'm [on] the archaeological as well as [the] engagement [...] policy side of it, we don't have that expertise [regarding] stormwater management, or hydro-geology, or nuclear waste, or any of that. [...] [H]ow can we begin a meaningful consultation when we don't even have the expertise needed to understand what's happening? When we ask for capacity funding to be able to hire somebody to help us do that, [often] the government simply says they don't have that funding.

(Kapyrka 2021) 
IAO generally leads Ontario's relationship with the federal government on Indigenous issues, (Bigelow 2018) and the federal government often sets the policy tone for provincial governments, such as the implementation of the United Nations Declaration on the Rights of Indigenous Peoples. ((former) Legal counsel, Ontario Ministry of Indigenous Relations and Reconciliation, in conversation with the author 2018; (former) Policy Advisor, Ontario Ministry of Natural Resources and Forestry, in conversation with the author 2020) The federal government also frequently plays the role of financier, funding both First Nations capacitybuilding and compensation for rights infringement, whereas the provincial government is the principal land management regulator. (Wedge 2018; Administrator, Windigo First Nations Council, in conversation with the author 2020)

IAO has an important coordinating role across provincial line ministries, particularly when facilitating land claim negotiations. As explained by Assistant Deputy Minister, Grant Wedge:

[W]hen we're settling a claim, we're representing the Crown, the Government of Ontario, in a corporate way, but there will be [multiple] interests. We've talked about roads, $[\ldots]$ hydro lines, $[\ldots]$ snowmobile trails, all of which mean that part of our negotiation team is working behind the scenes with those line ministries so that they better understand what it is that we're trying to do and what the reaction is, both from stakeholders and from the First Nations community. (Wedge 2018)

Successful coordination also requires educating line ministry staff on the duty to consult and accommodate and the operational requirements of fulfilling the duty. (Wedge 2018) As former Director Randy Reid explained, that work is still ongoing:

$[\mathrm{O}]$ ne of the roles, from my perspective, [are] the linkages between our other ministries. They, too, have a duty to consult. But they rely upon us, and we advise them in a lot of ways as to how to go about it. And when you talk about issues from the Indigenous community's perspective, sometimes ministries will consult, or felt they have [consulted], but the Indigenous communities themselves will not 
consider what the ministries have done to be consultation. Now, we'll hear that because we're in line with the communities all the time. Like, "these other guys came and they didn't really consult. They said they consult[ed], but it wasn't consultation." So then we'll reach out and talk to the ministries and help facilitate some of that dialogue as well. That's not necessarily a core business of ours, but because of our relationships with the communities, it seems to be something that both the ministries and the communities find helpful.

[...]

I think we can do a better job as the Crown in educating the folks that have to recognize when a duty to consult is triggered on the front line. The Crown carries the duty to consult, [but] can we use other mechanisms to actually do the consultation? Yes, but we have to be satisfied in the end that whatever mechanism it is, whether it's the community itself that's consulting internally, $[\ldots]$ or a third party, we have to be assured that that duty is ultimately fulfilled. If it's another ministry, we help them understand, but we do need to do a better job of that. [I]n that regard, I think our understanding of what the duty to consult [requires], and what those triggers are, [is] still evolving to some extent. (Reid 2018)

Director Reid's position was echoed by ADM Wedge:

[S]enior folks in our [public service] system [...] don't necessarily have a full appreciation of what these historic grievances [mean to Indigenous communities, such as] flooding, burial sites were washed out; nothing was done, nobody came and talked to us; no provision was made to make us whole for something that happened; land was taken for the road, we were never compensated; you know, somebody came and, in whatever year, got a surrender of a big swath of land, or we surrendered land that was supposed to be sold, it was never sold, and you're still holding it. You know, what are we [in the public service] going to do about that? And so part of my job is to help people understand, for the long-term survival, economic [and] social strength of these communities, the land that gets added becomes part of a stronger base for them to move on to other things. (Wedge 2018)

The second major theme to emerge from my interviews was the distinction between consultation and engagement. "Consultation", as applied by public servants, refers to the legal content of the duty to consult and accommodate, where an Aboriginal rights assessment triggers a formal consultation process. By contrast, "engagement” refers to a host of informal 
communications with Indigenous communities where there may be an Indigenous interest in a policy, regulation, or bill, but no specific rights infringement is being contemplated. (Manager, Ontario Ministry of Health, in conversation with the author 2018, 2; Wedge 2018; Director, Ontario Ministry of Indigenous Affairs, in conversation with the author 2018b; (former) Acting Manager, Ontario Ministry of Energy, in conversation with the author 2018; (former) Legal counsel, Ontario Ministry of Indigenous Relations and Reconciliation, in conversation with the author 2018) As ADM Wedge explained:

[I]t's interesting because I think [...] we have, at times, deep relations with communities that are part of the ongoing relationship. [T] he IRPD [Indigenous Relations and Programs Division] shop downstairs is providing funding for the building of capacity, [and is] working with those communities. We may have situations where, as a result of our land claims and our ongoing relationship with the community - an ongoing engagement with them, I mean - and an ability to do troubleshooting by calling meeting, it's not necessarily a formal consultation. (Wedge 2018)

Typically, the formal consultation process is triggered when the Province is contemplating a land transfer. (Director, Ontario Ministry of Indigenous Affairs, in conversation with the author 2018b; (former) Legal counsel, Ontario Ministry of Indigenous Relations and Reconciliation, in conversation with the author 2018) But in the years since the release of the Truth and Reconciliation Commission report, public expectations have been raised for settler governments to conduct broad consultation and engagement with Indigenous communities. ((former) Legal counsel, Ontario Ministry of Indigenous Relations and Reconciliation, in conversation with the author 2018; Bigelow 2018; Bellefeuille 2020) Not all Crown-Indigenous relations will require a formal consultation process, but equally, informal communications will not satisfy the duty to consult. Provincial public servants must be careful when making sharp distinctions between interest-based and rights-based negotiations, since a process that begins as interest-based 
engagement may uncover rights-based concerns at a later date. ((former) Policy Advisor, Ontario Ministry of Natural Resources and Forestry, in conversation with the author 2020)

The other concern with the informal "engagement" process is that it has no structural basis. Personal relationships between First Nation communities and provincial policymakers can often produce mutually beneficial partnerships, (Whetung 2020; Kapyrka 2021) but the nature of these relationships is highly dependent on the buy-in from public servants, some of whom are more supportive of the reconciliation project than others, or more rigid and by-the-book than others. ((former) Policy Advisor, Ontario Ministry of Natural Resources and Forestry, in conversation with the author 2020; Administrator, Windigo First Nations Council, in conversation with the author 2020) What is needed is a broad-based understanding among public servants of the Crown's duty of honourable dealing, and to cement those duties in co-developed guidelines that are relevant to each ministry's mandate.

This brings us neatly to the third major theme to emerge from my interviews: the need for both sector-specific guidance on Crown-Indigenous consultation, and the broad sharing of information about Indigenous engagement between ministries. Among line ministry staff, a lack of information on conducting Indigenous consultations can lead to a fear of working with Indigenous partners, or a fear of treading of areas of federal jurisdiction. ((former) Acting Manager, Ontario Ministry of Energy, in conversation with the author 2018; (former) Policy Advisor, Ontario Ministry of Natural Resources and Forestry, in conversation with the author 2020) It is critical that the provincial government continues to support (and perhaps actively promote) inter-ministry working groups and legal roundtables that seek to share information on the Crown-Indigenous relationship between ministries. ((former) Acting Manager, Ontario Ministry of Energy, in conversation with the author 2018; (former) Legal counsel, Ontario 
Ministry of Indigenous Relations and Reconciliation, in conversation with the author 2018; Whetung 2020) However, as one interviewee remarked, old habits of managing siloed government departments can make some public service managers overtly hostile to sharing information across government. ((former) Policy Advisor, Ontario Ministry of Natural Resources and Forestry, in conversation with the author 2020)

To the extent that public service training on the Crown-Indigenous relationship is available, it is both voluntary and high-level. Professional education courses are currently available to public servants on colonial histories, Section 35 rights, and reconciliation. This is a good start and should not be discouraged, but similar training should be available to all public servants, not just those working in the Indigenous field, so there is a shared understanding of inherent Indigenous rights across government. For those who are working in the field, there needs to be more specific training on the application of IAOs umbrella consultation policy in sector-specific contexts. In other words, how does the duty to consult and accommodate play out under different mandates? ((former) Acting Manager, Ontario Ministry of Energy, in conversation with the author 2018; (former) Policy Advisor, Ontario Ministry of Natural Resources and Forestry, in conversation with the author 2020; Bigelow 2018; see also Dorries $2012,164)$ This lack of specificity is a source of frustration for frontline staff, who sometimes feel unsupported by senior management. As one former manager put it:

[All provincial ministries] have different mandates, even though we wear one Crown. For example, MIRR['s] mandate ${ }^{36}$ frequently [...] doesn't work well with how things get operationalized. So, if they're creating a general policy about something, there's often resistance from [...] line ministries - people that actually have to implement things. $[\ldots][T]$ here needs to be a much greater understanding, I think, at the decision-making levels about the impacts of these policies, [...] how

\footnotetext{
${ }^{36}$ Under former Liberal Premier, Kathleen Wynne, the Ontario Ministry of Indigenous Affairs was previously known as the Ministry for Indigenous Relations and Reconciliation, or MIRR.
} 
onerous and time consuming it is to change. And if you want us to change how we're doing things, we need you to support us [with] resources and buy-in.

You might have a senior leader telling you to do something, but then when you're implementing things to try to make that happen, [and] they'll resist that change. I think that there has been a lot of resistance from a number of ministries, and I think there has been a recognition that $[\ldots]$ it was pretty top down for a while. Like, "Okay, we're doing this policy. Here you go, implement it." So, I think there has been a bit of recognition that they need to work more closely with the people are going to be implementing the policy. That's in transition, I would say. [...] So even though we're all kind of one Crown, [and] we work together I think to a good extent, $[\ldots]$ we have different mandates. ((former) Acting Manager, Ontario Ministry of Energy, in conversation with the author 2018)

The discrepancy between the high-level IAO guidance on the duty to consult and the implementation work of line ministries is also apparent to the Province's First Nation partners. As Grand Chief of the Mohawk Council of Akwesasne, Abram Benedict, told me:

I think the problem is that you kind of have the ministry experts in the sector, and then you have them trying to feed through the generalized people that work at Aboriginal Affairs. [...] That doesn't always work very well, because they're not the experts. They may be the experts in having a good relationship but, you know, some of this stuff is more technical too, right? (Benedict 2020)

Facilitating inter-ministry communication and providing sector-specific guidance on the Crown's duties of consultation and honourable dealing would not only help ministry staff navigate their constitutional obligations, but could also account for the specific sectoral agreements that many ministries have with First Nation communities. This applies not only to land and resource ministries, but also service agreements with the Ministries of Health and Education, for example. (Bellefeuille 2020; Benedict 2020) These guidelines must be codeveloped with the Province's Indigenous partners, since the framing of consultation policy can have important implications for the exercise of Indigenous rights, and differing treaty 
relationships with the Crown might affect the nature of consultation. Ontario cannot manage effective Crown-Indigenous partnerships by acting alone. Put simply, ministries must consult on consultation. (see Dorries 2012, 164; Association of Municipalities of Ontario 2019, 18)

After consultations take place, there is often also a lack of cooperation and understanding from provincial officials on exercising Aboriginal rights. Dan Kohoko, a long-time Councillor with the Algonquins of Pikwakanagan First Nation, cited one example of his community trying to co-manage harvesting in Algonquin Park:

[W]e used to have our own employed conservation officer that worked with us during our annual moose hunt and when we were fishing, and [Ministry officials] decided that, for whatever reason - I'm not sure why exactly or how it actually happened - but they wouldn't recognize our enforcement office anymore, even [though] at the time they were providing most of the funding that we were using to pay the individual. [...] [I]t made for bad relations there for a while, and it also made for less cooperative enforcement of activities. We were only looking to regulate ourselves. We weren't looking to regulate anyone else; although, if necessary, we would have. (Kohoko 2020)

Similarly, park staff working for the Province are not provided consistent direction on how Indigenous harvesters can gain access to parks, which leads to ad hoc solutions. As one interviewee explained:

So, for example, free [admittance] to parks: you have communities saying that it's their ancestral land, they're exercising their treaty right to do certain ceremonies in the park. They're saying "It's free, we should be able to go in for free", right? So we have this interim guidance that says we have to recognize these rights, but $[\ldots]$ when we tried to do that, and we want to give them a free pass to get into the park, we would get our hand slapped saying, "No, you can't do that, you still have to charge them." So there is this conflict, there is this tension, where we have this direction but when it came to the actual implementation of it there was no clarity. [...] What you often had happening was park superintendents would take it into their own hands and not report it or just sort of wave the cars through and let them in. $[\ldots]$ 
[F]or a researcher or someone on the outside who is reading [policy documents] they're going to be like, "Oh yeah, this is great, Ontario Parks recognizes their rights." But when it comes down to the actual implementation, it's still very vague. ((former) Policy Advisor, Ontario Ministry of Natural Resources and Forestry, in conversation with the author 2020)

It is often easier for park staff to simply deny First Nation harvesters in the absence of clear direction. This discourages First Nations from exercising their treaty rights for fear of being charged by the enforcement officers and dragged to court. (Bellefeuille 2020; (former) Policy Advisor, Ontario Ministry of Natural Resources and Forestry, in conversation with the author 2020)

In addition to sector-specific guidance, a fourth theme which emerged from the interviews was the question of who discharges the duty to consult. As previously discussed in Chapter 4 of this dissertation, the Supreme Court's decision in Haida allowed the Crown to delegate "procedural" aspects of the duty to consult to project proponents. (Haida Nation v. British Columbia (Minister of Forests) 2004a, para. 53) Without a clear legal definition of which aspects of the duty are procedural and which are substantive, (see Sterling and Landmann 2009b, 10) and given their relatively limited manpower, most ministry Indigenous Affairs branches delegate the task of consultation to project proponents. This can have certain advantages, since proponents have both an in-depth knowledge of the project and hold regulatory approvals. ((former) Acting Manager, Ontario Ministry of Energy, in conversation with the author 2018; Bigelow 2018) Nevertheless, proponents may be less versed in the Crown-Indigenous relationship, so line ministries must still oversee the adequacy of consultation, as required under law. There is also a public good argument to be made for more direct Crown involvement in consultations. Government stewardship of land, water, and resources may have broad public benefits which may not align with the profit motives of private sector proponents. (Kohoko 
2020) In some policy contexts, such as provincial parks or highways, the Ontario Crown effectively is the proponent, and so has both the mandate and the capacity to conduct First Nation consultations directly. ((former) Policy Advisor, Ontario Ministry of Natural Resources and Forestry, in conversation with the author 2020; Kapyrka 2021)

Several Ontario First Nations have developed their own local consultation policies to guide proponents in partnering with the community, but generally these local policies get little recognition from the provincial Crown. (Bellefeuille 2020; see also Dorries 2012, 158-61) Equally, the Crown's delegation of consultation to proponents is sometimes met by the refusal of First Nation communities to meet with the proponent at all. ((former) Acting Manager, Ontario Ministry of Energy, in conversation with the author 2018) The collective memory of Canada's colonial past is still acutely felt in many First Nations, and the onus may be on the provincial Crown to proactively take the first step and initiate good faith consultations. As one administrator from the Windigo First Nations Council in northwestern Ontario told me:

I'd say [consultation is] kind of like a [...] two-sided coin. You need to have both parties agreeable to it, and sometimes [...] we've got some communities that would be more agreeable to [...] having those discussions, but we've got others that [are mistrustful because of] those historical wrongdoings, and are not willing to have those discussions. [...] I would say, unfortunately - because this isn't at the forefront of our communities' needs right now - the government would almost have to drive this discussion, which I would say is a little counteractive to the whole thing, in that $[\ldots]$ they're providing direction to the communities that this should be done, instead of the other way around. (Administrator, Windigo First Nations Council, in conversation with the author 2020)

First Nation interviewees generally felt that that the Supreme Court's clarification of Section 35 rights had been helpful in improving relations with provincial ministries, (Bellefeuille 2020) but as with the "interest-based" engagement mentioned above, the Court's lack of clarity 
on delegating the duty to consult has produced a set of informal relationships rather than institutionalized policy. As stated by Councillor Kohoko:

[T] he big court cases [...] really outlined the Crown's responsibility to consult with First Nations people in their territories, [but] they didn't exactly define an exact procedure along those lines. So it's kind of left up to the individual province and/or our [First Nation] government supporting each other in how and what they do. (Kohoko 2020)

Consultation also requires financial resources, both for the Crown and First Nations.

There remains considerable leeway for senior public servants at the Assistant Deputy Minister level to interpret their policy mandates and allocate program funding according to that interpretation. As expressed by one former Advisor:

[T] his is where in the same Ministry you get really different forces, but of course those who control the money really control the final say on things. [...] It really depends on the leadership, it's not always universal. You may have a policy, a universal policy, but how you interpret that [...] often [leaves] leeway for ADMs. ((former) Policy Advisor, Ontario Ministry of Natural Resources and Forestry, in conversation with the author 2020)

This underscores the importance of professional education and sectoral guidance on consultation, so that senior leaders allocate funding to fulfil the Crown's duty of honourable dealing, and frontline staff have the confidence to implement it. (Kapyrka 2021)

The fifth and perhaps most crucial theme to emerge from the interviews is the unilateral action of the Crown in overseeing consultation, and the need to break the cycle of unilateralism. Line ministries determine the significance of an Indigenous rights claim, the scope of consultation and accommodation, and which communities are contacted. (Director, Ontario Ministry of Indigenous Affairs, in conversation with the author 2018b; Bigelow 2018; Whetung 2020) In situations where the asserted Aboriginal rights are not yet recognized by the Ontario Crown, line ministries will often turn to IAO for guidance. (Director, Ontario Ministry of Indigenous Affairs, in conversation with the author 2018b) There was no indication from my 
interviews that Indigenous rights-holders are invited to help determine the severity of rights impacts, and by extension the scope of consultation; and that carries with it certain dangers. As Chief Emily Whetung of the Curve Lake First Nation explained:

The struggle our community is facing right now is having government departments recognize that we, as First Nations, are the only ones in a position to evaluate the impacts of given project on our rights. For example, the Ministry of Transportation doesn't have documented knowledge of where our traplines are and therefore cannot appropriately evaluate the impacts of something as simple as road resurfacing. This is the same across the board - an Environmental Assessment done without First Nation input cannot appropriately assess the impact that a given development would have on, say, a plant species we use for ceremonial or medicinal purposes. This means that our communities have to be advised of, and given the opportunity to provide input on any number of projects that the government may think are 'low impact'. Without our cultural knowledge, without our traditional beliefs, the government cannot appropriately assess the projects impacts. (Whetung 2020)

Similarly, the 2012 consultation policy issued by the Ministry of Northern Development and Mines does not require consultation until after a mining claim has been staked and recorded, (Ontario Ministry of Northern Development and Mines 2012, 2, 5) but this fails to account for the potential impacts of initial exploration on local First Nations. Drilling samples or trenching could destroy archaeological sites before archaeology is ever mandated, or scrape ancient petroglyphs off of rocks; (Kapyrka 2021) all of which underscores the importance of engaging Indigenous communities as early as possible.

Unilateralism by the provincial government in assessing consultation also risks triggering litigation and protest by First Nations, because there isn't enough opportunity for rights-holders to voice their concerns through processes of negotiation. (Bellefeuille 2020; Benedict 2020) Litigation should be avoided by settler governments, as it represents a fundamental breakdown of respect and collaboration. ((former) Legal counsel, Ontario Ministry of Indigenous Relations and 
Reconciliation, in conversation with the author 2018; Government of Ontario 2007, 82;

Department of Justice Canada 2018, 6)

The Province's response to direct action by First Nations has changed dramatically since Ipperwash. As expressed by Fred Bellefeuille, Legal Director for the Anishinabek Nation:

Right now there's a lot more deference to First Nations. If we're having an information campaign, for example, it's respected. It's not seen as a real threat to people's safety. It's more of an assertion that may have merit, as opposed to "the Indians are blocking the road." (Bellefeuille 2020)

Direct action was also credited by some interviewees for informing IAO's interim guidance on consultation. ((former) Policy Advisor, Ontario Ministry of Natural Resources and Forestry, in conversation with the author 2020) Nevertheless, protest, like litigation, represents a breakdown of the trust relationship between First Nations and the Province. Furthermore, it is unpredictable and carries substantially more policy risk than a negotiated settlement developed through consultation and accommodation.

After consultation has taken place, there is also generally no opportunity for Indigenous communities to debrief with line ministry staff on the adequacy of consultation. (Bigelow 2018; (former) Policy Advisor, Ontario Ministry of Natural Resources and Forestry, in conversation with the author 2020) Typically, project proponents will submit a consultation report directly to the ministry. ((former) Acting Manager, Ontario Ministry of Energy, in conversation with the author 2018) In policy contexts such as provincial parks where the Crown acts as proponent, ministry staff will file internal documents known as an Aboriginal Consultation Information Templates, or ACITs, describing key takeaways from the consultation process. In their current iteration, ACITs must also be completed for each rights-holding community, and cannot be grouped into multiple communities affected by the same park project. As one interviewee told 
me, this requirement entrenches duplicate processes and takes valuable time away from actual park management. ((former) Policy Advisor, Ontario Ministry of Natural Resources and Forestry, in conversation with the author 2020)

This raises another consideration when governments are consulting in good faith: do consultation processes actually hinder First Nation-led interests? On the government side, this usually involves multiple layers of regulatory approval. For example, when contemplating an addition to reserve lands, the Province will initiate consultation through its environmental assessment process, and once completed, the federal government also conducts consultation on the addition to reserve itself. (Director, Ontario Ministry of Indigenous Affairs, in conversation with the author 2018b) These multi-layered processes do not run concurrently, which costs the affected communities additional time and engagement resources.

On the First Nations side, many rural and remote communities have an interest in critical infrastructure projects such as all-season roads linking them to the provincial highway system. However, because of local climate conditions the construction season is very short. Extended consultation processes are important to satisfy regulatory approvals, but this can cause an entire construction season to be missed, requiring the continued use of ice roads which are known to pose potentially fatal risks to drivers. In cases where development comes at the request of the First Nation community, streamlining the consultation process can be in the public benefit. (Administrator, Windigo First Nations Council, in conversation with the author 2020) This further underscores the need for line ministries to share information and act as one Crown, so that both planners and regulators can coordinate their consultation processes and avoid duplication. (see Sterling and Landmann 2009b, 8; Hunter, Sahni, and McKibbon 2012, 4) 
Overall, there needs to be greater policy space for First Nation-led agendas in consultation. Many interviewees, in contrasting provincial and federal approaches to consultation, pointed out that the scope of Ontario's consultations is frequently narrow and delineated; and mused that perhaps the federal government is more practiced with its fiduciary obligations to Indigenous communities. (Benedict 2020; Bellefeuille 2020; Whetung 2020) As Fred Bellefeuille explained,

There definitely is a difference. [...] Canada takes a very broad approach to consultations, and Ontario's more focused. Canada is much more open about consultation that shifts to what First Nations want to talk about. As an example, when consulted on the impact of Court and human rights cases on Indian Status, First Nations were able to focus on self-identification - sometimes called citizenship. [...] Ontario wants to be more focused on an issue - they are very specific. [...] They want feedback on their policy, not new ideas or ways to not infringe rights. They want feedback on which infringement is preferred, as [in] what we think is the least infringing on the right. (Bellefeuille 2020)

This opinion is echoed in recent scholarship on the implementation of Section 35 rights. As Pam McCurry argues, the Supreme Court's vision of reconciled Crown-Indigenous relations should not be interpreted in a minimalist or technocratic way. Grounding the duty to consult and accommodate in the broadly-defined "honour of the Crown," and the application of these duties to asserted rights that do not have to be proven means that the Court has repeatedly emphasized relationship as a model for the Crown's conduct. (McCurry 2020, 404)

Nevertheless, technocratic and contractual interpretations repeatedly surfaced as a concern among by First Nation interviewees. In more complex consultations, such as in the context of land claim negotiations, First Nation claim areas will frequently incorporate multiple layers of land use such as roads, railway lines, power line corridors, parks, private land, Crown land, and reserve land, to name just a few. (Wedge 2018) The concern among some of the First 
Nation leaders I spoke to was that even non-treaty agreements, such as land use plans or agreements-in-principle, would be interpreted by provincial officials as a delineation of Indigenous territory, preventing them from exercising rights to land never formally ceded to the Crown. (Kohoko 2020; Administrator, Windigo First Nations Council, in conversation with the author 2020) Even if these boundaries are likely non-justiciable, given the law surrounding Section 35 rights, they still exert social pressure on affected communities. As described by Fred Bellefeuille,

Almost every First Nation you go to has some kind of social boundary, I guess you'd call it. By social boundary I mean a church, school, game preserve, Crown land, etc. Not a fence, but a social fence of some type, to keep the First Nation people in their place. (Bellefeuille 2020)

In a similar vein, Councillor Kohoko spoke of the 2016 Agreement-In-Principle reached between members of his community of Pikwakanagan and the federal and provincial governments. He stated that a non-binding clause inserted into the AIP was designed to guard against the document being treated as a contract, until further negotiation with rights-bearing First Nations produced a new modern treaty. (Kohoko 2020)

In my conversation with ADM Grant Wedge, he related an anecdote about inviting James (Sakèj) Youngblood Henderson to a government training session. Recalling Chapter 2 of this dissertation, we know Henderson as the intellectual godfather of Treaty Federalism. As ADM Wedge described,

I brought [Sakèj Henderson] into a training session that we were doing with lawyers around duty to consult. This is when I was Legal Director, about six years ago. And he said to people, "I don't understand why you people from government think it's OK to walk into a community and say something bad is going to happen, we're here to talk about it. You know, why don't you invest in developing a 
relationship with the community, rather than waiting to the last minute to come?" (Wedge 2018)

None of the concerns raised above should be interpreted to mean that there has been no progress in the relationship between First Nations and the Ontario Crown. First Nation interviewees unanimously declared that the relationship had improved in the years since the Haida decision, and provided some examples of where relationships with policymakers had led to First Nation accommodations. The Ministry of Natural Resources and Forestry, for example, was credited for sharing services in kind to facilitate consultations, such as mapping, environmental screening reports, tracking and survey data of migratory caribou herds, and sponsored travel. (Administrator, Windigo First Nations Council, in conversation with the author 2020) On legislation, feedback from First Nations saw changes to the 2020 Security from Trespass and Protecting Food Safety Act, including the addition of a non-derogation clause (much like Section 25 of the Charter of Rights and Freedoms) which exempts Aboriginal and treaty rights from the definition of trespass. (Benedict 2020; see Government of Ontario 2020, sec. 4) On the government side, the construction of bridges in harvesting areas have been delayed so as not to coincide with the fishing season in local communities. (Bigelow 2018)

There is measurable progress, but as we have seen there are also important ways that Crown-Indigenous relationships can improve. What is needed is a whole-of-government strategy which incorporates Indigenous consultation, co-development, and co-management into the policy cycle. This is likely a generational project, but governments cannot escape this responsibility, as it is woven into the fabric of our constitutional law. Renewing these partnerships must first start with the acknowledgement that all the wealth contained in the 
Ontario economy, and indeed Canada as a whole, is built upon resources drawn from Indigenous territories. As summarized by Chief Whetung,

There can be a fear or guilt when it comes to engaging with the issues of reconciliation. We all need to be committed to rebuilding this relationship, but to get there we need to recognize the underlying truth that is our history. Without the support and cooperation of First Nations Canada would never have been able to access the natural resources here. Those natural resources are the foundation of our economy. We can't shy away from having real conversations about how history led us to this point. Those conversations can be hard and can cause people to feel guilty, but anyone who is committed to making the relationships better has no need to feel guilty. It's time we all make a commitment to fixing this relationship - there is no in between. (Whetung 2020)

This commitment will take both human and financial resources. Without a renewed fiscal relationship between Indigenous peoples and the provincial and federal Crowns, the work of reconciliation will be limited in what it can accomplish. First Nations must have the predictable funding to act as an order of government under treaty law. As stated by Councillor Kohoko:

[F]rom a government point of view, if we were to become self-governing [...] we'd want to be able to raise our own money. We would not want to be dependent on Canada or Ontario to give us money piecemeal as they [...] saw fit. [...] [W]e ought to be able to raise money through taxes the same way the other levels of government do. [...] [M] unicipalities are able to tax $[\ldots]$ their residents in their area $[. .$.$] and Ontario also levies taxes, and so does Canada in the territory of$ Ontario, if you will. And we think we need to be able to do that type of deal ourselves, and there are many mechanisms to do it, [...] for example, where Canada and Ontario cooperate with each other [on] the HST. (Kohoko 2020)

Providing staple and predictable funding for Indigenous engagement also allows First

Nations to expand their professional administration, and frees up political leaders to pursue strategic planning. (Lysyk 2020, 3) As Grand Chief Benedict explained:

I want to make sure that those systems are separated between administration and governance. They interact, certainly, but it's more [that] members of my council are elected to lobby governments, work externally [...] with federal and provincial governments, work with stakeholders, not micromanage in the weeds, 
right? So I want to make sure that the systems are all there to support [them so that] they're not in the weeds, but rather thinking about the larger picture [and] policy development. (Benedict 2020)

Aside from capacity in Indigenous government, there is also need for greater diversity in public government. More Indigenous voices in the ranks of the public service can only help broaden institutional perspectives and educate ministry staff about their constitutional relationships. (Kohoko 2020; Benedict 2020) Indigenous people have always been ready to engage with government, and to foster long-term relationships with the public service. As said by Chief Whetung:

I would say that [for me and my community,] it is absolutely about [...] building those relationships so people want to help; so that the civil service wants to engage with me, and wants to find solutions. I also think that [relationshipbuilding is] about finding [...] ways that [affirming Indigenous rights] will impact and make sense to the province. Because it's easier and makes more sense to engage with my community and the small asks that we have [before committing to] those sort of heavy-handed, higher-priced engagements that other nations are asking for.

[...]

I think what a lot of the communities forget is when the province is prosperous, our communities have the opportunity to be prosperous. [...] If there are strong relationships, then you don't forget about the people who helped you get there. $[\mathrm{S}] \mathrm{o}$ if there's a really strong written, clear understanding of how those relationships are going to work, then you can't really forget [your] neighbour when times are lean because it's there, it's consistent, it's continuing and ongoing. It's not moment by moment. (Whetung 2020)

Overall, these interviews show that many Ontario public servants are devoting themselves to the work of reconciliation, but the policy process is lagging behind. Nearly 29 years after the inclusion of Section 35, 25 years after the Royal Commission on Aboriginal Peoples, 15 years after Haida, and 6 years after the Truth and Reconciliation Commission, implementing the Crown's duty of honourable dealing is nowhere near the whole-of-government 
approach that it needs to be. (see Association of Municipalities of Ontario 2019, 19)

Nevertheless, as public knowledge of Crown-Indigenous relationships increases, we may be on the cusp of a new era of mutual recognition, respect, and cooperation. As one interviewee put it:

It's really trying to actualize co-development and day to day practice. And so "what does that look like?" is a good question, because I don't have a guidebook. I just do this in terms of what respectful relationship-building [might] look like, and that is giving [Indigenous stakeholders] as much advanced notice [of an upcoming] policy as I can.

Now for me in my current role I work with national organizations and political representative bodies, right? You don't get that at a provincial level, so much. But I think that's the general trend you're going to start seeing. They're going to start doing things not because they're legally obligated to, it's because they want to start giving a heads up to groups as early as they can about something, and giving them the opportunity to give informal feedback to managers on the ground. ((former) Policy Advisor, Ontario Ministry of Natural Resources and Forestry, in conversation with the author 2020)

This assertion is supported by the comments of First Nation representatives. For instance,

Julie Kapyrka of the Curve Lake First Nation offered the following advice:

[T] he one thing that I always encourage is early engagement. If people ask me 'what's your one piece of advice to us,' I say engage as early as you can, and then engage earlier than that. [...] [E]ven better, create relationships prior to that. So if you have a relationship with us and a project comes down the line, we already know you and we're going to pick up the phone if we have questions or concerns, because we know you. [...] [I]f we already have a relationship, we can hit the ground running when a project does come down the line. (Kapyrka 2021)

Councillor Kohoko shared a particularly elegant metaphor for reconciled CrownIndigenous relationships, which I will paraphrase here. He described a three-cross braid of sweetgrass, where each strand represents an order of government: federal, provincial, and Indigenous. As they intertwine, each strand will alternately sit atop while the other strands are subordinate, representing shared and co-equal jurisdiction. Most importantly, the braid as a whole is substantially stronger than any individual strand. (Kohoko 2020) 


\section{E. A Snapshot of Consultation in Other Canadian Provinces and Territories}

Following this examination of Ontario's consultation policies, it's worth a brief examination of how certain other Canadian provinces and territories approach their own consultations with Indigenous people. Like Ontario, Alberta and Saskatchewan have large Indigenous populations and are covered by treaty areas. However, Saskatchewan (along with Manitoba and British Columbia) has a treaty commission, where Alberta does not. (Narine 2020) Does this produce any marked difference in their approach to consultation?

Much like Ontario, Alberta produced its own consultation policy in the wake of the Haida decision, introducing the snappily titled Government of Alberta's First Nations Consultation Policy on Land Management and Resource Development in May 2005. The "guiding principles" set out in the policy reflected judicial concepts such as a spectrum analysis of the duty to consult, a commitment to consulting in good faith, and minimizing rights infringements. The Policy also noted that "procedural aspects" of the duty to consult could be discharged by private sector proponents, and so expected these proponents to lead the way on community engagement. (Reddekopp 2013, 51) In November 2007, the Government of Alberta followed the Policy with a set of consultation guidelines including both government-wide and department-specific guidelines. The provision of department-specific guidelines was perhaps an

advancement over Ontario policy, but the Alberta approach still suffered from that most common mistake of settler governments: unilateralism. Alberta's policy reserved the Province's exclusive right to determine (1) which projects required consultation, (2) the scope of consultations, and (3) the adequacy of accommodations. (Reddekopp 2013, 52-53)

Unsurprisingly, Indigenous peoples were not involved in the Policy's design, and this unilateral approach led First Nation Chiefs to formally reject the Policy in 2006, and after the 
departmental guidelines were released, to reaffirm their rejection in September 2009.

(Reddekopp 2013, 52) Nevertheless, Neil Reddekopp writes, Alberta First Nations had remarkably little direct action and litigation over consultation issues as compared to other provinces. He argues that this is the product of a combination of First Nations' pragmatism, political pressure, and industry's willingness to fill gaps left by the Alberta Crown:

[T] he most plausible answer must be that whatever qualms industry and First Nations might have about the legality of having no alternative but to deal with each other with almost complete absence of the Crown as a participant in consultation processes, the remaining parties have achieved what they can, given the reality they face. [...]

To a large extent, industry's willingness to negotiate with First Nations is based on the fear that a failure to reach an agreement with them might lead to considerable delay in a project. But the Crown's apparent commitment to ensuring the expansion of oil sands projects is such that while industry's fear of delay can lead to a positive outcome, an actual delay cannot be contemplated. This is particularly true when First Nations or Aboriginal communities allege that a project should not proceed because of the failure by the Crown to meet it constitutional obligations regarding consultation $[\ldots]$

For industry, particularly those engaged in oil sands development, the substantial cost of reaching agreements with First Nations is, relatively speaking, such a tiny portion of the total cost of and return from projects that industry has been able to absorb the cost of agreements as a manageable part of doing business. (Reddekopp 2013, 55-58 emphasis added)

In August 2013, Alberta released an amended version of the Policy, (Land 2014, 11) but in some respects the new policy is more regressive than the old. The new policy outlined three levels of consultation, each of which imposed a particular fixed timeline for First Nations to provide a response to project notifications. The Policy also exempted the leasing of lands or licensing of mineral rights from consultation. (Land 2014, 12-13, 15)

Alongside the revised Policy, Alberta also passed the 2013 Levy Act. The Act had the laudable goal of supporting First Nation consultations by imposing a specific levy on industry. However, the terms of the Act led it to be strenuously rejected by First Nations in the province. 
In the preamble to the Act, First Nations are defined according to the Indian Act, which not only leaves out non-Status communities, but also the entirety of Alberta's substantial Métis population. (Land 2014, 16-17) Following the Province's pattern of unilateralism, the Minister of Finance could exempt individual proponents or entire classes of proponents from the levy, and the Minister's decision would not be subject to review. Furthermore, any penalties collected from proponents from their failure to pay the consultation levy would not be deposited into the consultation fund, but rather into general revenues. (Land 2014, 13-17) Overall, the Alberta Crown's recusal from most Indigenous consultation, makes the federal Crown's duty of honourable dealing all the more important on national-level projects such as pipelines.

The Government of Saskatchewan's 2010 First Nation and Métis Consultation Policy Framework, which currently remains in effect, also shows similar features to Ontario and Alberta policy, and is perhaps a mixed bag when it comes to the language around Aboriginal rights. Like the other provincial Crowns, the Government of Saskatchewan reserves the right to determine the credibility of a rights claim and the scope of consultation required. ("First Nation and Metis Consultation Policy Framework" 2010, 2, 15) The stated goal of the policy framework is to foster Crown-Indigenous relationships "that contribute to a growing provincial economy", ("First Nation and Metis Consultation Policy Framework" 2010, 3) which perhaps betrays a development bias within the policy. Like Alberta's policy, the Saskatchewan framework also attributes fixed response timelines for each level of consultation, but in fairness this tops out at 45 days compared to 20 days in Alberta. ("First Nation and Metis Consultation Policy Framework" 2010, 10; Land 2014, 15; Ariss, Fraser, and Somani 2017, 31-32) Saskatchewan's policy framework is similar to the Ontario approach, in that it distinguishes between "rightsbased" engagement and "interest-based" negotiation. ("First Nation and Metis Consultation 
Policy Framework" 2010, 16) But the framing of Government-recognized rights has a significant impact on how the duty to consult is implemented.

Language and discourse seems to be a consistent issue in the policy framework. In describing the Province's role in the duty to consult, the framework alternately states that the "Government retains final decision-making authority" on consultation processes, and also that "The Government is responsible and ultimately accountable for managing the duty to consult." ("First Nation and Metis Consultation Policy Framework" 2010, 4, 7) These statements imply very different approaches to partnership in consultation.

This chapter has criticized Ontario policy for being too high-level for consistent application across ministry mandates, but this is perhaps even more acute in the Saskatchewan framework. The policy's preamble describes the framework as the direction for ministries, agencies, Crown corporations, and proponents on consultation and implementation in First Nation and Métis communities. ("First Nation and Metis Consultation Policy Framework" 2010, 2) This leaves little specific consideration of different institutional contexts or relationships with the Crown.

Borrowing from the 1996 R. v. Van Der Peet decision, Saskatchewan's policy framework also grounds Aboriginal rights firmly in pre-contact practices by only recognizing rights that are "integral to the distinctive culture" of Indigenous people. ("First Nation and Metis Consultation Policy Framework" 2010, 5, 15) The policy framework affirms that treaties are "living, breathing documents that continue to bind us to promises made generations ago", but then immediately declares that these are to be interpreted according to their written text, and that "oral histories of the First Nations offer a different view of the intent of Treaties. It is not the purpose of this policy to attempt to resolve these differences." ("First Nation and Metis Consultation Policy 
Framework" 2010, 14) Accordingly, this leads the government to believe that Aboriginal title was ceded to the Crown in Numbered treaties. Though the policy was drafted before the 2014 Tsilhqot'in decision affirming Aboriginal title, as of writing the framework continues to be in force and makes the Province's position on title abundantly clear: "The Government does not accept assertions by First Nations or Métis that Aboriginal title continues to exist with respect to either lands or resources in Saskatchewan. Accordingly, decisions claimed to adversely affect Aboriginal title are not subject to this policy." ("First Nation and Metis Consultation Policy Framework" 2010, 6) In cases where financial compensation is required for the provincial Crown's infringement of Aboriginal or treaty rights, the "Government will determine compensation on a case-by-case basis and will not address past actions." ("First Nation and Metis Consultation Policy Framework” 2010, 13)

Overall, we can surmise that while the Saskatchewan Crown is more directly involved in consultations than Alberta's, the existence of a Treaty Commission in that province has not led Saskatchewan to a more inclusive interpretation of treaties than their neighbours. But this also relates to the structure of the Treaty Commission itself. The Office of the Treaty Commissioner is an independent body established in 1989 in a partnership between Saskatchewan First Nations and the Government of Canada. The Government of Saskatchewan is only an observer in this body, and is, therefore, distanced from implementing the OTC's mandate. (Stonechild 2018) This underscores the importance of including Indigenous perspectives in policy development, and institutionalizing Crown-Indigenous partnerships, which bring us neatly on to the example of the Northwest Territories (NWT).

As a territorial government empowered through federal statute rather than a constitutionally entrenched province, the NWT is institutionally very different from Ontario. 
That being said, the NWT's commitment to institutionalizing Crown-Indigenous relationships is perhaps a model for the rest of the federation. Jerald Sabin remarks that Indigenous governments in the NWT are in a stronger constitutional position than the territorial government itself, as Indigenous governments hold inherent rights and are recognized and affirmed through Section 35 , whereas the territorial government is empowered through statutory powers devolved from Ottawa. Furthermore, the territory has an overwhelmingly Indigenous majority population. Given the Government's position, establishing a series of policy forums for ongoing discussions with Indigenous governments was a pragmatic policy response. As Sabin argues: “The use of federal-type institutions to formalize and routinize these intergovernmental relations - and to mediate conflicts of law and policy - is a prudent solution [...]. In the NWT, these institutions are moving beyond consultation to structures that enhance government-to-government relationships among all levels of government.” (Sabin 2017, 6)

The largest of these institutions is the Intergovernmental Council of the Northwest Territories (IGC NWT) which acts as a forum for discussion and deliberation, provides policy analysis and recommendations to members, has a permanent secretariat, and hosts annual meetings. The fact that many of the IGC's discussions are conducted in camera has let to public accusations that the Council is elitist and unaccountable. However, the IGC carries no independent decision-making authority of its own - that continues to be vested in participating governments themselves. In this sense, the IGC is much like the First Ministers' meetings organized between settler governments in the Council of the Federation. (Sabin 2017, 14-17) Since 2014, member governments have also negotiated direct fiscal relationships with each other, rather than being funded through separate federal transfers. Indigenous governments co- 
manage the NWT's natural resource development and regulation; and share $25 \%$ of the revenues.

(Sabin 2017, 12, 18-19)

The NWT may prove an important example for other Canadian jurisdictions as they move to decolonize their institutions. As Sabin writes,

The accomplishment of northern peoples in peacefully negotiating, designing and implementing this model of power sharing should be underscored. [...] Indigenous and settler governments are willing to engage in formal and ongoing processes of political and policy deliberation with the goal of greater coordination and integration. As a model of decolonization, this new federation within a federation respects the autonomy of it composite governments while providing sufficient pathways to collaboration. (Sabin 2017, 21)

\section{F. The State of Federal Leadership in Crown-Indigenous Partnership}

Relative to provincial policies, the federal government's approach to Indigenous consultation has seen a marked change in recent years. The release of the Truth and Reconciliation Commission (TRC) report in the summer of 2015 garnered most of the public attention, but another federal report relating more specifically to Crown-Indigenous consultation was, at least initially, withheld from public view. In May 2015, lawyer Bryn Gray was appointed as a Ministerial Special Representative to then Conservative Minister of Aboriginal Affairs and Northern Development, Bernard Valcourt. Gray was asked to seek input and provide recommendations on Canada's consultation and accommodation policies. After months of submissions, the Gray Report was delivered in May 2016 to the new Liberal Minister of Indigenous and Northern Affairs, Carolyn Bennett, but for reasons unexplained was withheld from public release until June 2017. (Munson 2017) The report outlines some 47 recommendations to the federal government, including many that are relevant to the conclusions of this research. These include (2) identifying priorities with Indigenous partners relevant to the 
specific mandates of federal departments and agencies; (9) enhancing federal information and training on modern and historic treaties; $(12,14)$ providing detailed guidance to federal officials on rights and impact assessment; (22) mandate-specific training on the duty to consult and relationship-building for federal officials; (23) greater transparency, including debriefing Indigenous communities on how their concerns were taken into account; (31) coordinating consultations across ministries and governments to reduce the capacity burden on Indigenous communities; and (42) clarifying guidance on precisely what "procedural aspects" of consultation can be delegated to proponents. (B. Gray 2016)

Soon after being sworn into office, the Liberal government of Prime Minister Justin Trudeau repeatedly and publicly made commitments to implementing the Calls to Action of the TRC. These commitments were followed by a succession of agreements with prominent Indigenous organizations, including the 2017 Inuit-Crown Partnership Agreement, ("Inuit Nunangat Declaration on Inuit-Crown Partnership" 2017) the 2017 Assembly of First NationsCanada Memorandum of Understanding on Joint Priorities, ("Assembly of First Nations Canada Memorandum of Understanding on Joint Priorities" 2017) and the 2019 Métis Nation of Ontario-Canada Self-Government Agreement. (Madden and Winterburn 2020)

On the public service side, this new direction from Cabinet required new efforts to coordinate between line ministries on Indigenous policy. With this in mind, a new Deputy Minister's Task Force on Reconciliation was formed in 2017. The mandate of the Task Force is to "focus on managing the political and operational issues related to implementation of the Indigenous reconciliation agenda [and to] facilitate horizontal engagement on major initiatives." ("Deputy Minister Committees: Committee Mandates and Membership" 2020) As of writing, the 
Task Force is chaired by the chaired by the current Deputy Minister of Natural Resources Canada, Christyne Tremblay.

Talking points from a meeting of the Task Force in July 2017, obtained though Access to Information, reveal a series of important strategies for pursuing reconciliation, but few actionable decisions. For example, the Task Force identified as a priority the need for a whole-ofgovernment approach to reconciliation, as well as governance structures to support this. To expedite the implementation of the TRC Calls to Action, the Task Force suggested establishing working groups organized along CTA themes, with lead departments responsible for coordination and guidance on shared responsibilities, thus avoiding duplication. The documents also discuss a review of CTAs to determine which require specific financing, and the necessity of tracking CTA implementation. (Review of Laws and Policies Secretariat 2017, 5-9) Such commitments to coordination are promising, but it is not clear from the documents where these commitments led. Importantly, these commitments remain largely internal to the federal public service and leave Indigenous-led approaches as a secondary consideration.

When considering the inclusion of Indigenous voices in decisionmaking, the Task Force contemplated inviting representatives from National Indigenous Organizations to "share their perspectives on reconciliation in the public service" (Review of Laws and Policies Secretariat 2017, 3), but could not decide whether the Congress of Aboriginal Peoples or the Native Women's Association of Canada should be included, since the government considers them "associations" rather than representative organizations such as the Assembly of First Nations, Métis National Council, and Inuit Tapiriit Kanatami. Inviting CAP and NWAC could, according to the Task Force, open the door to many other Indigenous associations. (Review of Laws and Policies Secretariat 2017, 10) In a similar vein, the Task force contemplated inviting 
representatives from individual communities (the Mikisew Cree were considered as an example) (Review of Laws and Policies Secretariat 2017, 4) to discuss their relationship with the federal public service. Overall, the documents obtained reveal a lack of clarity among federal Deputy Ministers over who speaks for Indigenous governments. Answering this question depends greatly on the scope of the policy being considered, and a one-size-fits-all approach is not appropriate in the context of diverse Indigenous histories and treaty relationships.

Many departments in the federal government, much like their provincial counterparts, are not used to being responsible for Indigenous engagement within their respective mandates, deferring generally to the central Ministry of Indigenous Affairs. However, if Indigenous sovereignty is to be truly recognized by settler governments, then they must be treated as governments, with mostly the same jurisdictional concerns as any other. Though it remains a work in progress, policy forums such as the Deputy Ministers' Task Force on Reconciliation represent a promising step toward better communication and information sharing across ministries. Over time, this approach will hopefully facilitate the federal government's ability to act as one Crown.

Another significant part of the Trudeau Government's approach to reconciliation is the 2018 Principles Respecting the Government of Canada's Relationship with Indigenous Peoples. At least four of the ten principles outlined in the document borrow directly from Supreme Court jurisprudence on Section 35 rights. These include: (2) "Reconciliation is a fundamental purpose of section 35 of the Constitution Act, 1982" (R. v. Van Der Peet, 1996); (3) "The honour of the Crown guides the conduct of the Crown in all of its dealings with Indigenous peoples" (Haida Nation v. BC, 2004); (7) “...any infringement of section 35 rights must by law meet a high threshold of justification which includes Indigenous perspectives and satisfies the Crown's 
fiduciary obligations." (R. v. Sparrow, 1990); and (9) "Reconciliation is an ongoing process that occurs in the context of evolving Indigenous-Crown relationships." (Haida Nation v. BC, 2004) ("Principles Respecting the Government of Canada's Relationship with Indigenous Peoples" 2018)

What distinguishes the Principles from Canadian jurisprudence, however, is the document's willingness to incorporate elements of international human rights law, (Department of Justice Canada 2018, 3) explicitly recognizing the right of self-government as flowing from Indigenous peoples' right to self-determination (Principle 1), and that meaningful engagement aims to secure the free, prior, and informed consent of Indigenous rights-holders (Principle 6). The Principles also affirm that self-government is a part of Canada's system of cooperative federalism (Principle 4). (“Principles Respecting the Government of Canada's Relationship with Indigenous Peoples" 2018; see also Department of Justice Canada 2018, 7; McCurry 2020, 405)

Similar to provincial guidance documents on Crown-Indigenous relationships, the Principles outline high-level commitments, and need sector-specific guidance for implementation within ministry mandates. One such example is the Directive on Civil Litigation Involving Indigenous Peoples, issued by then Minister of Justice and Attorney General of Canada, Jody Wilson-Raybould in 2018. Perhaps unsurprisingly, the directive from the Chief Law Officer of the Crown contains references to judicial dialogue. This includes the acknowledgement that reconciliation is a fundamental purpose of Section 35, that reconciliation is an ongoing process, that good faith negotiation is preferred over litigation, that oral history is admissible as evidence of Aboriginal and treaty rights, and that the Crown must act honourably in all its dealing with Indigenous peoples. (Department of Justice Canada 2018, 6-7, 13, 20) 
The directive offers similar arguments as this research concerning the deferral to courts

where political negotiations broke down, and that these negotiations must be revived:

The nature of section 35 litigation has always been unique. When section 35 was included in the Constitution Act, 1982, it was agreed further political work needed to be done regarding its implementation. Attempts to advance understandings and implementation of section 35 occurred over the course of four constitutional conferences in the 1980s, and through two attempts at constitutional amendment. The lack of success in this work contributed to the courts assuming a leading role in defining section 35. In this way, litigation became a central forum to resolve major issues in the Crown-Indigenous relationship as opposed to a forum of last resort focused on specific areas or issues in dispute.

Litigation is by its nature an adversarial process, and it cannot be the primary forum for achieving reconciliation and the renewal of the Crown-Indigenous relationship. This is why a core theme of this Directive is to advance an approach to litigation that promotes resolution and settlement, and seeks opportunities to narrow or avoid potential litigation. Our Government is committed to pursuing dialogue, co-operation, partnership and negotiation based on the recognition of rights.

We recognize, however, that Indigenous peoples are entitled to choose their preferred forum to resolve legal issues, that some matters will require legal clarification, and that at times litigation will be unavoidable. [...]

This Directive pursues the following objectives: (1) advancing reconciliation, (2) recognizing rights, (3) upholding the honour of the Crown, and (4) respecting and advancing Indigenous self-determination and self-governance. These objectives, and the guidelines for litigation counsel they promote, are interrelated. [...]

Adversarial litigation cannot and should not be a central forum for achieving reconciliation. This is a message the Supreme Court of Canada has sent time and time again, strongly encouraging that the work of reconciliation take place through political, economic, and social processes that involve negotiating, building understanding, and finding new ways of working together. (Department of Justice Canada 2018, 4, 6)

The directive offers some 20 specific guidelines for Crown attorneys. These include: (1) the application of the Government's 10 Principles over the lifespan of a file, including litigation begun before the Principles were issued; $(5,12)$ adopting a recognition-based approach to Aboriginal and treaty rights in formulating a legal position; (15) allowing Indigenous peoples to define their own rights-bearing collectivities; and (16) only involving multiple jurisdictions in 
litigation where there is an evidentiary basis for doing so. (Department of Justice Canada 2018, $8,12,17,19-20)$ The directive also confines litigation to the answering of specific legal questions (18), and that Crown counsel should seek to avoid litigation both before and during the litigation process through negotiation or alternative dispute resolution $(3,4)$. (Department of Justice Canada 2018, 10-11) This also includes Crown counsel debriefing ministerial staff at the conclusion of litigation, so that legal questions are not re-tried, and triggers for litigation are avoided in future (20). (Department of Justice Canada 2018, 22)

Like their provincial counterparts, federal departments are clients of Crown counsel. (Department of Justice Canada 2018, 5) This makes the Attorney General's directive all the more important for coordinating a whole-of-government approach, such that federal ministries and agencies are acting as one Crown. (Department of Justice Canada 2018, 9, 13) Overall, the directive is an important example of sector-specific guidance on implementing the settler recognition of Indigenous rights, but as of writing there is not enough publicly available evidence to determine whether these guidelines are, in fact, being implemented. Aside for the Attorney-General herself being a prominent Indigenous leader, it is not clear whether Indigenous perspectives were taken into account in the directive's creation, despite its good intentions.

This well-intentioned unilateralism has proven a problem elsewhere in the Trudeau Government's approach to reconciliation. In September 2018, seven months after the release of the Principles, the federal government unveiled a new Recognition of Rights Framework which was intended as the basis for the entire federal government approach to Indigenous relations. Yet in December, the Framework was formally rejected by Chiefs-in-Assembly of the AFN. Among the reasons given by the AFN was that Ottawa had not sufficiently consulted Indigenous communities in the Framework's creation, and that such a wide-ranging approach must be 
Indigenous-led. In other words, Indigenous peoples hold the right to determine the terms of their own recognition. Furthermore, the Framework had no provision for the involvement of provincial governments in the new relationship. Given the jurisdiction provincial governments occupy over lands and resources in Indigenous territories, this is a serious oversight. (Assembly of First Nations 2018a; King 2018)

If the federal government is committed to a whole-of-government approach to reconciliation, it ought to look to its past for a successful model of broad-based Indigenous consultation. The 2005 Kelowna Accord, although stymied in its implementation by the incoming Conservative government of Prime Minister Stephen Harper, continues to be a highwater mark in Crown-Indigenous negotiation. The Accord was intended to repair relationships with Indigenous peoples and close persistent socio-economic gaps between Indigenous and settler Canadians. The process included provincial, territorial, and Indigenous governments, and the five National Indigenous Organizations. Negotiations were organized around sectoral roundtables identified as priority areas by Indigenous participants. These included health, lifelong learning, housing, economic opportunity, and negotiation and accountability. As Alcantara and Spicer said of the Accord: "by allowing indigenous [sic] groups to set the priorities and drive the process, the federal government achieved something that is rare in Aboriginal policy: a sense among indigenous leaders that meaningful consultation had occurred." (Alcantara and Spicer 2015, 96) The Accord also contemplated multiple phases of implementation. Major structural changes to the Crown-Indigenous relationship were deferred to a second five-year agreement yet to be negotiated. Initial implementation would focus of poverty-mitigation efforts to first relieve some of the fiscal burden on Indigenous communities 
and allow Indigenous leadership to focus their attention on governance. (Alcantara and Spicer 2015, 96)

Fiscal relationships continue to be a challenge to implementing the duty to consult and accommodate, as well as the reconciliation agenda more broadly, but efforts are currently underway to address these challenges. In June 2019, the federal Joint Advisory Committee of Fiscal Relations released an engagement document which committed to the pursuit of new fiscal relationships. As stated by the Joint Committee:

The Committee envisions a future where Crown-First Nation relationships are based on respect and trust, a future where Nation-to-Nation relationships honour the original spirit and intent of Treaties. These Nation-to-Nation relationships necessarily include fiscal relationships that provide First Nations with the ways and means to finance their autonomous functions and advance the well-being of their nations, communities and citizens [...] For the fiscal relationship to achieve its full potential for First Nations, it will require honouring of Treaties, and recognition of inherent rights, title and jurisdiction. ("Honouring Our Ancenstors by Trailblazing a Path to the Future: Interim Report of the Joint Advisory Committee on Fiscal Relations - for Engagement Purposes" 2019, 5)

Among the Joint Committee's draft recommendations were increased tax jurisdiction for First Nation governments; tripartite decisionmaking processes; stable funding to support capacity in the short term; the negotiation of optional transfer payments in the long term; and the establishment of an independent First Nations Auditor General. ("Honouring Our Ancenstors by Trailblazing a Path to the Future: Interim Report of the Joint Advisory Committee on Fiscal Relations - for Engagement Purposes” 2019, 6-8)

Despite these early commitments, federal government critics argue that systemic policy change will depend on establishing shared definitions of reconciliation, self-determination, and success. Without this common understanding, Indigenous and settler governments will continue to have diverging goals, making the task of cooperative federalism more difficult. (King 2020c, 
3) The ongoing COVID-19 pandemic has only further exposed existing inequities in the CrownIndigenous relationship, with capacity in many Indigenous communities being stretched to the breaking point. Starblanket and Hunt argue that the pandemic should not be used as a reason to ignore Indigenous sovereignty in the name of emergency management. The Crown must cooperate and co-manage with affected communities and renew ignored treaty relationships. (Starblanket and Hunt 2020, 9, 17)

\section{G. Key Lessons from the Ontario Experience}

Given all that has been discussed in this chapter, what can be learned from the way that jurisprudence on the duty to consult and accommodate is being implemented by Ontario? The Ipperwash inquiry reinforced the view that treaties are living documents with the full force of Canadian law, (Government of Ontario 2007, 80-81) and enjoy mutual recognition by both settler and Indigenous societies. (Scott and Boisselle 2019, 41) Indigenous peoples are therefore more than stakeholders for government policy, they are rights-holders, ("First Nation and Metis Consultation Policy Framework” 2010, 3; Kapyrka 2018; 2021; see also Ariss, Fraser, and Somani 2017, 17) and Ontario's policy development process needs to reflect that.

Renewing the Crown-Indigenous relationship will require shared understandings of the terms upon which such institutions are built. (McCurry 2020, 406) For instance, Indigenous communities will not have full recognition of their inherent rights so long as the Province unilaterally assesses rights impacts, and the Crown alone determines the scope of consultation. McCurry posits that public servants working with Section 35 rights should ask themselves 3 key questions: (1) does the policy framework accommodate co-existing sovereignties; (2) are there shared measures of success for both Indigenous and settler governments; and (3) is there a strategy for a long-term transition to reconciliation? (McCurry 2020, 408) As applied to 
consultation, this means that all parties should "know the 'rules of the game' and what to expect in the consultation process.” (Land 2014, 10)

How these questions are answered will vary according to each ministry's mandate and policy context, and IAO's current umbrella policy does not have the necessary granularity to be easily navigable to line ministry project teams, which in practice means that the duty to consult and accommodate is a check mark in the policy process rather than a substantive partnership. IAO has developed useful flow charts for its own land claim negotiation processes (see Appendix C), but similar documents should be co-developed in other ministries according to their mandates and in partnership with affected Indigenous rights-holders and interest groups.

First Nations are not necessarily anti-development. They simply wish to ensure the longterm vitality of their communities, hold inherent rights to share in the wealth drawn from shared territory, and indeed to participate in that wealth creation as full partners. (see Kapyrka 2018; Coates 2020) As McCurry puts it, "That does not exclude or undermine Canadian sovereignty, but it means sharing power." (McCurry 2017, 6) If Ontario continues to forge ahead with its unilateral approach to decision-making, then it will continue to fight the issue in court, and potentially pay millions of dollars in compensation to private proponents whose projects are caught in the crossfire. (Scott and Cutfeet 2019) Drawing from the 1999 Marshall case on Indigenous fishing rights, Scott and Boisselle argue: "if the 'common intention' of historic treaties 'that best reconciles the interests of the parties at the time they were signed' is that of sharing the land, the way to properly fill the gap [in treaty interpretation] is by mandating negotiations to delineate how this sharing will occur." (Scott and Boisselle 2019, 28 quoting R. v. Marshall (1999) 3 SCR 456 at para. 78, emphasis in original) 
As seen above, the ongoing Restoule v. Canada case on annuities under the Robinson Huron treaties is continuing to settle the issue of how a breach of fiduciary duty is shared between provincial and federal governments. (Restoule v. Canada (Attorney General) 2018; Restoule v. Canada (Attorney General) 2020; see also Wedge 2018; (former) Legal counsel, Ontario Ministry of Indigenous Relations and Reconciliation, in conversation with the author 2018) But the truth is that Ontario should already understand its obligations to Indigenous peoples. Commitments to consistent engagement with Indigenous partners has already appeared multiple times in IAO Departmental Plans. Yet these commitments have been walked back somewhat under a new Progressive Conservative administration.

The 2016-17 IAO departmental plan (then known as the Ministry of Aboriginal Affairs) listed corporate priorities such as "[w] orking with ministries and Indigenous partners to increase Indigenous voices in decision-making across government." On building stronger relationships, the Ministry committed to "bi-lateral relationship tables" to discuss policy priorities including treaty recognition. On a national scale, Ontario committed to engaging with First Ministers and national Indigenous organization through the Aboriginal Affairs Working Group. On building engagement capacity, the Ministry also committed to "provide funding support to First Nations, Métis and Indigenous organizations, enabling them to hire staff and experts to enhance their ability to build relationships with government and engage in consultation." (Government of Ontario 2016c)

The 2017-18 departmental plan of the newly rebranded Ministry of Indigenous Relations and Reconciliation identified in its mandate the need to "enhance awareness across ministries of Indigenous people, issues, priorities and provide advice on best practices for consulting and engaging with Indigenous people in diverse situations." Working in collaboration with the 
Nishnawbe Aski Nation - which represents 49 First Nation communities in Treaty 5 and Treaty 9 territory - the Ministry committed to a "Treaty Relationship Framework Agreement that supports a renewed Treaty relationship based on reconciliation and the respect and recognition for the treaties." However, this still stops short of establishing a Treaty Commission of Ontario as envisioned in the Ipperwash report. On consultation, the Ministry committed to "[c]ontinuing to lead Ontario's review of its current approaches to meeting the province's duty to consult Indigenous communities and working across government and with Indigenous partners, industry and others to explore options for enhancements." Finally, building on their support of the Aboriginal Affairs Working Group the year before, the Ministry recommitted to national engagement through the Federal, Provincial and Territorial Forum on Indigenous Issues. (Government of Ontario 2017b)

Despite the relationship-focussed language of previous years, a change in government lead to a marked shift towards natural resource development and a strong emphasis on federal responsibility in the fiduciary relationship in the 2019-20 departmental plan. Positively, the plan commits to revenue sharing, but only "from mining, forestry and aggregates to help Indigenous communities share in the benefits from resource development". IAO commits to supporting Indigenous consultation capacity through the New Relationship Fund, but again with a focus on extraction, rather than governance and quality of life issues: "Supporting $[\ldots]$ meaningful consultation and engagement with government and the private sector on land and resource matters". To the extent that quality of life issues are considered, the Ministry commits to "Providing advice relating to federal rights-related policies and legislation, and technical support in federally-led self-government discussions or negotiations regarding provincial responsibilities 
and interests." (Government of Ontario 2019) As the Ontario government's priorities currently stand, it seems federal leadership will frame the Crown's duty of honourable dealing.

Policymakers must be made aware that their decisions have tangible effects on the Indigenous peoples affected by them. (Benedict 2020) Decolonized relationships must move away from control and onerous reporting requirements and towards collaboration. (McCurry 2020, 405; see also Shepherd 2018) The provincial Crown's determination of its own consultation obligations is legally problematic, but there remains the need to assess these duties outside a courtroom. (Reddekopp 2013, 53) Acting alone, the Crown cannot accurately assess rights impacts, because the process of consultation itself often identifies new information. ("First Nation and Metis Consultation Policy Framework”2010, 12) All this means replacing unilateralism with joint decision-making processes. (Scott and Boisselle 2019, 16-17) These processes would need to be transparent and Indigenous-led, and governments will need to strengthen their capacity to co-manage them, but this would be consistent with the honour of the Crown. (McCurry 2020, 407, 409-10; Scott and Boisselle 2019, 37)

Coming on the heels of this dissertation's extensive discussion of constitutional law regarding the treaty relationship, the duty to consult and accommodate, and the honour of the Crown, this chapter ought to provide ample evidence that the legal, policy, and legislative frameworks to repair Crown-Indigenous relationships in Ontario already exist. As such, the Province's underperformance of its duties of consultation, accommodation, and honourable dealing is less a policy problem than it is an implementation problem. As seen in the interviews with practitioners, Ontario has at once a unilateral approach to consultation and rights assessment, and a decentralized regime for discharging the Crown's duties. There is too strong a distinction between rights-based consultation and interest-based engagement, and umbrella 
policies on the duty to consult and accommodate are in need of more focussed implementation guides for line ministries. Relationships with Indigenous rights-holders and interest groups need to be woven into the policy development process such that consultation is less a single step in policy implementation, and more a way of doing business across government sectors. This is what sharing power entails. The following chapter will review the main arguments which lead to this conclusion, discuss a few lessons that public servants can apply to their work, and explore avenues for future research.

\section{$\underline{\text { References }}$}

"Aboriginal Consultation Guide for Preparing a Renewable Energy Approval (REA)." 2016. Ontario Ministry of the Environment, Conservation and Parks. https://www.ontario.ca/page/aboriginal-consultation-guide-preparingrenewable-energy-approval-rea.

“Aboriginal Consultation Policy.” 2007. Ontario Energy Board. https://www.oeb.ca/documents/cases/acp_paper_20070618.pdf.

Administrator, Windigo First Nations Council, in conversation with the author. 2020.

Alcantara, Christopher, and Zachary Spicer. 2015. "Learning from the Kelowna Accord." Policy Options, August, 95-97.

Anishinabek Nation. 2008. “Anishinabek/Ontario Resource Management Council 2007-2008 Annual Report." http://www.anishinabek.ca/wp-content/uploads/2016/07/Report-2008.pdf.

Anishinabek/Ontario Resource Management Council. 2003. "Reaching Effective Consultation." Union of Ontario Indians. http://caid.ca/AnishinaabekConPol2003.pdf.

Ariss, Rachel, Clara MacCallum Fraser, and Diba Nazneen Somani. 2017. "Crown Policies on the Duty to Consult and Accommodate: Towards Reconciliation?" McGill Journal of Sustainable Development Law 14 (1): 3-55.

Assembly of First Nations. 2018. "Canada's Proposed Recognition and Implementation of Indigenous Rights Framework: Issues Summary.” Assembly of First Nations.

“Assembly of First Nations - Canada Memorandum of Understanding on Joint Priorities." 2017. Assembly of First Nations. https://www.afn.ca/uploads/files/canada-afn-mou-final-eng.pdf.

Association of Municipalities of Ontario. 2019. "Municipal Governments and the Crown's 'Duty to Consult."” https://www.amo.on.ca/AMO-PDFs/Reports/2019/AMO-Discussion-Paper-Municipal-Governments-and-the.aspx.

Bellefeuille, Fred. 2020. Legal Director, Anishinabek Nation, in conversation with the author.

Benedict, Abram. 2020. Grand Chief, Mohawk Council of Akwesasne, in conversation with the author. 
Bigelow, Donna. 2018. Team Leader, Policy and Relationships Office, Ontario Ministry of Transportation, in conversation with the author.

Borrows, John. 1997. "Frozen Rights in Canada: Constitutional Interpretation and the Trickster." American Indian Law Review 22 (1): 37-64.

2017. "Challenging Historical Frameworks: Aboriginal Rights, The Trickster, and Originalism." The Canadian Historical Review 98 (1): 114-35.

Burrows, Rick. 2015. "Final Ipperwash Settlement Agreement Ratified.” Blackburn News, September 19, 2015. https://blackburnnews.com/sarnia/sarnia-news/2015/09/19/final-settlement-agreement-ratified-by-kettle-and-stonypoint-first-nation/.

Canada NewsWire. 2008. "NAN Suspends Northern Table until KI Leadership Released," April 3, 2008. http://kilands.org/2008/04/03/nan-suspends-northern-table-until-ki-leadership-released/.

"Canada, Ontario, and Chippewas of Kettle \& Stony Point First Nation Announce Addition of Lands to Their Reserve." 2020. Ontario Ministry of Indigenous Affairs. https://news.ontario.ca/en/release/58291/canada-ontarioand-chippewas-of-kettle-stony-point-first-nation-announce-addition-of-lands-to-their.

CBC News. 2019. "Ford's Senior Officials Hoped to Keep Mandate Letters Away from Public View 'as Long as Possible,"” August 22, 2019. https://www.cbc.ca/news/canada/toronto/ford-s-senior-officials-hoped-to-keepmandate-letters-away-from-public-view-as-long-as-possible-1.5255593.

"Changes on the Horizon: 2017 Long-Term Energy Plan Discussion Guide." 2017. Ontario Ministry of Energy. https://www.ontario.ca/document/2017-long-term-energy-plan-discussion-guide/changes-horizon\#section-6.

Coates, Kenneth. 2020. "How Far We've Come: Indigenous Engagement with the Canadian Energy Economy." Macdonald-Laurier Institute. https://macdonaldlaurier.ca/files/pdf/20201727_Energy\%20Indigenous_Coates_PAPER_FWeb.pdf.

"Consultation in Ontario's Environmental Assessment Process." 2014. Ontario Ministry of the Environment, Conservation and Parks. https://www.ontario.ca/page/consultation-ontarios-environmental-assessment-process.

"Corporate Indigenous Policy." 2020. Independent Electricity System Operator. https://www.ieso.ca/en/GetInvolved/Indigenous-Relations/Corporate-Indigenous-Policy.

Department of Justice Canada. 2018. “The Attorney General of Canada's Directive on Civil Litigation Involving Indigenous Peoples.” https://www.justice.gc.ca/eng/csj-sjc/ijr-dja/dclip-dlcpa/litigation-litiges.pdf.

“Deputy Minister Committees: Committee Mandates and Membership." 2020. Privy Council Office. https://www.canada.ca/en/privy-council/programs/appointments/senior-public-service/deputy-ministercommittees.html.

Director, Ontario Ministry of Indigenous Affairs, in conversation with the author. 2018a. $2018 b$.

Dorries, Heather. 2012. "Rejecting the 'False Choice': Foregrounding Indigenous Sovereignty in Planning Theory and Practice." PhD, University of Toronto.

https://tspace.library.utoronto.ca/bitstream/1807/65468/1/Dorries_Heather_J_201206_PhD_thesis.pdf.

"Draft Guidelines for Ministries on Consultation with Aboriginal Peoples Related to Aboriginal Rights and Treaty Rights.” 2015. Ontario Ministry of Indigenous Affairs. https://www.ontario.ca/page/draft-guidelines-ministriesconsultation-aboriginal-peoples-related-aboriginal-rights-and-treaty. 
Dubinski, Kate. 2020. "25 Years after His Death, Dudley George's Fight for the Land Continues." CBC News, September 6, 2020. https://www.cbc.ca/news/canada/london/dudley-george-kettle-stony-point-25-anniversary1.5708055 .

"Duty to Consult with Aboriginal Peoples in Ontario: Information on Ontario's Duty to Consult Aboriginal Peoples." 2013. Ontario Ministry of Indigenous Affairs. https://www.ontario.ca/page/duty-consult-aboriginalpeoples-ontario.

"First Nation and Metis Consultation Policy Framework." 2010. Government of Saskatchewan. https://www.saskatchewan.ca/residents/first-nations-citizens/duty-to-consult-first-nations-and-metis-communities.

(former) Acting Manager, Ontario Ministry of Energy, in conversation with the author. 2018.

(former) Legal counsel, Ontario Ministry of Indigenous Relations and Reconciliation, in conversation with the author. 2018.

(former) Policy Advisor, Ontario Ministry of Natural Resources and Forestry, in conversation with the author. 2020.

"Funding for Indigenous Economic Development." 2014. Ontario Ministry of Indigenous Affairs. https://www.ontario.ca/page/funding-indigenous-economic-development.

Government of Ontario. 1998. Electricity Act, 1998. S.O. 1998, c.15. https://www.ontario.ca/laws/statute/98e15.

- 2007. "Report of the Ipperwash Inquiry, Volume 4."

https://www.attorneygeneral.jus.gov.on.ca/inquiries/ipperwash/report/vol_4/pdf/E_Vol_4_Full.pdf.

_.2009a. An Act to Amend the Mining Act. SO 2009, c. 21 - Bill 173.

https://www.ontario.ca/laws/statute/S09021.

. 2009b. Green Energy Act. S.O. 2009, c.12. https://www.ontario.ca/laws/statute/09g12.

—. 2010. Far North Act. S.O. 2010, c.18. https://www.ontario.ca/laws/statute/10f18.

_. 2016a. "Mandate Letter Progress: Aboriginal Affairs." https://www.ontario.ca/page/mandate-letterprogress-aboriginal-affairs.

—. 2016b. "Published Plans and Annual Reports 2016-2017: Ministry of Aboriginal Affairs."

https://www.ontario.ca/page/published-plan-and-annual-report-ministry-of-aboriginal-affairs.

2017a. Child, Youth and Family Services Act. S.O. 2017, c.14. https://www.ontario.ca/laws/statute/17c14.

. 2017b. "Published Plans and Annual Reports 2017-2018: Ministry of Indigenous Relations and

Reconciliation." https://www.ontario.ca/page/published-plans-and-annual-reports-2017-2018-ministry-indigenousrelations-and-reconciliation.

_ 2019. "Published Plans and Annual Reports 2019-2020: Ministry of Indigenous Affairs."

https://www.ontario.ca/page/published-plans-and-annual-reports-2019-2020-ministry-indigenous-affairs.

- 2020. Security from Trespass and Protecting Food Safety Act. S.O. 2020, c.9.

https://www.ontario.ca/laws/statute/20s09.

Gray, Bryn. 2016. "Building Relationships and Advancing Reconciliation through Meaningful Consultation.” Indigenous and Northern Affairs Canada. https://www.rcaanc-cirnac.gc.ca/eng/1498765671013/1609421492929.

Gray, Tim. 2020. "You May Have Never Heard of a Minister's Zoning Order and That Used to Be Ok - but Not Anymore." Environmental Defence. https:/environmentaldefence.ca/2020/08/28/may-never-heard-ministerszoning-order-used-ok-not-anymore/.

Haida Nation v. British Columbia (Minister of Forests). 2004 [2004] 3 SCR 511. Supreme Court of Canada. 
"Honouring Our Ancenstors by Trailblazing a Path to the Future: Interim Report of the Joint Advisory Committee on Fiscal Relations - for Engagement Purposes." 2019. Indigenous Services Canada. https://www.sacisc.gc.ca/eng/1561371591558/1561371616958.

Hunter, David, Nalin Sahni, and George McKibbon. 2012. "A New Paradigm for Aboriginal Consultation in Ontario.” Ontario Bar Association. http://www.oba.org/en/pdf/sec_news_abo_dec12_par_hun.pdf.

"Indigenous Conservation Programming: A New Approach - Report on Energy Conservation for First Nations and Métis in Ontario." 2018. Independent Electricity System Operator. https://www.ieso.ca/en/Get-Involved/IndigenousRelations/Overview.

“Inuit Nunangat Declaration on Inuit-Crown Partnership.” 2017. Inuit Tapiriit Kanatami. https://www.itk.ca/wpcontent/uploads/2017/02/English-Inuit-Nunangat-Declaration.pdf.

Johnson, Rhiannon. 2019. "Ontario Budget's Cuts to Indigenous Affairs a Setback for Reconciliation, Says Carolyn Bennett." CBC News, April 12, 2019. https://www.cbc.ca/news/indigenous/ontario-budget-indigenous-affairs-cut1.5096723 .

Kapyrka, Julie. 2018. “The Space Between: The Benefits of a Pre-Engagement Consultation Model.” Public Sector Digest, October 2018.

2021. Consultation Liaison, Curve Lake First Nation, in conversation with the author.

King, Hayden. 2018. “Canada’s Indigenous Rights Framework: A (Bad) Proposal Emerges.” Policy Brief, September 19, 2018.

_ 2020a. "The Rise Of The Anishinabek Nation: Self-Government For The Status Quo?" Yellowhead Institute, Ryerson University. https://yellowheadinstitute.org/2020/01/15/the-rise-of-the-anishinabek-nation/.

—. 2020b. "The Rise Of The Anishinabek Nation, Part II: The Fiscal Agreement.” Yellowhead Institute, Ryerson University. https://yellowheadinstitute.org/2020/02/06/the-rise-of-the-anishinabek-nation-part-ii-fiscalagreement/.

2020c. “CIRN-ACK! Leaked Government Document Outlines The Indian Department's 'Indigenous Agenda' And 'Accomplishments' For 2019-2020.” Yellowhead Institute, Ryerson University. https://yellowheadinstitute.org/2020/08/11/cirn-ack-leaked-government-document-outlines-the-indian-departmentsindigenous-agenda-and-accomplishments-for-2019-2020/.

Kohoko, Dan. 2020. Councillor, Algonquins of Pikwakanagan First Nation, in conversation with the author.

Land, Lorraine. 2014. "Creating the Perfect Storm for Conflicts Over Aboriginal Rights: Critical New Devlopments in the Law of Aboriginal Consultation.” Olthuis Kleer Townshend LLP. http://www.oktlaw.com/wpcontent/uploads/2016/10/lylPerfectStorm.pdf.

Laskaris, Sam. 2020. "First Nation Chiefs Content with Pandemic Communications from Ontario Government." Windspeaker, July 16, 2020. https://windspeaker.com/news/windspeaker-news/first-nation-chiefs-contentpandemic-communications-ontario-government.

Lysyk, Bonnie. 2020. "Value-for-Money Audit: Indigenous Affairs in Ontario." Office of Auditor General of Ontario. https://www.auditor.on.ca/en/content/annualreports/arreports/en20/20VFM_04indigenous.pdf.

Madden, Jason, and Alexandria Winterburn. 2020. "Implementing the MNO Self Government Agreement." Presented at the Provisional Council of the Metis Nation of Ontario, July 26.

http://www.metisnation.org/media/1365497/2020-07-26-pst-presentation-to-pcmno-re-mgrsa-implementation.pdf.

Manager, Ontario Ministry of Health, in conversation with the author. 2018.

McCurry, Pamela. 2017. "Concept Paper 1: Critical Conversation on Reconciliation.” 
. 2020. "Section 35 Legal Framework: Implications for Evaluation." Canadian Journal of Program Evaluation 34 (3): 400-412.

McIntosh, Emma. 2020a. "Group Representing 133 First Nations Backs Legal Challenge of Ford's Weakening of Environmental Assessments.” National Observer, August 28, 2020.

https://www.nationalobserver.com/2020/08/28/news/coalition-133-first-nations-planning-legal-challenge-fords-bill197?utm_source $=$ National + Observer\&utm_campaign $=\mathrm{d} 3041972 \mathrm{fe}-$

EMAIL_CAMPAIGN_2020_08_28_12_43\&utm_medium=email\&utm_term=0_cacd0f141f-d3041972fe254436625 .

- 2020b. "Three First Nations File Suit against Ford Government over Lack of Consultation on Forestry." National Observer, September 22, 2020. https://www.nationalobserver.com/2020/09/22/news/three-first-nationsfile-suit-against-ford-government-over-lack-consultation.

2020c. "Auditor General Issues Scathing Rebuke of Ford Government's Environmental Policies." National Observer, November 18, 2020. https://www.nationalobserver.com/2020/11/17/news/auditor-general-rebuke-fordgovernment-environmental-policies.

Mikisew Cree First Nation v. Canada (Minister of Canadian Heritage). 2005. Supreme Court of Canada.

Ministry of Indigenous Relations and Reconciliation. 2017. "One-Year Progress Report - The Journey Together: Ontario's Commitment to Reconciliation with Indigenous Peoples."

https://files.ontario.ca/progress_report1_en_web.pdf.

MNRF, Far North Branch. 2015a. "Preparing the Far North Land Use Strategy: An Update and Overview of Path Forward." Presented at the Northern Ontario First Nations Environmental Conference 2015.

https://www.nofnec.ca/PDF/2015/Values_Protection_Far_North_Strategy.pdf.

. 2015b. "Far North Land Use Strategy: A Draft." Ontario Ministry of Natural Resources and Forestry. https://www.ossga.com/multimedia/0/draft_far_north_strategy_2015_09_29.pdf.

"Modernizing Ontario's Environmental Assessment Program." 2019. Ontario Ministry of the Environment, Conservation and Parks. https://prod-environmental-registry.s3.amazonaws.com/2019-

04/EA\%20Discussion\%20Paper.pdf.

Munson, James. 2017. "Duty to Consult Seen by Some as 'Dismal Failure': Report.” IPolitics, June 30, 2017. https://ipolitics.ca/2017/06/30/duty-to-consult-seen-by-some-as-dismal-failure-says-report/.

Narine, Shari. 2020. "What Happened to the Treaty Commission of Ontario after Ipperwash Inquiry Recommendation?" Windspeaker, September 3, 2020. https://windspeaker.com/index.php/news/windspeakernews/what-happened-treaty-commission-ontario-after-ipperwash-inquiry.

North Bay Nugget. 2020. "More Votes Scheduled on Anishinabek Nation Governance Agreement," March 6, 2020. https://www.nugget.ca/news/local-news/more-votes-scheduled-on-anishinabek-nation-governance-agreement.

"Ontario and Anishinabek Nation Renew Commitments on Natural Resource Management." 2016. Ontario Ministry of Natural Resources and Forestry. https://news.ontario.ca/en/release/36219/ontario-and-anishinabek-nation-renewcommitments-on-natural-resource-management.

"Ontario Commemorates 25th Anniversary of Ipperwash Park Tragedy." 2020. Ontario Ministry of Indigenous Affairs. https://news.ontario.ca/en/statement/58272/ontario-commemorates-25th-anniversary-of-ipperwash-parktragedy.

Ontario Ministry of Northern Development and Mines. 2012. "MNDM Policy: Consultation and Arrangements with Aboriginal Communities at Early Exploration." Government of Ontario.

https://web.archive.org/web/20190711204417/https://www.mndm.gov.on.ca/sites/default/files/aboriginal_exploratio n_consultation_policy.pdf. 
“Ontario’s Long-Term Energy Plan 2017: Delivering Fairness and Choice.” 2017. Ontario Ministry of Energy. https://files.ontario.ca/books/ltep2017_0.pdf.

“Ontario's New Approach to Aboriginal Affairs.” 2005. Ontario Native Affairs Secretariat. http://docs.files.ontario.ca/documents/222/6-maa-new-approach-to-aboriginal-affairs.pdf.

"Political Accord Between First Nations and the Government of Ontario." 2015. Ontario Ministry of Indigenous Affairs. https://news.ontario.ca/en/backgrounder/33998/political-accord-between-first-nations-and-the-governmentof-ontario.

"Principles Respecting the Government of Canada's Relationship with Indigenous Peoples." 2018. Department of Justice Canada. https://www.justice.gc.ca/eng/csj-sjc/principles.pdf.

Reddekopp, Neil. 2013. "Theory and Practice in the Government of Alberta's Consultation Policy." Constitutional Forum 22 (1): 47-62.

Reid, Randy. 2018. (former) Director, Negotiations Branch, Ontario Ministry of Indigenous Relations and Reconciliation, in conversation with the author.

Restoule v. Canada (Attorney General). 2018. Ontario Superior Court of Justice.

-2020. Ontario Superior Court of Justice.

Review of Laws and Policies Secretariat. 2017. "Co-Chair Meeting Scenario Note with Speaking Points, Deputy Ministers’ Task Force on Reconciliation.” Briefing Document. Ottawa, ON: Department of Justice Canada.

Rice, Waubgeshig. 2018. "Ontario First Nations Acquire 14 Million Shares of Hydro One.” CBC News, January 4, 2018. https://www.cbc.ca/news/indigenous/ontario-first-nations-hydro-one-shares-1.4473126.

Sabin, Jerald. 2017. "A Federation within a Federation? Devolution and Indigenous Government in the Northwest Territories.” 66. IRPP Study. Institute for Research on Public Policy.

Scott, Dayna Nadine. 2019. "Doug Ford's Repeal of the Far North Act Won't Gain the Respect of Indigenous Communities." Globe and Mail, March 25, 2019. https://www.theglobeandmail.com/opinion/article-doug-fordsrepeal-of-the-far-north-act-wont-gain-the-respect-of/.

Scott, Dayna Nadine, and Andree Boisselle. 2019. "If There Can Only Be 'One Law', It Must Be Treaty Law. Learning from Kanawayandan D'aaki," Articles \& Book Chapters, . https://digitalcommons.osgoode.yorku.ca/scholarly_works/2745.

Scott, Dayna Nadine, and John Cutfeet. 2019. "After the Far North Act: Indigenous Jurisdiction In Ontario's Far North.” Yellowhead Institute, Ryerson University. https://yellowheadinstitute.org/2019/07/09/after-the-far-northact/.

Shepherd, Robert. 2018. "Indigenous Peoples and the Reconciliation Agenda: Funding, Accountability and Risk." In The Handbook of Canadian Public Administration, edited by Christopher Dunn, 3rd ed., 246-68. Toronto: Oxford University Press.

Starblanket, Gina, and Dallas Hunt. 2020. "COVID-19, The Numbered Treaties \& The Politics of Life." Yellowhead Institute, Ryerson University. https://yellowheadinstitute.org/wp-content/uploads/2020/06/yi-special-report-covid19and-treaties.pdf.

Sterling, Lori, and Peter Landmann. 2009. "The Duty to Consult Aboriginal Peoples - Government Approaches to Unresolved Issues.” Canadian Bar Association. www.cba.org/cba/cle/PDF/Constit09_Sterling_paper.pdf.

Stonechild, Blair. 2018. "Office of the Treaty Commissioner." In Indigenous Saskatchewan Encyclopedia. University of Regina Press. https://teaching.usask.ca/indigenoussk/import/office_of_the_treaty_commissioner.php. 
“Sustainable Forest Management Policy.” 2016. Algonquin Forest Authority. http://algonquinforestry.on.ca/wpcontent/uploads/SFM-Policy-Final_Nov-2016.pdf.

Taku River Tlingit First Nation v. British Columbia (Project Assessment Director). 2004 [2004] 3 SCR 550. Supreme Court of Canada.

“The Journey Together: Ontario's Commitment to Reconciliation with Indigenous Peoples.” 2016. Ontario Ministry of Indigenous Affairs. https://www.ontario.ca/page/journey-together-ontarios-commitment-reconciliationindigenous-peoples.

Wedge, Grant. 2018. Assistant Deputy Minister, Negotiations and Reconciliation Division, Ontario Ministry of Indigenous Affairs, in conversation with the author.

Whetung, Emily. 2020. Chief, Curve Lake First Nation, in conversation with the author.

White, Erik. 2020. "Anishinabek Nation Says 8 of 14 First Nations Vote Yes on Governance Agreement, but Turnout Still in Question.” CBC News, March 4, 2020. https://www.cbc.ca/news/canada/sudbury/anishinabekgovernance-vote-first-nations-1.5484886. 


\section{Chapter 7: Looking Forward, Looking Back}

When the Royal Commission on Aboriginal Peoples delivered its report in 1996, the first of six volumes was entitled Looking Forward, Looking Back. It examined the histories of Indigenous North American societies before European contact and traced their interaction with the colonists from trading relationships to treaty relationships, through Confederation, assimilation, displacement, and a new era of resilience. In reviewing this history and outlining the four principles of renewed relationship - recognition, respect, responsibility and sharing - the Commission asked its readers to reconsider the foundational compact between peoples at the root of Confederation. Settler governments have ignored these foundations for generations, choosing instead to focus on the compact between the provincial and federal governments, or English and French Canada. While settler governments were engaged in reforming these relationships in the era of constitutional reform lasting from the mid-seventies to the mid-nineties, Indigenous resilience and activism also secured the addition of Section 35 as a reaffirmation of the original Crown-Indigenous covenant. That key act of resistance against erasure changed the rules of the constitutional game, and reinvigorated Indigenous legal orders that had persisted in the face of colonial policy.

Both historic and modern treaties are thus protected under constitutional law and provide a roadmap for the terms of the Crown-Indigenous relationship, but require periodic renewal as any political accord must. This Indigenous order of government exists on a plane with the federal and provincial orders - a division with which settler governments ought to have familiarity, but whose full recognition has proven difficult for governments to understand, leading them to rely on jurists for clarification. Repeated attempts to further define "existing" Aboriginal rights under 
Section 35 of the Constitution Act, 1982 failed, but this lack of precision has left an opportunity for Indigenous activists to present their perspectives before the courts. The Supreme Court of Canada, as the interpretive body for constitutional law, is empowered to fill this "box of rights," and in recent decades it has produced successive judgments making Indigenous understandings increasingly clear in common law.

This final chapter reviews key points in this dissertation about how a specific area of Section 35 jurisprudence on the duty to consult and accommodate captures a larger truth about the Crown-Indigenous relationship. Settler governments are required to consult because Indigenous governments hold inherent political legitimacy. Indigenous polities predate colonization, and Crown sovereignty remains "asserted" or "de facto" until treaties outline the terms of Crown sovereignty through Indigenous consent. (see Starblanket 2019) Treaty law is the source of Crown sovereignty in Indigenous territories, which means that Indigenous nations are the fundamental source of legal legitimacy in North America. The Crown must act honourably in all its dealings with Indigenous peoples, because the failure to do so erodes its own legal foundation.

This review of Canadian federalism, duty to consult jurisprudence, and Ontario policy and legislation will finally allow the research question to be answered. I find that although judicial discourse has made its way into law and policy on Crown-Indigenous consultation, the changes wrought are not significant enough to have brought systemic change to Ontario's role in cooperative federalism. In my view, this is largely an implementation challenge, and speaks to the great institutional inertia of colonial policy. There are important signs of progress on the horizon, but steering the settler ship of state towards reconciliation will take time and sustained effort. Some of the key hurdles for Ontario will be discussed, including unilateral decision- 
making, mandate-specific implementation, capacity funding, and institutional buy-in. Finally, this chapter will close with a few lessons that public servants can use to bridge the policy gap in a relational understanding of treaties, and avenues for future research will be explored.

\section{A. Chapter Review}

The opening chapter of this dissertation placed this research in the broader context of Canada's reconciliation project. Not only are the concepts described herein a response to the TRC Calls to Action which the federal government has committed to implementing particularly Call to Action 57 on the education of public servants - but more importantly, they are matters of Canadian constitutional law. Aboriginal and treaty rights are essential building blocks of Canadian federalism and legal pluralism. Denying these rights will only cost federal and provincial governments time and money fighting court battles over settled matters of constitutional law, not to mention responding to direct action by Indigenous communities defending their interests in the absence of consultation. Honourable negotiation, therefore, is the path of least resistance, as well as the right thing to do.

I posit in the first chapter that the failure of settler governments to recognize inherent Indigenous sovereignty is the main stumbling block in reconciling the Crown-Indigenous relationship. Despite divergent understandings of reconciliation, this dissertation grounds that understanding in the 4 Principles of a Renewed Relationship outlined by the Royal Commission on Aboriginal Peoples, these being mutual recognition, respect, responsibility, and sharing.

Since Patriation, a principal avenue for facilitating the settler recognition of Indigenous sovereignty has been common law. The instrumental use of precedent in common law makes its

principles tremendously adaptable, such that Indigenous and settler understandings of treaty law 
can be bridged and enjoy mutual recognition by their respective societies. This adaptability, combined with the broad language of Section 35, presents the possibility of reconciling Indigenous and non-Indigenous legal orders.

The second chapter in this dissertation delved into theories of federalism to gain a greater understanding of where treaty law falls in the scholarship on Confederation. Three main theories were offered: "treaty federalism" from the Canadian literature, "judicial federalism" from the American literature, and my own synthesis of the two, "judicial treaty federalism". Treaty federalism, building upon the work of scholars such as Sakèj Henderson and Kiera Ladner, recalls the early days of colonization when Indigenous peoples were the dominant political force in North America. In the wake of colonial wars with the French, the British Crown signed treaties with Indigenous nations to secure their military allegiance and the continuation of valuable trade relationships. In particular, the Royal Proclamation of 1763 and the companion Treaty of Niagara in 1764 cemented the Crown-Indigenous relationship in a quasi-federal structure where each sovereign nation recognized each other's sphere of jurisdiction while committing to shared territory. Under treaty federalism, Indigenous nations are allies and partners of the Crown, but they are not subjects of the Crown except where their sovereignty is specifically ceded to the Crown though treaty.

Judicial federalism is built on the work of former US Supreme Court Justice William Brennan. In Brennan's reading of the $14^{\text {th }}$ Amendment to the US Constitution, neither federal nor state actors could infringe upon the civil liberties of US citizens. Given that US states have their own constitutions, this meant that rights available under state law could not be abrogated by the federal government. This created a school of thought in American legal scholarship wherein 
State Supreme Courts could rule on civil rights that were constitutional in nature by virtue of the $14^{\text {th }}$ Amendment, but existed outside of the federal constitutional document.

My own theory of federalism amalgamates these two approaches. Judicial treaty federalism (JTF) argues that judges have expanded Canadian rights law using documents that are constitutional in nature, but like state constitutions, exist outside the federal constitutional document. Since Canadian provinces do not have constitutions of their own, the closest analog in Canadian federalism is treaty law. Treaty rights are recognized and affirmed by Section 35 of the Constitution Act, 1982 but also have their own independent force of law, as described by treaty federalism. Judicial interpretation can bridge legal orders and articulate these sui generis principles in common law precedent. However, the extent to which these principles have actually changed the operation of Canadian federalism depends on how they are implemented by policymakers. The duty to consult and accommodate is one prominent application of these rights since, as described above, the duty incorporates the recognition of Indigenous political legitimacy and imposes constitutional limitations on state action.

Chapter 3 cast an eye back to Canada's constitutional history to find other instances where judicial interpretation of constitutional law has changed the operation of federalism. The so-called "compact theory of Confederation" described the interpretation of the 1867 British North America Act by the Judicial Committee of the Privy Council (JCPC), which until 1949 was Canada's highest court of appeal. Through successive judgments in the late $19^{\text {th }}$ and early $20^{\text {th }}$ century, the JCPC - and, in particular, justices Lord Watson and Viscount Haldane - read Sections 91 and 92 of the BNA Act not as examples of federal and provincial powers, but rather as an enumeration. This transformed Canada from a country in which there was an ascendant federal government to one in which there were co-equal orders of federal and provincial 
government, each of which was supreme in its own areas of jurisdiction; an interpretation which remains to this day. Compact theory was interpreted in different contexts either as a "provincial compact" in which the constitution resembled a treaty between provincial governments, or a "national compact" between English and French Canada, and their respective common law and civil law legal orders. Compact theory is useful in the study of the Crown-Indigenous relationship, because it shows that Canada has already adapted to legal pluralism and co-equal orders of government, but once again the settler recognition of Indigenous sovereignty has proven a hurdle. The recognition of inherent Indigenous rights widens the circle of Canada's existing federal compact, and acknowledges the legal and political legitimacy that Indigenous nations hold.

Indigenous people themselves pushed aggressively for this recognition, and the closing pages of the chapter reviews the constitutional conferences of the 1980s and early 1990s, where Indigenous advocates voiced their demands through negotiation, litigation, and activism. These efforts secured the addition of Section 35 to the Constitution Act, 1982, and although efforts to further define the nature of these rights failed in later conferences, the stage was set for the recognition of Aboriginal and treaty rights in constitutional law.

Chapters 4 and 5 explored the legal elements of this constitutional recognition using selected jurisprudence on the duty to consult and accommodate. The Haida Nation and Taku River outlined the content of the duty to consult and accommodate, declaring that the duty arose from the honour of the Crown and the reconciliation project intended in Section 35. Mikisew Cree applied the duty to consult and accommodate to historic treaties, and Little Salmon/Carmacks did the same for modern treaties. Both Little Salmon/Carmacks and Grassy Narrows affirmed that provincial and territorial governments owed an equal duty to consult and 
accommodate as their federal counterparts, meaning that it is the Crown itself which owes the duty, irrespective of which government wears it. Finally, Tsilhqot'in affirmed the continuity of Aboriginal land title on unceded lands, opening the door to a standard of Indigenous consent, rather than simple consultation.

All these cases interpreted the duty to consult and accommodate through the lens of treaty relationships, whether historic or modern treaties, or the specific absence of treaties on unceded territory. Taken together, the Court has provided certain minimum standards for the content of the duty to consult, but it has refrained from describing exact expectations for a number of reasons. Judicial decisions must rule on a specific question before the Court, and so the application of the duty to consult and accommodate is assessed on a case-by-case basis. This is appropriate, given Indigenous peoples themselves have varied histories and treaty relationships with the Crown. Fundamentally though, Crown-Indigenous partnerships must not be the subject of legal ruling, but rather political negotiation in the spirit of mutual recognition, respect, and sharing.

It is this political area that the penultimate chapter of this dissertation sought to explore. Chapter 6 provided an overview of Ontario legislation and policy guidelines which frame the implementation of the duty to consult and accommodate. With the possible exception of the 2017 Child, Youth and Family Services Act, Ontario legislation jealously guards ministerial discretion, and rarely weaves Indigenous consultation into the decisions taken by the relevant Minister. That said, the explicit acknowledgement of the duty to consult should temper the unilateral interpretation of legislation. Furthermore, Ontario signed an Accord with the Chiefs of Ontario in 2015 which explicitly recognizes the Indigenous right to self-government as an inherent right. 
The Province's approach to law and policy implementation should me made consistent with this affirmation.

Broad umbrella policies regarding implementation of the duty to consult and accommodate are helpful general guides, but because Aboriginal and treaty rights apply to multiple ministry mandates, more mandate-specific implementation guides are needed so that ministerial staff understand how the implementation of the duty to consult, and indeed the recognition of Indigenous rights more broadly, applies to their policy context. Such guides must be co-developed with Indigenous partners since Indigenous governments, as self-determining political entities, hold the right to define the terms of their own recognition by the settler state. Interviews with public servants and First Nation leaders reinforced this conclusion, and exposed other issues related to the (occasionally false) distinction between rights-based consultation and interest-based engagement, the sharing of information both within government and with Indigenous rights-holders, and the definition of "procedural aspects" of the duty to consult which may fairly be delegated to private sector proponents. In an effort to place Ontario within a larger federal context, the chapter closed with a brief examination of approaches to consultation and inherent Indigenous rights in certain other provinces, territories, and the federal government.

\section{B. Answering the Research Question}

At the outset of this dissertation, I asked a two-pronged research question: Is judicial discourse on the duty to consult and accommodate evident in Ontario's First Nation consultation policies? If so, have any systemic changes occurred as a result? Given the evidence presented in this dissertation, the answer to the first question, at least, is yes. 
As seen in the previous chapter, the opening passages of legislation such as the Mining Act and the Electricity Act, which frame the work of key land and resource ministries, expressly declares that these laws are to be interpreted in a manner consistent with the duty to consult, and Section 35 more generally. Amendments in 2016 to the latter Act also impose some restrictions on ministerial discretion, requiring the Minister both to consult with Indigenous peoples on a long-term energy plan, and to demonstrably integrate that consultation into the creation of a plan. These restrictions are limited in scope, but nevertheless they make certain actions of the Ontario Crown contingent upon consultation and the respect for Aboriginal and treaty rights. Codeveloped legislation such as the 2017 Child, Youth and Family Services Act contain even broader restrictions for Crown agencies.

The 2015 guidelines on the duty to consult issued by the Ministry of Indigenous Affairs to other provincial ministries naturally contains direct reference to the Supreme Court trilogy which gave rise to the duty to consult and accommodate. However, more sector-specific policy such as the 2007 consultation policy of the Ontario Energy Board, or the 2015 draft of the Far North Land Use Strategy also contain direct references to the duty to consult.

Thus, this research concludes that judicial discourse on the duty to consult and accommodate is apparent in consultation policy, but this is only half the battle. The second half of the research question asks whether any systemic changes have occurred as a result. Unfortunately, the shortest answer to that question must be "no." Nevertheless, this answer must come with some qualification.

My First Nation interviewees all indicated that the overall relationship with the provincial government has noticeably improved in the years since the Haida Nation decision in 2004. Indigenous concerns are generally treated with seriousness by the Ontario Crown (Bellefeuille 
2020), and both politicians and public servants have actively reached out to First Nation communities. (Whetung 2020) Despite this assessment, the question asks about systemic changes. To my understanding of the question, this requires evidence that the duty to consult and accommodate has been adopted by the Province as a whole-of-government strategy. This means that consultation is woven into to policy development process itself, and that Indigenous people are not treated as a rubber stamp after a policy is largely complete. The Royal Commission on Aboriginal Peoples stated some 25 years ago that the four principles of a renewed relationship mutual recognition, respect, responsibility, and sharing - could be summed up in a single concept: "Relations that embody these principles are, in the broadest sense of the word, partnerships." (Royal Commission on Aboriginal Peoples 1996a, 1:678 emphasis in original) The important work of repairing relationships has already begun at a high level, but the provincial government still faces major implementation challenges. Until consultation and partnership is simply part of the way the Province does business, then the change embedded in the twin concepts of the duty to consult and the honour of the Crown will be incomplete.

Each ministry is used to implementing its own mandate, and most have had little experience managing direct impacts to Indigenous rights. Traditionally, they have looked to Indigenous Affairs teams for guidance on how duties of honourable dealing apply to them. These teams are actively engaged in educating their colleagues, but there remain four key hurdles to comprehensive implementation of the duty to consult and accommodate.

The first hurdle is that the provincial Crown unilaterally determines the severity of impacts on Indigenous rights. It is fundamentally disrespectful to assess rights impacts without first consulting those who will face the effects of that decision. The court has declared that the duty to consult applies even to potential rights impacts, whether these rights have official 
recognition or not. If the Crown's duty of honourable dealing applies to all its relations with Indigenous peoples, then Indigenous rights-holders and interest groups must be part of the assessment process.

The second hurdle for the full implementation of the duty to consult and accommodate is that high-level policy guides are not enough in a decentralized policy landscape. Indigenous Affairs staff are not experts on the work of their line ministry colleagues, nor should they be. Indigenous Affairs should be responsible for oversight, coordination, and communication between ministries on Indigenous programs and consultations, rather than the application of inherent rights to individual policies. The high-level guidance provided to line ministries must be made navigable and applicable in sector-specific contexts. Implementation teams within each ministry whose work has an Indigenous policy lens (and that is most of them) must create consultation and accommodation guides for the specific work in their sector. This would be a useful tool for lower level and frontline staff to understand their role in implementing Indigenous rights on the ground. Knowing what the duty to consult and accommodate specifically means for their work would both empower public servants and provide broader access to government for Indigenous communities in the spirit of mutual recognition, respect, and partnership. As with rights assessment, these subject-specific consultation guides must be crafted in collaboration with Indigenous rights-holders and interest groups, and cannot be the exclusive prerogative of settler government.

The third hurdle to implementing the duty to consult and accommodate is capacity. Holistic partnership with Indigenous governments means that both Indigenous and settler consultation teams require the financial and human resources to respond in a timely way to frequent government-to-government communication. Ministries must invest in establishing in- 
house Indigenous relations teams, or build up existing ones. These teams can liaise with the central Ministry of Indigenous Affairs to develop the sector-specific implementation plans mentioned above, develop education tools to share these among ministry staff, cultivate relationships with Indigenous rights-holders and interest groups relevant to their mandate, and establish new advisory councils which would cement new institutionalized partnerships. This would leave the Ministry of Indigenous Affairs to focus its efforts on larger, multi-sector issues such as land claim negotiations and treaty relationships.

On the Indigenous side, communities and nations also need the capacity to respond to frequent government requests. There are a number of ways to free up resources for this purpose, but exact methods will need to be negotiated. The federal and provincial governments could directly fund positions through multi-year grants, some of which are already being piloted; or negotiate a system of transfer payments to Indigenous governments. Settler governments could also fund this capacity indirectly by facilitating own-source revenue for Indigenous communities. That could mean sharing a portion of resource revenues, facilitating Indigenous investment in public assets, and widening the power of Indigenous communities to levy local taxes and user fees.

The fourth and final hurdle to implementing the duty to consult and accommodate is related to the third, and that is buy-in. On a political level, public servants need the support of their Ministers to forge ahead with the work of reconciliation. In the beginning phases of rebuilding Crown-Indigenous relationships, there will be a relative paucity of institutionalized partnerships. This means that political will has to initiate the reconciliation process. Public servants are likely to keep administering broken systems if there is no support for change from their political masters. With that in mind, legislators need to understand that there is no escaping 
this issue. This research has already established in great detail the constitutional nature of Indigenous rights, and the duty to consult and accommodate as an outgrowth of that. Avoiding the engagement of Indigenous partners can only lead to re-litigating settled issues of constitutional law. This will cost the Ontario government time, money, and political capital, all for what is likely to be a losing battle. (Association of Municipalities of Ontario 2019, 6) It is in the best interest of provincial governments, whatever their political stripe, to accept that Indigenous rights are inherent rights, and to craft consultation and accommodation policy on that basis.

On the civil service side, Directors and Assistant Deputy Ministers also need to understand their leadership role in reconciliation. There is often leeway within their mandates to help or hinder the recognition of Indigenous rights. They need to educate themselves on the effects of their policy in Indigenous contexts, support working groups within their ministries in advancing the work of reconciliation, and facilitate inter-ministry communication on these issues such that the Province acts more effectively as one Crown.

\section{Does Judicial Treaty Federalism Exist?}

So much for the research question itself. What of the implications for federalism? Is there enough evidence to show that Judicial Treaty Federalism exists? The answer, I think, is a rather unsatisfactory "it depends."

This dissertation has argued throughout that the Supreme Court's interpretation of treaty relationships has allowed settler courts to consider Indigenous understandings and incorporate them into common law. (Scott and Boisselle 2019, 24) As McCurry succinctly concludes: 
The Court's careful articulation of the principles of reconciliation, the fiduciary relationship, the honour of the Crown, and the duty to consult has provided the Crown and Indigenous peoples with a range of tool to respectfully and constructively manage their relationships. Aligned with that, the Court has repeatedly encouraged principled processes of honourable negotiation over reliance on the courts to resolve differences. (McCurry 2020, 405)

The treatment of treaty relationships in duty to consult jurisprudence has shown that the Supreme Court consistently interprets Aboriginal and treaty rights as being both sui generis in their character and having the full force of constitutional law under Section 35. If strictly analyzing JTF through a legal lens, then the jurisprudence satisfies the requirements of JTF's component parts. By both acknowledging the independent character of Indigenous polities linked to the Crown through treaties, and endorsing a body of rights that exists outside the federal constitution, both treaty federalism and judicial federalism are accounted for.

However, this dissertation is a policy study. Having repeatedly endorsed honourable negotiation, as McCurry says, the Court cannot very well impose a legal solution to a political relationship. Unlike the compact theory of Confederation which preceded it, JTF has not yet produced a co-equal branch of government in an alternate sphere of jurisdiction. Indigenous polities continue to exist independently of Canadian federalism, but the unfinished work of Confederation is still very much a work in progress.

What JTF has done, on the other hand, is change the discourse around Aboriginal and treaty rights. In the opening chapter of this dissertation I spoke about both the "democratic dialogue" between courts and legislatures, (Hogg and Bushell 1997c) and the "discursive institutionalism" of political scientist Vivien Schmidt. (Schmidt 2008; 2010; 2011) The former concept describes a conversation of sorts between the judicial and legislative branches of government. Laws are upheld, reinterpreted, or struck down by courts depending on their 
consistency with constitutional principles. These judgments are met by a legislative response, and the cycle continues. Ontario legislation and policy on the duty to consult and accommodate, as explored herein, were often drafted in the wake of new legal requirements. For example, Ontario's New Approach to Aboriginal Affairs was released in 2005, just months after Haida Nation and Taku River decision. As that policy reads: "Ontario has a duty to consult Aboriginal peoples where its actions may adversely affect an established or asserted Aboriginal or treaty right. [...] Ontario is committed to meeting its duty to consult with and, where appropriate, to accommodate Aboriginal peoples." ("Ontario's New Approach to Aboriginal Affairs” 2005, 15)

This interaction also speaks to the dynamic policy change embodied in discursive institutionalism. As Schmidt describes, public discourse shapes social norms, and these norms become cemented as a "collective memory" which cyclically affects to goals of policy actors. Actors are therefore both subjects and agents of institutional change. (Schmidt 2010, 9; 2011, 52) The Supreme Court's framing of Aboriginal and treaty rights, whether as "fiduciary duties", or the Crown's "duty to consult", or the "honour of the Crown," has changed the way both Indigenous and settler governments speak about rights, and policy institutions have changed to respond to these new legal and social norms. (Ariss, Fraser, and Somani 2017, 27)

I do not mean to suggest that judicial discourse is the only vector of change in the CrownIndigenous relationship. This includes Indigenous activism, government inquiries, scholarship, and sometimes even personal conversations. With that in mind, I return to a passage from Schmidt's work arguing that discourse does not need to explain all institutional change to have influence:

Part of the reason many political scientists avoid explanations related to discourse is that it is difficult to separate it from other variables, to identify it as the independent variable. But instead of ignoring discourse because of the difficulties, 
because it might not be the cause, it is much better to ask when is discourse $a$ cause, that is, when does discourse serve to reconceptualize interests, to chart new institutional paths, and to reframe cultural norms?

For this, we need to establish what criteria to use in evaluating whether discourse has a causal influence, that is, when it is "transformative" and when it is not. [...] Factors such as timing, political salience, policy viability, and fit in terms of national values, tradition, and culture are equally important. In the realm of discursive interactions, who is speaking to whom [...] also matters. (Schmidt 2011,62 , emphasis in original)

Given the high esteem that judges hold in Canadian society, I think it is fair to say that Judicial Treaty Federalism may have yet to change Canadian federalism, but it has certainly changed both public discourse and policy responses to the existence of inherent Indigenous rights.

\section{General Rules for Effective Consultation Relationships}

Despite my call for greater precision in provincial consultation policy, I also recognize that such policies remain to be negotiated in collaboration with Indigenous partners. Unfortunately, this means that I can personally offer no greater specificity. In the preface to this dissertation, I stated that my target audience was settler public servants, the intention being to provide guidance in how to be a more effective partner in the reconciliation project. What principles, then, can be drawn from this work to guide public servants in a time before institutionalized Crown-Indigenous partnerships become the new standard? How can we bridge the policy gap in treaty interpretation while negotiations are ongoing? I offer here a few parting thoughts which I hope may be of use for public servants to act as effective partners.

Ask questions. No matter the policy area, ask if there is a potential Indigenous lens which may require special consideration in your policy project. If so, seek out the appropriate rightsholding communities or interest groups. Policies of general application are likely to have more 
general implications for Indigenous peoples, meaning that representative organizations are likely a good starting point for outreach. If the policy is local, ask what local Indigenous communities might be affected. Put simply, know who your neighbours are, and which rights might be at risk. (Kapyrka 2021) It is likely that other policy teams have conducted similar outreach, so seek guidance from colleagues and government databases on who should be contacted.

Be humble. Recognize that although your policy team may be well-versed in the particulars of your policy project, new information is likely to come to light through Indigenous consultation. Indigenous governments hold political legitimacy, and their concerns must be substantively accounted for in the resulting policy. This may include capacity funding, revenuesharing, co-management, co-development, or other shared governance measures flowing from the inherent Indigenous right to self-government which now has recognition in both Ontario and federal policy. Prepare for the possibility that your policy initiative may fail, and you may need to seek other Indigenous-led alternatives.

Be communicative. Early and regular engagement is the best course of action when fostering Crown-Indigenous relationships. This allows open communication of your Ministry's policy goals, identifies Indigenous concerns early, and incorporates this input into draft policies before work has to be undone rewriting unilateral policy. In addition to open communication with Indigenous partners, be sure to communicate with other line ministry teams. Particularly on projects which bridge multiple ministry mandates, coordinating consultations reduces the capacity commitment both for the Crown and Indigenous communities, and shortens project timelines. It also allows ministries to respond to Indigenous concerns in multiple subject areas. Finally, open communication within government allows for best practices to be easily shared and enables the government to act as one Crown. 
Don't rush. Recognize that Indigenous communities and interest groups require time to formulate a policy position. Depending on the significance of the policy, this may first require internal consultation within the affected community. Early communication also helps in this vein, as it allows for both government and Indigenous policy formulation to proceed in parallel. Recognize also that Indigenous governments have multiple responsibilities, as does any government, but they are likely managing a smaller administrative team. Where possible, act to reduce the capacity burden on Indigenous governments by coordinating consultations, or else provide support for the capacity needs you are imposing on Indigenous communities. Supporting capacity along with flexible timelines is more likely to foster productive relationships. (Ariss, Fraser, and Somani 2017, 50)

The point is choice. No matter how generous the terms of your policy or project, Indigenous peoples will not acknowledge meaningful consultation if they had no hand in crafting its substance. Indigenous nations must be allowed to choose the terms of their association with the Crown, just as they did at the signing of treaties. This still leaves room for cooperation and compromise, but remember that policy co-development incorporates the recognition of Indigenous peoples' inherent jurisdiction and the inherent right to self-government. Seeking buyin from Indigenous governments requires that Indigenous-led priorities are incorporated alongside government priorities, and that community concerns are substantively accounted for in any subsequent accommodation. (for discussion, see Dorries 2012, 157, 162-63; Ariss, Fraser, and Somani 2017, 24, 49; Kapyrka 2018) Actualizing co-development the policy process means that any resulting agreement is both in keeping with the sharing relationship outlined in treaties, and is substantially less likely to be rejected. 


\section{E. Avenues for Future Research}

In placing Ontario's consultation policies within a broader federal context, this research briefly touched upon the consultation policies of Alberta, Saskatchewan, and the Northwest Territories. Most of the scholarship on the Crown-Indigenous relationship focuses on the relationship with the federal Crown, but this research shows that areas of provincial jurisdiction have significant implications for Indigenous treaty lands and traditional territories. The empowerment of an Indigenous order of government will necessarily require coordination with provincial and territorial governments. While this research is limited to the relationship between First Nations and the Ontario Crown, there remains considerable room for similar explorations in other provinces and territories. Distinctions-based research could also explore the unique relationships between the Métis Nation or the Inuit and provincial/territorial governments.

Even with respect to Ontario First Nations there is room for further study of implementation. Notably, the rollout of the new "Knowledge Management System" to share information on ongoing consultations and Indigenous rights assertions between provincial ministries is slated for the spring of 2021.(Lysyk 2020,35-36) It will take time to establish whether this system will see widespread support by the Ontario public service, and if so, whether more information-sharing leads to more collaborative Crown-Indigenous relationships in the province.

If a deeper theoretical reading of consultation policy is being sought, there is room to analyze provincial consultation policies through other theoretical frameworks. Judicial Treaty Federalism applies the jurisprudence on Aboriginal and treaty rights to the functioning of federalism, but Ontario's consultation policy could also be analyzed through a Marxist lens, for example, to critique the link between capitalism and the failure to recognize Indigenous 
sovereignty. This is of particular relevance considering the resource extraction being contemplated in mineral-rich areas such as the "Ring of Fire" in northwestern Ontario.

Finally, while this research has limited itself to the discussion of duty to consult jurisprudence, there remain many other areas of Aboriginal and treaty law which could be analyzed through the lens of Judicial Treaty Federalism, including hunting and fishing rights, Aboriginal justice, and Aboriginal title.

\section{$\underline{\text { References }}$}

Ariss, Rachel, Clara MacCallum Fraser, and Diba Nazneen Somani. 2017. "Crown Policies on the Duty to Consult and Accommodate: Towards Reconciliation?” McGill Journal of Sustainable Development Law 14 (1): 3-55.

Association of Municipalities of Ontario. 2019. "Municipal Governments and the Crown's 'Duty to Consult."” https://www.amo.on.ca/AMO-PDFs/Reports/2019/AMO-Discussion-Paper-Municipal-Governments-and-the.aspx.

Bellefeuille, Fred. 2020. Legal Director, Anishinabek Nation, in conversation with the author.

Dorries, Heather. 2012. "Rejecting the 'False Choice': Foregrounding Indigenous Sovereignty in Planning Theory and Practice." PhD, University of Toronto.

https://tspace.library.utoronto.ca/bitstream/1807/65468/1/Dorries_Heather_J_201206_PhD_thesis.pdf.

Hogg, Peter W., and Allison A. Bushell. 1997. "The Charter Dialogue between Courts and Legislatures (Or Perhaps the Charter of Right Isn’t Such a Bad Thing After All).” Osgoode Hall Law Journal 35 (1): 75-124.

Kapyrka, Julie. 2018. “The Space Between: The Benefits of a Pre-Engagement Consultation Model.” Public Sector Digest, October 2018.

. 2021. Consultation Liaison, Curve Lake First Nation, in conversation with the author.

Lysyk, Bonnie. 2020. "Value-for-Money Audit: Indigenous Affairs in Ontario.” Office of Auditor General of Ontario. https://www.auditor.on.ca/en/content/annualreports/arreports/en20/20VFM_04indigenous.pdf.

McCurry, Pamela. 2020. "Section 35 Legal Framework: Implications for Evaluation.” Canadian Journal of Program Evaluation 34 (3): 400-412.

“Ontario’s New Approach to Aboriginal Affairs.” 2005. Ontario Native Affairs Secretariat. http:/docs.files.ontario.ca/documents/222/6-maa-new-approach-to-aboriginal-affairs.pdf.

Royal Commission on Aboriginal Peoples. 1996. Looking Forward, Looking Back. Vol. 1. 6 vols. Government of Canada.

Schmidt, Vivien. 2008. "Discursive Institutionalism: The Explanatory Power of Ideas and Discourse.” Annual Review of Political Science 11: 303-26. 
- 2010. "Taking Ideas and Discourse Seriously: Explaining Change through Discursive Institutionalism as the Fourth “New Institutionalism.”” European Political Science Review 2 (1): 1-25.

2011. "Reconciling Ideas and Institutions through Discursive Institutionalism." In Ideas and Politics in Social Science Research, edited by Daniel Beland and Robert Henry Cox, 47-64. Oxford University Press.

Scott, Dayna Nadine, and Andree Boisselle. 2019. "If There Can Only Be 'One Law', It Must Be Treaty Law. Learning from Kanawayandan D'aaki,” Articles \& Book Chapters, . https://digitalcommons.osgoode.yorku.ca/scholarly_works/2745.

Starblanket, Gina. 2019. "Constitutionalizing (In)Justice: Treaty Interpretation and the Containment of Indigenous Governance.” Constitutional Forum 28 (2): 13-24.

Whetung, Emily. 2020. Chief, Curve Lake First Nation, in conversation with the author. 


\section{Bibliography}

Abele, Frances, Katherine A. Graham, and Allan Maslove. 1999. "Negotiating Canada: Changes in Aboriginal Policy over the Last Thirty Years." In Shape Shifting: Canadian Governance Toward the 21st Century, edited by Leslie Pal, 1999-2000:251-92. Oxford University Press.

Abele, Frances, and Michael J. Prince. 2006. "Four Pathways to Aboriginal Self-Government in Canada." American Review of Canadian Studies 36 (4): 568-95.

“Aboriginal Consultation Guide for Preparing a Renewable Energy Approval (REA).” 2016. Ontario Ministry of the Environment, Conservation and Parks. https://www.ontario.ca/page/aboriginal-consultation-guidepreparing-renewable-energy-approval-rea.

"Aboriginal Consultation Policy." 2007. Ontario Energy Board. https://www.oeb.ca/documents/cases/acp_paper_20070618.pdf.

“Aboriginal Peoples Highlight Tables, 2016 Census.” 2020. Statistics Canada. https://www12.statcan.gc.ca/censusrecensement/2016/dp-pd/hlt-fst/abo-aut/Table.cfm?Lang=Eng\&S=99\&O=A\&RPP=25.

Absolon, Kathy, and Cam Willett. 2004. "Aboriginal Research: Berry Picking and Hunting in the 21st Century." First Peoples Child and Family Review 1 (1): 5-17.

Adler, Jonathan H. 2005. "Judicial Federalism and the Future of Environmental Regulation." Iowa Law Review 90: $377-474$.

Administrator, Windigo First Nations Council, in conversation with the author. 2020.

Alcantara, Christopher, and Zachary Spicer. 2015. "Learning from the Kelowna Accord." Policy Options, August, 95-97.

Anishinabek Nation. 2008. “Anishinabek/Ontario Resource Management Council 2007-2008 Annual Report.” http://www.anishinabek.ca/wp-content/uploads/2016/07/Report-2008.pdf.

Anishinabek/Ontario Resource Management Council. 2003a. "Reaching Effective Consultation." Union of Ontario Indians. http://caid.ca/AnishinaabekConPol2003.pdf.

Ariss, Rachel, Clara MacCallum Fraser, and Diba Nazneen Somani. 2017. "Crown Policies on the Duty to Consult and Accommodate: Towards Reconciliation?" McGill Journal of Sustainable Development Law 14 (1): 355.

Asch, Michael. 1984. Home and Native Land: Aboriginal Rights and the Canadian Constitution. Methuen Publications.

- 2014. On Being Here to Stay: Treaties and Aboriginal Rights in Canada. University of Toronto Press.

Assembly of First Nations. 2018a. "Canada's Proposed Recognition and Implementation of Indigenous Rights Framework: Issues Summary.” Assembly of First Nations.

—. 2018b. "National Policy Forum on Affirming Rights, Title, and Jurisdiction." NationTalk, September 25, 2018. http://nationtalk.ca/story/afn-bulletin-national-policy-forum-on-affirming-rights-title-andjurisdiction.

“Assembly of First Nations - Canada Memorandum of Understanding on Joint Priorities." 2017. Assembly of First Nations. https://www.afn.ca/uploads/files/canada-afn-mou-final-eng.pdf.

Association of Municipalities of Ontario. 2019. "Municipal Governments and the Crown's 'Duty to Consult." https://www.amo.on.ca/AMO-PDFs/Reports/2019/AMO-Discussion-Paper-Municipal-Governments-andthe.aspx.

Bankes, Nigel. 2005. "Mikisew Cree and the Lands Taken Up Clause of the Numbered Treaties." Resources, no. 92/93 (Fall /Winter 2006). http://prism.ucalgary.ca/bitstream/1880/47047/1/Resources92-93.pdf.

2010. "Little Salmon and the Juridical Nature of the Duty to Consult and Accommodate." The University of Calgary Faculty of Law Blog on Developments in Alberta Law (blog). 2010. ablawg.ca/wpcontent/uploads/2010/12/blog_nb_salmon_dec2010.pdf.

. 2015. "The Implications of the Tsilhqot'in (William) and Grassy Narrows (Keewatin) Decisions of the Supreme Court of Canada for the Natural Resources Industries.” Journal of Energy \& Natural Resources Law 33 (3): 188-217.

Beck, J.M., ed. 1971. The Shaping of Canadian Federalism: Central Authority or Provincial Right? Issues in Canadian History. Toronto: Copp Clark Publishing.

Beckman v. Little Salmon/Carmacks First Nation. 2010. Supreme Court of Canada.

Bellefeuille, Fred. 2020. Legal Director, Anishinabek Nation, in conversation with the author.

Benedict, Abram. 2020. Grand Chief, Mohawk Council of Akwesasne, in conversation with the author. 
Berger, Benjamin L. 2015. “Judicial Review.” In Introduction to Legal Studies, edited by Stephen Tasson, Jane Dickson, Vincent Kazmierski, Betina Kuzmarov, and Sebastien Malette, 5th ed., 52-56. Canadian Legal Studies. Captus Press.

Bigelow, Donna. 2018. Team Leader, Policy and Relationships Office, Ontario Ministry of Transportation, in conversation with the author.

Binnie, Ian. 2013. "Judging the Judges: 'May They Boldly Go Where Ivan Rand Went Before." Canadian Journal of Law and Jurisprudence 26 (1): 5-21.

Blackburn, Carole. 2005. "Searching for Guarantees in the Midst of Uncertainty: Negotiating Aboriginal Rights and Title in British Columbia." American Anthropologist 107 (4): 586-96.

2007. "Producing Legitimacy: Reconciliation and the Negotiation of Aboriginal Rights in Canada." Journal of the Royal Anthropological Institute 13 (3): 621-38.

Borrows, John. 1996. "With or Without You: First Nations Law (in Canada)." McGill Law Journal 41: 629-67. . 1997a. "Frozen Rights in Canada: Constitutional Interpretation and the Trickster." American Indian Law Review 22 (1): 37-64.

. 1997b. "Wampum at Niagara: The Royal Proclamation, Canadian Legal History, and Self-Government." In Aboriginal and Treaty Rights in Canada, edited by Michael Asch, 170. UBC Press. http://www.chiefs-ofontario.org/sites/default/files/files/Borrows-WampumAtNiagara\%20(2).pdf.

— 1999. "Sovereignty's Alchemy: An Analysis of Delgamuukw v. British Columbia." Osgoode Hall Law Journal 37 (3): 537-96.

2010. Canada's Indigenous Constitution. University of Toronto Press.

. 2012. “(Ab)Originalism and Canada's Constitution.” Supreme Court Law Review 58: 351-98.

. 2017. "Challenging Historical Frameworks: Aboriginal Rights, The Trickster, and Originalism." The Canadian Historical Review 98 (1): 114-35.

Borrows, John, and Leonard I. Rotman. 1997. "The Sui Generis Nature of Aboriginal Rights: Does It Make a Difference?" Alberta Law Review 36 (1): 9-45.

Brennan, William J. 1977. "State Constitutions and the Protection of Individual Rights." Harvard Law Review 90 (3): 489-504.

Brickey, Stephen, and Elizabeth Comack. 2015. "The Role of Law in Social Transformation: Is a Jurisprudence of Insurgency Possible?" In Introduction to Legal Studies, edited by Stephen Tasson, Jane Dickson, Vincent Kazmierski, Betina Kuzmarov, and Sebastien Malette, 5th ed., 556-64. Canadian Legal Studies. Captus Press.

British North America Act. 1867. http://www.justice.gc.ca/eng/rp-pr/csj-sjc/constitution/lawreg-loireg/p1t13.html.

Burrows, Rick. 2015. "Final Ipperwash Settlement Agreement Ratified." Blackburn News, September 19, 2015. https://blackburnnews.com/sarnia/sarnia-news/2015/09/19/final-settlement-agreement-ratified-by-kettleand-stony-point-first-nation/.

Calder et al. v. Attorney-General of British Columbia. 1973 [1973] SCR 313. Supreme Court of Canada.

Campbell, Robert, and Leslie Pal. 1994. "The Rise and Fall of the Charlottetown Accord." In The Real Worlds of Canadian Politics: Cases in Process and Policy, 3rd ed., 142-210. Broadview Press.

Canada, Government of Canada; Indigenous and Northern Affairs. 1982a. Constitution Act, 1982. https://lawslois.justice.gc.ca/eng/Const/page-16.html. 1982b. Constitution Act, 1982. https://laws-lois.justice.gc.ca/eng/Const/page-16.html.

Canada NewsWire. 2008. "NAN Suspends Northern Table until KI Leadership Released," April 3, 2008. http://kilands.org/2008/04/03/nan-suspends-northern-table-until-ki-leadership-released/.

"Canada, Ontario, and Chippewas of Kettle \& Stony Point First Nation Announce Addition of Lands to Their Reserve.” 2020. Ontario Ministry of Indigenous Affairs. https://news.ontario.ca/en/release/58291/canadaontario-and-chippewas-of-kettle-stony-point-first-nation-announce-addition-of-lands-to-their.

CBC News. 2014. "Grassy Narrows Loses Supreme Court Logging Rights Decision,” July 11, 2014. https://www.cbc.ca/news/politics/grassy-narrows-loses-supreme-court-logging-rights-decision-1.2703123.

—. 2019. "Ford's Senior Officials Hoped to Keep Mandate Letters Away from Public View 'as Long as Possible,"” August 22, 2019. https://www.cbc.ca/news/canada/toronto/ford-s-senior-officials-hoped-tokeep-mandate-letters-away-from-public-view-as-long-as-possible-1.5255593.

"Changes on the Horizon: 2017 Long-Term Energy Plan Discussion Guide." 2017. Ontario Ministry of Energy. https://www.ontario.ca/document/2017-long-term-energy-plan-discussion-guide/changes-horizon\#section6. 
Coates, Kenneth. 2020. "How Far We've Come: Indigenous Engagement with the Canadian Energy Economy." Macdonald-Laurier Institute. https://macdonaldlaurier.ca/files/pdf/20201727_Energy\%20Indigenous_Coates_PAPER_FWeb.pdf.

Coates, Kenneth, and Dwight Newman. 2014. "The End Is Not Nigh: Reason over Alarmism in Analysing the Tsilhqot'in Decision." Macdonald-Laurier Institute.

Cody, Howard. 1977. "The Evolution of Federal-Provincial Relations in Canada: Some Reflections." American Review of Canadian Studies 7 (1): 55-83.

Collins, Ronald K.L. 1989. “The Once ‘New Judicial Federalism’ \& Its Critics.” Washington Law Review 64 (5): 518.

“Consultation in Ontario's Environmental Assessment Process." 2014. Ontario Ministry of the Environment, Conservation and Parks. https://www.ontario.ca/page/consultation-ontarios-environmental-assessmentprocess.

Cornell, Stephen, and Joseph P. Kalt. 2010. "American Indian Self-Determination: The Political Economy of a Successful Policy.” John F. Kennedy School of Government, Harvard University. https://poseidon01.ssrn.com/delivery.php?ID=4160711101041210791200710830150800910400340860390 61011092092125127009113065090075110053110119106112108049067000109112123084007033051039 01806011701501908409307606409503805311112007706909111210512007101807400112312209108411 $1120103029099095066069124003 \&$ EXT $=$ pdf.

“Corporate Indigenous Policy.” 2020. Independent Electricity System Operator. https://www.ieso.ca/en/GetInvolved/Indigenous-Relations/Corporate-Indigenous-Policy.

Coulthard, Glen S. 2007. "Subjects of Empire: Indigenous Peoples and the 'Politics of Recognition' in Canada." Contemporary Political Theory 6 (4): 437-60. http://dx.doi.org.proxy.library.carleton.ca/10.1057/palgrave.cpt.9300307.

_. 2014. Red Skin, White Masks. Minneapolis: University of Minnesota Press.

Craft, Aimee. 2011. "Treaty Interpretation: A Tale of Two Stories." www.cba.org/cba/cle/PDF/ABOR11_Craft_Paper.pdf. . 2014. "Living Treaties, Breathing Research." Canadian Journal of Women and the Law 26: 1-22.

Davis, Lynne, and Chris Hiller. n.d. "Engaging Citizens in Indigenous/Non-Indigenous Relations." In Sharing the Land, Sharing a Future, edited by Katherine A. Graham and David Newhouse. University of Manitoba Press.

Dawson, Robert MacGregor, ed. 1933. Constitutional Issues in Canada, 1900-1931. Oxford University Press.

Delgamuukw v. British Columbia. 19973 SCR 1010. Supreme Court of Canada.

Department of Justice Canada. 2018. "The Attorney General of Canada's Directive on Civil Litigation Involving Indigenous Peoples.” https://www.justice.gc.ca/eng/csj-sjc/ijr-dja/dclip-dlcpa/litigation-litiges.pdf.

"Deputy Minister Committees: Committee Mandates and Membership.” 2020. Privy Council Office. https://www.canada.ca/en/privy-council/programs/appointments/senior-public-service/deputy-ministercommittees.html.

Director, Ontario Ministry of Indigenous Affairs, in conversation with the author. 2018a.

- 2018b.

Dodds, Klaus. 2012. "Graduated and Paternal Sovereignty: Stephen Harper, Operation Nanook 10, and the Canadian Arctic." Environment and Planning D: Society and Space 30: 989-1010.

Dorries, Heather. 2012. "Rejecting the 'False Choice': Foregrounding Indigenous Sovereignty in Planning Theory and Practice." PhD, University of Toronto. https://tspace.library.utoronto.ca/bitstream/1807/65468/1/Dorries_Heather_J_201206_PhD_thesis.pdf.

"Draft Guidelines for Ministries on Consultation with Aboriginal Peoples Related to Aboriginal Rights and Treaty Rights.” 2015. Ontario Ministry of Indigenous Affairs. https://www.ontario.ca/page/draft-guidelinesministries-consultation-aboriginal-peoples-related-aboriginal-rights-and-treaty.

Dubinski, Kate. 2020. "25 Years after His Death, Dudley George's Fight for the Land Continues." CBC News, September 6, 2020. https://www.cbc.ca/news/canada/london/dudley-george-kettle-stony-point-25anniversary-1.5708055.

"Duty to Consult with Aboriginal Peoples in Ontario: Information on Ontario's Duty to Consult Aboriginal Peoples." 2013. Ontario Ministry of Indigenous Affairs. https://www.ontario.ca/page/duty-consultaboriginal-peoples-ontario.

“Fact Sheet 10: 2016 Census Highlights." 2017. Ontario Ministry of Finance. https://www.fin.gov.on.ca/en/economy/demographics/census/cenhi16-10.pdf. 
Finch, Lance S.G. 2012. "The Duty to Learn: Taking Account of Indigenous Legal Orders in Practice.” In . https://www.cerp.gouv.qc.ca/fileadmin/Fichiers_clients/Documents_deposes_a_la_Commission/P-253.pdf.

"First Nation and Metis Consultation Policy Framework." 2010. Government of Saskatchewan. https://www.saskatchewan.ca/residents/first-nations-citizens/duty-to-consult-first-nations-and-metiscommunities.

Flanagan, Tom. 2000. First Nations, Second Thoughts. McGill-Queen's University Press.

(former) Acting Manager, Ontario Ministry of Energy, in conversation with the author. 2018.

(former) Legal counsel, Ontario Ministry of Indigenous Relations and Reconciliation, in conversation with the author. 2018.

(former) Policy Advisor, Ontario Ministry of Natural Resources and Forestry, in conversation with the author. 2020.

Fraser, Nancy. 1992. "Rethinking the Public Sphere: A Contribution to the Critique of Actually Existing Democracy." In Habermas and the Public Sphere, edited by C. Calhoun. Cambridge, Massachusetts: MIT Press.

Friedman, Lawrence. 2000. "The Constitutional Value of Dialogue and the New Judicial Federalism." Hastings Constitutional Law Quarterly 28: 93-143.

"Funding for Indigenous Economic Development." 2014. Ontario Ministry of Indigenous Affairs. https://www.ontario.ca/page/funding-indigenous-economic-development.

Gibson, Dale. 1966. "Constitutional Amendment and the Implied Bill of Rights." McGill Law Journal 12 (4): 497501.

Government of Canada. 1997. "Gathering Strenth: Canada's Aboriginal Action Plan.” Ministry of Indian Affairs and Northern Development. http://www.ahf.ca/downloads/gathering-strength.pdf.

Government of Ontario. 1998. Electricity Act, 1998. S.O. 1998, c.15. https://www.ontario.ca/laws/statute/98e15. 2007. "Report of the Ipperwash Inquiry, Volume 4." https://www.attorneygeneral.jus.gov.on.ca/inquiries/ipperwash/report/vol 4/pdf/E Vol 4 Full.pdf. . 2009a. An Act to Amend the Mining Act. SO 2009, c. 21 - Bill 173. https://www.ontario.ca/laws/statute/S09021. 2009b. Green Energy Act. S.O. 2009, c.12. https://www.ontario.ca/laws/statute/09g12. . 2010. Far North Act. S.O. 2010, c.18. https://www.ontario.ca/laws/statute/10f18. 2016a. "Mandate Letter Progress: Aboriginal Affairs." https://www.ontario.ca/page/mandate-letterprogress-aboriginal-affairs.

— 2016b. "Published Plans and Annual Reports 2016-2017: Ministry of Aboriginal Affairs." https://www.ontario.ca/page/published-plan-and-annual-report-ministry-of-aboriginal-affairs.

. 2017a. Child, Youth and Family Services Act. S.O. 2017, c.14. https://www.ontario.ca/laws/statute/17c14.

. 2017b. "Published Plans and Annual Reports 2017-2018: Ministry of Indigenous Relations and Reconciliation." https://www.ontario.ca/page/published-plans-and-annual-reports-2017-2018-ministryindigenous-relations-and-reconciliation.

—. 2019. "Published Plans and Annual Reports 2019-2020: Ministry of Indigenous Affairs." https://www.ontario.ca/page/published-plans-and-annual-reports-2019-2020-ministry-indigenous-affairs. 2020. Security from Trespass and Protecting Food Safety Act. S.O. 2020, c.9. https://www.ontario.ca/laws/statute/20s09.

_. n.d. "Map of Ontario Treaties and Reserves." Accessed February 28, 2020. https://www.ontario.ca/page/map-ontario-treaties-and-reserves.

Grammond, Sebastien. 2016. "Compact Is Back: The Supreme Court Od Canada's Revival of the Compact Theory of Confederation." Osgoode Hall Law Journal 53: 799-823.

Grassy Narrows First Nation v. Ontario (Natural Resources). 2014. Supreme Court of Canada.

Gray, Bryn. 2016. "Building Relationships and Advancing Reconciliation through Meaningful Consultation." Indigenous and Northern Affairs Canada. https://www.rcaanccirnac.gc.ca/eng/1498765671013/1609421492929.

Gray, Tim. 2020. "You May Have Never Heard of a Minister's Zoning Order and That Used to Be Ok - but Not Anymore." Environmental Defence. https://environmentaldefence.ca/2020/08/28/may-never-heardministers-zoning-order-used-ok-not-anymore/.

Greenwood, F. Murray. 1974. "Lord Watson, Institutional Self-Interest, and the Decentralization of Canadian Federalism in the 1890s." University of British Columbia Law Review 9 (2): 244-69, 274-79.

Guerin v. The Queen. 1984 [1984] 2 SCR 335. Supreme Court of Canada.

Habermas, Jurgen. 1998. Between Facts and Norms. MIT Press. 
2005. “Three Normative Models of Democracy." In Political Philosophy: The Essential Texts, edited by Steven M. Cahn, 527-41. Oxford University Press.

Haida Nation v. British Columbia (Minister of Forests). 2004 [2004] 3 SCR 511. Supreme Court of Canada.

Hajer, Maarten, and Henrik Wagenaar. 2003. "Introduction." In Deliberative Policy Analysis: Understanding Governance in the Network Society, 1-30. Cambridge University Press.

Hall, Peter A., and Kathleen Thelen. 2007. "Institutional Change in Varieties of Capitalism."

Henderson, James (Sakej) Youngblood. 1994. "Empowering Treaty Federalism.” Saskatchewan Law Review 58: 241-329.

Hill Sloan Associates, Inc. 2008. "First Nation Consultation Framework." National Centre for First Nations Governance. http://www.fngovernance.org/resources_docs/First_Nation_ConsultationFramework.pdf.

Hoehn, Felix. 2012. Reconciling Sovereignties: Aboriginal Nations and Canada. Saskatoon: Native Law Centre, University of Saskatchewan.

Hogg, Peter W., and Allison A. Bushell. 1997. "The Charter Dialogue between Courts and Legislatures (Or Perhaps the Charter of Right Isn't Such a Bad Thing After All)." Osgoode Hall Law Journal 35 (1): 75-124.

Hogg, Peter W., and Mary Ellen Turpel. 1995. "Implementing Aboriginal Self-Government: Constitutional and Jurisdictional Issues." The Canadian Bar Review 74 (2): 187-224.

"Honouring Our Ancenstors by Trailblazing a Path to the Future: Interim Report of the Joint Advisory Committee on Fiscal Relations - for Engagement Purposes.” 2019. Indigenous Services Canada. https://www.sacisc.gc.ca/eng/1561371591558/1561371616958.

"Honouring the Truth, Reconciling for the Future: Summary of the Final Report of the Truth and Reconciliation Commission of Canada." 2015. Truth and Reconciliation Commission of Canada.

Hunter, David, Nalin Sahni, and George McKibbon. 2012. "A New Paradigm for Aboriginal Consultation in Ontario.” Ontario Bar Association. http://www.oba.org/en/pdf/sec_news_abo_dec12_par_hun.pdf.

Indigenous and Northern Affairs Canada. 2016. "Algonquins of Ontario Land Claim Negotiations." https://www.aadnc-aandc.gc.ca/eng/1355436558998/1355436749970.

"Indigenous Conservation Programming: A New Approach - Report on Energy Conservation for First Nations and Métis in Ontario.” 2018. Independent Electricity System Operator. https://www.ieso.ca/en/GetInvolved/Indigenous-Relations/Overview.

Institute of Public Administration of Canada. 2017. "Public Service Action for Reconciliation: Plan, Educate, Engage.” National Year of Dialogue for Reconciliation \& Renewed Relationships. https://s3.ca-central1.amazonaws.com/ipacreports/NYD+Report+-+Final+-+English.pdf.

"Inuit Nunangat Declaration on Inuit-Crown Partnership." 2017. Inuit Tapiriit Kanatami. https://www.itk.ca/wpcontent/uploads/2017/02/English-Inuit-Nunangat-Declaration.pdf.

Jai, Julie. 2009. "The Interpretation of Modern Treaties and the Honour of the Crown: Why Modern Treaties Deserve Judicial Deference." National Journal of Constitutional Law 26 (1): 25-65.

Joffe, Paul. 2015. “'Veto' and 'Consent' - Significant Differences.” Assembly of First Nations. afn.ca/uploads/files/2015_usb_documents/veto-and-consent-significant-differences-joffe-final-july-3115.pdf.

Johnson, Rhiannon. 2019. “Ontario Budget's Cuts to Indigenous Affairs a Setback for Reconciliation, Says Carolyn Bennett.” CBC News, April 12, 2019. https://www.cbc.ca/news/indigenous/ontario-budget-indigenousaffairs-cut-1.5096723.

Kapyrka, Julie. 2018. "The Space Between: The Benefits of a Pre-Engagement Consultation Model." Public Sector Digest, October 2018.

2021. Consultation Liaison, Curve Lake First Nation, in conversation with the author.

King, Hayden. 2018. "Canada's Indigenous Rights Framework: A (Bad) Proposal Emerges.” Policy Brief, September 19, 2018.

. 2020a. "The Rise Of The Anishinabek Nation: Self-Government For The Status Quo?" Yellowhead Institute, Ryerson University. https://yellowheadinstitute.org/2020/01/15/the-rise-of-the-anishinabeknation/.

— 2020b. "The Rise Of The Anishinabek Nation, Part II: The Fiscal Agreement." Yellowhead Institute, Ryerson University. https://yellowheadinstitute.org/2020/02/06/the-rise-of-the-anishinabek-nation-part-iifiscal-agreement/.

2020c. "CIRN-ACK! Leaked Government Document Outlines The Indian Department's 'Indigenous Agenda' And 'Accomplishments' For 2019-2020.” Yellowhead Institute, Ryerson University. https://yellowheadinstitute.org/2020/08/11/cirn-ack-leaked-government-document-outlines-the-indiandepartments-indigenous-agenda-and-accomplishments-for-2019-2020/. 
Knopff, Rainer, and F.L. Morton. 2015. “Ardour in the Court.” In Introduction to Legal Studies, edited by Stephen Tasson, Jane Dickson, Vincent Kazmierski, Betina Kuzmarov, and Sebastien Malette, 5th ed., 544-45. Canadian Legal Studies. Captus Press.

Kohoko, Dan. 2020. Councillor, Algonquins of Pikwakanagan First Nation, in conversation with the author.

Ladner, Kiera L. 2005. "Up the Creek: Fishing for a New Constitutional Order." Canadian Journal of Political Science 38 (4): 923-53.

2006. "Indigenous Governance: Questioning the Status and the Possibilities for Reconciliation with Canada's Commitment to Aboriginal and Treaty Rights." National Centre for First Nations Governance.

Land, Lorraine. 2014. "Creating the Perfect Storm for Conflicts Over Aboriginal Rights: Critical New Devlopments in the Law of Aboriginal Consultation." Olthuis Kleer Townshend LLP. http://www.oktlaw.com/wpcontent/uploads/2016/10/lylPerfectStorm.pdf.

Laskaris, Sam. 2020. "First Nation Chiefs Content with Pandemic Communications from Ontario Government." Windspeaker, July 16, 2020. https://windspeaker.com/news/windspeaker-news/first-nation-chiefs-contentpandemic-communications-ontario-government.

Lawrence, Sonia, and Patrick Macklem. 2000. "From Consultation to Reconciliation: Aboriginal Rights and the Crown's Duty to Consult." Canadian Bar Review 79: 252-79.

Livingston, William S. 1956. "The Amendment of the Canadian Constitution." In Federalism and Constitutional Change, 16-109. Oxford University Press.

Llewellyn, Karl. 2015. “This Case System: Precedent.” In Introduction to Legal Studies, edited by Stephen Tasson, Jane Dickson, Vincent Kazmierski, Betina Kuzmarov, and Sebastien Malette, 5th ed., 162-64. Canadian Legal Studies. Captus Press.

Long, J. Anthony, Leroy Little Bear, and Menno Boldt. 1984. "Federal Indian Policy and Indian Self-Government in Canada." In Pathways to Self-Determination: Canadian Indians and the Canadian State, 69-84. Toronto: University of Toronto Press.

Lowndes, Vivien, and Mark Roberts. 2013. “Three Phases of Institutionalism.” In Why Institutions Matter: The New Institutionalism in Political Science, 18-45. Palgrave-Macmillan.

Lysyk, Bonnie. 2020. "Value-for-Money Audit: Indigenous Affairs in Ontario." Office of Auditor General of Ontario. https://www.auditor.on.ca/en/content/annualreports/arreports/en20/20VFM_04indigenous.pdf.

MacDonald, Vincent C. 1951. "The Privy Council and the Canadian Constitution." Canadian Bar Review 29: 102137.

Madden, Jason, and Alexandria Winterburn. 2020. "Implementing the MNO Self Government Agreement." Presented at the Provisional Council of the Metis Nation of Ontario, July 26. http://www.metisnation.org/media/1365497/2020-07-26-pst-presentation-to-pcmno-re-mgrsaimplementation.pdf.

Mallory, J.R. 1941. "The 'Compact' Theory of Confederation.” Dalhousie Review 21 (3): 342-51.

Manager, Ontario Ministry of Health, in conversation with the author. 2018.

Manuel, Arthur, and Ronald Derrickson. 2017. The Reconciliation Manifesto: Recovering the Land, Rebuilding the Economy. Toronto: James Lorimer and Company Ltd.

McCrossan, Michael. 2012. "Judicial Narratives of Crown Sovereignty, Territorial Space, and the Perpetuation of Legal Magic.” Doctor of Political Science, Ottawa, ON: Carleton University.

McCrossan, Michael, and Kiera L. Ladner. 2016. "Eliminating Indigenous Jurisdictions: Federalism, the Supreme Court of Canada, and Territorial Rationalities of Power." Canadian Journal of Political Science / Revue Canadienne de Science Politique 49 (3): 411-31.

McCurry, Pamela. 2017. "Concept Paper 1: Critical Conversation on Reconciliation." 2020. "Section 35 Legal Framework: Implications for Evaluation." Canadian Journal of Program Evaluation 34 (3): 400-412.

McIntosh, Emma. 2020a. "Group Representing 133 First Nations Backs Legal Challenge of Ford's Weakening of Environmental Assessments." National Observer, August 28, 2020. https://www.nationalobserver.com/2020/08/28/news/coalition-133-first-nations-planning-legal-challengefords-bill-197?utm_source $=$ National + Observer\&utm_campaign $=$ d3041972fe-

EMAIL_CAMPAIGN_2020_08_28_12_43\&utm_medium=email\&utm_term=0_cacd0f141f-d3041972fe$254436 \overline{6} 25$.

2020b. "Three First Nations File Suit against Ford Government over Lack of Consultation on Forestry." National Observer, September 22, 2020. https://www.nationalobserver.com/2020/09/22/news/three-firstnations-file-suit-against-ford-government-over-lack-consultation. 
. 2020c. “Auditor General Issues Scathing Rebuke of Ford Government's Environmental Policies.” National Observer, November 18, 2020. https://www.nationalobserver.com/2020/11/17/news/auditor-generalrebuke-ford-government-environmental-policies.

McIvor, Bruce. 2015. "First Peoples Law 2014." First Peoples Law Corporation.

McIvor, Bruce, and Kate Gunn. 2016. "Stepping into Canada's Shoes: Tsilhqot'in, Grassy Narrows and the Division of Powers." University of New Brunswick Law Journal 67: 146-66.

McLean, Iain, and Alistair McMillan, eds. 2009. "Power." In The Concise Oxford Dictionary of Politics, 3rd ed., 425-28. Oxford University Press.

McLeod Rogers, Norman. 1931. "The Compact Theory of Confederation.” In Proceedings of the Canadian Political Science Association, 205-30. Canadian Political Science Association.

McNeil, Kent. 1996. "Aboriginal Governments and the Canadian Charter of Rights and Freedoms." Osgoode Hall Law Journal 34 (1): 61-99. 2001. Emerging Justice? Essays on Indigenous Rights in Canada and Australia. Saskatoon: Native Law Centre, University of Saskatchewan.

2005. "Aboriginal Rights, Resource Development, and the Source of the Provincial Duty to Consult in Haida Nation and Taku River." Supreme Court Law Review 29 (1): 447-60.

. 2007. "The Jurisdiction of Inherent Right Aboriginal Governments." National Centre for First Nations Governance.

. 2010. "Reconciliation and Third-Party Interests: Tsilhqot'in Nation v. British Columbia." Indigenous Law Journal 8 (1): 7-26.

2015. "Aboriginal Title and the Provinces after Tsilhqot'in Nation." Supreme Court Law Review 71: 67-89.

. 2016. "Aboriginal Title and Indigenous Governance: Identifying the Holders of Rights and Authority,"

Indian and Aboriginal Law Commons, . http://digitalcommons.osgoode.yorku.ca/all_papers/264.

. 2019. Flawed Precedent: The St. Catherine's Case and Aboriginal Title. UBC Press.

Mikisew Cree First Nation v. Canada (Minister of Canadian Heritage). 2005. Supreme Court of Canada.

Miller, Jim R. 2013. "Aboriginal-Crown Treaty-Making in Canada: A Many-Splendoured Thing." In A History of Treaties and Policies, edited by Jerry P. White, Erik Anderson, Jean Pierre Morin, and Dan Beavon, 7:312. Aboriginal Policy Research. Thompson Educational Publishing.

2018. "Compact, Contract, Covenant: The Evolution of First Nations Treaty-Making." In Reconsidering Conferderation: Canada's Founding Debates, 1864-1999, edited by Daniel Heidt, 19-51. University of Calgary Press.

Milloy, John S. 1999. A National Crime: The Canadian Government and the Residential School System, 1879 to 1986. University of Manitoba Press.

https://books.google.ca/books/about/A_National_Crime.html?id=TSGmglyxgzkC\&printsec=frontcover\&so urce $=\mathrm{kp} \_$read_button\&redir_esc $=\mathrm{y} \# \mathrm{v}=$ onepage $\& \mathrm{q} \& \mathrm{f}=$ false.

Ministry of Indigenous Relations and Reconciliation. 2017. "One-Year Progress Report - The Journey Together: Ontario's Commitment to Reconciliation with Indigenous Peoples."

https://files.ontario.ca/progress_report1_en_web.pdf.

MNRF, Far North Branch. 2015a. "Preparing the Far North Land Use Strategy: An Update and Overview of Path Forward." Presented at the Northern Ontario First Nations Environmental Conference 2015. https://www.nofnec.ca/PDF/2015/Values_Protection_Far_North_Strategy.pdf.

_. 2015b. "Far North Land Use Strategy: A Draft." Ontario Ministry of Natural Resources and Forestry. https://www.ossga.com/multimedia/0/draft_far_north_strategy_2015_09_29.pdf.

“Modernizing Ontario's Environmental Assessment Program.” 2019. Ontario Ministry of the Environment, Conservation and Parks. https://prod-environmental-registry.s3.amazonaws.com/201904/EA\%20Discussion\%20Paper.pdf.

Morellato, Maria. 2008. "The Crown's Constitutional Duty to Consult and Accommodate Aboriginal and Treaty Rights." National Centre for First Nations Governance.

Morton, F.L. 2003. “Can Judicial Supremacy Be Stopped?” Policy Options, October, 25-29.

- 2015. "Precedents, Statutes and Legal Reasoning." In Introduction to Legal Studies, edited by Stephen Tasson, Jane Dickson, Vincent Kazmierski, Betina Kuzmarov, and Sebastien Malette, 5th ed., 157-59. Canadian Legal Studies. Captus Press.

Morton, F.L., and Rainer Knopff. 2000. "Judges, the Court Party and the Charter Revolution." Policy Options, April, 55-60.

Munson, James. 2017. "Duty to Consult Seen by Some as 'Dismal Failure': Report." IPolitics, June 30, 2017. https://ipolitics.ca/2017/06/30/duty-to-consult-seen-by-some-as-dismal-failure-says-report/. 
Nahwegahbow, David C. 2002. "Recognition of Inherent Rights Through Legislative Initiatives." In . Toronto, Canada: Indigenous Bar Association.

Napoleon, Val. 2007. "Thinking About Indigenous Legal Orders." National Centre for First Nations Governance.

Narine, Shari. 2020. "What Happened to the Treaty Commission of Ontario after Ipperwash Inquiry

Recommendation?" Windspeaker, September 3, 2020.

https://windspeaker.com/index.php/news/windspeaker-news/what-happened-treaty-commission-ontarioafter-ipperwash-inquiry.

New Brunswick and Canada: Royal Commission on Dominion-Provincial Relations. 1938. Submission by the Government of the Province of New Brunswick to the Royal Commission on Dominion-Provincial Relations. Fredericton.

Newhouse, David. 2016. "Indigenous Peoples, Canada and the Possibility of Reconciliation." IRPP Insight, no. 11 (November).

Newman, Dwight. 2011. "Contractual and Covenantal Conceptions of Modern Treaty Interpretation." Supreme Court Law Review 54: 475-91.

. 2014a. Revisiting the Duty to Consult Aboriginal Peoples. Saskatoon: Purich Publishing Ltd.

2014b. "The Rule and the Role of Law: The Duty to Consult, Aboriginal Communities, and the Canadian Natural Resource Sector." 4. Aboriginal Canada and the Natural Resource Economy Series. Ottawa: Macdonald-Laurier Institute.

North Bay Nugget. 2020. "More Votes Scheduled on Anishinabek Nation Governance Agreement," March 6, 2020. https://www.nugget.ca/news/local-news/more-votes-scheduled-on-anishinabek-nation-governanceagreement.

Olynyk, John. 2005. "The Haida Nation and Taku River Tlingit Decisions: Clarifying Roles and Responsibilities for Aboriginal Consultation and Accommodation." Lawson Lundell LLP.

"Ontario and Anishinabek Nation Renew Commitments on Natural Resource Management." 2016. Ontario Ministry of Natural Resources and Forestry. https://news.ontario.ca/en/release/36219/ontario-and-anishinabeknation-renew-commitments-on-natural-resource-management.

"Ontario Commemorates 25th Anniversary of Ipperwash Park Tragedy." 2020. Ontario Ministry of Indigenous Affairs. https://news.ontario.ca/en/statement/58272/ontario-commemorates-25th-anniversary-of-ipperwashpark-tragedy.

Ontario Ministry of Northern Development and Mines. 2012. "MNDM Policy: Consultation and Arrangements with Aboriginal Communities at Early Exploration." Government of Ontario. https://web.archive.org/web/20190711204417/https://www.mndm.gov.on.ca/sites/default/files/aboriginal_e xploration_consultation_policy.pdf.

“Ontario’s Long-Term Energy Plan 2017: Delivering Fairness and Choice.” 2017. Ontario Ministry of Energy. https://files.ontario.ca/books/ltep2017_0.pdf.

“Ontario's New Approach to Aboriginal Affairs." 2005. Ontario Native Affairs Secretariat. http://docs.files.ontario.ca/documents/222/6-maa-new-approach-to-aboriginal-affairs.pdf.

Papillon, Martin. 2011. "Adapting Federalism: Indigenous Multilevel Governance in Canada and the United States." Publius: The Journal of Federalism 42 (2): 289-312.

"Partners In Confederation: Aboriginal Peoples, Self-Government, and the Constitution." 1993. Royal Commission on Aboriginal Peoples. http://data2.archives.ca/rcap/pdf/rcap-441.pdf.

Pasternak, Shiri. 2017. Grounded Authority: The Algonquins of Barriere Lake against the State. Minneapolis: University of Minnesota Press.

Peach, Ian. 2016. "Who Speaks for Whom? Implementing the Crown's Duty to Consult in the Case of Divided Aboriginal Political Structures." Canadian Public Administration 59 (1): 95-112.

Peters, B. Guy, Jon Pierre, and Desmond King. 2005. "The Politics of Path Dependency: Political Conflict in Historical Institutionalism." The Journal of Politics 67 (4): 1275-1300.

Pigeon, Louis-Phillipe. 1951. "The Meaning of Provincial Autonomy.” Canadian Bar Review 29 (2): 35-46.

"Political Accord Between First Nations and the Government of Ontario." 2015. Ontario Ministry of Indigenous Affairs. https://news.ontario.ca/en/backgrounder/33998/political-accord-between-first-nations-and-thegovernment-of-ontario.

Porter, Tom. 1984. "Traditions of the Constitution of the Six Nations." In Pathways to Self-Determination: Canadian Indians and the Canadian State, edited by Leroy Little Bear, Menno Boldt, and J. Anthony Long, 14-21. Toronto: University of Toronto Press.

Potes, Veronica. 2006. "The Duty to Accommodate Aboriginal Peoples Rights: Substantive Consultation?” Journal of Environmental Law and Practice 17 (1): 27-45. 
"Principles Respecting the Government of Canada's Relationship with Indigenous Peoples." 2018. Department of Justice Canada. https://www.justice.gc.ca/eng/csj-sjc/principles.pdf.

Promislow, Janna. 2013. "Irreconcilable? The Duty to Consult and Administrative Decision Makers." Constitutional Forum 22 (1): 63-78.

Reddekopp, Neil. 2013. "Theory and Practice in the Government of Alberta's Consultation Policy." Constitutional Forum 22 (1): 47-62.

Reid, Randy. 2018. (former) Director, Negotiations Branch, Ontario Ministry of Indigenous Relations and Reconciliation, in conversation with the author.

Restoule v. Canada (Attorney General). 2018. Ontario Superior Court of Justice. 2020. Ontario Superior Court of Justice.

Review of Laws and Policies Secretariat. 2017. "Co-Chair Meeting Scenario Note with Speaking Points, Deputy Ministers' Task Force on Reconciliation.” Briefing Document. Ottawa, ON: Department of Justice Canada.

Rice, Waubgeshig. 2018. "Ontario First Nations Acquire 14 Million Shares of Hydro One." CBC News, January 4, 2018. https://www.cbc.ca/news/indigenous/ontario-first-nations-hydro-one-shares-1.4473126.

Riddell, Troy Q. 2004. "The Impact of Legal Mobilization and Judicial Decisions: The Case of Official MinorityLanguage Education Policy in Canada for Francophones Outside Quebec." Law \& Society Review 38 (3): 583-609.

Ritchie, Kaitlin. 2013. "Issues Associated with the Implementation of the Duty to Consult and Accommodate Aboriginal Peoples: Threatening the Goals of Reconciliation and Meaningful Consultation." University of British Columbia Law Review 46 (2): 397-438.

Roach, Kent. 2001. The Supreme Court on Trial: Judicial Activism or Democratic Dialogue. Irwin Law.

Romney, Paul. 1999. "Provincial Equality, Special Status, and the Compact Theory of Canadian Confederation." Canadian Journal of Political Science 32 (1): 21-39.

Rotman, Leonard I. 1997. "Taking Aim at the Canons of Treaty Interpretation in Canadian Aboriginal Rights Jurisprudence." University of New Brunswick Law Journal 46: 11.

Royal Commission on Aboriginal Peoples. 1996a. Looking Forward, Looking Back. Vol. 1. 6 vols. Government of Canada.

1996b. Restructuring the Relationship. Vol. 2. 6 vols. Report of the Royal Commission on Aboriginal Peoples. Government of Canada.

Royal Proclamation. 1763. https://www.aadnc-aandc.gc.ca/eng/1370355181092/1370355203645.

Sabin, Jerald. 2017. "A Federation within a Federation? Devolution and Indigenous Government in the Northwest Territories." 66. IRPP Study. Institute for Research on Public Policy.

Sanders, Douglas. 1983. "The Indian Lobby." In And No One Cheered: Federalism, Democracy and the Constitution Act, edited by Keith Banting and Richard Simeon, 301-32. Methuen Publications. 1983b. "The Rights of the Aboriginal Peoples of Canada." Canadian Bar Review 61: 314-38.

Saul, John Ralston. 2009. "The Roots of Canadian Law in Canada.” McGill Law Journal 54: 671-94.

- 2012. "A Different Model of the Nation-State: Canada in the World and the Aboriginal Influence." Saskatchewan Law Review 75: 3-12.

Schmidt, Vivien. 2008. "Discursive Institutionalism: The Explanatory Power of Ideas and Discourse." Annual Review of Political Science 11: 303-26.

- 2010. "Taking Ideas and Discourse Seriously: Explaining Change through Discursive Institutionalism as the Fourth 'New Institutionalism.” European Political Science Review 2 (1): 1-25.

- 2011. "Reconciling Ideas and Institutions through Discursive Institutionalism." In Ideas and Politics in Social Science Research, edited by Daniel Beland and Robert Henry Cox, 47-64. Oxford University Press.

Schwartz, Bryan. 1986. First Principles, Second Thoughts: Aboriginal Peoples, Constitutional Reform and Canadian Statecraft. Montreal: Institute for Research on Public Policy.

Schwartz, Bryan, and Darla L. Rettie. 2006. "The Long and Winding Road: Case Comment on Mikisew Cree First Nations v. Canada (Minister of Canadian Heritage)." Supreme Court Law Review 34: 465-75.

Scott, Dayna Nadine. 2019. "Doug Ford's Repeal of the Far North Act Won't Gain the Respect of Indigenous Communities." Globe and Mail, March 25, 2019. https://www.theglobeandmail.com/opinion/article-dougfords-repeal-of-the-far-north-act-wont-gain-the-respect-of/.

Scott, Dayna Nadine, and Andree Boisselle. 2019. "If There Can Only Be 'One Law', It Must Be Treaty Law. Learning from Kanawayandan D'aaki," Articles \& Book Chapters, . https://digitalcommons.osgoode.yorku.ca/scholarly_works/2745. 
Scott, Dayna Nadine, and John Cutfeet. 2019. “After the Far North Act: Indigenous Jurisdiction In Ontario’s Far North.” Yellowhead Institute, Ryerson University. https://yellowheadinstitute.org/2019/07/09/after-the-farnorth-act/.

Seymour, Janine. 2014. “Casenote: Grassy Narrows First Nation v. Ontario (Natural Resources).” Indigenous Law Bulletin 8 (18): 30-33.

Shepherd, Robert. 2018. "Indigenous Peoples and the Reconciliation Agenda: Funding, Accountability and Risk." In The Handbook of Canadian Public Administration, edited by Christopher Dunn, 3rd ed., 246-68. Toronto: Oxford University Press.

Simpson, Audra. 2017. "The Ruse of Consent and the Anatomy of 'Refusal': Cases from Indigenous North America and Australia." Postcolonial Studies 20 (1): 18-33.

Slattery, Brian. 1984. "The Hidden Constitution: Aboriginal Rights in Canada." American Journal of Comparative Law 32 (2): 361-91.

1987. "Understanding Aboriginal Rights." Canadian Bar Review 66 (4): 727-83.

1992. "First Nations and the Constitution: A Question of Trust." Canadian Bar Review 71 (2): $261-93$.

1996. "The Organic Constitution: Aboriginal Peoples and the Evolution of Canada." Osgoode Hall Law Journal 34 (1): 101-12.

2000. "Making Sense of Aboriginal and Treaty Rights." Canadian Bar Review 79 (2): 196-224.

2005. "Aboriginal Rights and the Honour of the Crown." Supreme Court Law Review 29 (2d): 433-45.

2006. "The Metamorphosis of Aboriginal Title." Canadian Bar Review 85 (2): 255-86.

2014. "The Aboriginal Constitution." Supreme Court Law Review 67: 319-36.

Slowey, Gabrielle A. 2007. "Federalism and First Nations: In Search of Space." In Constructing Tomorrow's Federalism: New Perspectives on Canadian Governance, edited by Ian Peach, 157-70. University of Manitoba Press.

Snow, Dave, and Mark S. Harding. 2015. "From Normative Debates to Comparative Methodology: The Three Waves of Post-Charter Supreme Court Scholarship in Canada." American Review of Canadian Studies 45 (4): 451-66.

Sossin, Lorne. 2010. "The Duty to Consult and Accommodate: Procedural Justice as Aboriginal Rights." Canadian Journal of Administrative Law \& Practice 23: 93-113.

Stanley, George F.G. 1956. "Act or Pact? Another Look at Confederation.” In Annual Report of the Canadian Historical Association, 11-25.

Stanton, Kim. 2017. "Reconciling Reconciliation: Differing Conceptions of the Supreme Court of Canada and the Canadian Truth and Reconciliation Commission." Journal of Law and Social Policy 26 (2): 21-42.

Starblanket, Gina. 2019. "Constitutionalizing (In)Justice: Treaty Interpretation and the Containment of Indigenous Governance." Constitutional Forum 28 (2): 13-24.

Starblanket, Gina, and Dallas Hunt. 2020. "COVID-19, The Numbered Treaties \& The Politics of Life." Yellowhead Institute, Ryerson University. https://yellowheadinstitute.org/wp-content/uploads/2020/06/yi-specialreport-covid19-and-treaties.pdf.

Statistics Canada. 2016. "Aboriginal Peoples in Canada: First Nations People, Metis and Inuit." http://www12.statcan.gc.ca/nhs-enm/2011/as-sa/99-011-x/99-011-x2011001-eng.cfm\#a3.

Sterling, Lori, and Peter Landmann. 2009. "The Duty to Consult Aboriginal Peoples - Government Approaches to Unresolved Issues." Canadian Bar Association. www.cba.org/cba/cle/PDF/Constit09_Sterling_paper.pdf.

Stonechild, Blair. 2018. "Office of the Treaty Commissioner.” In Indigenous Saskatchewan Encyclopedia. University of Regina Press. https://teaching.usask.ca/indigenoussk/import/office_of_the_treaty_commissioner.php.

Streeck, Wolfgang, and Kathleen Thelen. 2005. "Institutional Change- in Advanced Political Economies." In Beyond Continuity: Institutional Change in Advanced Economies, edited by Wolfgang Streeck and Kathleen Thelen, 1-35. Oxford University Press.

"Sustainable Forest Management Policy." 2016. Algonquin Forest Authority. http://algonquinforestry.on.ca/wpcontent/uploads/SFM-Policy-Final_Nov-2016.pdf.

Taku River Tlingit First Nation v. British Columbia (Project Assessment Director). 2004 [2004] 3 SCR 550. Supreme Court of Canada.

Tarr, G. Alan. 1999. "The New Judicial Federalism in Perspective." Notre Dame Law Review 72 (4): $1097-1118$.

"The Dene Declaration." 1976. Canadian Association in Support of the Native Peoples Bulletin 17 (1): 3.

“The Journey Together: Ontario’s Commitment to Reconciliation with Indigenous Peoples.” 2016. Ontario Ministry of Indigenous Affairs. https://www.ontario.ca/page/journey-together-ontarios-commitment-reconciliationindigenous-peoples. 
Thelen, Kathleen. 1999. "Historical Institutionalism in Comparative Politics." Annual Review of Political Science 2: 369-404.

Thelen, Kathleen, and Sven Steinmo. 1992. "Historical Institutionalism in Comparative Politics." In Stucturing Politics: Historical Institutionalism in Comparative Analysis, edited by Sven Steinmo, Kathleen Thelen, and Frank Longstreith, 1-32. Cambridge University Press.

Townshend, H.W. Roger. 2017. "What Changes Did Grassy Narrows First Nation Make to Federalism and Other Doctrines?" Canadian Bar Review 95: 459-88.

Tsilhqot'in Nation v. British Columbia. 2014 [2014] 2 SCR 257. Supreme Court of Canada.

Turner, Dale. 2006. This Is Not a Peace Pipe: Towards a Critical Indigenous Philosophy. University of Toronto Press.

Tzimas, E. Ria. 2005. "Haida Nation and Taku River: A Commentary on Aboriginal Consultation and Reconciliation." Supreme Court Law Review 29 (1): 461-84.

_. 2011. "To What End the Dialogue?" Supreme Court Law Review 54: 493-527.

United States of America. 1868. The Constitution of the United States of America. https://www.law.cornell.edu/constitution.

Vipond, Robert C. 1989. "1787 and 1867: The Federal Principle and Canadian Confederation Reconsidered." Canadian Journal of Political Science 22 (1): 3-25.

Walters, Mark D. 1999. "The Golden Thread of Continuity: Aboriginal Customs at Common Law and Under the Constitution Act, 1982." McGill Law Journal 44 (3): 711-52.

. 2006. “The Morality of Aboriginal Law." Queen's Law Journal 31 (2): 470-520.

. 2010. "The Jurisprudence of Reconciliation: Aboriginal Rights in Canada." In The Politics of Reconciliation in Multicultural Societies, edited by Will Kymlicka and Bashir Bashir, 165-91. Oxford University Press.

- 2017. "Rights and Remedies within Common Law and Indigenous Legal Traditions: Can the Covenant Chain Be Judicially Enforced Today?" In The Right Relationship: Reimagining the Implementation of Historical Treaties, edited by John Borrows and Michael Coyle, 187-207. Toronto: University of Toronto Press.

Wedge, Grant. 2018. Assistant Deputy Minister, Negotiations and Reconciliation Division, Ontario Ministry of Indigenous Affairs, in conversation with the author.

Whetung, Emily. 2020. Chief, Curve Lake First Nation, in conversation with the author.

White, Erik. 2020. "Anishinabek Nation Says 8 of 14 First Nations Vote Yes on Governance Agreement, but Turnout Still in Question." CBC News, March 4, 2020.

https://www.cbc.ca/news/canada/sudbury/anishinabek-governance-vote-first-nations-1.5484886.

Williams Jr., Robert A. 1994. "Linking Arms Together: Multicultural Constitutionalism in a North American Indigenous Vision of Law and Peace." California Law Review 82 (4): 981-1049.

Wilson, Shawn. 2008. Research Is Ceremony: Indigenous Research Methods. Fernwood Publishing.

Wolfe, Patrick. 2006. "Settler Colonialism and the Elimination of the Native." Journal of Genocide Research 8 (4): 387-409.

Young, Joan M., Jason J. Annibale, and Brent Ryan. 2014. “Court Affirms Right of Province to ‘Take up' Treaty Lands - Grassy Narrows First Nation v. Ontario (Natural Resources).” McMillan LLP.

Zlotkin, Norman K. 1984. "The 1983 and 1984 Constitutional Conferences: Only the Beginning." Canadian Native Law Reporter 3: 3-29. 
Appendix A: Sections 91 and 92, British North America Act, 1867

91. It shall be lawful for the Queen, by and with the Advice and Consent of the Senate and House of Commons, to make Laws for the Peace, Order, and good Government of Canada, in relation to all Matters not coming within the Classes of Subjects by this Act assigned exclusively to the Legislatures of the Provinces; and for greater Certainty, but not so as to restrict the Generality of the foregoing Terms of this Section, it is hereby declared that (notwithstanding anything in this Act) the exclusive Legislative Authority of the Parliament of Canada extends to all Matters coming within the Classes of Subjects next hereinafter enumerated; that is to say, --

1. The Public Debt and Property.

2. The Regulation of Trade and Commerce.

3. The raising of Money by any Mode or System of Taxation.

4. The borrowing of Money on the Public Credit.

5. Postal Service.

6. The Census and Statistics.

7. Militia, Military and Naval Service, and Defence.

8. The fixing of and providing for the Salaries and Allowances of Civil and other Officers of the Government of Canada.

9. Beacons, Buoys, Lighthouses, and Sable Island.

10. Navigation and Shipping.

11. Quarantine and the Establishment and Maintenance of Marine Hospitals.

12. Sea Coast and Inland Fisheries.

13. Ferries between a Province and any British or Foreign Country or between Two Provinces.

14. Currency and Coinage.

15. Banking, Incorporation of Banks, and the Issue of Paper Money.

16. Savings Banks.

17. Weights and Measures.

18. Bills of Exchange and Promissory Notes.

19. Interest.

20. Legal Tender.

21. Bankruptcy and Insolvency.

22. Patents of Invention and Discovery.

23. Copyrights.

24. Indians, and Lands reserved for the Indians.

25. Naturalization and Aliens.

26. Marriage and Divorce.

27. The Criminal Law, except the Constitution of Courts of Criminal Jurisdiction, but including the Procedure in Criminal Matters.

28. The Establishment, Maintenance, and Management of Penitentiaries.

29. Such Classes of Subjects as are expressly excepted in the Enumeration of the Classes of Subjects by this Act assigned exclusively to the Legislatures of the Provinces.

And any Matter coming within any of the Classes of Subjects enumerated in this Section shall not be deemed to come within the Class of Matters of a local or private Nature comprised in the 
Enumeration of the Classes of Subjects by this Act assigned exclusively to the Legislatures of the Provinces.

92. In each Province the Legislature may exclusively make Laws in relation to Matters coming within the Classes of Subjects next hereinafter enumerated, that is to say,

1. The Amendment from Time to Time, notwithstanding anything in this Act, of the Constitution of the Province, except as regards the Office of Lieutenant Governor.

2. Direct Taxation within the Province in order to the raising of a Revenue for Provincial Purposes.

3. The borrowing of Money on the sole Credit of the Province.

4. The Establishment and Tenure of Provincial Offices and the Appointment and Payment of Provincial Officers.

5. The Management and Sale of the Public Lands belonging to the Province and of the Timber and Wood thereon.

6. The Establishment, Maintenance, and Management of Public and Reformatory Prisons in and for the Province.

7. The Establishment, Maintenance, and Management of Hospitals, Asylums, Charities, and Eleemosynary Institutions in and for the Province, other than Marine Hospitals.

8. Municipal Institutions in the Province.

9. Shop, Saloon, Tavern, Auctioneer, and other Licences in order to the raising of a Revenue for Provincial, Local, or Muni-cipal Purposes.

10. Local Works and Undertakings other than such as are of the following Classes,--

a. Lines of Steam or other Ships, Railways, Canals, Telegraphs, and other

Works and Undertakings connecting the Province with any other or others of the Provinces, or extending beyond the Limits of the Province:

b. Lines of Steam Ships between the Province and any British or Foreign

Country:

c. Such Works as, although wholly situate within the Province, are before or after their Execution declared by the Parliament of Canada to be for the general Advantage of Canada or for the Advantage of Two or more of the Provinces.

11. The Incorporation of Companies with Provincial Objects.

12. The Solemnization of Marriage in the Province.

13. Property and Civil Rights in the Province.

14. The Administration of Justice in the Province, including the Constitution, Maintenance, and Organization of Provincial Courts, both of Civil and of Criminal Jurisdiction, and including Procedure in Civil Matters in those Courts.

15. The Imposition of Punishment by Fine, Penalty, or Imprisonment for enforcing any Law of the Province made in relation to any Matter coming within any of the Classes of Subjects enumerated in this Section.

16. Generally all Matters of a merely local or private Nature in the Province.

(British North America Act 1867b) 


\section{Appendix B: Questionnaires Used in Semi-Structured Interviews}

\section{General Questionnaire, Ontario Public Service}

1) How did this branch come to be? Was there a particular issue the Ministry was reacting to?

2) Tell me about the current consultation work your branch conducts with First Nations. Can you provide some examples?

3) Who conducts these consultations on behalf of the Ministry?

4) Can you provide some examples of changes that were made following consultation with First Nations?

5) How have your First Nation consultation policies changed in the last 10 to 15 years?

6) Have judicial decisions had an influence on your consultation work? How so?

7) Is there training available to members of your branch on the legal context?

8) Has the Truth and Reconciliation Commission affected the work your branch does? How so?

9) What influence does your branch have on the development of consultation policy?

10) Is there a dialogue between your Ministry and others on the issue of First Nation consultations? If so, how does this dialogue work?

11) What is the relationship between your department and the federal government on First Nation issues? Has this relationship changed?

12) What kind of feedback, either positive or negative, have you received from your First Nation stakeholders on consultation policy?

13) Are there any legal cases you are aware of which could potentially affect your work?

\section{General Questionnaire, First Nation Representatives}

1) How would you describe the relationship between your community(/nation) and the Ontario provincial government?

2) Based on your experience, have you witnessed any major changes in the Ontario-First Nation relationship in roughly the last 15 years? 
3) Are there any legal or policy milestones you regard as key to your relationship with the provincial government?

4) Can you provide an example of experiences your community (/nation) has had consulting with the provincial government? Did these consultations produce changes to the project/policy?

5) Have different provincial ministries taken different approaches when it comes to consultation with First Nations?

6) Are there treaty relationships or policies particular to your community (/nation) which might influence consultations with the province?

7) (Where applicable) Your community (/nation) has developed its own consultation policy. Can you describe how this came about? Has the provincial government been receptive to your internal policy?

8) What constructive role could the provincial government play for First Nations in Ontario?

9) Do you think there is a difference in the way the provincial and federal governments conduct consultations?

10) Do you think there are inherent tensions between Indigenous and non-Indigenous ways of governing? How can these tensions be resolved? 


\section{Appendix C: Land Claim Processes in Ontario}

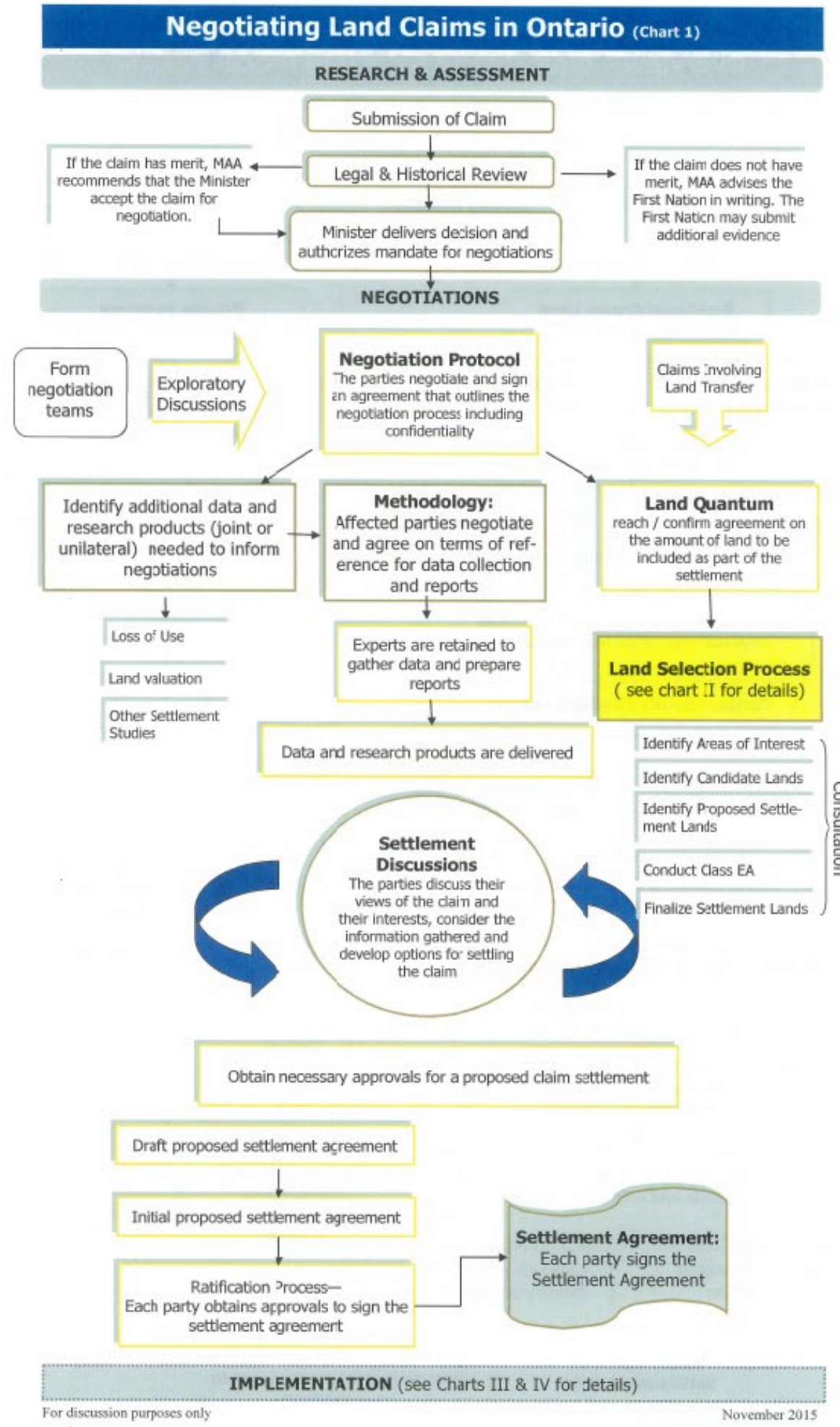




\section{Overview-Typical Land Selection Process (chart II)}

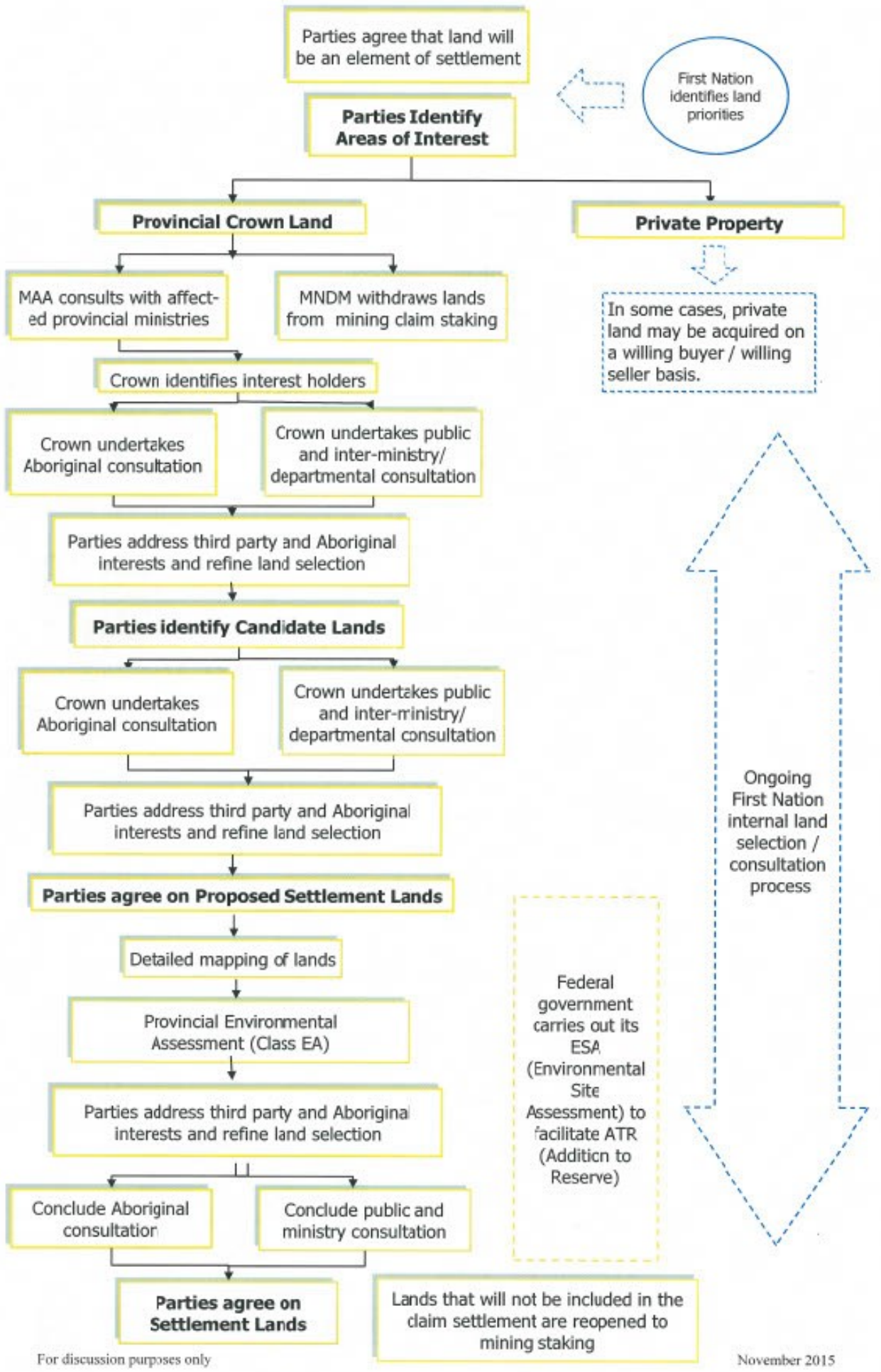




\section{Implementation - Tripartite Agreement (Chart III)}

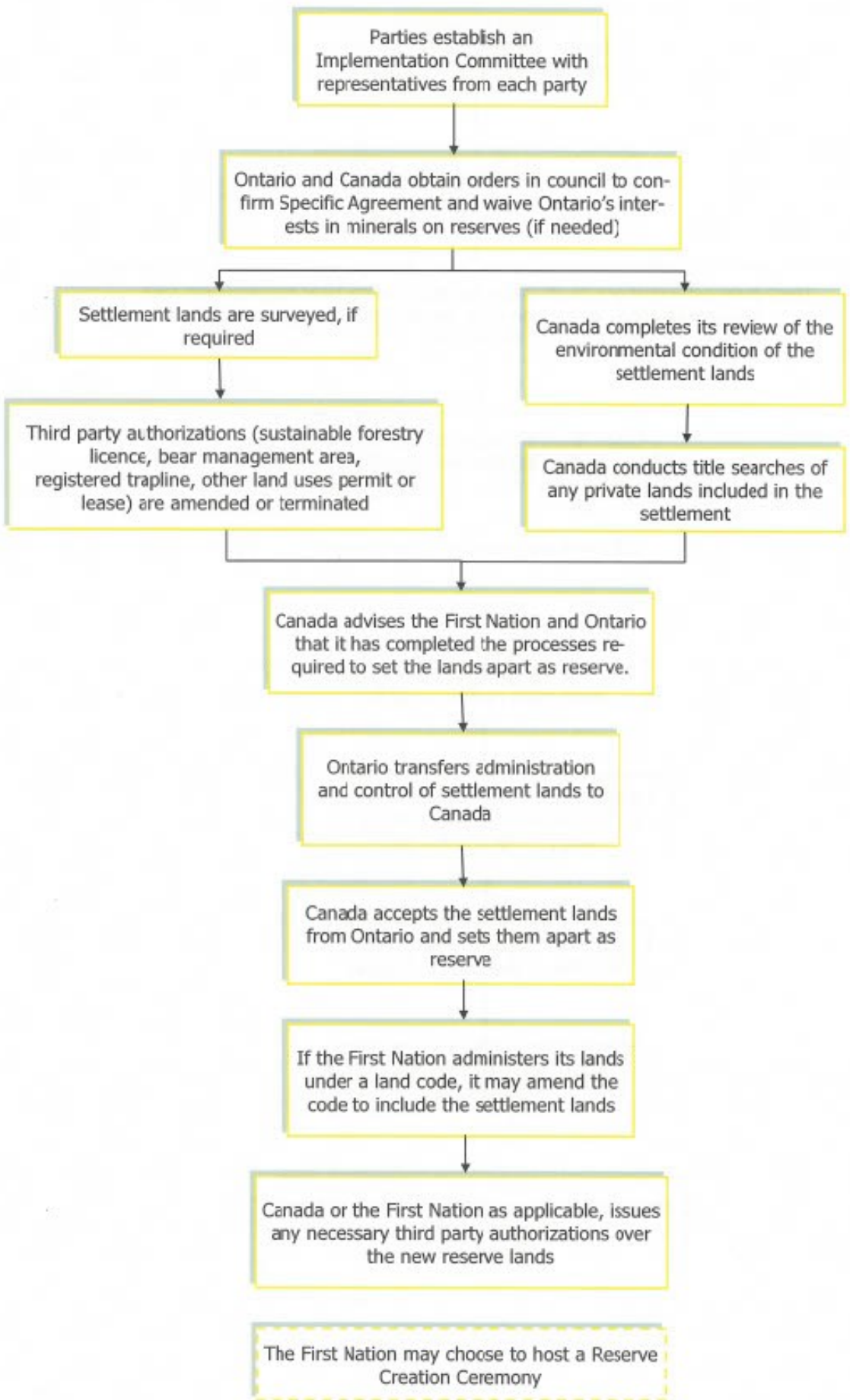




\section{Implementation - Bilateral Agreement (Chart Iv)}

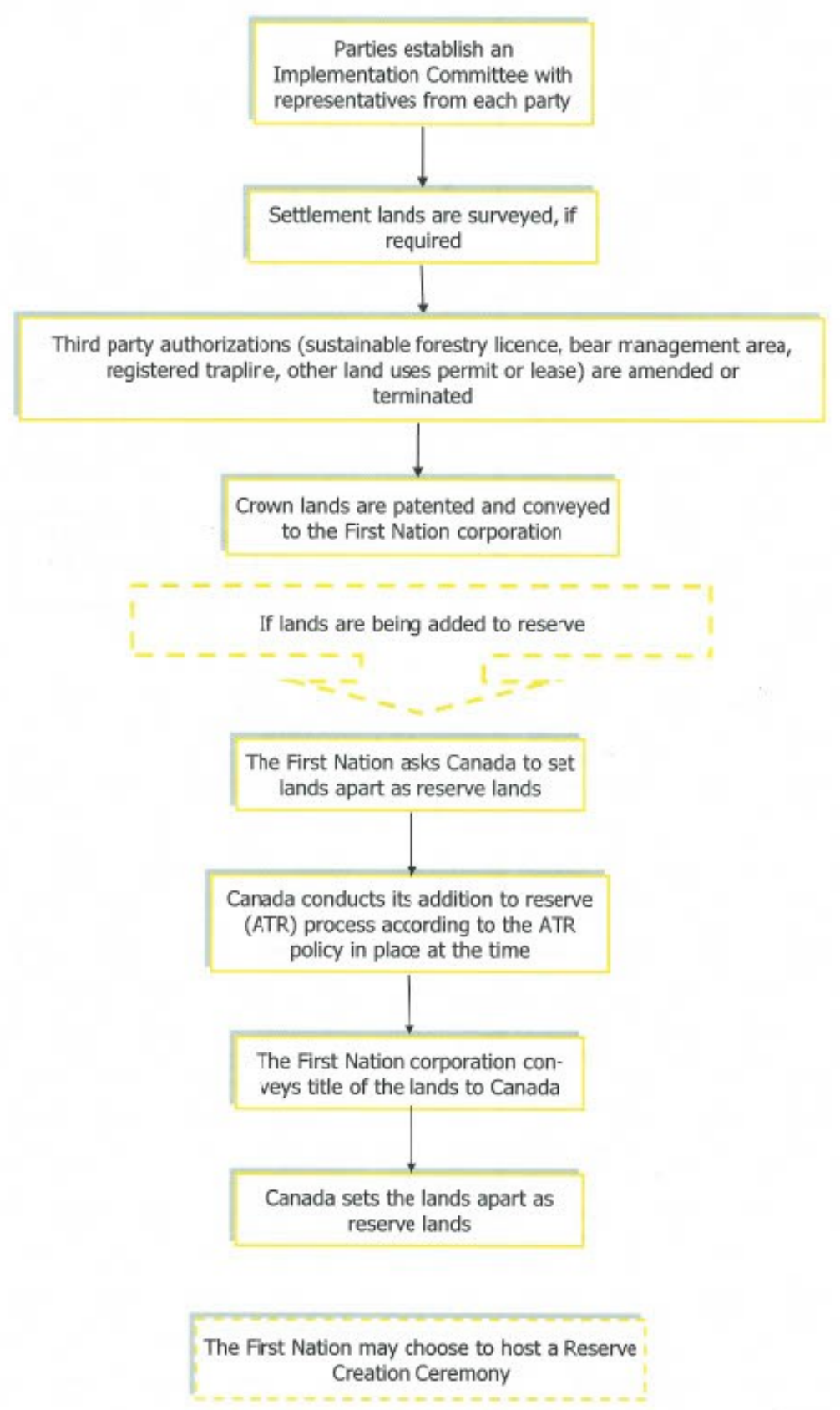




\section{Appendix D: Policy Actors in Ontario Indigenous Policy}

Figure 4: Government and Other Organizations Involved in Providing Indigenous Programs and Services in Ontario Prepared by the Office of the Auditor General of Ontario

Other Ministries

Deliver programs and services to

Indigenous Peoples in areas of provincial responsibility such as health, community and social services, and economic development.

Ministry of Indigenous Affairs Develops and supports Indigenous policy for Ontario. Leads the provincial negotiation of Indigenous land claims.
Indigenous Partners

Organizations such as the Ontario

Federation of Indigenous

Friendship Centres and

Tungasuvvingat Inuit support,

advocate and deliver culturally

enriched programs and services
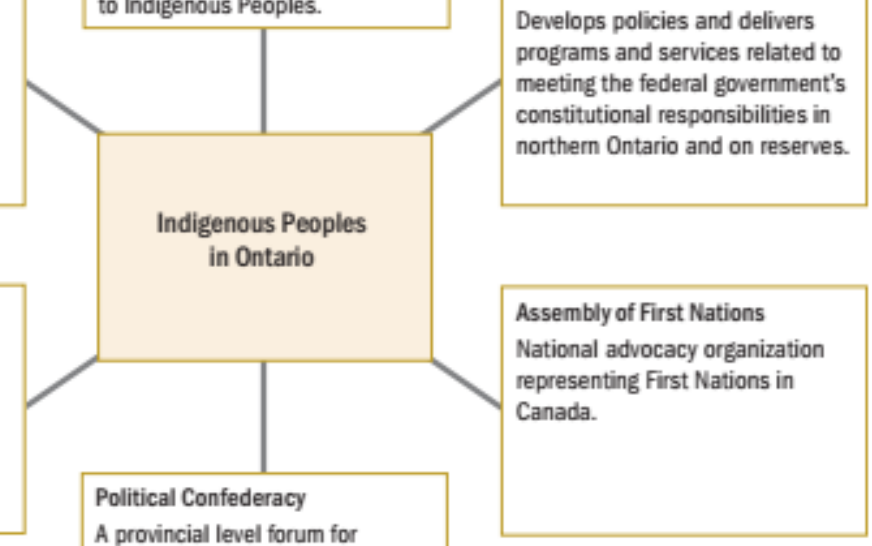

to Indigenous Peoples.

Indigenous Peoples in Ontario

Government of Canada Develops policies and delivers programs and services related to meeting the federal government's constitutional responsibilities in northern Ontario and on reserves.

collective decision-making and advocacy for the 133 First Nations communities. 